\title{
O papel da avaliação de riscos no gerenciamento de produtos agrotóxicos: diretrizes para a formulação de políticas públicas
}

Sérgia de Souza Oliveira

Tese apresentada ao Programa de PósGraduação em Saúde Pública da Faculdade de Saúde Pública da Universidade de São Paulo para obtenção do título de Doutor em Saúde Pública.

Área de Concentração: Saúde Ambiental Orientador: Prof. Dr. Carlos Celso do Amaral e Silva.

São Paulo

2005 
Autorizo, exclusivamente para fins acadêmicos e científicos, a reprodução total ou parcial desta tese, por processo fotocopiadores.

Assinatura:

Data: 
“....o planeta Terra resulta de decisões tomadas pela espécie humana, que tanto podem aprimorar os lugares, enriquecê-los e embelezá-los, como também destruí-los, degradá-los, desertificá-los e empobrecê-los.” (RIBEIRO, 1998, pg.125). 
Aos meus pais, Walter e Terezinha, por serem meus referenciais de vida, e por tudo o que não alcanço expressar em palavras;

Ao meu marido, Itiberê, e meus filhos, Davi e Tiago, pelo amor, compreensão, ajuda e companheirismo, por serem os amores da minha vida e estarem sempre incondicionalmente ao meu lado.

Como todo meu amor, é a vocês que dedico este trabalho. 


\section{AGRADECIMENTOS}

Ao Professor Carlos Celso do Amaral e Silva pelo incentivo e pela confiança depositada no meu trabalho.

Um especial agradecimento à Professora Adelaide Nardocci, do Departamento de Saúde Ambiental, da Faculdade de Saúde Pública, que contribuiu de forma fundamental na elaboração deste trabalho, discutindo e repassando idéias.

Aos colegas de curso, principalmente Nancy e Taís, pelo apoio, estímulo e conselhos. A minha amiga Marluci, pela solidariedade e amizade, fundamentais para o término deste trabalho.

Às excelentes funcionárias da biblioteca da FSP, sem a disposição, simpatia e ajuda de vocês não teria sido possível adquirir grande parte do material bibliográfico.

À minha família! Meu pai, minha mãe, meus irmãos Cláudia, Henrique a Antonio Mário, cunhado e cunhadas e a minha sogra, Da. Heleida. Este agradecimento é especialíssimo! Desculpa pela falta de tempo para me dedicar a vocês, pelos momentos de tensão, desânimo e falta de paciência que vocês tiveram que compartilhar, eu acho impossível agradecer à altura. Vocês sabem que os amo mais do que qualquer coisa. Valeu, e só Deus pode retribuir este carinho.

Ao Itiberê, meu marido, companheiro e amigo, você sabe que esta é mais uma experiência para enriquecer nossa vida e a de nossos amados filhos, Davi e Tiago.

A todos os amigos e colegas de trabalho que sempre contribuíram e me deram forças para realizar deste trabalho, principalmente aqueles que estão lá no Planalto Central. São tantos que é melhor não citar os nomes, mas vocês sabem que todos moram no meu coração. Aos amigos especiais de Piracicaba, que me acolheram com enorme carinho e me ensinaram tanto sobre amizade, eu nunca esquecerei vocês!

Ao Conselho Nacional de Desenvolvimento Científico e Tecnológico - CNPq, pelo apoio financeiro nos dois últimos anos do curso.

A Deus, por ter escutado as minhas preces. Tudo isso é para a Glória do Senhor! 


\section{RESUMO}

Oliveira S.S. O Papel da Avaliação de Riscos no Gerenciamento de Produtos Agrotóxicos: Diretrizes para a Formulação de Políticas Públicas. São Paulo; 2005. [Tese de Doutorado - Faculdade de Saúde Pública da USP].

Objetivo. Fornecer subsídios para a formulação de políticas públicas baseadas na avaliação de riscos, para o gerenciamento de agrotóxicos, tendo como foco de estudo os atuais procedimentos técnicos utilizados em nível federal para registro de produtos agrotóxicos, e as exigências relacionadas à avaliação de riscos presentes em dois acordos internacionais sobre substâncias químicas. Métodos. Consistiu na pesquisa bibliográfica da literatura sobre avaliação de riscos e nos documentos que o governo federal utiliza para gerenciar substâncias químicas. Todo material coletado foi analisado e interpretado a luz do tema enfocado neste trabalho - o uso da avaliação de riscos de substâncias químicas como ferramenta para tomada de decisão em nível governamental Resultados. O gerenciamento das substâncias químicas é descentralizado, sem pauta de ação definida e realizado por meio da individualização dos riscos das substâncias. Pelo menos quatorze instituições federais possuem alguma atuação no gerenciamento. A atuação unilateral da maioria das instituições envolvidas gera uma legislação fragmentada, e implementada sob baixo grau de coordenação. O controle da implementação é feito pelo Estado, por meio da fiscalização dos padrões de emissão definidos, ou pela restrição ou proibição. Apesar de existir um rico arcabouço legal, ele não garante que a sociedade esteja usufruindo benefícios, uma vez que a falta de dados oficiais, e o reduzido número de resultados de investigações científicas relacionados ao tema, dificultam as tentativas de análise. Os principais atores envolvidos no gerenciamento dos agrotóxicos são os ministérios da Saúde, do Meio Ambiente e da Agricultura, que definem a emissão do registro. Outros ministérios possuem atividades de gerenciamento paralelas, como o do Transporte e do Trabalho. O parâmetro para registro é essencialmente a avaliação do potencial de perigo ambiental e toxicológico e a atividade de avaliação de riscos, apesar de ser citada no principal documento legal do setor, não esta implementada ou discutida em bases concretas. Os estudos que orientam a decisão do registro não são divulgados. Para implementar as convenções o país deve modificar o seu referencial de tomada de decisão.Conclusões. (1) As instituições federais brasileiras atuam de 
forma independente e elaboram normas legais para os assuntos sob sua responsabilidade, sendo o Estado o principal responsável pela definição dos parâmetros de proteção. (2) A fragmentação excessiva da legislação sobre substâncias químicas impede definir se a implementação das políticas traz benefícios para a sociedade. (3) a legislação que dá a base para o controle dos agrotóxicos no País é tecnicamente atualizada, mas o gerenciamento efetivamente executado ainda está muito aquém do potencial permitido pela legislação. (4) O conceito científico de risco é ignorado na maioria dos documentos legais para o gerenciamento de substâncias químicas no Brasil. (5) A infra-estrutura legal existente viabiliza a implementação da avaliação de riscos à saúde humana e ao meio ambiente no gerenciamento de agrotóxicos. (6) A infra-estrutura institucional deve migrar para uma perspectiva mais inclusiva e integradora, privilegiando a geração de dados e valores multirreferenciais, se o país quiser utilizar o risco como referência para o gerenciamento de agrotóxicos. (7) Com os atuais procedimentos de tomada de decisão o Brasil não tem as condições de atender às obrigações relacionadas à avaliação de riscos constantes das convenções PIC e POPs.

Descritores: Substâncias químicas. Agrotóxicos. Avaliação de riscos. Gerenciamento de riscos. Políticas públicas. Saúde ambiental. 


\section{SUMMARY}

Oliveira SS. O Papel da Avaliação de Riscos no Gerenciamento de Produtos Agrotóxicos: Diretrizes para a Formulação de Políticas Públicas. [Risk Assessment for the Management of Pesticides: Subsidies for Formulating Public Policies] São Paulo (BR); 2005. [Tese de Doutorado - Faculdade de Saúde Pública da USP].

Objective: The purpose of this work was to provide subsidies for formulating public policies based on risk assessment for pesticide management, focusing on the current national technical procedures for the registration of pesticide products and on the requirements regarding risk assessment of two international agreements on chemical substances. Methods: The methodology comprised bibliographical research on risk assessment and on federal government documents about management of chemical substances. All material collected was analyzed and interpreted considering the topic of this work - the use of assessment risk of chemical substances as a tool for governmental decision taking. Results: Chemical substances management is not centralized, with no defined action guidelines, and is conducted in view of the substances risks individually considered At least fourteen federal institutions work on pesticide management. The unilateral performance of most institutions leads to a fragmented legislation, poorly implemented due to lack of coordination. The State is responsible for implementing the legislation, either supervising the defined emission patterns or restricting and prohibiting them. Despite the existence of legal framework, it does not ensure that society is being benefited, once the lack of official data and the reduced amount of scientific inquiry on the subject make the analysis difficult. The main governmental organs involved in pesticide management are the Health, Environment and Agriculture Ministries, which are also responsible for issuing registration certificates. Other ministries have parallel management activities, as it is the case of the Transport and Work Ministries. The parameters for registration are essentially the evaluation of environmental hazard and toxicological potential, as well as the risk assessment activity. In spite of being quoted in the main management document, the assessment activities are not implemented or discussed on solid basis. The studies guiding the decisions on the registration are not published. In order to 
implement the conventions, the country has to change its reference for decision taking. Conclusions: (1) The Brazilian federal institutions act independently and elaborate legal procedures on subjects under their responsibility, with the State being responsible for the definition of safety parameters. (2) The excessive fragmentation of the legislation on chemical substances obstructs the definition about whether implementing the management policies benefits society or not. (3) The legislation in which pesticide control is based on is technically updated. However, the management performed is far behind the scope of the legislation. (4) The scientific concept of risk is ignored in most legal documents concerning the management of chemical substances in Brazil. (5) The existing legal framework enables the implementation of health and environmental risk assessment related to pesticide management. (6) If the country is to use risk as a reference for pesticide management, its institutional infrastructure should assume a more comprehensive and integrated perspective, promoting the generation of multi referential data and figures. (7) The current decision taking procedures in Brazil do not meet the demands concerning the assessment of risks established by PIC and POPs Conventions.

Key words: Chemical Substances, Pesticides, Risk Assessment, Risk Management, Public Policies, Environmental Health. 


\section{LISTA DE SIGLAS}

ANVISA

ATSDR

CCE

CEE

CEFIC

CETESB

CMMAD

CNUMAD

CONAMA

CONASQ

CTA

ECOSOC

EU / UE

FAO

FIOCRUZ

GHS

IARC

IBAMA
Agência Nacional de Vigilância Sanitária

Agency for Toxic Substances and Disease Registry / Agência de Substâncias Tóxicas e Registro de Doenças dos Estados Unidos

Comissão das Comunidades Européias (braço executivo da $\mathrm{UE})$

Comunidade Econômica Européia

European Chemical Industry Council / Conselho Europeu da Indústria Química

Companhia de Tecnologia de Saneamento Ambiental do Estado de São Paulo

Comissão Mundial sobre Meio Ambiente e Desenvolvimento

Conferência das Nações Unidas sobre o Meio Ambiente e Desenvolvimento

Conselho Nacional de Meio Ambiente

Comissão Nacional de Segurança Química

Comitê Técnico de Assessoramento de Agrotóxicos

Economic and Social Council / Conselho Econômico e Social das Nações Unidas

European Union / União Européia

Food and Agriculture Organization of the United Nations / Organização das Nações Unidas para a Alimentação e Agricultura

Fundação Oswaldo Cruz

Globally Harmonized System for the Classification and Labelling / Sistema Globalmente Harmonizado de Classificação e Rotulagem

International Agency for Research on Câncer / Agência Internacional de Pesquisa sobre o Câncer Instituto Brasileiro do Meio Ambiente e dos Recursos Naturais Renováveis 
IBGE

IFCS

ILO / OIT

IPCS

MAPA

MDIC

MMA

MS

MTE

NAS

NRC

OECD

OMS / WHO

OPAS / OPS

PIC
ONU / UN

Instituto Brasileiro de Geografia e Estatística

Intergovernmental Forum on Chemical Safety / Fórum Intergovernamental sobre Segurança Química

International Labour Organization / Organização das Nações Unidas para o Trabalho

International Program on Chemical Safety / Programa Internacional sobre Segurança Química

Ministério da Agricultura, Pecuária e Abastecimento.

Ministério do Desenvolvimento, Indústria e Comércio Exterior.

Ministério do Meio Ambiente

Ministério da Saúde

Ministério do Trabalho e Emprego

National Academy of Sciences / Academia Nacional de Ciências (Estados Unidos)

National Research Council / Conselho da Academia Nacional de Ciências (Estados Unidos)

Organization for Economic Co-Operation and Development / Organização de Cooperação e de Desenvolvimento Econômico Organização Mundial da Saúde / World Health Organization Organizações das Nações Unidas / United Nations

Organização Pan-americana da Saúde / Organización Panamericana de la Salud.

Rotterdam Convention on the Prior Informed Consent Procedure for Certain Hazardous Chemicals and Pesticides in International Trade / Consentimento Prévio Informado

PNUMA / UNEP Programa das Nações Unidas para o Meio Ambiente / United Nations Environmental Program

POPS Poluentes Orgânicos Persistentes

PRONASQ Programa Nacional de Segurança Química

SIA

Sistema de Informações sobre Agrotóxicos

SINDAG
Sindicato Nacional da Indústria de Produtos para Defesa 
Agrícola

SINITOX

SRA

UNITAR

USEPA

WSSD
Sistema Nacional de Informações Tóxico-Farmacológicas

Society for Risk Analysis / Sociedade para Análise de Riscos

United Nations Institute for Training and Research / Instituto das Nações Unidas para Treinamento e Pesquisa

United States Environmental Protection Agency / Agência de Proteção Ambiental dos Estados Unidos

World Summit on Sustainable Development / Cúpula Mundial sobre o Desenvolvimento Sustentável 


\section{ÍNDICE}

1.1. Definição do Problema 9

$\begin{array}{lll}\text { 1.2. } & \text { Estrutura do Trabalho }\end{array}$

$\begin{array}{lll}2 & \text { OBJETIVOS } & 14\end{array}$

$\begin{array}{lll}\text { 2.1. Objetivo Geral } & 14\end{array}$

$\begin{array}{ll}\text { 2.2. Objetivos Específicos } & 14\end{array}$

3 METODOLOGIA 15

$4 \quad$ POLÍTICAS PÚBLICAS $\quad 18$

4.1. Formação de Políticas Públicas 20

4.2. Regulação 25

$5 \quad$ INDÚSTRIA QUÍMICA BRASILEIRA 28

5.1. A Indústria de Agrotóxicos no Brasil 32

$6 \quad$ ASPECTOS INSTITUCIONAIS E LEGISLATIVOS 38

6.1. Panorama Institucional Federal Relacionado às Substâncias $\begin{array}{ll}\text { Químicas } & 40\end{array}$

6.2. Legislação Federal sobre Substâncias Químicas 46

6.3. Legislação Federal sobre Agrotóxicos 56

$7 \quad$ AVALIAÇÃO DE RISCO $\quad 89$

7.1. O Conceito de Risco 89

7.2. O Processo de Avaliação de Risco (AR) 94

7.3. Avaliação de Riscos de Substâncias Químicas 97

$\begin{array}{ll}\text { 7.4. Gerenciamento de Substâncias Químicas } & 108\end{array}$

$\begin{array}{ll}\text { 7.5. Gerenciamento de Agrotóxicos } & 113\end{array}$

7.6. Gerenciamento de Riscos de Agrotóxicos nos Estados Unidos 120

7.7. Gerenciamento de Riscos de Agrotóxicos na União Européia 124 
7.8. Gerenciamento de Riscos de Agrotóxicos no Brasil

8.1. Avaliação de Risco no Contexto das Convenções

9.1.

Agrotóxicos 165

9.2. Implementação das Convenções no Brasil 170

9.3. Recomendações Finais 174

10

REFERÊNCIAS 175

11 ANEXOS 205

11.1

Anexo I 206

11.2. Anexo II 210 


\section{LISTA DE TABELAS}

TABELA 1. Os dez agrotóxicos com maior volume de consumo, em 2000, no Brasil.

TABELA 2. Dados do número total de casos de intoxicações com agrotóxicos de uso agrícola, no Brasil, no período de $1997-$ 2001, segundo dados do SINITOX.

TABELA 3. Agrotóxicos com restrições, ou proibidos, no país

TABELA 4. Sumário das responsabilidades das instituições federais brasileiras, envolvidas no gerenciamento de substâncias químicas.

TABELA 5. Legislação Federal sobre Substâncias Químicas - exceto Agrotóxicos

TABELA 6. Legislação Federal Relacionada a Agrotóxicos 


\section{LISTA DE FIGURAS}

FIGURA 1 Uso de agrotóxicos (kg/ha) e área plantada (ha) para vários Estados brasileiros, no ano de 2001.

FIGURA 2 Número de agrotóxicos comercializados no Brasil, por classe toxicológica, no período de 1992-2002.

FIGURA 3 Síntese do processo de registro de agrotóxicos de acordo com a Lei $7.802 / 89$ e o Decreto $98.816 / 90$

FIGURA 4 Etapas da avaliação de risco, baseada na proposta do NRC (1983)

FIGURA 5 Etapas da exposição, absorção, distribuição, depósito e excreção de uma substância química no organismo humano.

FIGURA 6 Etapa de um sistema de gerenciamento de riscos para substâncias químicas.

FIGURA 7 Introdução dos agrotóxicos nos compartimentos ambientais, a partir do uso e possíveis processos de transformação que podem sofrer e possíveis receptores.

FIGURA 8 Representação esquemática das possíveis rotas de exposição humana aos agrotóxicos.

FIGURA 9 Etapas do gerenciamento pós-registro de agrotóxicos, no Brasil. 


\section{INTRODUÇÃO}

Tem sido observado, nos últimos anos, um acentuado aumento dos estudos voltados para um melhor entendimento das relações entre as alterações na qualidade do meio ambiente e as conseqüências para a saúde humana.

Estas questões são complexas, tanto pela sua natureza quanto pela diversidade de suas causas. As soluções que demandam incluem aspectos de saúde pública, meio ambiente e economia, envolvendo tanto o setor público quanto o privado.

As relações entre saúde e ambiente vêm sendo estudadas e geridas sob numerosas denominações (LIEBER e ROMANO-LIEBER, 2003), como por exemplo - higiene do meio, saneamento ambiental, proteção e desenvolvimento do ambiente, saúde e ambiente, ambiente e saúde, mas que na verdade significam basicamente a mesma coisa (ORDÓÑEZ, 2000).

Inicialmente, para a OMS - Organização Mundial da Saúde, saúde ambiental se restringia aos aspectos da saúde humana e da doença determinados por fatores ambientais. Entretanto, o conceito atualmente utilizado inclui tanto os efeitos patológicos diretos dos produtos químicos, da radiação e de alguns agentes biológicos, como aos efeitos freqüentemente indiretos na saúde e no bem-estar. Efeitos estes decorrentes do ambiente físico, psicológico, social e estético, incluindo a habitação, o desenvolvimento urbano, o uso do solo e o transporte (WHO Europe, 2003).

Desta forma, o termo saúde ambiental deve representar não apenas os efeitos causados pelos aspectos sólidos, líquidos e gasosos do meio ambiente, mas pela totalidade do mundo físico que rodeia o homem, inclusive os outros homens e suas inter-relações (ORDÓÑEZ, 2000).

Em virtude da amplitude do significado do termo "saúde ambiental", torna-se um desafio prover a sociedade em geral com serviços eficientes e efetivos de saúde e proteção ambiental. Considerando, entre outros fatores, a necessidade de pessoal qualificado, apoio administrativo, pesquisa científica impecável e a existência de informações e dados que permitam mensurar e entender os problemas (GORDON, 1996). Serviços esses que devem ser baseados em princípios científicos associados a 
uma racional política pública e privada e a um arcabouço legal pertinente. Além disso, é necessária a priorização, em nível financeiro, para a definição de recursos que viabilizem a implementação das soluções dos problemas identificados a partir de estudos epidemiológicos e avaliações toxicológicas e ambientais dos riscos.

Segundo ORDÓÑEZ (2000), o primeiro passo para lidar com problemas de saúde ambiental é definir quais são estes problemas. Esta etapa é considerada uma atividade complexa devido à dificuldade em se delimitar de forma clara o escopo do termo, optando-se, na maioria dos casos, por construir uma lista extensa de problemas, o que torna extremamente difícil a identificação daqueles prioritários.

Dentre estes problemas insere-se a produção maciça das substâncias químicas e o seu uso intenso, e por vezes indiscriminado, causando graves conseqüências para a saúde humana e o meio ambiente.

As atividades relacionadas à indústria química são essenciais para a sociedade moderna, mas elas podem representar uma ameaça à saúde humana e ao meio ambiente, uma vez que, ao mesmo tempo em que elas propiciam grandes progressos, também criam impactos negativos, principalmente devido aos processos de produção e ao uso inadequado dos produtos (IPCS/UNITAR, 1998).

Nas últimas décadas, têm-se presenciado um significativo crescimento do número de produtos químicos manufaturados e de atividades antrópicas que resultam na liberação de poluentes tóxicos. As substâncias químicas estão presentes em todos os produtos utilizados pelo homem, desde os do setor agrícola, onde são utilizados para a proteção de culturas contra pragas, aos do setor da saúde pública, em produtos destinados à prevenção e cura de doenças nos seres humanos. O que faz da indústria química um dos maiores negócios do mundo (BROWN, 2003).

Segundo dados do Programa Internacional de Segurança Química - IPCS (sigla em inglês), da OMS, a cada ano chegam ao mercado cerca de mil a dois mil novos produtos químicos (PORTO e FREITAS, 1997). A produção mundial de todos os tipos de produtos químicos deve exceder algumas centenas de milhares de toneladas por ano (FREITAS et al. 2002) e, a indústria química norte americana produz anualmente cerca de mil novos compostos totalmente estranhos aos ecossistemas e 
ao organismo humano, que são destinados à fabricação de aditivos alimentares, fibras sintéticas, plásticos, medicamentos e agrotóxicos (CARNEIRO, 2001).

Desde a década de 70 , as mais importantes tendências da indústria química mundial foram o rápido crescimento e o aumento do comércio internacional gerado pelo desenvolvimento tecnológico de processos e produtos. Em 1970, a produção da indústria química mundial era de US\$ 171 bilhões enquanto que, em 1998, a produção foi de US\$ 1.503 bilhões. As projeções realizadas pelas associações norte americana e britânica da indústria química prevêem que, em 2010, a produção da indústria química atingirá US\$ 2.360 bilhões (OECD, 2001).

A comercialização de substâncias orgânicas, em nível mundial, passou de sete milhões de toneladas em 1950, para 63 milhões em 1970, 250 milhões em 1985 e 300 milhões em 1990 (KORTE e COULSTON, 1994).

O Conselho Europeu da Indústria Química (CEFIC, sigla em inglês) afirma que em 1999, as vendas mundiais de substâncias químicas totalizaram US\$ 1,6 trilhões, sendo que a União Européia foi responsável por 29\% deste total (BROWN, 2003).

Apesar da indústria química ser disseminada em todo o mundo, em torno de $80 \%$ do faturamento líquido total se concentra em apenas 16 países, que são, em ordem decrescente de faturamento: Estados Unidos, Japão, Alemanha, China, França, Reino Unido, Itália, Coréia, Brasil, Bélgica / Luxemburgo, Espanha, Holanda, Taiwan, Suécia e Rússia (OECD, 2001).

A América Latina é a segunda região em importância entre os países em desenvolvimento, no que diz respeito ao comércio de produtos químicos. Os maiores produtores da região são o Brasil, o México e a Argentina, seguidos por produtores menores como Colômbia e Venezuela (FREITAS e ARCURI, 1998).

Em termos de faturamento líquido, a indústria química brasileira está classificada como a nona maior do mundo. Ela participa com $3 \%$ do PIB $^{1}$ total do País e $12,5 \%$ do PIB da indústria de transformação, considerando-se toda a matriz industrial. O faturamento líquido da indústria química brasileira, em 2002, considerando todos os

1 PIB = Produto Interno Bruto. É o principal indicador da atividade econômica, exprime o valor da produção realizada dentro das fronteiras geográficas de um país, num determinado período. 
segmentos, atingiu US\$ 36,6 bilhões (ABIQUIM, 2002) e, em 2003 o faturamento chegou a US\$ 45,3 bilhões (ABIQUIM, 2004).

Este cenário coloca a indústria química brasileira em um elevado patamar de importância e alerta para a necessidade de uma discussão mais profunda dos mecanismos de gerenciamento das substâncias químicas. Nos últimos 50 anos, substâncias químicas, antes denominadas inertes ou inofensivas para os seres humanos, passaram a serem consideradas carcinogênicas (p.ex. asbestos/amianto) ou fetotóxicas (p.ex. talidomida), e vários compostos mostraram ser mutagênicos ou carcinogênicos, em estudos com animais (UNEP/IPCS 1999).

Nos últimos anos, a sociedade tem estado cada vez mais preocupada com o uso intensivo de produtos químicos e seus efeitos para o homem e o ambiente natural. Alguns agentes químicos têm causado danos graves à saúde humana e aos ecossistemas, provocando mortes prematuras e efeitos irreversíveis (HACON, 2003). Segundo a autora, dados recentes mostram que vários produtos químicos, principalmente agentes organoclorados, têm sido identificados como causadores de efeitos nos sistemas reprodutivo e endócrino de mamíferos, com aumento significativo da incidência de algumas doenças, como câncer de testículos em homens jovens e alergias, atribuídas à exposição do homem a contaminantes ambientais.

Este quadro é agravado quando se verifica que muitos dos novos compostos e misturas, que têm sido utilizados em todo o mundo, não possuem estudos relacionados à suas propriedades toxicológicas, fazendo com que possíveis impactos negativos, decorrentes do uso destas substâncias químicas, sejam desconhecidos (UNITAR, 1999; CCE, 2004).

A rápida expansão do mercado dos produtos químicos e o insuficiente conhecimento sobre os seus riscos, aliados ao fato de que são poucas as ferramentas eficientes para a tomada de decisão sobre o tema, clamam por uma política pública mais objetiva no trato da questão. No contrário, o quadro de contaminação humana e ambiental tenderá a agravar-se!

Desde de 1960, várias iniciativas internacionais têm sido desenvolvidas com o intuito de avaliar e gerenciar os riscos ao ser humano e aos sistemas naturais 
(IPCS/UNITAR, 1998). Nestas últimas décadas, o desenvolvimento de ferramentas que permitam identificar quali-quantitativamente os riscos químicos, físicos e biológicos tornou-se prioridade internacional (HACON, 2003).

A Conferência das Nações Unidas sobre o Meio Ambiente Humano, realizada em Estocolmo em 1972, é um marco desta discussão. Nela foi redigido e aprovado o Princípio 18 da Declaração sobre o Meio Ambiente Humano, que considera fundamental a contribuição da ciência e da tecnologia para identificar, evitar e controlar os riscos ambientais, e solucionar problemas que ameaçam o meio ambiente e a sociedade (UNEP, 1972). A Conferência de Estocolmo, como é conhecida, destacou a importância do gerenciamento dos produtos químicos, bem como a avaliação dos seus riscos potenciais para a saúde humana e o meio ambiente.

Em 1987, foi aprovado pela ONU o relatório "Nosso Futuro Comum", mais conhecido como "Relatório Brundtland", elaborado pela Comissão Mundial sobre o Meio Ambiente e o Desenvolvimento - CMMAD, criada pelas Nações Unidas e presidida por Gro Brundtland, primeira-ministra da Noruega. O relatório Brundtland faz uma crítica do modelo de desenvolvimento adotado pelos países industrializados e reproduzido nos países em desenvolvimento, ressaltando a incompatibilidade entre os padrões de produção e de consumo e o uso racional dos recursos naturais e a capacidade de suporte dos ecossistemas. Este relatório introduziu o conceito de desenvolvimento sustentável como sendo aquele que atende às necessidades da geração presente sem comprometer a possibilidade das gerações futuras de atenderem a suas próprias necessidades (CMMAD, 1988).

Com a perspectiva de fomentar o desenvolvimento sustentável, a Conferência das Nações Unidas sobre o Meio Ambiente e Desenvolvimento - CNUMAD/92, ocorrida no Rio de Janeiro, em 1992, aprovou o documento denominado Agenda 21. Esta agenda apresenta nos seus 40 capítulos, orientações, caminhos e princípios a serem seguidos pelos governos e outros atores sociais na busca de uma sociedade mais justa e ecologicamente equilibrada. Os perigos representados pelos produtos químicos são abordados em sete capítulos da Agenda 21, sendo que o capítulo de número 19 trata especificamente do manejo ecológico das substâncias químicas, incluindo a prevenção do tráfico de produtos tóxicos e perigosos. 
$\mathrm{Na}$ introdução do Capítulo 19 é afirmado que "a utilização substancial de produtos químicos é essencial para alcançar os objetivos sociais e econômicos da comunidade mundial $e$ as melhores práticas modernas demonstram que eles podem ser amplamente utilizados com boa relação custo-eficiência e com alto grau de segurança. Entretanto, ainda resta muito a fazer para assegurar o manejo ecologicamente saudável das substâncias químicas tóxicas dentro dos princípios de desenvolvimento sustentável e de melhoria da qualidade de vida da humanidade" (CNUMAD, 2001; pg. 375).

Neste sentido, são propostas seis áreas programáticas para garantir o gerenciamento ecologicamente racional dos produtos químicos:

- ampliação e aceleração das providências para a avaliação dos riscos de origem química, em nível internacional;

- harmonização dos critérios de classificação e rotulagem de produtos químicos;

- intercâmbio de informações sobre produtos químicos tóxicos e riscos de origem química;

- implantação de programas de redução de riscos;

- fortalecimento institucional e capacitação, em nível de país, para o manejo de produtos químicos;

- prevenção do tráfico ilegal de produtos tóxicos e perigosos.

A Declaração do Rio, também aprovada na CNUMAD/92, propõe, no seu artigo 15, o princípio da precaução, o qual vem sendo utilizado para a promoção da segurança química, e estabelece que "a ausência de absoluta certeza científica não deve ser utilizada como razão para postergar medidas eficazes e economicamente viáveis para prevenir a degradação ambiental” (UN, 1992; pg.3).

A aplicação deste princípio tem suscitado grandes discussões e tem sido tema recorrente nos estudos relacionados à segurança química (UN, 2002) e ao direito ambiental internacional (LEITE e AYALA, 2002). 
Com a finalidade de efetivar e coordenar as iniciativas internacionais relacionadas à gestão de substâncias química, citadas no capítulo 19 da Agenda 21, em 1994, foi criado o Fórum Intergovernamental sobre Segurança Química - IFCS (sigla em inglês), como um mecanismo interorganizacional, no âmbito das Organizações das Nações Unidas, envolvendo a participação de 156 países. O IFCS procura fomentar, tanto por meio de apoio financeiro como logístico, a participação dos países menos desenvolvidos nas discussões que ocorrem em nível internacional (IFCS, 2002).

Para o IFCS, o termo segurança química significa a ação preventiva contra os efeitos adversos de curto e longo prazo, para o ser humano e o meio ambiente, decorrentes da produção, estocagem, transporte, uso e disposição de substâncias químicas (IFCS 2002).

O IFCS elaborou e mantêm em processo de revisão, sugestões sobre ações consideradas prioritárias em nível internacional para a promoção da segurança química, no documento denominado "Priorities for Action Beyond 2000" (IFCS, 2002), traduzido para o português como "Prioridades de ação para após o ano 2000".

Nesta mesma linha, uma importante e recente ação internacional promovida pela ONU, foi a Reunião da Cúpula Mundial sobre o Desenvolvimento Sustentável WSSD (sigla em inglês), ocorrida em 2002, em Joanesburgo, África do Sul (UN, 2002). Nesta reunião foi adotado o "Plano de Implementação da Cúpula", que relaciona atividades que visam acelerar o cumprimento dos objetivos definidos na CNUMAD/92 em diversas áreas, dentre elas, a de gerenciamento de substâncias químicas (UN, 2002, p.19).

As substâncias químicas são abordadas no Capítulo III do Plano de Implementação, que trata da "Alteração dos padrões insustentáveis de produção e consumo", parágrafos 22 (resíduos e seu gerenciamento) e 23 (gerenciamento das substâncias químicas no seu ciclo de vida).

O Parágrafo 22 ressalta a necessidade de desenvolver sistemas de gerenciamento de resíduos, com alta prioridade para os sistemas de prevenção e minimização, reúso e reciclagem, sistemas de disposição adequada e de geração de energia a partir de resíduos, iniciativas de reciclagem de pequena escala. Destaca também a prevenção e 
a minimização de impactos por meio do incentivo ao consumo de produtos reutilizáveis ou biodegradáveis.

O parágrafo 23 coloca que o gerenciamento dos produtos químicos durante o ciclo de vida, assim como os resíduos perigosos, devem contribuir, entre outras coisas, para o desenvolvimento sustentável e a proteção da saúde humana e do meio ambiente e estabelece que, até o ano de 2020, os “.... produtos químicos devem ser utilizados $e$ produzidos de uma forma que leve à redução dos efeitos adversos significativos sobre a saúde humana e o meio ambiente, utilizando procedimentos científicos transparentes de avaliação de risco, e procedimentos científicos de gerenciamento de riscos, levando em conta o princípio da precaução estabelecido no artigo 15 , da Declaração do Rio sobre Meio Ambiente e Desenvolvimento ....” (UN, 2002, p.19) .

Neste Parágrafo 23 são apresentadas sete ações que deverão prioritariamente ser realizadas pelos países, dentre elas, vale destacar a ratificação e implementação das convenções internacionais sobre substâncias químicas, especificamente a "Convenção sobre o Procedimento de Consentimento Prévio Fundamentado, Aplicável a certos Agrotóxicos e Produtos Químicos Perigosos Objeto de Comércio Internacional" - Convenção de Roterdã ou PIC, e a "Convenção de Estocolmo sobre Poluentes Orgânicos Persistentes" - Convenção de Estocolmo ou POPs.

No Parágrafo 109, relacionado aos meios de implementação, o plano cita que é necessário "melhorar a formulação de políticas e a tomada de decisões em todos os níveis, mediante, por exemplo, maior colaboração entre cientistas das áreas das ciências naturais e das ciências sociais, bem como entre cientistas e os responsáveis pela elaboração de políticas" (UN, 2002, p. 59) e, como umas das sugestões para que isto ocorra, o Plano sugere que se recorra "com maior freqüência às avaliações científicas integradas, às avaliações de risco e às abordagens interdisciplinares $e$ intersetoriais" (UN, 2002, p. 59).

Desta forma, este trabalho insere-se em um momento de intensa discussão, de rápidas mudanças e de grandes demandas, seja em nível nacional ou internacional, de busca e consolidação de ferramentas mais efetivas para o gerenciamento adequado das substâncias químicas. Neste contexto, ele buscará entre outros, contribuir para 
uma reflexão mais crítica das questões relativas ao gerenciamento de agrotóxicos no âmbito do Brasil.

\subsection{Definição do Problema}

O processo de tomada de decisão nas questões que envolvem a avaliação de riscos é bastante complexo e, de forma geral, não existem procedimentos padronizados para a condução das avaliações de riscos de substâncias químicas. Usualmente é viabilizada pela utilização de princípios de ecotoxicologia para a quantificação e a qualificação da ação de substâncias químicas potencialmente perigosas sobre os organismos vivos; pela análise dos fatores sócio-econômicos e, pelos dados de monitoramento dos aspectos relacionados à saúde e ao meio ambiente, os quais são utilizados para a obtenção de informações relacionadas à exposição e à análise do risco-benefício do uso das substâncias.

No Brasil, a discussão sobre riscos ainda é bastante limitada e restrita a pequenos grupos, com pouco debate a respeito das suas vantagens e implicações sociais, políticas e éticas, bem como a eficácia do uso do conceito de risco como um critério orientador ou determinante na tomada de decisão (NARDOCCI, 1999).

A maioria dos estudos com substâncias químicas realizados no país aborda contaminações específicas (humana ou meio ambiente), avaliadas de forma isolada, sem considerar a multiplicidade de rotas de exposição e a variabilidade de causas do problema. O procedimento atualmente utilizado para registro de agrotóxicos no Brasil, por exemplo, é bastante complexo e burocrático, e exige controles ambientais e toxicológicos rigorosos, entretanto a avaliação de riscos ainda não tem sido utilizada.

Considerando a importância da indústria química brasileira no cenário nacional e internacional, e as exigências por procedimentos transparentes para a avaliação dos efeitos das substâncias químicas, é fundamental discutir como o País tem elaborado as políticas públicas neste setor bem como, sobre as possibilidades de utilização da avaliação de riscos à saúde humana e ao meio ambiente como uma ferramenta para subsidiar decisões de gerenciamento visando à redução dos riscos destas substâncias. 
Deste modo, além de uma visão geral das políticas públicas relacionadas à produção e ao uso de substâncias químicas, é discutido neste trabalho como a legislação federal para registro de produtos agrotóxicos atualmente em vigor no Brasil considera a avaliação de riscos à saúde humana e ao meio ambiente e se, como tal, viabiliza a formulação de uma política nacional consistente e integrada sobre o assunto.

A principal questão considerada são os mecanismos de avaliação para tomada de decisão sobre o uso de agrotóxicos, em nível governamental federal. Além disso, é feita uma abordagem paralela sobre as convenções internacionais no campo da promoção da segurança química, as quais têm estimulado muitos países a elaborar instrumentos regulatórios com o objetivo de proteger tanto os trabalhadores como a população e o meio ambiente (UNEP/IPCS 1999).

É reconhecido que, entre as causas para o surgimento do grande número de normas legais relacionadas às substâncias químicas está o aumento da consciência por parte da sociedade em geral e o crescimento do mercado destas substâncias. Este fato levou ao aumento do interesse sobre o controle dos usos, sobretudo daquelas substâncias que claramente oferecem riscos à saúde humana e ao meio ambiente, como é o caso dos agrotóxicos, um grave problema a ser gerenciado em muitos países.

Estima-se que, anualmente, três milhões de pessoas sejam contaminadas por agrotóxicos em todo o mundo, sendo que $70 \%$ desses casos ocorrem nos países em desenvolvimento (WHO, 1985). Regiões como África, América Latina e Ásia são citadas como locais onde não existe infra-estrutura suficiente para regular e controlar eficazmente o uso de agrotóxicos (NUNES e RIBEIRO, 1999).

O Brasil está entre os quatro países com maior consumo de agrotóxicos no mundo, sendo estimado em 2,5 a 3 milhões de toneladas por ano (MOREIRA et al. 2002). Segundo o Ministério da Agricultura, Pecuária e Abastecimento - MAPA, a comercialização de agrotóxicos no Brasil, em 2001, movimentou 2,29 bilhões de dólares (MAPA, 2004).

São vários os exemplos de iniciativas internacionais, voltadas para uso seguro dos agrotóxicos, principalmente no âmbito das organizações intergovernamentais das 
Nações Unidas. A Organização Mundial de Saúde (OMS), a Organização das Nações Unidas para Alimentação e Agricultura (FAO, sigla em inglês) e o Programa das Nações Unidas para o Meio Ambiente - PNUMA preocupam-se principalmente com os países que não possuem a infra-estrutura necessária nem a assistência adequada de especialistas, para garantir o uso seguro das substâncias químicas perigosas (UNITAR, 1999; FAO, 2004; UNEP, 2004).

Estas ações têm gerado, no âmbito intergovernamental, a elaboração de convênios multilaterais, também chamados de convenções, voltados especificamente para o manejo adequado de substâncias químicas, incluindo os agrotóxicos. Estas convenções, depois de ratificadas pelos países, tornam-se instrumentos legais mandatários, impondo obrigações tanto de ordem técnica como econômica e social.

Neste ano de 2004 passaram a vigorar duas convenções internacionais sobre substâncias químicas, que abordam de forma significativa os agrotóxicos: a "Convenção sobre o Procedimento de Consentimento Prévio Fundamentado Aplicável a certos Agrotóxicos e Produtos Químicos Perigosos Objeto de Comércio Internacional" - Convenção de Roterdã ou Convenção PIC; e a "Convenção de Estocolmo sobre Poluentes Orgânicos Persistentes” - Convenção POPs.

Estas duas convenções estabelecem os procedimentos para o controle do comércio internacional (Convenção PIC) e para o controle ou total eliminação (Convenção POPs) das substâncias listadas em seus textos, além de definir mecanismos e critérios para a inclusão de novas substâncias, com critérios definidos. Segundo o texto das Convenções, a inclusão de uma substância, ou a tomada de decisão sobre determinada substância, no âmbito da Convenção, deve considerar, preferencialmente, estudos sobre os riscos da substância. Desta forma, a participação efetiva de um país nos processos decisórios no âmbito destes convênios dependerá da capacidade deste de identificar, avaliar e gerenciar os riscos.

É discutida neste trabalho a implementação destas Convenções, confrontando os procedimentos utilizados no Brasil e as exigências previstas nos acordos internacionais PIC e POPS, relacionadas à avaliação de riscos, a fim de contribuir para que o País possa participar de maneira mais efetiva deste processo decisório e, 
portanto, gerenciar de maneira adequada os riscos relacionados aos produtos agrotóxicos.

Esta pesquisa enfatiza a discussão sobre a viabilidade da utilização da avaliação de riscos de agrotóxicos para auxiliar a tomada de decisão em nível federal, especificando as condições exigíveis para uma atuação mais efetiva, além da discussão sobre a eficácia desta ferramenta, no contexto nacional.

\subsection{Estrutura do Trabalho}

Para iniciar a construção do referencial teórico, optou-se por se destacar as bases sobre as quais devem ser elaboradas as políticas públicas, abordando conceitos e o processo de sua formulação.

Para demonstrar a importância do tema para o país, foi elaborada uma descrição geral da indústria química brasileira e a dos agrotóxicos, incluindo a produção, o uso e o registro de intoxicações.

No que pode ser considerado o capítulo central do trabalho, é analisada, em um sentido descritivo, a história legislativa brasileira relacionada às substâncias químicas, culminando com uma análise do estado atual da implementação da legislação.

Em continuação, na análise da legislação de agrotóxicos são apresentados os procedimentos utilizados ao longo da história legislativa pelas instituições federais, para tomada de decisão sobre autorização de uso destas substâncias, sendo aprofundada a análise dos procedimentos previstos nos instrumentos legais atualmente em vigor.

Com o objetivo de criar um referencial teórico sobre avaliação de riscos, foi elaborado um capítulo abordando aspectos técnicos da avaliação de riscos, inclusive a questão semântica, mas sem ter a pretensão de esgotar o assunto. Foram apresentadas as principais características da avaliação de riscos, seus conceitos, vantagens, desvantagens, pressupostos, metodologias. É apresentado um resumo sobre os processos de avaliação de agrotóxicos utilizados na União Européia e nos Estados Unidos e como a avaliação de riscos é utilizada para tomada de decisão neste contexto. 
Com relação ao Brasil, foram confrontados os procedimentos atualmente utilizados para tomada de decisão, em nível federal, no processo de registro de agrotóxicos com os procedimentos previstos quando se realiza a avaliação de riscos.

A seguir são apresentadas as duas convenções internacionais (PIC e POPs) relacionadas ao gerenciamento de substâncias químicas ratificadas pelo Brasil no mês de Maio de 2004, destacando as citações relacionadas à exigência de utilização da avaliação de riscos de substâncias químicas presentes nos textos.

Na conclusão são apresentadas diretrizes e recomendações para uma linha de ação em nível federal, que utilize a "avaliação de riscos" de agrotóxicos no processo de registro, e recomendações para o atendimento às exigências relacionadas à avaliação de riscos contidas nas Convenções PIC e POPs. 


\section{OBJETIVOS}

\subsection{Objetivo Geral}

- Fornecer subsídios para a formulação de políticas públicas de gerenciamento de agrotóxicos, baseadas na avaliação de riscos, tendo como foco de análise os atuais procedimentos técnicos utilizados, em nível federal, para o registro dos produtos agrotóxicos e as exigências relacionadas à avaliação de riscos estabelecidas em dois acordos internacionais sobre substâncias químicas (Convenções PIC e POPs).

\subsection{Objetivos Específicos}

- Identificar as linhas gerais da política de gerenciamento de substâncias químicas e, especificamente, dos agrotóxicos no Brasil, a partir da legislação existente;

- Discutir os procedimentos técnicos utilizados para o gerenciamento dos produtos agrotóxicos, relativos à emissão do registro para uso no País, estabelecidos na legislação federal;

- Ofertar subsídios para a formulação de política pública para o registro de produtos agrotóxicos no País, baseados nos requisitos da avaliação de riscos ao meio ambiente e à saúde humana e nas exigências das Convenções PIC e POPs. 


\section{METODOLOGIA}

O interesse particular pelo tema, agrotóxicos e avaliação de riscos, surgiu da experiência profissional pessoal adquirida no governo federal, que permitiu conhecer, participar e acompanhar discussões técnicas relacionadas ao assunto com a finalidade de proposição de políticas públicas federais.

Também contribuiu para a pesquisa a participação em reuniões nacionais e internacionais, no período de 1990 a 2002, quando foram abordadas tanto a factibilidade da implementação de convenções internacionais relacionadas à gestão de substâncias químicas, como os problemas enfrentados pelos países para a implementação da legislação.

A pesquisa realizada tem o objetivo de gerar conhecimentos novos, úteis para o avanço do conhecimento sobre o gerenciamento das substâncias químicas no País.

Do ponto de vista de procedimento metodológico, esta pesquisa é bibliográfica e documental (GIL, 1991), ou seja, foi elaborada a partir de material já publicado constituído, principalmente, de livros, tese, artigos de periódicos, material disponibilizado na Internet, textos de instrumentos legais federais nacionais e internacionais.

A pesquisa é essencialmente descritiva, com a análise dos dados e informações feita de forma indutiva, ou seja, o processo e seu significado são os focos principais de abordagem (SILVA e MENEZES, 2001). A abordagem foi qualitativa e se baseou na interpretação dos fenômenos e atribuição de significados, sem o uso de métodos e técnicas estatísticas.

A revisão de literatura foi realizada com o objetivo de determinação do "estado da arte" (LUNA, 1997), onde se procurou mostrar, em material já publicado, o que se conhece sobre o tema, quais as lacunas existentes e onde se encontram os principais entraves teóricos ou metodológicos.

O levantamento bibliográfico consistiu em pesquisa na literatura disponível sobre avaliação de riscos e na pesquisa em documentos que o governo federal utiliza para gerenciar substâncias químicas, tais como legislação, programas e projetos. Todo material coletado foi analisado e interpretado à luz do tema enfocado neste trabalho - 
o uso da avaliação de riscos de substâncias químicas como ferramenta para tomada de decisão em nível governamental.

Foi considerada a produção científica ligada à área de segurança química publicada em periódicos científicos nacionais e internacionais. Em nível internacional foram consideradas publicações de organizações intergovernamentais, principalmente aquelas ligadas à Organização das Nações Unidas (ONU), quais sejam, Organização Mundial de Saúde (OMS), o Programa das Nações Unidas para o Meio Ambiente (PNUMA) e o Instituto das Nações Unidas Para Treinamento e Pesquisa (UNITAR). Também foram consultados documentos das organizações de saúde e meio ambiente da Comunidade Econômica Européia (CEE), e documentos de órgãos de controle ambiental e de saúde humana de alguns países, principalmente a Agência de Proteção Ambiental dos Estados Unidos - USEPA.

Em nível nacional foram resgatados documentos de domínio público, elaborados pelas instituições federais envolvidas com a questão. Foi verificada a aplicação dos critérios de riscos no processo de avaliação de agrotóxicos, nos órgãos de saúde e meio ambiente, em especial na Agência Nacional de Vigilância Sanitária - ANVISA e no Instituto Brasileiro do Meio Ambiente e dos Recursos Naturais Renováveis IBAMA, respectivamente.

O material de trabalho foi selecionado a partir de perguntas do tipo: Como o risco está sendo abordado em nível internacional? Quais os procedimentos atuais para a autorização do uso de agrotóxicos por parte dos tomadores de decisão? Qual a abordagem de risco que está sendo feita pelo Brasil na avaliação de agrotóxicos? São necessários ajustes para que o Brasil utilize a avaliação de risco como ferramenta de tomada de decisão? Como a estrutura técnica federal, responsável pela implementação das políticas públicas de gerenciamento de substâncias químicas, deve atuar frente às exigências dos acordos internacionais PIC e POPs relacionadas à avaliação de riscos? Quais as recomendações para formulação de uma política pública para o gerenciamento das substâncias químicas (agrotóxicos) no País, tendo como referencial a avaliação de riscos?

O universo das substâncias químicas compreende um amplo espectro que inclui os produtos químicos industriais incluindo, principalmente, os petroquímicos, as fibras 
e fios sintéticos, os produtos farmacêuticos, os agrotóxicos, os sabões, os detergentes e produtos de limpeza, as tintas e vernizes, os explosivos, os adesivos, os catalisadores, os aditivos alimentares, os domissanitários, as substâncias radioativas. Analisar este universo demanda um grau de generalização que, com certeza, gera conclusões irreais.

Desta forma, para tornar a pesquisa mais objetiva e real, foi necessário restringir o escopo do trabalho apenas à classe dos agrotóxicos. Apesar da redução do escopo, a título de contribuição para futuros trabalhos, foi feito um levantamento sobre os instrumentos legais federais voltados para o gerenciamento de outras classes de substâncias químicas, e uma breve avaliação histórica deste processo.

Este trabalho aprofunda-se essencialmente nos aspectos relacionados aos agrotóxicos, incluindo a legislação, os procedimentos utilizados para avaliação para fins de registro em nível federal, e os mecanismos de gerenciamento.

Além do interesse particular por esta classe de substâncias químicas, esta opção justifica-se pelo fato dos agrotóxicos serem a classe de substâncias com arcabouço nacional legal e institucional melhor definido e, também, por existir vasta literatura alertando para o fato de ser esta classe uma das principais quando no que se refere ao impacto adverso ao meio ambiente e à saúde humana, principalmente pelo seu uso disseminado. 


\section{POLÍTICAS PÚBLICAS}

Este capítulo aborda os aspectos gerais da formulação de políticas públicas, com o objetivo de apresentar uma base teórica para a contextualização da pesquisa.

Segundo RIBEIRO (1998), a política é essencialmente a relação entre seres humanos, em grupos sociais ou étnicos, que pode ser feita em escala local ou global, passando por escalas intermediárias. Ainda segundo o autor, como os conflitos em uma sociedade são inevitáveis, a única forma não-violenta de solucioná-los é por meio de entendimentos políticos no âmbito das instituições públicas.

As políticas públicas são escolhas governamentais decorrentes de decisões políticas, e a importância de estudar as políticas públicas se deve ao fato de ser fundamental saber o que o governo faz, porque faz e que diferença faz tudo isto para cada um e para todos os cidadãos, sendo isto denominado de preocupação política (COSTA JÚNIOR, 1998). DYE et al. (1972) definem que política pública é tudo aquilo que os governos escolhem fazer ou não fazer.

GUSTAVSSON (1980), KIVINIEMI (1985) e DAHL (1956) conceituam o campo das políticas públicas como a "relação que se estabelece entre governo e cidadãos, na qual aquele induz estes a agir até mesmo do modo que não desejam" (VIANA, 1996, $\mathrm{s} / \mathrm{n})$.

Os caminhos da ação do Estado se traduzem no ato de fazer políticas públicas e estas são respostas do sistema político às forças advindas do meio ambiente - sociedade (VIANA, 1996). Desta forma, política pode ser definida como as decisões que o governo torna pública e que traduzem suas intenções a respeito de determinado tema.

Existem dois tipos de políticas: as centralizadas, que se caracterizam por estruturas formais, relações de autoridade e controles administrativos, e as descentralizadas, que se caracterizam por controles dispersos, com influência direta dos formuladores de política. Na primeira, a autoridade é centralizada e há artifícios formais de comando e controle e, na segunda, a autoridade é dispersa e há artifícios informais de delegação e entendimento (ELMORE, 1979/80, apud VIANA, 1996).

O conceito de política pública traz no seu cerne a necessidade de metas (ou diretrizes) e objetivos (ou propósitos), além das responsabilidades das instituições 
governamentais e não somente as intenções declaradas dos governos ou de seus agentes.

No sistema constitucional brasileiro, as políticas geralmente expressam-se por meio de leis, mas existem políticas que se traduzem em programas de ação, cujo detalhamento ocorre no formato normativo, ou seja, como decretos, portarias ou resoluções (BUCCI, 1997). Os programas e projetos são instrumentos de decodificação das políticas, e devem apresentar o detalhamento das metas, cronogramas e orçamento.

A formação das políticas públicas pode ser vista como um diálogo entre intenções e ações, um processo contínuo de reflexão para dentro e para fora do sistema político.

Os insumos para uma política pública podem ser internos ou externos. Os insumos externos são demandas originadas no meio ambiente externo ao sistema político, e os insumos internos são demandas geradas no interior do próprio sistema político, ou seja, são demandas dos agentes públicos dos poderes executivo, legislativo e judiciário.

Segundo NAVARRO (2001), a formação de políticas públicas é uma atividade de grande importância da administração pública, sendo fundamental entender quem as elaboram, quem as implementam, quem as avaliam, e quais os fatores que contribuem para que determinada situação seja contemplada por uma política.

Os elementos que interferem na produção das políticas públicas e que são resultantes de uma disputa entre diferentes forças, são os chamados "atores políticos". Eles influenciam e recebem influências, gerando conflito em torno de temas / assuntos, e sempre têm alguma coisa em jogo, podendo vir a perder ou a ganhar. Os atores são, portanto, de alguma maneira afetados pelas decisões e ações que compõem uma política e sempre possuem algum tipo de recurso de poder, que pode afetar as decisões (RUA, 1998).

Os atores envolvidos com uma política são extremamente diversificados quanto aos seus atributos e interesses, podendo ser grupos ou instituições que participam de determinada cena política, ou pessoas, tanto do setor governamental quanto nãogovernamental. 
Atores governamentais são o Presidente da República, os ministros, os senadores e deputados, os políticos do alto escalão, os funcionários de carreira, os governadores, entre outros. Atores não-governamentais são os grupos de pressão ou de interesse, grupos da academia (universidades) ou consultores, da mídia, dos partidos políticos, de opinião pública, dos empresários, de órgãos de representantes de classe, de agências internacionais, além dos trabalhadores e suas entidades de classe. Os atores mais relevantes no processo de produção da política pública são o Congresso Nacional e o Poder Executivo (COSTA JÚNIOR, 1998).

Segundo RIBEIRO (1998), os atores políticos podem possuir uma relação entre iguais ou uma relação de dominação, de submissão, de manipulação, de interação, de diálogo, de enriquecimento mútuo, de cooperação, de competição, de confronto e de conflito ou uma relação entre governantes e governados. Também podem ocorrer relações entre Estado e cidadãos e entre autoridade e obediência. Em última análise, o tipo de relação vai definir o perfil da política a ser formulada.

\subsection{Formação de Políticas Públicas}

Para que uma política pública se concretize são necessárias essencialmente, quatro fases: (1) elaboração da agenda; (2) formulação de política (geração de alternativas e escolha de alternativa); (3) implementação de política e; (4) a avaliação de política (VIANA, 1996). Estas etapas são interligadas e a etapa (4) supri continuamente de informações a etapa (1), para retroalimentar o processo. As atividades de uma etapa posterior são geralmente iniciadas antes da conclusão de etapa anterior. Uma síntese das características de cada uma das fases de formação de uma política pública é:

\section{Elaboração da agenda}

Agenda, neste contexto, é o espaço de constituição da lista de problemas ou assuntos que chamam a atenção do governo (insumo interno) e dos cidadãos (insumo externo). Quando um assunto chama a atenção da sociedade há muito tempo, mas não foi merecedor da atenção do governo, ou seja, não é um item da agenda governamental, é denominado um "estado de coisas" (RUA, 1998). À medida que o "estado de coisas" passa a fazer parte da preocupação das autoridades, ele passa a fazer parte da agenda governamental. Para que o "estado de coisas" se transforme em problema 
político, e seja item prioritário na agenda governamental, é preciso que este mobilize a ação política de grandes e pequenos grupos ou de atores individuais.

Além disso, a priorização de um assunto também pode ocorrer quando há uma situação que exige ação rápida (ex. calamidades ou catástrofes) ou, ainda, quando ocorre ganho político (oportunismo) devido ao levantamento de questões, ou problemas, de forma antecipada.

Segundo COSTA JÚNIOR (1998), a priorização de um assunto na agenda política depende essencialmente de mobilizar a ação política (ações de grandes grupos ou de minorias bem organizadas).

Existem três tipos de agenda: (1) agenda sistêmica ou não-governamental, onde estão os problemas que há anos são preocupação do país sem, contudo, merecer atenção do governo; (2) agenda governamental, que inclui os problemas que merecem a atenção do governo, e (3) agenda de decisão, que lista os problemas a serem decididos. (KINGDON, 1984, apud VIANA, 1996).

Os eventos ou crises podem suscitar a emergência de problema ou assuntos, mas não são suficientes para forçar a entrada de um assunto na agenda, sendo necessário um processo anterior de formação de idéias, que KINGDON (1984) apud VIANA (1996), define como "policy primaveral soup". Nesta etapa, inúmeras idéias são formuladas, mas só algumas sobrevivem por satisfazerem aos critérios de factibilidade técnica, aceitação por grupos de especialistas e pelo público e força de mobilização para um consenso.

Outro aspecto importante, segundo COSTA (1998), é a influência internacional na agenda política. Segundo ele, os estudos sobre políticas mostram que os governos nacionais estão cada vez mais afetados pelos procedimentos de políticas supranacionais, sendo deste modo importante a compreensão do papel das organizações internacionais e da influência delas na definição de agendas nacionais. A proliferação de tratados, declarações e convenções internacionais, são um indicativo da forte influência política das prioridades definidas em nível internacional. Sendo assim, um ponto de fundamental importância na discussão sobre políticas públicas. 


\section{Formulação da política pública}

A etapa de formulação da política insere-se no campo da ciência política, sendo o espaço político de trocas e de indeterminações, de conflitos e de poder. Nesta etapa, ocorre o delineamento da política e a formulação da intenção.

RUA (1998), cita que, na etapa de formulação uma questão deixa de ser "estado de coisas" e se transforma em problema político, uma vez que as alternativas para solução do problema são definidas e cada ator escolhe e exibe as suas preferências e os seus recursos de poder, visando a adoção da alternativa mais satisfatória aos interesses em jogo. Segundo a autora, o ambiente da formulação de uma política pública é carregado de incertezas.

A formulação se divide em duas etapas: (1) geração de alternativas e (2) escolha de alternativa (VIANA, 1996). Na formulação da política existe o confronto direto entre os atores interessados no assunto, ocorrendo discussões sobre o custo-benefício e sobre a geração de alternativas.

Na escolha da alternativa, NAVARRO (2001) destaca a necessidade do confronto de interesses da sociedade, uma vez que toda decisão, quando tomada por quem não é precisamente o destinatário, implica favorecimento do interesse de um e sacrifício de outro. Por isso, aconselha-se que a melhor conduta seja a de pautar pela viabilidade e menor custo da alternativa.

Para que uma política cumpra sua finalidade, é necessário que na etapa de formulação, se tenha clareza quanto ao propósito (objetivo), as diretrizes (metas) para o alcance dos propósitos, as responsabilidades institucionais e o mecanismo de avaliação.

As diretrizes das políticas públicas são as linhas de ação que devem ser seguidas, ou seja, os caminhos para a atuação. As diretrizes originam-se na comparação entre a situação desejada e a presente e devem ser selecionadas a partir dos parâmetros de factibilidade, coerência e viabilidade. Factibilidade diz respeito à disponibilidade de recursos tecnológicos e técnico-científicos administrativos e gerenciais; a coerência diz respeito ao propósito da política; e a viabilidade está relacionada ao grau de possibilidade de sua implementação, inclusive em relação aos interesses dos envolvidos. 
Como as responsabilidades de implementação devem estar claras para formular uma política, é fundamental ter conhecimento dos princípios jurídicos da administração pública, das formas de organização jurídica da administração direta e indireta e dos dados gerados pela administração em seu cotidiano (NAVARRO, 2001). As fases de formulação e implementação são as mais importantes na formação das políticas. A formulação ocorre em um espaço político de trocas e indeterminações, de conflito e de poder, enquanto que a implementação é definida em um espaço administrativo, onde se discutem procedimentos e rotinas (NAVARRO, 2001).

De forma geral, na formulação das políticas públicas, no Brasil, as grandes linhas das políticas públicas, seus objetivos e diretrizes, emanam dos representantes do povo. Desta forma, a formulação é uma tarefa do poder legislativo, ficando o poder executivo imbuído de sua execução (BUCCI, 1997).

A etapa de formulação é a que está mais diretamente sujeita ao grau de influência dos atores e se encerra com a declaração de intenções, mas isto não garante o atendimento da demanda que deu origem ao processo (VIANA, 1996).

Por isso, uma política pública deve ser formulada contemplando os interesses da coletividade, aberto à participação de todos os interessados, diretos e indiretos, com a manifestação clara e transparente das posições em jogo, o que também contribui para sua implementação (NAVARRO, 2001).

\section{Implementação de políticas públicas}

A etapa da implementação da política é quando se dá a operacionalização, ou seja, a declaração de intenções se concretiza. Nesta ocasião, as ações devem ser colocadas de forma objetiva, deixando de ser ciência política e passando a ser ciência social aplicada, com a elaboração de planos, programas, cenários, projetos, procedimentos, cronogramas e rotinas (VIANA, 1996).

Nesta etapa podem ser criadas ou orientadas novas políticas. Esta etapa de implementação é crucial para a explicação do insucesso dos governos em atingir os objetivos estabelecidos (NAVARRO, 2001).

Para SILVA e MELO (2000), como o contexto institucional e organizacional brasileiro caracteriza-se por uma complexa diferenciação funcional, além de 
problemas de coordenação e cooperação intergovernamentais, a má execução da etapa de implementação das políticas públicas tem sido considerada a razão dos insucessos do governo em atingir objetivos estabelecidos na formulação das políticas. Segundo os autores, este argumento é correto no momento em que a etapa de implementação é considerada apenas uma conseqüência da formulação das políticas, ou seja, quando não são considerados os aspectos relativos aos efeitos retroalimentadores [feed back] da implementação sobre a formulação da política.

$\mathrm{Na}$ verdade a etapa de implementação deve ser vista como uma etapa onde se criam políticas e constantemente, se orientam novas políticas, pois a execução implica na tomada de decisão que leva à formulação de novas políticas.

METER e VAN HORN (1975), apud VIANA (1996), afirmam que a extensão da execução das atividades decorrentes de uma política depende da clareza com que as metas e objetivos foram fixados, da consistência com que são comunicados, além disso, da relação entre as atividades que envolvem auxílios técnicos e de informação, e o tipo de controle escolhido, se coercitivo, remunerativo ou normativo.

Para KIVINIEMI (1985), na fase de implementação implantam-se as intenções para obter os impactos e as conseqüências. Nesta etapa revela-se uma estrutura complexa de interação entre público e governo, sendo necessário analisar a participação dos atores não-governamentais, identificando suas idéias, seus valores, os recursos que mobilizam e a sua ação (VIANA, 1996).

Com relação a implementação, BENSON (1978) assinala que o grupo de atores que interagem para a implementação, denominado por ele de rede interorganizacional, deve estar em equilíbrio, ou seja, deve haver um elevado grau de coordenação e interação cooperativa, baseada no consenso e no respeito mútuo, para que a implementação ocorra de forma adequada (VIANA, 1996).

\section{Avaliação de políticas públicas}

A avaliação é a etapa final do desenvolvimento de uma política pública. Uma política pode sofrer uma avaliação do processo, quando a fase de implementação é estudada; ou uma avaliação de impacto, quando são medidos os efeitos derivados de uma política pública. 
A avaliação de processo ocorre durante a fase de implementação, sendo baseada na mensuração da eficiência e eficácia da capacidade organizacional de cumprimento das metas da política. A avaliação de impacto ocorre após a fase de implementação e busca a mensuração da efetividade no alcance dos resultados (VIANA, 1996). Segundo COSTA JÚNIOR (1998) estes dois processos se inter-relacionam, mas tem sido obtido mais progresso em termos de medir eficiência e eficácia do que efetividade (avaliação de impacto).

Para NAVARRO (2001), a etapa de avaliação deve ser utilizada tanto para saber se uma política está sendo implementada, como para avaliar a distância entre as conseqüências pretendidas e as efetivadas, detectando as disparidades entre metas e resultados.

A avaliação da implementação deve levar em conta a estrutura administrativa e organizacional responsável pela execução e as formas de gestão e práticas institucionais que alteram e deslocam objetivos e mobilizam poderes e saberes de agências e técnicos.

Para a avaliação de uma política é fundamental valer-se de dados confiáveis. É uma condição indispensável para que o processo de implementação seja avaliado quanto ao seu sucesso ou fracasso. Para isto, a estrutura técnica e administrativa dos órgãos e agências responsáveis pela geração desta informação são fundamentais.

\subsection{Regulação}

O termo regulação origina-se na palavra regulare, do latin, e significa dirigir, regrar, encaminhar conforme a lei. Regulação é o ato ou efeito de regular. Geralmente a regulação é exercida pelo poder público sobre uma atividade privada (SANCHEZ, 2001).

A regulação é uma prerrogativa do Estado e é caracterizada por uma série de expedientes que visam assegurar que o desempenho de agentes privados, em atividades julgadas relevantes para a sociedade, atende a critérios globais de sustentabilidade econômica e social (CAMPOS et al., 2000).

CORRALES (1998), apud SANCHEZ (2001), coloca a regulação como uma das formas de intervenção do Estado para a orientação das ações e decisões dos agentes 
privados em benefício de interesses sociais e coletivos. Por isso, o estudo do processo regulatório é ao mesmo tempo uma questão econômica, política e legal.

Essencialmente existem dois modelos de regulação: por agência e por processo. O modelo por agência implica na criação de uma organização de regulação centralizada, que controla o cumprimento da norma legal vigente, aplica sanções, fixa ou aprova estruturas tarifárias a serem aplicadas e outorga licenças ou permissões de exploração de serviços. O modelo regulatório por processo caracteriza-se por um sistema descentralizado de instrumentos, práticas e instâncias de exercício da função reguladora (SANCHEZ, 2001).

Assim, o primeiro passo para elaborar uma política pública é conhecer em profundidade o objeto da política, o que contribui de forma fundamental para a efetividade do programa governamental. Quando o assunto passa a ser conhecido, ele passa a chamar a atenção da parcela da sociedade diretamente afetada, gerando a mobilização e passando a fazer parte da preocupação das autoridades e transformando-se em um item da agenda governamental.

Em outras palavras, quando o problema torna-se conhecido ele deixa de ser "estado de coisas" e se transforma em problema político. Em seguida, mobiliza a ação política e passa a constituir-se em uma situação de oportunidade para atores politicamente relevantes.

Um dos pressupostos da formulação de políticas públicas é que as informações sobre a realidade a transformar, a capacitação técnica e a vinculação profissional dos servidores públicos determinarão os resultados da política como instrumento de desenvolvimento, ou seja, grande parte do sucesso de uma política pública está relacionada com a qualidade do processo administrativo que precede a sua realização.

Uma etapa fundamental para a formulação de uma política é a definição dos papéis na administração pública, ou seja, quem elabora, quem implementa e quem avalia os resultados. Além disso, a rede interorganizacional dos atores que estão interagindo para a formulação e implementação da política deve estar em equilíbrio, significando que há entre os participantes um elevado grau de coordenação e interação cooperativa, fundadas no consenso normativo e no respeito mútuo. 
Sabe-se que, como o contexto institucional e organizacional brasileiro caracteriza-se por uma complexa diferenciação funcional, existem muitos problemas de coordenação e cooperação intergovernamentais. A integração das diversas políticas públicas no Brasil tem esbarrado principalmente nos conflitos entre as esferas federais, estaduais e municipais e os diversos atores envolvidos (NARDOCCI, 1999). O ideal seria que todas as instituições públicas fossem orientadas por políticas cujas diretrizes e responsabilidades fossem apresentadas de forma clara. Mas, a realidade institucional caracteriza-se pela descontinuidade, o que compromete o processo de formulação, de execução e de avaliação das políticas.

Neste contexto, no que se refere às substâncias químicas, o controle realizado em nível federal, no Brasil, é bastante disperso, o que gera conflitos de competências e redundâncias regulatórias, além conflitos de entendimento. 


\section{INDÚSTRIA QUÍMICA BRASILEIRA}

Descrever a indústria química brasileira é um desafio, primeiro pela própria característica do setor, que inclui grande variedade de segmentos classificados e citados de forma não harmoniosa; segundo, pela dificuldade de resgatar informações sobre o histórico do setor no país. Ainda assim, um retrospecto e uma contextualização deste setor, no panorama mundial e nacional, é suficiente para demonstrar a sua relevância.

A instalação de um engenho de açúcar, em 1520, é citada como a primeira experiência industrial brasileira. O sabão, o óxido e hidróxido de cálcio foram fabricados desde o início da colonização do país. Os corantes vegetais (pau-brasil, anil, urucum) foram exportados já a partir das primeiras décadas de 1500. Mas é no século XIX, que a industria química começa a ganhar importância e, entre 1808 e 1844, foram fundadas cinco fábricas de pólvora, 30 fábricas de sabão e velas e dez fábricas de produtos químicos diversos (medicamentos, nitrato de potássio, tintas, vernizes, entre outros). Em 1883, foi instalada a primeira fábrica de ácido sulfúrico, em Tremembé (SP). Também em São Paulo, em 1894, foi fundada uma fábrica de ácidos e produtos químicos que expandiu e, em 1918, havia se transformado em quatro estabelecimentos industriais destinados à fabricação de pólvora, sulfeto de carbono, ácido sulfúrico, ácido clorídrico, salitre, amoníaco, adubos, superfosfatos e sulfato de sódio (WONGTSCHOWSKI, 1999; RODRIGUES, 2001).

Por ocasião da Proclamação da República, o Brasil possuía indústrias nas áreas de extração mineral, vegetal e animal, indústria siderúrgica, de papel, de vidro, de cimento, de sabões e velas e, de adubos e inseticidas. Possuía também fábricas de fermentação, de produtos químicos inorgânicos de síntese (hipoclorito de sódio, carbonato de potássio, cloro, ácidos clorídrico e nítrico, iodeto de potássio, iodeto de ferro, cloreto mercuroso, bissulfato de cálcio, hipofosfito de cálcio, nitrato de prata, iodeto de chumbo, carbonato básico de chumbo e sulfato de magnésio) e produtos químicos orgânicos (clorofórmio, éter dietílico, nitrato de etila, ácido tartárico e tartaratos, ácido acético e acetatos, ácido cítrico e citratos, ácido láctico e lactatos, iodofórmio, nitrocelulose e glicerina). Por volta de 1900, muitas empresas multinacionais já haviam se instalado no país (WONGTSCHOWSKI, 1999). 
Como qualquer indústria do setor de transformação, a industria química brasileira tem seu comportamento diretamente influenciado pelo comportamento da economia como um todo. Durante o período da Primeira Guerra Mundial, como quase todas as matérias-primas eram importadas, o governo ofereceu vantagens, por meio de um Decreto Legislativo, de 1917, para o estabelecimento de indústrias para fabricação de algumas substâncias específicas, como o hidróxido de sódio, promovendo, desta forma, o surgimento de novas indústrias químicas (RODRIGUES, 2001).

No período compreendido entre as duas Grandes Guerras Mundiais, na tentativa de substituir produtos químicos importados e diminuir a dependência econômica externa, o país assistiu a um crescimento contínuo da indústria química, com a instalação de grandes empresas multinacionais.

Com o início da Segunda Guerra Mundial, o setor químico viu-se novamente desprovido de importantes fontes de matéria-prima importada e os empresários e técnicos do governo perceberam que era preciso estabelecer bases definitivas da indústria química para suprimento de matéria prima. Deste modo, no período pósguerra, em 1955, destaca-se a instalação de uma unidade de recuperação e purificação de eteno dos gases residuais, em Cubatão, e o estabelecimento, nos anos 60 , de três pólos petroquímicos no país, consolidando a indústria petroquímica brasileira (WONGTSCHOWSKI, 1999).

Nos anos 60, o país se viu desprovido de produtos da indústria de química fina especialmente intermediários de agrotóxicos, fármacos, corantes, pigmentos, catalisadores, aromatizantes, flavorizantes e os aditivos. Em 1974, o Programa Nacional de Fertilizantes e Calcário Agrícolas impulsionou o setor de fertilizantes, promovendo a implantação da Ultrafértil, em Cubatão (SP), e da Valefértil, em Uberaba (MG) (MEIRELLES et al., 1996; RODRIGUES, 2001).

O início dos anos 90 foi de grandes transformações, caracterizadas pelo surgimento de várias empresas nos pólos petroquímicos, pelo desenvolvimento da indústria de fertilizantes, que cresceu 8,3\% ao ano no período de 1960 a 1994, crescimento da indústria de cloro-soda, de 85 mil toneladas em 1962 para 1,11 milhões de toneladas em 1990, e pelo fato de que vários produtos intermediários passarAm a ser produzidos no país (WONGTSCHOWSKI, 1999). 
Após 1990, a indústria de química fina sofreu com a abertura do mercado e a redução de alíquotas de importação, fazendo com que várias unidades fossem desativadas e as empresas multinacionais passassem a aumentar a sua participação, sobretudo no campo dos fármacos e agrotóxicos, que correspondia a aproximadamente $70 \%$ do mercado da química fina no país. Com a queda das barreiras alfandegárias, algumas multinacionais desativaram suas unidades e optaram por importar o produto diretamente de suas fábricas no exterior. Começaram a surgir movimentos de junções, reagrupamentos e aquisições tanto entre empresas nacionais como entre empresas nacionais e multinacionais (WONGTSCHOWSKI, 1999).

Atualmente, em termos de faturamento líquido, a indústria química brasileira está classificada como a nona maior do mundo. Ela participa com 3\% do PIB total do país e 12,5\% do PIB da indústria de transformação, considerando toda a matriz industrial do país. O faturamento líquido da indústria química brasileira em 2002, considerando todos os segmentos, atingiu US\$ 36,6 bilhões, 6\% menor que no ano de 2001 (ABIQUIM, 2002).

O país conta com aproximadamente 218 mil estabelecimentos industriais, que geram quase cinco milhões de empregos. O valor das exportações, em 2002, aumentou 8,44\% e as importações caíram 6,32\%, em relação a 2001. Em termos de volume de produtos químicos, o Brasil importou 16,43 milhões de toneladas em 2001 e 17,1 milhões de toneladas em 2002, enquanto exportou 4,9 milhões de toneladas e 5,7 milhões de toneladas, respectivamente. Do total importado e exportado em 2002, os produtos químicos de uso industrial correspondem a 97,8\% e 97,2\% respectivamente. São denominados "produtos químicos de uso industrial" aqueles que são utilizados no âmbito de outros setores industriais ou da própria industria química, o que no Brasil representa aproximadamente três mil produtos, produzidos por cerca de oitocentas (800) empresas (MMA, 2003).

Estes números transmitem a importância da nossa industria química, tanto no contexto nacional quanto internacional, mas, como todo setor produtivo, ela vive imersa em incertezas de várias naturezas, que a tornam vulnerável.

Com relação a estas incertezas, WONGTSCHOWSKI (1999), cita as de demanda de um produto químico, que são originadas pelos ciclos econômicos, pelos eventos de 
natureza política (por exemplo, a Guerra do Golfo e a crise internacional do petróleo), econômica, social e técnica (substituições e mudanças em produtos). As incertezas de cunho "ecológico-ambientais" são decorrentes da crescente preocupação com a poluição industrial e a conservação do meio ambiente e das conseqüentes alterações que os governos promovem, por meio de restrições ou banimentos de certos produtos químicos. Estas alterações geram variações de demanda e, por conseguinte, aumento da vulnerabilidade das empresas.

As questões regulatórias, concretizadas nos instrumentos normativos publicados pelo governo, também estão incluídas como fatores de geração de vulnerabilidade, pois podem causar impactos na demanda de produtos químicos, principalmente os aditivos da indústria alimentícia, os fármacos, os agrotóxicos e os aditivos de plásticos.

Outra incerteza que contribui para a vulnerabilidade da indústria química é a "incerteza tecnológica", decorrente de restrições impostas ao uso de determinados produtos, e que geralmente se concretiza através de mudanças na legislação. Estas restrições normalmente geram a necessidade de, por exemplo, alterações nos processos de produção, alterações de rotas tecnológicas, mudanças de catalisadores e mudanças na concepção de equipamentos.

Estas e outras incertezas afetam não só o Brasil como as indústrias químicas de todo mundo, mas, a despeito de todas estas incertezas, a indústria química brasileira é um setor de relevância mundial e é fundamental para o desenvolvimento econômico, tecnológico e social do país.

Entretanto, no contexto deste trabalho, interessa-nos particularmente a indústria de agrotóxicos. 


\subsection{A Indústria de Agrotóxicos no Brasil}

O Brasil é classificado como o quarto maior consumidor de agrotóxicos do mundo, e o maior consumidor da América Latina, com consumo estimado em 50\% da quantidade comercializada nesta região (MMA, 2003).

O consumo total de agrotóxicos aumentou de U\$ 988 milhões, gastos em 1981, para U\$ 2,2 bilhões, em 1997 (SILVA et al. 2001). Segundo o SINDAG - Sindicato Nacional da Indústria de Produtos para Defesa Agrícola, as vendas de agrotóxicos, no período de 1999 a 2001, permaneceram na faixa de U\$ 2.3 a 2,4 bilhões, sendo as vendas de herbicidas a mais significativa, oscilando entre 48 e $50 \%$ do total de vendas no período (MMA, 2003).

Em 2000 o consumo nacional de agrotóxicos foi de 158.737 toneladas, com o perfil de consumo no meio rural obedecendo à seguinte ordem: herbicidas $>$ inseticidas $>$ fungicidas $>$ acaricida. Os herbicidas representam mais de $50 \%$ do total de agrotóxicos consumido no país (IBGE, 2004).

A Tabela 1, a seguir, apresenta os principais ingredientes ativos consumidos no país, no ano 2001, sendo o herbicida Glifosato o mais consumido, com mais de 44 mil toneladas.

TABELA 1. Os dez agrotóxicos com maior volume de consumo, em 2000, no Brasil.

\begin{tabular}{lcc}
\hline Ingrediente Ativo & Classe de uso & $\begin{array}{c}\text { Consumo Nacional } \\
(\mathrm{t})\end{array}$ \\
\hline Glifosato & Herbicida & 44.467 \\
2,4 D Ácido & Herbicida & 9.492 \\
Oxicloreto de Cobre & Fungicida & 4.644 \\
Metamidofós & Inseticida & 4.290 \\
Endosulfan & Inseticida & 4.058 \\
Mancozeb & Fungicida & 3.097 \\
Clopirifós & Inseticida & 2.215 \\
\hline
\end{tabular}

Fonte: IBGE, 2004. 
Também no ano 2001, os estados brasileiros com maior volume de consumo de agrotóxicos foram: São Paulo (46.000 t.); Paraná (27.762 t); Rio Grande do Sul (18.265 t); Mato Grosso (16.446 t) e Goiás (13208 t).

Como se observa na Figura 1, apesar do Estado do Paraná ser o que apresenta a maior área plantada, o Estado de São Paulo é o líder no volume de uso de agrotóxicos por hectare.

FIGURA 1 Uso de agrotóxicos ( $\mathrm{kg} / \mathrm{ha}$ ) e área plantada (ha) para vários Estados brasileiros, no ano de 2001.

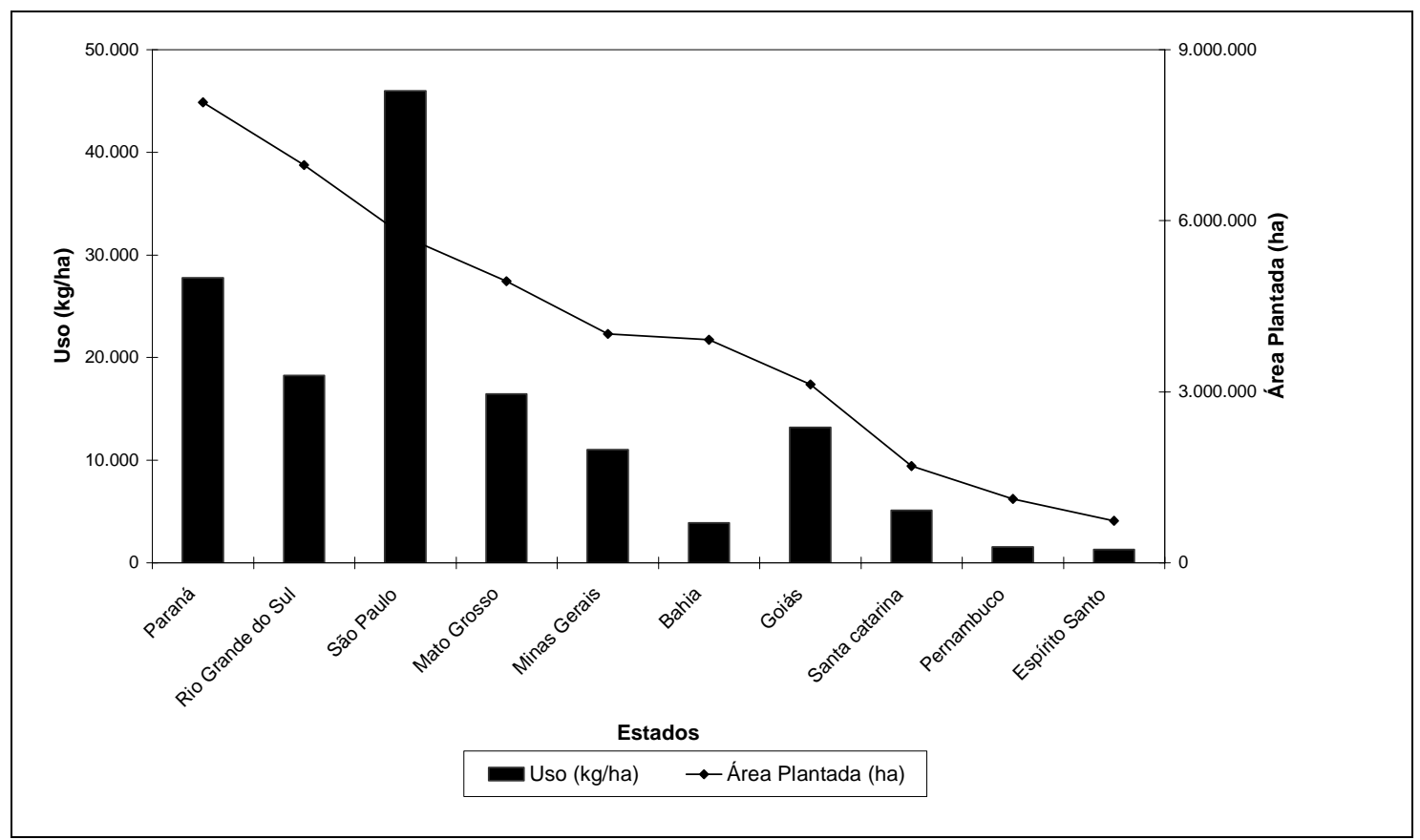

Fonte: IBGE, 2004

É necessário ressaltar que, segundo o IBGE (2004), a agregação territorial da informação de consumo por Estado pode mascarar aquisições feitas em uma determinada região para consumo em outra, o que pode estar ocorrendo com os dados de São Paulo, que congrega o maior número de industrias produtoras de agrotóxicos. Por isso, apesar desta informação permitir que se conheça a distribuição espacial genérica do consumo de agrotóxicos por área, ela apresenta algumas limitações.

Segundo o Sistema de Informações sobre Agrotóxicos - SIA, em maio de 2004, estavam registrados no país, 439 ingredientes ativos (i.a.), 529 produtos técnicos 
(PT) e 1002 produtos formulados (PF). A maioria dos ingredientes ativos registrados é inseticida (134), seguido pelos herbicidas (132). Quanto aos produtos técnicos e produtos formulados, a maioria é de herbicidas (206 e 313, respectivamente), seguido pelos inseticidas (162 PT e $299 \mathrm{PF}$ ). Os fungicidas e os acaricidas ocupam o $3^{\circ}$ e o $4^{\circ}$ lugar, respectivamente (ANVISA, 2002b).

Em um levantamento feito por ALVES FILHO (2002), em agosto de 2000, havia no Brasil, 444 ingredientes ativos registrados, dando origem a mais de 850 produtos formulados, nas diversas classes. Segundo o autor, considerando as diversas formas de apresentação de um produto formulado, na prática, deveria ter em torno de 1.981 produtos formulados no mercado.

Comparando os dados de 2000 com as informações de 2004, observa-se que, em quatro anos, o número de produtos formulados no mercado brasileiro aumentou em aproximadamente $20 \%$.

Com relação à toxicidade dos produtos presentes no mercado, ou seja, a dos produtos formulados - PF, a classe toxicológica predominante, em 2002, foi a Classe III, dos produtos denominados medianamente tóxicos (faixa azul), seguidos pela Classe II altamente tóxico (faixa amarela), Classe IV - pouco tóxicos (faixa verde) e, Classe I produtos extremamente tóxicos (faixa vermelha) (MMA, 2003).

A Figura 2, abaixo, mostra o número de agrotóxicos comercializados, segundo a classe toxicológica. A tendência observada nos últimos quatro anos é de aumento do número de produtos das Classes III e IV, e um comportamento mais estável no número de produtos Classe I e II.

Apesar desta tendência, GARCIA (2001) estudando a evolução do registro de agrotóxicos com relação à periculosidade à saúde e ao meio ambiente, empregando como indicadores os dados de classificação toxicológica e ambiental, concluiu que não foram encontradas diferenças significativas entre a distribuição segundo a classe toxicológica dos ingredientes ativos registrados sob a antiga legislação, Decreto 24.114/1934, e a dos que estão registrados sob a nova legislação (Lei 7.802/1989).

Segundo o autor, antes da Lei 7.802/89 (BRASIL,1989) os critérios de classificação toxicológica empregados no Brasil estabeleciam faixas de maior amplitude para definir as classes de maior periculosidade à saúde, deixando-as com maior 
abrangência que as definidas pela OMS. Mas, em 1992, o Ministério da Saúde - MS publicou critérios para a classificação toxicológica, modificando as faixas para equipará-las às da OMS, por meio da Portaria no $3 / 92$ (ANVISA, 1992) e provocando a reclassificação toxicológica da maioria dos produtos comerciais para classes de menor periculosidade. GARCIA (2001) destaca inclusive, que algumas formulações sólidas, classificadas como Classe I podem ter sido deslocadas não apenas para Classe II, mas também para a Classe III.

FIGURA 2 Número de agrotóxicos comercializados no Brasil, por classe toxicológica, no período de 1992-2002.

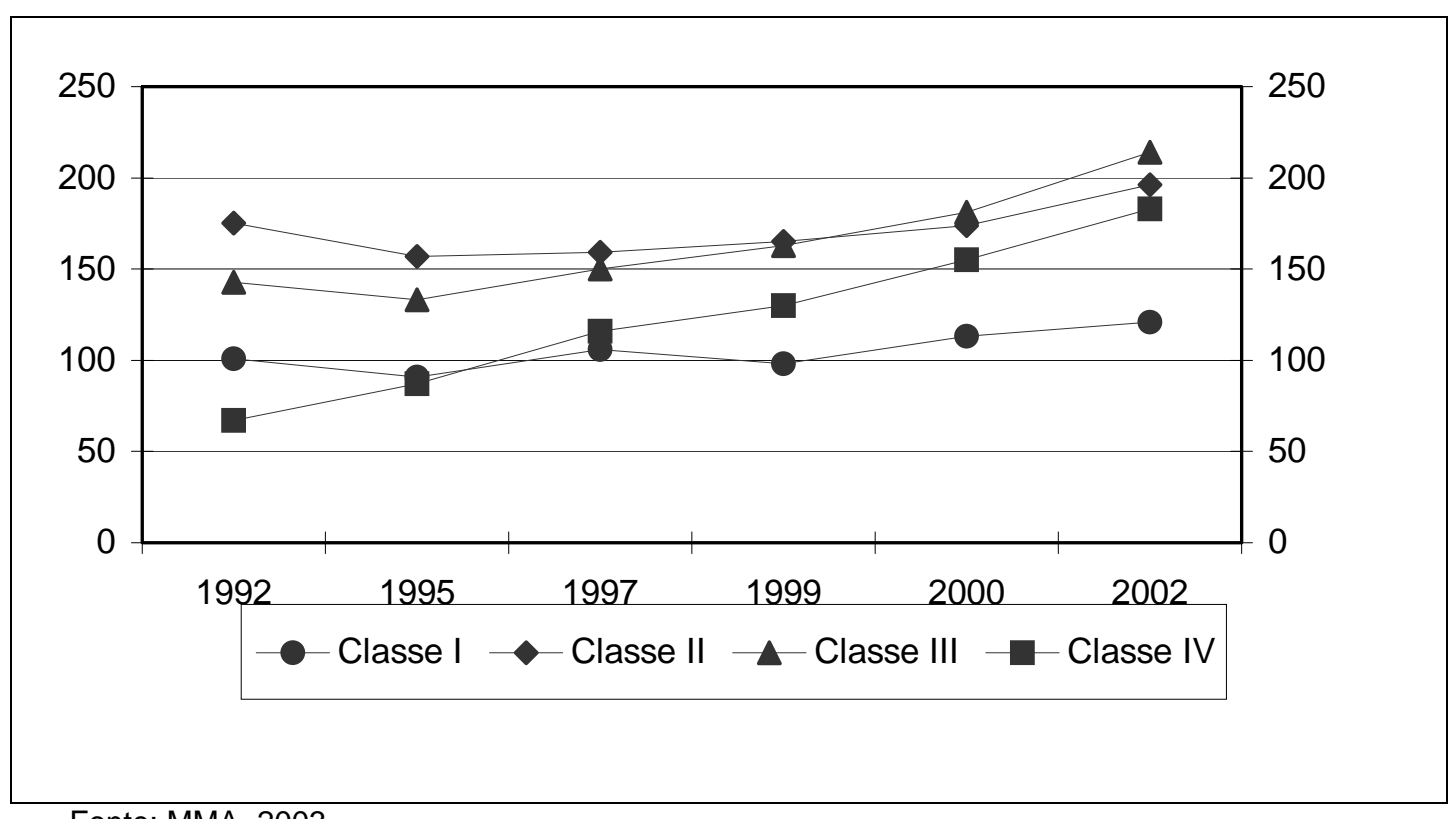

Fonte: MMA, 2003

A utilização dos agrotóxicos no Brasil tem trazido sérias conseqüências, tanto para o meio ambiente como para a saúde do trabalhador rural. Essas conseqüências são, na maioria das vezes, condicionadas por fatores como uso inadequado, alta toxicidade dos produtos, falta de utilização de equipamentos de proteção individual (EPI) e precariedade dos mecanismos de vigilância. Esta situação é agravada pelo baixo nível socioeconômico e cultural da grande maioria dos trabalhadores rurais, que passa a ser a população de mais alta vulnerabilidade (SILVA et al., 2001; SOBREIRA e ADISSI, 2003). 
Segundo SOBREIRA e ADISSI (2003), em 1993, foram registrados seis mil casos de intoxicação por agrotóxicos. Mas, estima-se que este número seja bem maior em virtude da subnotificação, decorrente da dificuldade de diagnóstico das intoxicações relacionadas à agrotóxicos, principalmente os casos subcrônicos e crônicos. Considerando que, para cada caso registrado ocorrem outros 50 sem notificação, ou com notificação errônea, conclui-se que, em 1993, devem ter ocorrido em torno de 306 mil casos.

Outro fator que contribui para a sub-notificação é a dificuldade de caracterizar a relação causa-efeito, nos casos de intoxicação por agrotóxico, sendo geralmente relacionada a outros fatores.

Segundo o SINITOX - Sistema Nacional de Informações Tóxico-Farmacológicas, do Ministério da Saúde e da ANVISA, disponibilizado pela Fundação Osvaldo Cruz FIOCRUZ desde 1996 e uma das únicas fontes de informação sobre notificação de casos de intoxicações por agentes químicos, os três principais agentes que causam intoxicações em pessoas no Brasil são os medicamentos, os animais peçonhentos e os produtos domissanitários. Com relação aos óbitos registrados no SINITOX, os três principais agentes são os agrotóxicos de uso agrícola, os raticidas e os medicamentos (SINITOX, 2003).

Na Tabela 2 a seguir, é apresentado o percentual de letalidade por agrotóxicos, no período de 1997 a 2001, o qual ficou em torno de 3\%. Com relação aos casos de intoxicação por agrotóxicos atribuídos à circunstância ocupacional, o percentual foi, em media, $28 \%$ do total de casos nos anos apresentados.

A despeito dos dados do SINITOX apresentarem uma certa estabilidade com relação ao percentual de intoxicação e letalidade, GARCIA (2001) encontrou uma relação direta entre as curvas de crescimento dos registros de intoxicações e das vendas de agrotóxicos. Neste mesmo sentido, ALVES FILHO (2002) ressalta que, apesar de não existirem dados precisos sobre a quantidade de agrotóxicos utilizado no País, nos últimos anos, observa-se uma relação direta entre os índices de intoxicação e os valores das vendas dos produtos. 
TABELA 2. Dados do número total de casos de intoxicações com agrotóxicos de uso agrícola, no Brasil, no período de 1997-2001, segundo dados do SINITOX.

\begin{tabular}{ccccc}
\hline \multicolumn{4}{c}{ Casos de Intoxicação Humana } \\
\hline Ano & Total & \% & Intoxicação em circunstâncias Ocupacionais \\
\cline { 3 - 5 } & de Casos & Letalidade & $\mathrm{N}^{\mathbf{0}}$ de casos & \% do total de casos \\
\hline 2001 & 5.384 & 2,92 & 1370 & 25,44 \\
2000 & 5.127 & 2,75 & 1378 & 26,87 \\
1999 & 4.674 & 3,29 & 1499 & 32,07 \\
1998 & 5.268 & 3,43 & 1663 & 31,57 \\
1997 & 5.474 & 2,81 & 1457 & 26,62 \\
\hline
\end{tabular}

Fonte: SINITOX, 2003

O aumento do consumo, associado ao despreparo para a utilização da tecnologia, potencializa a probabilidade de ocorrência de danos, que podem ter cunho ocupacional, ambiental e de saúde pública (ALVES FILHO, 2002). O crescimento das vendas de agrotóxicos, acompanhado pelo crescimento das intoxicações, denuncia falhas nos mecanismos de gerenciamento.

Conhecer as políticas existentes no País direta ou indiretamente voltadas para substâncias químicas e, particularmente, para os agrotóxicos, permite a identificação de falhas, ou a ausência de instrumentos legais, as quais contribuem para o agravamento do quadro de contaminação humana ou ambiental no Brasil. 


\section{ASPECTOS INSTITUCIONAIS E LEGISLATIVOS}

Muito tem sido discutido sobre as atividades industriais que provocam a aceleração do efeito estufa, a destruição da camada de ozônio e interferem no clima global, bem como sobre os hábitos da sociedade atual, que utiliza grande variedade de substâncias químicas de forma cotidiana, e dos possíveis danos aos ecossistemas naturais e à saúde humana.

A Agenda 21 (CNUMAD, 1992), ressalta que os riscos ligados às substâncias químicas ignoram as fronteiras nacionais e um maior conhecimento deles é um prérequisito para a segurança química. De acordo com o Capítulo 19 da Agenda 21, nos últimos anos, a contaminação em grande escala por substâncias químicas vem causando graves danos à saúde humana e ao meio ambiente.

Apesar de haver uma preocupação com o uso intensivo e extensivo de produtos químicos e seus efeitos para o homem e seu ambiente natural, a ação de cunho jurídico, visando a melhoria da qualidade de vida e a proteção do meio ambiente, é tema recente. Segundo LEITE e AYALA (2002), este tipo de preocupação só começou a gerar um maior interesse do Estado a partir da constatação da deterioração da qualidade ambiental e das limitações no uso dos recursos naturais, relacionando a crise ambiental com o desenvolvimento econômico, ou seja, a partir de 1970.

Como o conhecimento sobre os efeitos das substâncias químicas para os seres humanos ainda é bastante limitado, as iniciativas internacionais, significativamente as surgidas após a Conferência de Estocolmo, em 1972, são o referencial comum que muitos governos utilizam para elaborar instrumentos regulatórios, com o objetivo de proteger os trabalhadores, a população e o meio ambiente (UNEP/IPCS 1999).

Infelizmente, segundo a UNITAR (1999), a maioria da legislação aprovada nos países em desenvolvimento é fragmentada entre diferentes instituições do governo local, sem uniformidade na abordagem do tema e com pulverização dos recursos destinados à implementação. 
Nos países desenvolvidos a situação não é muito diferente e o desconhecimento sobre as características das substâncias químicas que estão no mercado também é uma realidade.

Segundo BROWN (2003), a maioria dos produtos químicos utilizados na União Européia ainda não possui estudos de avaliação de riscos ou perigo. A Comissão Européia, o braço executivo da Comunidade Européia, cita este problema como uma das justificativas para a proposta de uma nova estratégia política para substâncias químicas denominada REACH (CCE, 2004).

A Agência de Proteção Ambiental dos Estados Unidos - USEPA (sigla em inglês) informou que, em 1998, em torno de 3.000 substâncias químicas tinham o status de $\mathrm{HPV}^{2}$ (High Production Volume), mas que os estudos básicos de toxicidade, incluindo estudos agudos, crônicos, subcrônicos, toxicidade reprodutiva e mutagênese estavam disponíveis para apenas 7\% deles (BROWN, 2003).

Obter informações sobre a situação atual do Brasil com relação às políticas relacionadas às substâncias químicas é uma tarefa bastante complexa. Isto porque ou não se tem informações, ou as informações estão apresentadas de forma truncada ou dispersa, ou não são atualizadas. Alem do documento denominado Perfil Nacional das Substâncias Químicas, elaborado pelo Ministério do Meio Ambiente no ano de 2003 (MMA, 2003), não existem outros estudos oficiais sobre o tema. Existem alguns estudos do setor privado, publicados por associações dos setores produtivos, mas geralmente voltados para a discussão do desempenho das empresas frente as suas próprias metas.

Para discutir o processo de gerenciamento de agrotóxicos no país é necessário, entretanto, conhecer um pouco da sua estrutura institucional para as substâncias químicas de forma geral e, também, os instrumentos legais que têm sido publicados ao longo do tempo.

Desta forma, os itens a seguir abordam o panorama institucional brasileiro relacionado ao gerenciamento de substâncias químicas, e os instrumentos legais

2 Definido pela USEPA como produtos importados e/ou produzidos em volume superior a 1 milhão de Pound ( $\approx 453 t / a n o)$ (Brown, 2003). Na União Européia, HPVCs - High Production Volume Chemicals, são produtos com importação e/ou produção superior a 1000t/ano (BODAR et al., 2002). 
existentes, em nível federal, tanto para substâncias químicas de forma geral como, especificamente, para os agrotóxicos.

\subsection{Panorama Institucional Federal Relacionado às Substâncias Químicas}

O Brasil, como uma federação, possui um regime de descentralização territorial e político-administrativo, sendo as competências da União, Estados e Municípios definidas na Constituição. Estes três níveis possuem como competência comum o cuidado à saúde e assistência pública, a proteção do meio ambiente, e o combate à poluição em qualquer de suas formas.

Os órgãos federais possuem, cada um na sua área, autonomia para elaborar instrumentos de controle, que poderão ser regulamentados de modo mais específico pelos estados, e até municípios, que podem ser mais restritivos, mas não podem contrariar a norma federal.

Conforme a Tabela 4, no anexo I, diversos Ministérios legislam sobre diferentes etapas do ciclo de vida de uma substância química, por exemplo, nas etapas de controle da produção, rotulagem, embalagem, transporte, comercialização, propaganda, uso, importação, exportação, destino final, fiscalização, entre outros.

Vários ministérios, como o do Ministério do Trabalho e Emprego, da Agricultura, do Meio Ambiente, da Saúde, dos Transportes, e da Indústria e Comércio atuam de forma direta sobre a regulação, ou seja, elaboram instrumentos legais específicos para uma determinada substância, na maioria das vezes abordando aspectos técnicos da questão. Por outro lado, ministérios como o da Justiça, da Defesa, da Fazenda e das Relações Exteriores atuam mais no controle da implementação de instrumentos legais, ou no controle do movimento de um grupo restrito de substâncias químicas no País.

Um fato comum na forma de atuação das instituições federais é a criação de conselhos, comissões ou grupos de trabalho e de estudos, para execução de atividades interministeriais, interinstitucionais e intersetoriais. Este modo de atuação geralmente é criado pela instituição coordenadora da atividade que utiliza um instrumento legal, normalmente portarias, ou, em alguns casos, uma convocação 
formal. Esta última opção permite que as convocações se dêem apenas quando a instituição coordenadora julgar necessário, como geralmente ocorre nos Grupos de Trabalho.

Esta forma de atuação das instituições federais leva à não integração de setores que poderiam estar envolvidos em assuntos comuns. As ações descentralizadas são relevantes, mas, no contexto das substâncias químicas, a articulação intersetorial deve ser fomentada visando a concretização de uma base de informações ampla, que auxilie na tomada de decisão, o que, a priori, não é observado no país.

Dentre as instituições listadas na Tabela 4, destacamos algumas que possuem envolvimento mais direto como o foco deste trabalho, e que possuem ações interministeriais ${ }^{3}$, interinstitucionais ou intersetoriais, são elas: Ministério do Meio Ambiente, Ministério da Saúde, Ministério da Agricultura e Abastecimento, Ministério do Trabalho e Emprego e o Ministério do Desenvolvimento, Indústria e Comércio Exterior. Nestas instituições foram identificadas nove instâncias de caráter intersetorial.

O Ministério do Meio Ambiente (MMA) preside o CONAMA - Conselho Nacional de Meio Ambiente, e a CONASQ - Comissão Nacional de Segurança Química, além de coordenar o GT POPs - Grupo de Trabalho para a Convenção sobre os Poluentes Orgânicos Persistentes, e o GT PIC - Grupo de Trabalho para a Convenção Procedimento Prévio de Informação de Conformidade - PIC.

O CONAMA deve ser diferenciado das demais instâncias identificadas pela sua característica de órgão colegiado de caráter normativo, deliberativo e consultivo do MMA, e que integra a estrutura do Sistema Nacional do Meio Ambiente SISNAMA $^{4}$. Dentre as suas atividades, o Conselho assessora, estuda e propõe diretrizes de políticas governamentais para o meio ambiente e os recursos naturais, e delibera, no âmbito de sua competência, sobre normas e padrões (MMA, 2003).

3 Para fins deste trabalho "interministerial" é a relação exclusivamente entre ministérios; "interistitucional" é a relação entre instituições públicas; e "intersetorial" é a relação entre instituições públicas, privadas e outros setores da sociedade civil.

4 O Sistema Nacional do Meio Ambiente - SISNAMA, foi instituído pela Lei Federal nº 6.938, de 31 de agosto de 1981. 
O CONAMA é um Conselho de cunho intersetorial, com participação de representantes federais, estaduais e municipais, entidades de trabalhadores e da sociedade civil, e entidades empresariais, na regulação de diferentes temas afetos ao meio ambiente, incluindo substâncias e resíduos perigosos.

A CONASQ é uma comissão intersetorial de caráter consultivo, mas não deliberativo ou normativo, onde são discutidas questões relacionadas exclusivamente à segurança química. Esta Comissão foi criada pela Portaria MMA n 319/2000 e, atualmente, reúne 22 instituições do Governo Federal, a ABEMA - Associação Brasileira das Entidades Estaduais de Meio Ambiente e representantes da indústria e de organizações não-governamentais e de universidades.

Os principais objetivos da CONASQ são a promoção da articulação intersetorial e o fomento às discussões sobre segurança química, visando a implementação do PRONASQ - Programa Nacional de Segurança Química. Este Programa compreende dez linhas de ação, dentre elas a elaboração de mecanismos de controle e fiscalização na gestão de substâncias químicas; a implementação de Convenções Internacionais (Estocolmo, Roterdã); e, a promoção de rede de intercâmbio e difusão de informações para a segurança química no Brasil (MMA, 2003).

Os grupos de trabalho GT-POPs e GT-PIC foram criados pelo MMA para auxiliar na implementação das Convenções de Estocolmo e Roterdã, respectivamente. Estes dois grupos de trabalho são informais e compostos por técnicos dos ministérios convidados especialmente para cada reunião, que não têm periodicidade préestabelecida.

Além disso, o Ministério do Meio Ambiente, por meio do IBAMA, participa do processo interministerial de registro de agrotóxicos, realizando a avaliação dos aspectos ambientais da questão.

A principal atuação do Ministério da Agricultura e Abastecimento - MAPA, relacionada à substâncias químicas, refere-se ao controle dos agrotóxicos. Ele é o órgão responsável pela emissão do registro dos agrotóxicos e, durante o processo de registro, é responsável pela avaliação da eficiência agronômica do produto.

Outra instituição que se destaca no gerenciamento de substâncias químicas é o Ministério da Saúde, que é o responsável pela política relacionada aos produtos 
domissanitários e farmoquímicos, além de participar do processo de registro de agrotóxicos por meio da realização da avaliação toxicológica dos produtos.

O MS formalizou o "Termo de Cooperação Técnica Saúde e Meio Ambiente - TCT”, com o Ministério do Meio Ambiente, em 2001 (MMA, 2003). O TCT visa ampliar e manter a cooperação interministerial no tocante aos assuntos de saúde e do meio ambiente, mas não foram identificadas ações específicas realizadas sob o escopo deste Termo.

Estes três Ministérios (MMA, MAPA e MS) são os principais envolvidos no gerenciamento de agrotóxicos em nível federal, onde o CTA - Comitê Técnico de Assessoramento de Agrotóxicos, estabelecido por meio do Decreto Federal $\mathrm{n}^{\mathrm{o}}$ 4.074/2002 (BRASIL, 2002a), possui papel de destaque. Este comitê, que possui caráter interministerial e coordenação rotativa entre os três Ministérios, trata de assuntos relativos à agrotóxicos, tais como, harmonização de procedimentos técnicos e administrativos, incorporação de tecnologia, proposição de rotinas e autorização para uso emergencial de agrotóxicos. Os participantes oficiais das reuniões do CTA são os representantes dos ministérios diretamente envolvidos, mas, eventualmente, especialistas podem ser especialmente convidados para tratar de assuntos específicos. Com relação à atuação intersetorial relacionada a substâncias químicas, o Ministério do Trabalho e Emprego - MTE, coordena a CNPBz - Comissão Nacional Permanente do Benzeno, e o Grupo de Estudos da OIT 174, sobre Prevenção de Acidentes Industriais Ampliados.

A CNPBz, criada em 1995, é o fórum tripartite (governo - empregadorestrabalhadores) responsável pela discussão, negociação e acompanhamento das ações para a prevenção da exposição do trabalhador ao benzeno, e pelo acompanhamento da implantação e desenvolvimento do Acordo Nacional do Benzeno (ANB) e da Norma Regulamentadora (NR) $n^{\circ} 15$, do MTE, relativa às atividades e operações insalubres.

O Grupo de Estudo Tripartite para Implementação da Convenção 174 da Organização Internacional do Trabalho, OIT 174, conta com a participação de ministérios, trabalhadores e representantes dos empregadores e possui autonomia para estabelecer diálogo com comunidades expostas e outros setores interessados no 
tema. Tem como objetivo formular propostas para uma política nacional sobre a prevenção de grandes acidentes industriais (acidentes ampliados), e promover o treinamento e a discussão para viabilizar a implementação da Convenção.

O Ministério do Desenvolvimento, Indústria e Comércio Exterior - MDIC, coordena o Grupo GHS, que é ligado à CONASQ. O GHS é um grupo de caráter intersetorial, com a função de discutir mecanismos para incorporar o Brasil ao Sistema Globalmente Harmonizado de Rotulagem [Globally Harmonized System for the classification and labelling of Chemicals] GHS (sigla em inglês). Este sistema, discutido pelo Conselho Econômico e Social das Nações Unidas - ECOSOC (sigla em inglês), órgão coordenador do trabalho econômico e social da ONU, tem como objetivo harmonizar a comunicação sobre os riscos dos produtos químicos, utilizando uma abordagem simples e coerente sobre a definição e classificação de riscos e harmonizando as informações contidas nos rótulos e fichas de segurança (safety data sheet).

Assim, estas são as principais instâncias federais responsáveis pela definição das políticas públicas intersetoriais relacionadas às substâncias químicas. Outras instituições, como o Ministério da Ciência e Tecnologia que utiliza mecanismos intersetoriais para a implementação da Convenção de Armas Químicas - CPAQ, (sigla em inglês), também são relevantes no contexto da segurança química, mas o gerenciamento das armas químicas não é objeto deste trabalho.

Com relação às convenções internacionais ratificadas pelo Brasil, elas apresentam uma situação bastante peculiar. Toda convenção possui um órgão indicado pelo governo federal, denominado "ponto focal", que é a instituição de referência e de coordenação das atividades da convenção no País.

São várias as convenções internacionais relacionadas aos produtos perigosos ratificadas pelo Brasil: Convenção de Basiléia, Convenção de Viena/Protocolo de Montreal; Convenção para a Proibição de Armas Químicas; Convenção OIT 174 para a Prevenção de Acidentes Industriais Maiores; Convenção Internacional para a Prevenção da Poluição Marinha; Convenção Quadro sobre Mudanças Climáticas; Convenção de Roterdã sobre o Procedimento de Consentimento Prévio Informado; e a Convenção de Estocolmo sobre Poluentes Orgânicos Persistentes. 
Todas elas possuem "ponto focal" definido e grupos de trabalho para discutir os mecanismos de implementação. Entretanto, não foram identificados mecanismos formais, ou informais, de interação entre estes grupos, ou seja, eles devem atuar de forma independente, realizando discussões restritas ao estreito círculo de participantes.

Observa-se que a atuação multi/interdisciplinar é um desafio para o Estado, geralmente acostumado a atuar de forma unilateral. Entretanto, é preciso considerar que a sociedade tem recebido informações sobre substâncias químicas das mais diferentes formas e das mais diversas fontes, as quais geram demandas complexas e sofisticadas de gerenciamento.

Caso as políticas para o gerenciamento de substâncias químicas não estejam adequadas para dar um retorno coerente e rápido à sociedade, o Estado passa a atuar apenas "apagando incêndio", o que significa produzir regulamentação unilateral para atender demandas pontuais, na maioria das vezes como conseqüência de acontecimentos que causaram a mobilização da opinião pública.

Além da inexistência de mecanismos integrados de discussão, que resulta em uma grande pulverização das ações em nível federal, também há a pulverização dos recursos, comprometendo ainda mais a eficiência das ações.

O gerenciamento das substâncias químicas exige uma visão holística e não fragmentada ou compartimentalizada da situação. As políticas para este setor devem ser de caráter interdisciplinar e dinâmico, porque o rápido processo de transformação tecnológica e científica, que afeta diretamente o setor, demanda crescente intercâmbio de conhecimento para a correta tomada de decisão.

AUGUSTO e BRANCO (2003), discutindo a política de informação em saúde ambiental, ressaltaram que a pouca articulação entre as diferentes esferas de atuação do Estado, tem gerado políticas pouco integradoras, dificultando a utilização da informação como subsídio para tomada de decisão.

Neste contexto, as atuações integradas são o mecanismo adequado, uma vez que permitem a discussão de forma transversal e favorece a inclusão dos atores afetos à questão. 
Além disso, o processo de elaboração de um instrumento legal regulador deve atender coerentemente às intenções do Estado, que são geralmente norteadas por um referencial legal comum, ou por uma política pública claramente definida. $\mathrm{Na}$ área de saúde ambiental, onde a diversidade dos problemas acarreta em uma enorme dificuldade para a regulamentação, é necessária a infra-estrutura institucional adequada para elaboração de regulação, com técnicos treinados para discutir os problemas e tomar as decisões e estrutura institucional e legal para execução das ações.

Para visualizar a política definida pelo Estado para gerenciar as substâncias químicas, foi feito um levantamento dos mecanismos legais que o país tem utilizado, os quais são a decodificação das intenções do Estado a respeito da questão.

\subsection{Legislação Federal sobre Substâncias Químicas}

O ANEXO II apresenta um resumo da legislação federal relacionada às substâncias químicas (Tabela 5) e dos agrotóxicos (Tabela 6), organizada de forma cronológica. Para as substâncias químicas, são listados as leis e os decretos federais e algumas portarias. Com relação aos agrotóxicos, é listada praticamente toda a legislação federal existente, incluindo a maioria das Portarias Normativas dos órgãos envolvidos no gerenciamento.

Um dos primeiros registros de uma regulamentação brasileira, preocupada com os impactos das substâncias químicas, é o Decreto Executivo nº 16.300, de 31/12/1923, também citado como Regulamento de Saúde Pública (BRASIL, 1923). Este Decreto previa a possibilidade de impedir que fábricas e oficinas, denominadas "indústrias nocivas ou incômodas", prejudicassem a saúde dos moradores e de sua vizinhança, com o isolamento e afastamento (MAGALHÃES, 2002), uma vez que na época acreditava-se que altas chaminés ou o isolamento das indústrias eram a solução adequada para os problemas decorrentes da poluição.

Em 1933, foi aprovado o Decreto $\mathrm{n}^{\mathrm{o}}$ 23.629, regulamentando o embarque e desembarque de inflamáveis, explosivos, corrosivos e produtos agressivos em geral, no porto do Rio de Janeiro (BRASIL, 1933). Esta regulamentação foi necessária devido ao aumento do comércio dessas substâncias resultante da expansão industrial promovida pelo governo, após a Primeira Guerra Mundial. 
O Decreto $\mathrm{n}^{\mathrm{o}} 23.777$, de 23/01/34, regulamentou o lançamento de resíduo industrial das usinas açucareiras ("vinhoto", "tiborna" ou "caxixi") nas águas fluviais, a fim de evitar a sua ação nociva sobre a vida dos peixes. Apesar de não ser um regulamento sobre substâncias químicas, reflete uma incipiente preocupação com os resíduos industriais e a contaminação das águas (BRASIL, 1934a).

Em 1934, foi aprovado o Decreto $\mathrm{n}^{\mathrm{o}}$ 24.114, denominado Regulamento de Defesa Sanitária Vegetal (BRASIL, 1934b). Neste Decreto, os agrotóxicos são citados como produtos "fitossanitários" e não é feita referência aos possíveis danos à saúde humana e ao meio ambiente decorrente do seu uso.

Durante os 30 anos seguintes, não foi elaborado regulamento que fosse relevante para o gerenciamento de substâncias químicas. Apenas em 1961, houve a aprovação do Decreto $n^{\circ} 49.974$, de defesa e proteção da saúde, denominado Código Nacional de Saúde, definindo a autoridade sanitária como responsável pelo controle das substâncias "introduzidas na atmosfera interior ou exterior e consideradas incômodas ou nocivas à saúde", e determinava que os produtos destinados à agricultura, que continham substâncias tóxicas, devam ser obrigatoriamente registrados e ter a venda controlada por repartição federal competente (BRASIL, 1961a).

Ainda, em 1961, foi aprovado o Decreto 50.877 regulamentando o lançamento de resíduos tóxicos e óleos nas águas interiores ou litorâneas do país. O decreto definia o que é poluição, determinava os padrões para águas poluídas (coliformes, DBO, DQO e pH) e multas. A implementação deste decreto era de responsabilidade do Ministério da Agricultura, com a colaboração do Ministério da Saúde, das Forças Armadas: Exército, Marinha e Aeronáutica (BRASIL, 1961b). A promulgação do decreto coincidiu com o boom da indústria petroquímica no País, ocorrido com o estabelecimento de três pólos petroquímicos importantes.

Em 1965, foi aprovado o Decreto $\mathrm{n}^{\circ}$ 55.649, regulamentando as normas para a fiscalização da fabricação, recuperação, manutenção, utilização industrial, manuseio, exportação, importação, desembaraço alfandegário, armazenamento, comércio e tráfego de materiais constantes em uma relação de produtos que eram controlados, na época, pelo Ministério da Guerra (BRASIL, 1965a). 
Também em 1965, a Lei 4.797 obrigou as empresas prestadoras de serviços públicos a empregar exclusivamente madeiras tratadas com substâncias preservantes, definidos como "substâncias químicas que asseguram satisfatória conservação das peças e contribuem para a sua durabilidade" (BRASIL, 1965c). A lei sugeriu que fossem utilizadas, preferencialmente, substâncias de produção nacional e o controle quanto ao tipo de produto, orientação quanto ao uso e autorização para uma possível necessidade de importação de substâncias, ficaria a cargo do Departamento de Recursos Naturais Renováveis do Ministério da Agricultura da época. A Lei não trouxe preocupação quanto à questão dos perigos decorrentes do uso destes produtos. A partir da década de 1970, em função do início das discussões ocorridas em nível internacional, as questões ambientais e a preocupação com os impactos à saúde humana passaram a ser citados mais freqüentemente nos documento legais nacionais sobre substâncias químicas.

Em 1975, foi aprovado o Decreto-Lei $\mathrm{n}^{\circ} 1.413$, dispondo sobre o controle da poluição do meio ambiente provocada por atividades industriais e determinando que as indústrias instaladas em território nacional, ou a se instalarem, seriam obrigadas a promover as medidas necessárias para a prevenção, ou correção, dos inconvenientes e prejuízos da poluição e da contaminação ambiental (BRASIL, 1975a). Neste Decreto-Lei foi definida a adoção do zoneamento urbano.

As medidas de prevenção e controle da poluição industrial propostas no Decreto-Lei 1.413, foram apresentadas no Decreto 76.389/75, que definiu o que é poluição industrial, estabeleceu áreas críticas de poluição e o Programa Tecnológico de Prevenção da Poluição Industrial, com o objetivo de prestar serviços para atendimento à indústria (BRASIL, 1975b).

Naquele momento, foi instituído o cadastro de estabelecimentos industriais junto à Secretaria de Tecnologia Industrial (Ministério da Indústria e do Comércio) com a colaboração da Secretaria Especial de Meio Ambiente (SEMA), na época ligado ao Ministério do Interior, e do Instituto Brasileiro de Geografia e Estatística (IBGE). Este cadastro, que funcionou até início dos anos 90, gerou um arquivo de informações sobre as atividades industriais brasileiras, mas que já foi desativado. 
Em 1976, foi aprovada a Lei 6.360, que dispõe sobre a vigilância sanitária a que ficam sujeitos os medicamentos, as drogas, os insumos farmacêuticos e correlatos, os cosméticos, os saneantes e outros produtos (Brasil, 1976). Por esta lei, as empresas somente poderiam extrair, produzir, fabricar, transformar, sintetizar, purificar, fracionar, embalar, reembalar, importar, exportar, armazenar ou expedir os produtos citados, quando autorizadas pelo Ministério da Saúde, e em estabelecimentos licenciados pelo órgão sanitário dos respectivos Estados.

Em 1977, foi promulgada a Convenção Internacional sobre Responsabilidade Civil em Danos Causados por Poluição por Óleo, regulamentada por meio do Decreto 83.540/79 (BRASIL, 1979). O Ministério da Marinha, por meio da Capitania dos Portos, em conjunto com a Secretaria Especial de Meio Ambiente - SEMA e os Órgãos Estaduais de Meio Ambiente - OEMAs, foram responsabilizados pela implementação da Convenção.

A Lei 6.514/77 realizou alterações na CLT - Consolidação das Leis do Trabalho, relativo à Segurança e Medicina do Trabalho, definindo o Ministério do Trabalho como responsável pela classificação das atividades insalubres e perigosas e pela definição de limites de tolerância e de medidas de proteção do trabalhador, dentre outras competências. Esta lei estipulou os valores dos adicionais de insalubridade (BRASIL 1977).

A partir da década de 1980, começam a aparecer normas para substâncias químicas específicas, sendo a maioria caracterizada pela forte abordagem das questões ambientais. Surgem instrumentos legais produzidos pelo setor ambiental, que passa a assumir responsabilidades concretas e não apenas atuar de forma conjunta ou suplementar com outros setores.

Isto ocorreu com a aprovação da Política Nacional de Meio Ambiente, em 1981 (Lei 6.938/81), que criou o SISNAMA e o CONAMA, e com a criação do Ministério do Desenvolvimento Urbano e Meio Ambiente, em 1985 (BRASIL, 1981). A promulgação da Constituição Federal, em 1988, também foi fator primordial para esta ocorrência. Por exemplo, toda a legislação para o controle de mercúrio e dos PCBs (bifenilas policloradas) e a que trata o início do controle sobre o amianto (asbestos), benzeno e metais pesados, datam da década de 1980. 
Apesar de toda a periculosidade dos PCBs, comercializados no Brasil com o nome de Ascarel $^{\circledR}$, somente na década de 1980, começaram a ser tomadas as primeiras medidas visando o controle do seu uso. Em 1981, foi aprovado a Portaria Interministerial, entre o Ministério do Meio Ambiente, o IBAMA e o Ministério das Minas e Energia, proibindo a implantação de novos processos de produção dos PCBs. Em 1986, duas Resoluções do CONAMA regulamentaram as atividades de transporte, estocagem e uso dos $\mathrm{PCBs}$, criando a necessidade de prévio licenciamento destas atividades no órgão ambiental estadual.

A legislação brasileira não obriga a substituição de equipamentos ainda em uso contendo Ascarel, a que é adequado porque a vida útil dos equipamentos que contém esta substância é bastante longa e não compensa transformá-los em resíduos altamente perigosos quando ainda podem ser utilizados com segurança.

Entretanto a situação dos PCBs no Brasil ainda é pouco conhecida devido à falta de informações sobre o estoque em uso e em desuso e a distribuição destes estoques. Já foram relatados graves acidentes com a substância como, por exemplo, o vazamento de 10 mil litros de Ascarel na subestação de Furnas Centrais Elétricas S.A., em 1987, que atingiram o solo e contaminaram funcionários (PENTEADO e VAZ, 2001).

Mais recentemente, em 2001, durante uma inspeção realizada pelo IBAMA e pela Companhia de Tecnologia de Saneamento Ambiental do estado de São Paulo (CETESB) à subestação da Ferrovia Paulista S/A (FEPASA), em Iperó (SP), foi confirmada a existência de danos ambientais decorrentes do vazamento de 52 mil litros de óleo mineral contaminado com Ascarel. A subestação fica na antiga Estação Varnhagen, dentro da Floresta Nacional de Ipanema, uma área de proteção ambiental. A causa provável do evento foi saques e arrombamentos por moradores das proximidades.

Quanto ao benzeno, o Brasil proibiu, em 1982, a fabricação de produtos que contenham benzeno em sua composição, admitindo apenas a presença como agente contaminante $\left(<1 \%\right.$ v/v). Em 1994, após a promulgação da Convenção $n^{\circ} 136$ da Organização Internacional do Trabalho - OIT sobre a "Proteção contra os Riscos de Intoxicação Provocados pelo Benzeno", por meio do Decreto 1.253/94 (BRASIL, 1994), foi criada a CNPBz - Comissão Nacional do Benzeno, que já elaborou várias 
instruções normativas abordando o controle da intoxicação do trabalhador. Em abril de 2004, foi publicada a Portaria Interministerial $n^{\circ} 775$, entre os Ministérios do Trabalho e Saúde, a qual propõe a redução gradual da concentração de benzeno em produtos acabados, dos atuais $1 \% \mathrm{v} / \mathrm{v}$ para $0,1 \% \mathrm{v} / \mathrm{v}$, até dezembro de 2007 (MTE, 2004).

Sobre o uso do amianto, também denominado de "asbestos", a Resolução CONAMA n5/1986 (CONAMA, 1986) criou uma comissão especial composta por vários setores para discutir a regulamentação e, em 1987, foi publicada a Resolução CONAMA no 7 , regulamentado o uso do amianto (CONAMA, 1997). Em 1991, o Brasil promulgou a Convenção $n^{\circ} 162$ da OIT, sobre a utilização do asbesto com segurança e, em 1995, aprovou a Lei Federal nº 9.055 disciplinando a extração, industrialização, utilização, comercialização e transporte do asbesto/amianto e dos produtos que o contenham, bem como as fibras naturais e artificiais, de quaisquer origens, utilizadas para o mesmo fim (BRASIL, 1995b). Em 1996, foi exigida a rotulagem para produtos que contenham amianto, por meio da Resolução CONAMA 19/96 (CONAMA, 1996). Atualmente discute-se a proibição do amianto e vários municípios do Brasil já aprovaram legislação neste sentido.

O uso do mercúrio e do cianeto na garimpagem do ouro foi regulamentado pelo Decreto $n^{\circ}$ 97.634/89 (BRASIL, 1989), e por Portarias e Instruções Normativas de conteúdo eminentemente técnico. Os regulamentos existentes são de 1989, época da expansão da mineração na Amazônia e dispõem sobre o licenciamento de atividade mineral, o uso do mercúrio metálico e do cianeto em áreas de extração de ouro, e define limites de resíduos em águas e alimentos e cria o cadastro de importadores pelo IBAMA.

Desde 1975, o Ministério da Agricultura proibiu uso de "defensivos agrícolas" a base de metil mercúrio, etil mercúrio e outros alquimercúrio e, em 2001, a ANVISA publicou uma resolução proibindo o uso de compostos mercuriais em medicamentos. O cadastro de importadores, que poderia ser uma ferramenta de auxílio no gerenciamento do mercúrio no país, até o momento, não está sistematizado ou disponível. 
A ocorrência de um evento que mobilizou a opinião pública foi um das principais razões para a resposta do setor político a respeito do transporte de produtos perigosos. Um acidente envolvendo um carregamento de pentaclorofenol (pó-dachina), em 1982, no mercado de São Sebastião, no Rio de Janeiro, levou à elaboração da primeira legislação brasileira relacionada ao transporte de produtos perigosos. Neste acidente, o produto foi transportado em embalagens não padronizadas, descarregadas por operários sem qualquer equipamento de proteção e disposto de forma inadequada, causando a morte de pelo menos três operários. O Decreto Lei $\mathrm{n}^{\circ}$ 2.063/1983, redigido após o evento, dispõe sobre multas a serem aplicadas por infrações à regulamentação na execução do serviço de transporte rodoviário de cargas ou produtos perigosos (BRASIL 1983).

Posteriormente, a Resolução CONAMA nº 005 de 1985, regulamentou as atividades de transporte, estocagem e uso de pentaclorofenol e pentaclorofenato de sódio, que foram condicionadas ao prévio licenciamento nos órgãos estaduais de meio ambiente (CONAMA, 1985).

Em 1988, foi aprovada a Constituição Federal definindo que é competência comum da União, dos Estados, do Distrito Federal e dos Municípios, "proteger o meio ambiente e combater a poluição em qualquer de suas formas" (Art. 23, Inciso IV) (BRASIL, 1988).

O Artigo 225, $\S 1^{\circ}$, Item V, da CF, incumbe ao Poder Público e à coletividade, para assegurar o direito de todos a um meio ambiente ecologicamente equilibrado, “controlar a produção, a comercialização e o emprego de técnicas, métodos e substâncias que comportem risco para a vida, a qualidade de vida e o meio ambiente".

O artigo 200, da Constituição Federal, que trata do setor governamental responsável pela saúde, doravante designado como "setor saúde", define como competências do Sistema Único de Saúde, dentre outras, "participar do controle e físcalização da produção, transporte, guarda e utilização de substâncias e produtos psicoativos, tóxicos e radioativos" (BRASIL, 1988).

Na década de 1990, houve um aprimoramento de alguns instrumentos aprovados na década anterior e o aparecimento de novas preocupações, principalmente com 
relação aos dispersantes de petróleo, poluição por óleos, substâncias que agridem a camada de ozônio, resíduos perigosos e substâncias entorpecentes.

A Lei $n^{\circ} 9.017$ de 1995, cuja implementação está à cargo do Ministério da Justiça, instituiu normas de controle e físcalização sobre produtos e insumos químicos utilizados na elaboração de cocaína e substâncias entorpecentes. Mecanismos regulamentadores posteriores estabeleceram medidas de prevenção e repressão ao tráfico e ao uso indevido de substâncias entorpecentes ou que determinem dependência física ou psíquica (BRASIL, 1995a).

Com relação às novas preocupações desta década, a maioria dos instrumentos legais surgiu em decorrência da adesão do Brasil a acordos internacionais, confirmando que o processo de discussão de uma convenção internacional já gera repercussões internas.

Os clorofluorcarbonos (CFCS) foram proibidos como agente propelente em aerossóis na época da discussão do texto da Convenção de Viena, em 1988, apesar do Brasil só ter ratificado a Convenção em 1990. Da mesma forma, o Brasil ratificou a Convenção de Basiléia em 1994, mas editou vários regulamentos em meados da década de 80 que impediram a entrada de resíduos no País, para qualquer finalidade, inclusive reciclagem de componentes e reaproveitamento de materiais (MMA, 2003). Em fevereiro de 1998 foi aprovada a Lei $\mathrm{n}^{\circ}$ 9.605, denominada Lei dos Crimes Ambientais (BRASIL, 1998), regulamentada pelo Decreto $\mathrm{n}^{\mathrm{o}} 3.179$ de 1999 (BRASIL, 1999), dispondo sobre as sanções penais e administrativas decorrentes de condutas lesivas ao meio ambiente. Esta lei é considerada um marco para a proteção ambiental, pois criminaliza os danos ambientais, definindo pesadas sanções penais.

Com relação à substâncias químicas o Art. 65 da Lei, prevê penas e multas para quem:

“produzir, processar, embalar, importar, exportar, comercializar, fornecer, transportar, armazenar, guardar, ter em depósito ou usar produto ou substância tóxica, perigosa ou nociva à saúde humana ou ao meio ambiente, em desacordo com as exigências estabelecidas em leis ou nos seus regulamentos". (BRASIL, 1998). 
O Art. 43, $\S 1^{\circ}$, do Decreto determina que "incorre nas mesmas penas, quem abandona os produtos ou substâncias citadas, ou os utiliza em desacordo com as normas de segurança" (BRASIL, 1999).

Com relação aos produtos apreendidos, considerados produtos perigosos ou nocivos à saúde humana ou ao meio ambiente, o Decreto determina que devem ter a destinação final, ou a destruição, determinada pelo órgão competente, e correrão às expensas do infrator (Art. $2^{\circ}, \S 6^{\circ}$, Item VII).

A partir do ano 2000, praticamente as mesmas substâncias da década de 90, ou seja, óleos, CFCs, dispersantes e resíduos perigosos, continuaram sendo focadas nas regulamentações.

Em 2000, foi promulgada a Lei $\mathrm{n}^{\mathrm{o}} 10.165$, modificando a Lei $\mathrm{n}^{\mathrm{o}}$ 6.938/81 (Política Nacional de Meio Ambiente), instituindo a Taxa de Controle e Fiscalização Ambiental - TCFA (BRASIL, 2000a). A nova Lei lista as atividades passíveis de fiscalização e fixa taxas proporcionais às escalas de Potencial de Poluição (PP) e o Grau de Utilização (GU) de Recursos Naturais. Segundo MAGALHÃES (2002), esta lei é "louvável” porque é a primeira que cria recursos para a defesa ambiental.

A ratificação das Convenções PIC e POPs, em 2004, são as mais recentes ações legais relacionadas às substâncias químicas no Brasil (PIC, 2004; POPS, 2004).

Além da legislação federal aqui destacada, existem mecanismos não oficiais que auxiliam às políticas de gerenciamento das substâncias existentes. As normas técnicas da ABNT - Associação Brasileira de Normas Técnicas, órgão responsável pela normalização técnica, são um exemplo disto. Estas normas são desenvolvidas e utilizadas voluntariamente e tornam-se obrigatórias quando explicitadas em um instrumento do Poder Público como lei, decreto, portaria ou uma normativa, ou quando citadas em contratos (ABNT, 2004).

Existem mais de 200 normas relacionadas às substâncias químicas, abordando temas que variam desde ensaios de toxicidade, metodologia para determinação da presença de substâncias, procedimentos de limpeza de piscina, até padrões para pós de extinção de incêndio. Existem normas abordando substâncias específicas como, por exemplo, classificação de alumínio e ligas, beneficiamento de minério de ferro, álcool etílico hidratado para a indústria alcoolquímica, entre outros. Foram 
identificadas 47 normas relacionadas aos agrotóxicos, geralmente tratando de metodologia para análises em laboratório e manuseio dos produtos durante o transporte (ABNT, 2004).

Apesar dos instrumentos legais brasileiros apresentarem aspectos importantes para avaliação do controle das substâncias, a efetiva implementação não é conhecida, uma vez que não existe um mecanismo que permita identificar a necessidade de aprimoramento destes instrumentos, ou seja, que permite um feed back destas políticas.

Observa-se que as instituições federais mais atuantes no gerenciamento das substâncias químicas são os Ministérios do Trabalho, Saúde, Meio Ambiente e Transportes, juntamente com suas instâncias executivas (agência, instituto ou fundação).

A questão dos agrotóxicos é abordada em seis ministérios - Meio Ambiente, Saúde, Trabalho e Emprego, Agricultura Pecuária e Abastecimento, Desenvolvimento Indústria e Comércio Exterior e Fazenda, sendo que três deles (MMA, MAPA e MS) trabalham mais estreitamente para o registro de produtos.

O panorama apresentado sobre os instrumentos legais existentes para gerenciar as substâncias químicas em nível federal caracteriza-se por ações desconectas e impulsionadas por eventos específicos ou por pressão internacional.

De forma geral, a legislação aborda o gerenciamento à medida que ocorrem eventos que impactam a opinião pública, numa visão claramente remediadora. $\mathrm{Na}$ grande maioria das vezes a legislação faz referência a substâncias específicas e com poucas exceções tratou de um grupo de substância. Entretanto, não se sabe se as substâncias agraciadas com instrumentos legais realmente representam as prioridades do país, uma vez que não existem critérios definidos para considerar determinada substância prioritária.

Alguns produtos considerados prioritários em um determinado momento, como benzeno, agrotóxicos, amianto, mercúrio, substâncias do Protocolo de Montreal e os resíduos perigosos são reincidentemente considerados nos programas de controle de produtos químicos existentes. 
O país gerencia as substâncias químicas de uma forma tradicional, ou seja, individualiza o perigo das substâncias e atua por meio da fiscalização de padrões de emissão ou da proibição ou exigência de licenciamento.

Ou seja, a grande maioria dos instrumentos legais é do tipo "comando e controle", que tem como linha de ação a fixação de normas e padrões e a fiscalização do seu cumprimento. Este tipo de instrumento geralmente estimula apenas as soluções de remediação por parte do setor afetado (BARBIERI, 1997) e depende essencialmente da estrutura institucional do Estado para serem implementados, sendo criticados pelo alto custo que acarretam. Este formato de gerenciamento beneficia o setor privado com outorgas emitidas pelo Estado, na forma de autorizações, licenças ou registros, e socializa os custos do controle dos padrões e da fiscalização, que é realizado exclusivamente pelo Estado.

Apesar de não se ter indicadores da eficácia dos mecanismos de comando e controle, estes instrumentos não tem sido suficientes para garantir um adequado gerenciamento, se considerarmos os problemas de contaminação ambiental, intoxicação humana.

Esta visão tradicional não é compatível com as demandas sociais atuais, caracterizadas pela existência de riscos amplos e complexos, que exigem estratégias e instituições integradas, voltadas para múltiplos meios e múltiplas fontes de risco.

Instrumentos políticos de caráter econômico (tributação, subsídios, licenças, incentivos fiscais) é uma exceção neste levantamento. Os instrumentos de caráter administrativo, como cadastros, rede de informação, emissão de relatórios, quando existem, como no caso do mercúrio, não estão implementados ou as informações não estão sistematizadas ou disponibilizadas para serem consultadas, perdendo assim a sua razão de existir.

\subsection{Legislação Federal sobre Agrotóxicos}

No Brasil os agrotóxicos e afins ${ }^{5}$ destacam-se entre as substâncias químicas devido ao seu amplo uso, propriedades toxicológicas.

5 Definição de acordo com art. $2^{\circ}$, I, da lei 7.802, de 11.7.89, publicada no DOU de 12.7.1989. 
Os agrotóxicos são considerados relevantes no modelo de desenvolvimento da agricultura no país. Em 1975, por meio do Programa Nacional de Defensivos Agrícolas (PNDA), foram destinados US\$ 200 milhões para a implantação e desenvolvimento das indústrias de agrotóxicos (PESSANHA e MENEZES, 1975).

Em decorrência da larga utilização destes produtos no País, eles possuem uma ampla cobertura legal, com um grande número de normas legais, e com muitas atividades de voltadas para a implementação da legislação.

A farta publicação de leis faz com que o Brasil possua um arcabouço legal voltado para o gerenciamento dos agrotóxicos compatível ao dos países mais desenvolvidos. Entretanto, a rigidez da legislação, por si só, não garante que apenas produtos seguros estejam sendo comercializados (GARCIA, 2001), ou esteja sendo promovida a redução dos riscos destes produtos.

O controle sobre os agrotóxicos remonta à década de 20, quando foi aprovado o Regulamento de Defesa Sanitária Vegetal - Decreto $\mathrm{n}^{\mathrm{o}}$ 15.198/1921 (TOMITA, 2004). Em 1934, foi aprovado o novo Regulamento de Defesa Sanitária Vegetal, por meio do Decreto $\mathrm{n}^{\mathrm{o}}$ 24.114/1934, que serviu de referência para o registro de agrotóxicos no País, até a aprovação da Lei 7.802/89 (BRASIL, 1989).

Ambos os decretos tiveram como preocupação definir os procedimentos necessários e obrigatórios para evitar a disseminação de pragas e doenças decorrentes do trânsito de produtos vegetais no país, incluindo a sua exportação, mas não abordam os aspectos relacionados aos danos ao meio ambiente e à saúde humana decorrente deste uso, o que só viria a ocorrer na década de 1970.

Devemos destacar, entretanto, que estes decretos foram aprovados em uma época em que os produtos organossintéticos não eram empregados como agrotóxicos, o que veio a ocorrer a partir da Segunda Guerra Mundial, com a descoberta das propriedades inseticidas do DDT - Dicloro-difenil-tricloroetano (TOMITA, 2004).

Os primeiros registros de compostos organoclorados no Brasil ocorreram em 1946 e o surgimento da indústria de formulações ocorreu em 1948, alavancada pela demanda decorrente do surgimento de muitas pragas nas principais culturas do País (ALVES FILHO, 2002). Entre 1946 e 1948, a presença de pragas, como o gafanhoto migratório, a broca-do-café e as pragas do algodoeiro incrementaram o consumo de 
produtos agrotóxicos formulados, devido às campanhas fitossanitárias com a utilização, principalmente, de BHC, DDT e Parathion. Este fato estimulou o surgimento de indústrias de formulação, que processavam produtos técnicos importados e nacionais, como o Parathion e o BHC. Segundo ALVES FILHO (2002), durante os anos 1954 a 1960, foram registrados no Ministério da Agricultura em torno de 2.045 produtos.

Só na década de 60 , surgiu a primeira norma legal incorporando o setor saúde no controle dos "produtos destinados a fins de agricultura". O Decreto no 49.974/1961 determinou que o registro e o licenciamento de "inseticidas" dependeriam de prévia manifestação do órgão federal de saúde com relação aos "riscos" que poderiam vir a acarretar à saúde humana (BRASIL, 1961a). Tal atividade foi proposta sem citação quanto aos meios para sua implementação, o que nos leva a concluir que o termo risco foi utilizado simplesmente como sinômino de perigo.

O artigo 65, deste Decreto, ressalta que os produtos tóxicos destinados à agricultura devem ser obrigatoriamente registrados e ter a venda controlada por repartição federal competente, ter rótulos com a composição química e com a observação destacada de constituir produto "venenoso", além do antídoto de emergência.

Em 1965, o Ministério da Agricultura aprovou a Lei $n^{\circ} 4.785$, referente à fiscalização de "produtos fitossanitários", sendo o Departamento de Defesa e Inspeção Agropecuária responsável pela especificação e caracterização dos produtos químicos, das preparações e das matérias-primas da composição dos "defensivos" (BRASIL, 1965b). Esta Lei definiu que os produtos fitossanitários são:

Art. $2^{\circ}$. "....as substâncias ou preparações de natureza química ou biológica, e os organismos vivos quando destinados ao emprego na prevenção, repelência e destruição de insetos, fungos ervas daninhas, nematódios, ácaros, roedores e outras formas de vida animal ou vegetal e outros agentes que afetam as plantas e os produtos agrícolas" (BRASIL, 1965b).

Neste caso, além dos termos "defensivos" e "produtos fitossanitários" serem utilizados de forma indistinta, se referindo a mesma coisa, são apresentados apenas os aspectos positivos dos produtos, fato que é repetido até o início da década de 70 . 
Em 1965, a Lei no 4.797 determinou que as repartições públicas deveriam utilizar exclusivamente madeiras previamente tratadas com produtos preservantes, mas não alerta para os perigos advindos desta prática e define o Ministério da Agricultura como órgão responsável pelo controle da atividade (BRASIL, 1965c).

$\mathrm{Na}$ década de 1960, começaram a surgir os produtos denominados de terceira geração - semioquímicos (ferormônios), fisiológicos (diflubenzuron) e biológicos (Bacillus thuringiensis) que, por serem menos tóxicos, indicavam que a indústria química mundial começava a incluir, como parte de sua estratégia, a preocupação com o homem e o meio ambiente (ALVES FILHO, 2002).

A publicação do livro "Primavera Silenciosa", de Rachel Carson, em 1962, causou grande comoção e fomentou estudos sobre os efeitos dos agrotóxicos sobre a saúde humana e a discussão sobre os impactos decorrentes do uso de agrotóxicos, servindo de estímulo para vários países elaborarem normas legais com a finalidade de restringir o uso dos produtos.

Segundo GARCIA (2001), neste momento a legislação federal brasileira não acompanhou a evolução do setor e foi observado o aumento do consumo e do número de intoxicações de agricultores. Segundo ALVES FILHO (2002), no final da década de 60 , a produção brasileira de agrotóxicos limitava-se a alguns organoclorados (DDT e BHC) e a política dos órgãos governamentais era bastante liberal em relação à importação de ingredientes ativos e formulações.

Entretanto, a partir da década de 1970, a constatação de intoxicações em trabalhadores rurais, resíduos em alimentos, contaminações do solo e da água, além de novos conhecimentos de toxicologia, deram inicio à construção de um novo entendimento sobre as implicações do uso destes produtos e começou a ser reconhecido o risco decorrente do uso abusivo dos produtos.

Esta década é rica em portarias normativas para substâncias destacadas como problemáticas no cenário mundial, como o DDT, em evidência no livro de Rachel Carson, e outros organoclorados. Além disso, a Guerra do Vietnã, ocorrida entre os anos de 1954 e 1975, evidenciou o poder e os problemas do uso dos herbicidas desfolhantes como arma de guerra, como o famoso "agente laranja" ( 2, 4-D + 2, 4, $5-\mathrm{T})$. 
O Decreto 67.112/70 determinou um controle, essencialmente burocrático, sobre as empresas produtoras, ao definir que só poderiam operar com licença do Ministério da Saúde, para o caso de produtos domissanitários (uso doméstico) ou do Ministério da Agricultura, para o caso de produtos "fitossaneantes ou zoossaneantes" (TOMITA, 2004).

Em 1971, foram publicadas, na mesma data, duas portarias do Ministério da Agricultura, proibindo a fabricação e comercialização de DDT e BHC para combate a ectoparasitas em animais domésticos - Portaria n ${ }^{\circ}$ 356/71 (D’AMATO et al. 2002); e outra proibindo o uso de organoclorados em pastagens - Portaria 357/71 (D’AMATO et al. 2002; TOMITA, 2004).

Além dessas, na década de 1970, o Ministério da Agricultura publicou a Portaria $\mathrm{n}^{\circ}$ 393/72, proibindo o uso de organoclorados na cultura do fumo; a Portaria $n^{\circ} 326 / 74$ proibindo o uso do produto 2,4,5 T (ácido 2,4,5 - triclorofenoxiacético) em florestas e margens de rios, lagos, açudes, poços e manaciais e a Portaria $\mathrm{n}^{\circ} 002 / 75$, proibindo o uso de "defensivos agrícolas" a base de metil, etil e alquil mercúrio (TOMITA, 2004).

No final dos anos 70, ocorreram várias ações relacionadas à rotulagem, a embalagem, aplicações e comércio, visando proteger a saúde humana e o meio ambiente. Em 1979, o MAPA publicou a Portaria $n^{\circ} 220$, tratando da rotulagem de produtos (GARCIA, 2001).

De forma geral, semelhante ao que ocorreu com as outras substâncias químicas, a década de 70 caracteriza-se pelo aparecimento de instrumentos legais preocupados com os impactos dos agrotóxicos à saúde humana e ao meio ambiente, ainda que de forma extremamente tímida, e utilizando como principais mecanismos de gerenciamento, a proibição e o licenciamento.

Também nesta década, no âmbito da agricultura, o termo "defensivo agrícola" passou a ser utilizado em substituição ao termo "saneante" o que, segundo TOMITA (2004), pode ser um indício desta preocupação. Entretanto, a Lei 6.360/76 ainda manteve o termo saneante, denotando a falta de entendimento entre os setores.

Entre 1974 e 1980, a indústria de agrotóxicos apresentou um acelerado crescimento. Neste período foram estabelecidos os II PND - Plano Nacional de Desenvolvimento, 
e o PNDA - Plano Nacional de Defensivos Agrícolas, além da implementação de políticas de isenções para importação de ingredientes ativos, preservando as formulações fabricadas no País (ALVES FILHO, 2002).

Em 1976, a Lei Federal 6.360, definiu que as empresas só poderiam, por exemplo, extrair, produzir, fabricar "saneantes" e outros produtos citados, quando autorizadas pelo Ministério da Saúde e em estabelecimentos licenciados pelo órgão sanitário dos respectivos Estados. (BRASIL, 1976).

Na década de 80, o gerenciamento de agrotóxicos em nível mundial já estava em franca implementação. No Brasil, esta década se caracteriza pelo aparecimento de instrumentos legais impondo maior restrição sobre os agrotóxicos, culminando com a aprovação da Lei 7.802, em 1989, instrumento legal atualmente em vigor para o gerenciamento destes produtos (BRASIL, 1989).

ALVES FILHO (2002), destaca que, nesta década, por motivos econômicos, o País apresentou retração das vendas de agrotóxicos, em reflexo do clima de instabilidade financeira e da redução do volume de crédito disponível. Além disso, o meio empresarial começou a preocupar-se com as primeiras mudanças legislativas de regulamentação dos produtos.

O Ministério da Saúde publicou, em 1980, a portaria DISAD nº 4, estabelecendo normas para a classificação toxicológica e solicitando informações relacionadas aos efeitos sobre o meio ambiente - toxicidade para peixes, organismos aquáticos inferiores, aves, abelhas e fauna silvestre; acumulação na cadeia alimentar, deslocamento no ambiente, persistência, degradação no ambiente e toxicidade do produto degradado GARCIA (2001).

Esta é a primeira norma legal que solicita de testes específicos para subsidiar a tomada de decisão em nível de governo federal. Até então, os mecanismos de controle se baseavam na proibição, ou no licenciamento de estabelecimentos produtores.

No mesmo ano, o Ministério do Trabalho elaborou várias Normas Regulamentadoras Rurais - NRR, incluindo a NRR $\mathrm{n}^{\mathrm{o}} 5$ sobre produtos químicos (agrotóxicos, fertilizantes e corretivos) (MTE, 2004). 
Em 1981, o Ministério da Agricultura empreendeu várias ações para controle dos “defensivos agrícolas". Foram publicadas duas Portarias, de $\mathrm{n}^{0} 25$ e 22, definindo que os produtos destinados ao tratamento de sementes deveriam ter corante para que a semente tratada fosse diferenciada da não tratada (MAPA, 1981b,a). Além disso, a Portaria $\mathrm{n}^{\mathrm{o}}$ 007/81 implantou o receituário agronômico e instituiu o cadastro obrigatório de varejistas, revendedores, distribuidores e cooperativas junto às Delegacias Federais de Agricultura - DFA, visando estabelecer uma maior fiscalização sobre o comércio dos produtos de venda controlada (TOMITA, 2004).

Em 1985, o Ministério da Agricultura publicou a Portaria $n^{\circ}$ 6, tratando da renovação de registro de agrotóxicos e passando para a Secretaria Especial do Meio Ambiente (SEMA), do Ministério do Interior, a responsabilidade pela solicitação e análise dos dados sobre efeitos ao meio ambiente (GARCIA, 2001). Esta Portaria, apesar de incluir o órgão ambiental, recém estruturado por meio da Lei 6.938/81 (BRASIL, 1981), não definiu a sua participação no processo de registro.

A Portaria do MAPA n ${ }^{0}$ 329/85, proibiu a comercialização, o uso e a distribuição de agrotóxicos organoclorados destinados à agricultura. Alguns dos produtos listados, como o DDT, ainda puderam ser utilizados como produto domissanitário, em campanhas de saúde pública ou na agricultura, em situações emergenciais. Apenas em 1998, o DDT foi vetado pelo Ministério da Saúde, passando a ter todos os usos proibidos (MAPA, 1985).

Em 1989, a Portaria Interministerial n 292 passou para o IBAMA a responsabilidade pela análise e registro dos produtos preservantes de madeira, até então controlado pelo Ministério da Agricultura (IBAMA, 1989).

A partir do final da década de 1980, a consideração sobre os aspectos de saúde e meio ambiente para o gerenciamento dos agrotóxicos passaram a ocupar espaço mais significativo, principalmente em nível estadual.

GARCIA (2001) ressalta a iniciativa do Estado do Rio Grande do Sul, na década de 1980, de regulamentar o controle de agrotóxicos em âmbito estadual. TOMITA (2004) cita a Lei $n^{\circ} 4.002$ do Estado de São Paulo, de 1984, como a responsável pela definição do termo "agrotóxico" e pelas normas e critérios para classificação toxicológica e ecotoxicológica, utilizadas posteriormente na redação da Lei 7.802/89. 
Segundo a autora, a lei estadual abordou de forma ampla a questão dos agrotóxicos, tentando integrar os setores de saúde, meio ambiente e agricultura, mas sofreu vetos por legislar uma questão que, na época, dizia respeito à União.

Toda esta discussão foi considerada por ocasião da aprovação da Constituição Federal de 1988 que, além de abordar diretamente a questão das substâncias tóxicas em vários artigos, criou medidas para o aperfeiçoamento dos instrumentos de defesa ambiental, dentre elas o Programa Nossa Natureza.

O Programa Nossa Natureza foi criado em 1989, e implementado por meio da atuação de seis Grupos Interministeriais - GTIs. Estes grupos discutiram e propuseram novas leis ambientais, além de reestruturar o setor administrativo ambiental, unificando as atividades administrativas do IBAMA e criando a Secretaria do Meio Ambiente, vinculada à Presidência da República (MAGALHÃES, 2002).

No âmbito de um dos GTIs do Programa Nossa Natureza foi redigida a Lei $n^{\circ}$ 7.802/89 (MAGALHÃES, 2002), Lei dos Agrotóxicos, tendo como referencial uma proposta elaborada por uma comissão composta por representantes dos diversos setores, incluindo indústria e entidades ambientalistas (GARCIA, 2001).

De forma geral, nos anos 90, observa-se uma nova abordagem da indústria dos agrotóxicos, com a aplicação dos conhecimentos de biologia molecular e engenharia genética às tecnologias químicas, que gerou o descobrimento de novas moléculas, desenvolvimento de culturas transgênicas e de inimigos naturais resistentes aos agrotóxicos e a evolução dos produtos em termos do modo de ação, estrutura, especificidade e origem (ALVES FILHO, 2002).

A Lei $n^{0} 7.802$, aprovada em 1989, marca a vitória da etapa de organização do processo de regulamentação dos agrotóxicos (ALVES FILHO, 2002). Ela dispõe sobre a pesquisa, a experimentação, a produção, a embalagem e rotulagem, o transporte, o armazenamento, a comercialização, a propaganda comercial, a utilização, a importação, a exportação, o destino final dos resíduos e embalagens, o registro, a classificação, o controle, a inspeção e a fiscalização de agrotóxicos, seus componentes e afins (BRASIL, 1989).

Para tratar desta questão tão complexa foi proposta uma sistemática interministerial para o controle e registro dos produtos, delegando responsabilidades para os 
Ministérios da Agricultura, Saúde e Meio Ambiente e responsabilizando o primeiro pela emissão final do registro. Esta sistemática permite que as substâncias sejam avaliadas não só quanto a sua eficácia agronômica, como o era antes de 1989, mas também quanto aos impactos à saúde humana e ao meio ambiente.

A partir da Lei 7.802/89, o termo "defensivo agrícola", que destorcia o conceito e fugia da linha da terminologia internacional, que é "pesticida", foi substituído pelo termo "agrotóxicos", que destaca a noção de produto perigoso (MACHADO, 1999), deixando claro para o agricultor e para a população que o produto é tóxico (LAZZARINI, 1989; GARCIA, 2001).

Segundo a definição contida na Lei, "agrotóxicos e afins" são:

“(a) os produtos e os agentes de processos físicos, químicos ou biológicos, destinados ao uso nos setores de produção, no armazenamento e beneficiamento de produtos agrícolas, nas pastagens, na proteção de florestas, nativas ou implantadas, e de outros ecossistemas e também de ambientes urbanos, hídricos e industriais, cuja finalidade seja alterar a composição da flora ou da fauna, a fim de preservá-las da ação danosa de seres vivos considerados nocivos; b) substâncias e produtos, empregados como desfolhantes, dessecantes, estimuladores e inibidores de crescimento (art. $2^{\circ}$, I) (BRASIL, 1989).

Esta lei impõe maior restrição e controle no uso destes produtos, definindo o trâmite interministerial para obtenção do registro e exigindo o Registro Especial Temporário (RET) para os agrotóxicos em fase de pesquisa e experimentação.

Além disso, ela definiu várias situações de restrição ou proibição do registro, como: o registro de um novo agrotóxico somente deverá ocorrer se a sua ação tóxica sobre o ser humano e o meio ambiente for comprovadamente igual ou menor ao de outros já registrados, para o mesmo fim; proibir o registro de agrotóxicos que não disponham de métodos para desativação e que não haja antídoto ou tratamento eficaz no Brasil; proibir o registro de agrotóxicos com características teratogênicas, carcinogênicas ou mutagênicas; proibir o registro de agrotóxicos mais perigosos para o homem do que os testes de laboratório tenham podido demonstrar; e proibir o registro de agrotóxicos cujas características causem danos ao meio ambiente. 
Foram definidas também instâncias que podem solicitar o cancelamento ou impugnação do registro; requisitos para as embalagens dos agrotóxicos, proibindo o fracionamento ou a reembalagem; definição das informações que devem constar dos rótulos (classificação toxicológica, instruções para utilização, informações sobre os perigos potenciais à saúde humana e ao meio ambiente); e as penas e multas pelo descumprimento.

Foi instituída a obrigatoriedade do Receituário Agronômico, para a venda de agrotóxicos, e definidas as responsabilidades administrativa civil e penal para o profissional, os usuários, o comerciante, o registrante, o produtor e o empregador, pelos danos causados. Um ponto de fundamental importância nesta lei é a delegação de competências à União, Estados, Distrito Federal e Municípios, para legislar sobre agrotóxicos.

A Lei foi regulamentada pelo Decreto $n^{\circ}$ 98.816/1990 (BRASIL, 1990a), que foi redigido por uma comissão interministerial coordenada pelo Ministério da Agricultura, e integrada pelos Ministérios da Saúde, do Interior (atual Meio Ambiente) e pela Secretaria de Assessoramento de Defesa Nacional.

Segundo GARCIA (2001), o processo de regulamentação não foi tão amplamente discutido e negociado como a Lei, gerando alguns retrocessos como, por exemplo, o fato da Lei proibir o registro de agrotóxicos para os quais não havia antídoto eficaz e a regulamentação abrir exceção para aqueles produtos "usados em concentrações comprovadamente não letais para os homens e animais" (Art. 22 Item II). Esta ressalva foi retirada apenas em 2002, por ocasião da revogação do Decreto 98.816/90, conforme será citado adiante.

De acordo com o Decreto regulamentador, compete ao Ministério da Saúde avaliar e classificar toxicologicamente os agrotóxicos, seus componentes e afins e estabelecer os parâmetros para rotulagem com relação à saúde humana, além de definir os limites máximos de resíduos em alimentos.

A determinação do potencial de periculosidade ambiental é responsabilidade do Ministério do Meio Ambiente. Cabe ao Ministério da Agricultura, a responsabilidade de avaliar a eficiência agronômica e emitir o registro final, depois de ouvido os órgãos federais de meio ambiente e de saúde. Além disso, o MAPA deve estabelecer 
os parâmetros de rotulagem e as técnicas agronômicas e fiscalizar os estabelecimentos produtores (fabricantes e formuladores).

A Figura 3, abaixo, apresenta de forma sintética as linhas mestras do procedimento de registro proposto pela legislação dos agrotóxicos. As setas tracejadas indicam o procedimento no caso de deferimento do pedido de registro e as setas pontilhadas representam o procedimento no caso de indeferimento.

De acordo com o Decreto 98.816/90, os fabricantes e detentores do registro submetem ao Ministério da Agricultura o Relatório Técnico I, em que constam informações relativas à eficácia agronômica do produto; ao Ministério da Saúde submetem as informações a respeito da toxicidade ao homem (Relatório Técnico II); e ao IBAMA submetem o Relatório Técnico III, com os dados e informações relacionadas ao seu potencial de periculosidade ambiental (BRASIL, 1990a).

As informações solicitadas para os relatórios técnicos, e as orientações para os requerentes dos registros, são definidas por cada órgão, separadamente. O Decreto também definiu prazos para cada órgão concluir sua avaliação.

FIGURA 3 Síntese do processo de registro de agrotóxicos de acordo com a Lei $7.802 / 89$ e o Decreto $98.816 / 90$

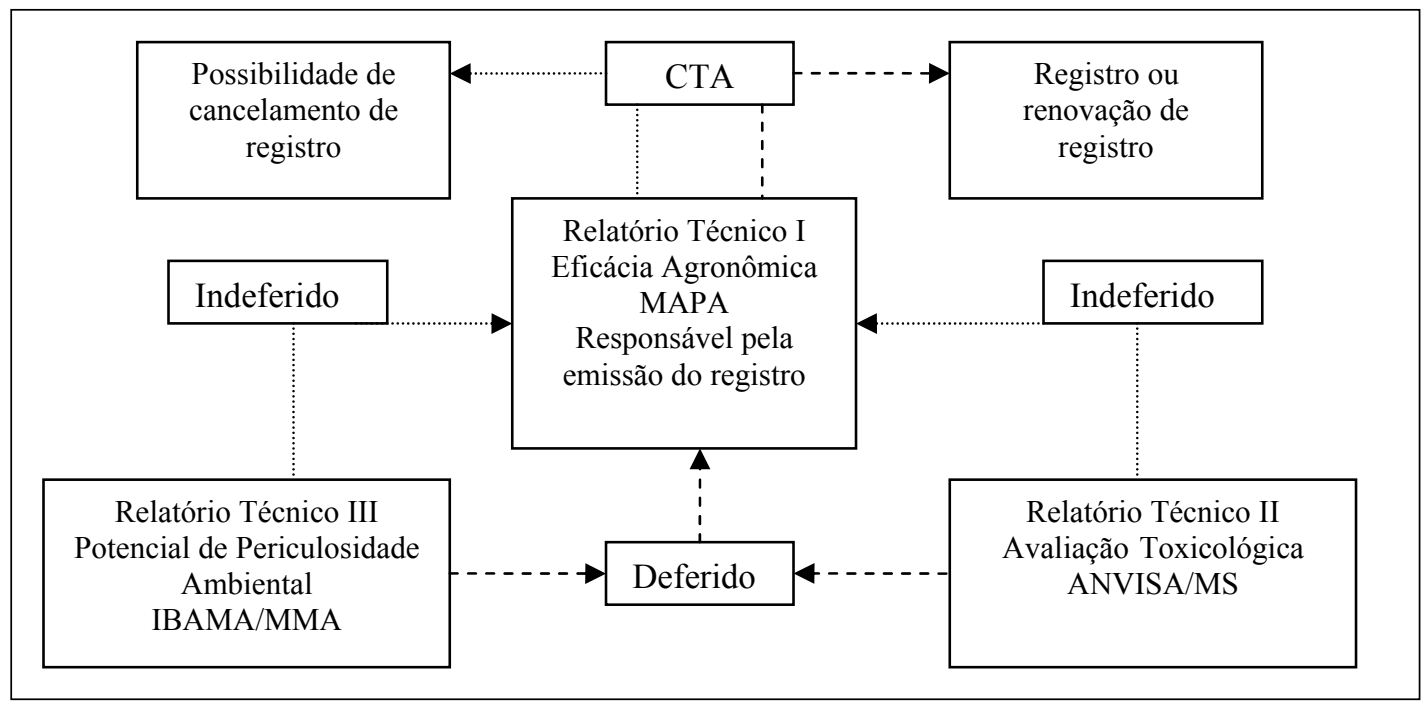

Fonte: Decreto 98.816/90 (BRASIL, 1990) 
Depois de analisar os relatórios, os órgãos federais de saúde e de meio ambiente emitem parecer, deferindo ou indeferindo o pedido de registro ou a renovação de registro, cabendo ao Ministério da Agricultura acatá-los ou discuti-los, no âmbito da Comissão de Assessoramento Técnico - CTA, constituída em 1991, por meio da Portaria Conjunta nº 86, assinada pelos três ministérios (BRASIL, 1991).

O Decreto determina que os agrotóxicos deverão ser divididos em classes, com a finalidade de diferenciá-los em função de sua utilização, seu modo de ação e seu potencial toxicológico ao homem, aos seres vivos e ao meio ambiente.

A classificação, com relação à toxicidade humana, é: extremamente tóxico (classe I), altamente tóxico (classe II), moderadamente tóxico (classe III) e pouco tóxico (classe IV). A classificação quanto ao potencial de periculosidade ambiental não é apresentada no Decreto, sendo esta uma atividade a ser realizada posteriormente pelo cargo do órgão ambiental federal.

Todos os órgãos estabeleceram seus critérios e exigências para fins de avaliação. $\mathrm{Na}$ ocasião o IBAMA definiu, por meio da Portaria $n^{\circ} 349 / 90$, os procedimentos para registro, renovação de registro e extensão de uso de agrotóxicos, e definiu o prazo a partir do qual só seriam aceitos testes realizados nas condições reais do País (IBAMA, 1990). Esta Portaria foi alterada em 1994, com a aprovação da Portaria Normativa $\mathrm{n}^{\circ}$ 139, que foi revogada em 1996, com a publicação da Portaria Normativa $\mathrm{n}^{\circ} 84$ (IBAMA, 1996).

Por ser um tema novo na legislação brasileira, a regulamentação ambiental foi a que mais sofreu modificações para incorporação de mecanismos de aperfeiçoamento do processo de análise ambiental.

O Ministério da Agricultura definiu, na Portaria $n^{\circ} 45 / 1990$, os documentos que o requerente do registro deveria enviar para fins de obtenção de registro, renovação de registro e extensão de uso de agrotóxicos seus componentes e afins (MAPA, 1990). Esta Portaria definiu parâmetros para os testes de eficiência agronômica e foi complementada em 1996.

O Ministério da Saúde ratificou, na Portaria no 3 de 1992, os termos das "Diretrizes e orientações referentes à autorização de registros, renovação de registro e extensão de uso de produtos agrotóxicos e afins" publicados em 1991 (ANVISA, 1992). Esta 
portaria revogou a Portaria DISAD n $n^{\circ}$ /80, a Portaria $n^{\circ} 5 / 80$ e a Portaria $n^{\circ} 25 / 87$, e foi alterada no ano 2000, pela Resolução RDC n 44/2000, da ANVISA, com a atualização do formato do relatório de estudos de resíduos de agrotóxicos (ANVISA, 2000a).

A Portaria 3/92 definiu os procedimentos para avaliação de agrotóxicos e estabeleceu diretrizes e exigências para a avaliação e classificação toxicológica, fixação de limites máximos de resíduos de agrotóxicos (LMRs), e exigências relativas à segurança dos aplicadores e da população em geral. De forma significativa, ela alterou a classificação toxicológica em vigor no país, definida na Portaria DISAD n ${ }^{\circ}$ $5 / 80$, modificando as faixas para equipará-las à da OMS, acarretando problemas por reclassificar toxicologicamente a maioria dos produtos comerciais para classes de menor periculosidade (GARCIA, 2001).

Um ponto importante que deve ser destacado na legislação de agrotóxicos é o fato da Lei 7.802/89 determinar a não concessão de registro para produtos mais tóxicos que outro já registrado para o mesmo fim, e o Decreto 98.816/90 apenas determina os parâmetros para a avaliação comparada - toxicidade da formulação, presença de problemas toxicológicos especiais (neurotoxicidade, fetotoxicidade, ação hormonal e comportamental, e ação reprodutiva), persistência no ambiente, bioacumulação, formulação e, método de aplicação, sem apresentar os critérios para a comparação (BRASIL, 1990a).

Sem a definição dos critérios de comparação é impossível prever como este mecanismo poderia ser utilizado. Desta forma, o que realmente se observa é que este artifício de comparação, que pode significar a negativa de registro, não foi utilizado enquanto o Decreto 98.816/90 esteve em vigor, ou seja, até 2002.

Vários aspectos da Lei dos Agrotóxicos e do Decreto demandaram a publicação de regulamentações específicas, como a Portaria nº 14/1992, do Ministério da Saúde, que estabeleceu as normas para a avaliação toxicológica dos agrotóxicos e afins destinados à pesquisa e experimentação, que deve ser realizada dentro de parâmetros que minimizam os riscos à saúde dos pesquisadores e da população em geral (MS, 1992). 
No ano de 1992, foi obtido o primeiro resultado concreto à luz da nova legislação, quando três produtos organoclorados - Aldrin, Clorobenzilato e Dodecacloro - foram proibidos após análise interministerial.

O Aldrin foi cancelado a pedido da própria empresa, que não tinha mais interesse na manutenção do registro. O Dodecacloro, por meio da Portaria 91/92, teve sua proibição acompanhada de uma proposta de gerenciamento do estoque existente naquele momento e do controle do uso do produto remanescente (MAPA, 1992b). O Clorobenzilato, que já havia sofrido restrições para uso na agricultura em 1985, teve a produção, exportação, importação, comercialização e a utilização na agricultura totalmente proibida e, em 1998, o Ministério da Saúde o excluiu da lista de substâncias autorizadas para uso como domissanitário.

A questão da renovação do registro prevista na Lei 7.802 criou uma situação que merece citação. A Lei definiu que as empresas possuidoras de registro sob a égide do Decreto de 1934 teriam seis meses, a partir do Decreto 98.816/90, para adequar seus registros frente a nova legislação, sob pena de cancelamento. Os novos registros emitidos passariam a ter validade de 5 (cinco) anos, renovável a pedido do interessado.

A lei também determinou que os titulares do registro de produtos agrotóxicos, cujos componentes fossem organoclorados, deveriam submeter-se à imediata reavaliação de seu registro pelo trâmite interministerial, tendo o prazo de 60 (sessenta) dias, a partir do Decreto 98.816/90, para manifestar-se sobre a sua reavaliação, sob pena de terem o registro cancelado automaticamente.

Estas determinações fizeram com que os três ministérios, logo após a provação do Decreto 98.816, fossem abarrotados de processos de renovação de registro. Como conseqüência, o prazo de "adequação" dos registros foi ajustado por meio do Decreto $\mathrm{n}^{\mathrm{o}}$ 99.657/90, que prorrogou o prazo dos registros que venciam em janeiro de 1991 para julho do mesmo ano (BRASIL, 1990b).

Em 1993, a situação continuava sem solução, com os três órgãos pendentes quanto à responsabilidade de avaliar os processos de renovação. A solução encontrada foi a publicação do Decreto $n^{\circ}$ 991/93, suspendendo a validade do registro e definindo que os produtos que apresentassem redução da eficiência agronômica, ou riscos à saúde 
humana e ao meio ambiente, poderiam ser chamados para reavaliação a qualquer tempo, e que poderiam ter seus registros cancelados, suspensos ou alterados (BRASIL, 1993)

Como não havia mais justificativa para a renovação do registro, uma vez que a reavaliação poderia ser feita a qualquer momento, os processos de renovação de registro que estavam em trâmite foram suspensos e arquivados pelo Ministério da Agricultura.

GARCIA (2001) considera que a eliminação da renovação do registro amenizou a situação das empresas, mas foi uma decisão que não favoreceu os interesses do ponto de vista da segurança no trabalho, saúde pública e meio ambiente, sendo considerado um retrocesso.

Realmente, como o processo de gerenciamento de agrotóxicos no Brasil está baseado na emissão do registro pelo Estado, que automaticamente torna-se responsável tanto pela fiscalização posterior, como pelos problemas de saúde que eles possam vir a causar à população, o momento da renovação do registro seria a oportunidade para possíveis restrições ou proibições.

O Decreto $n^{\circ} 991 / 93$, ao mesmo tempo em que aliviou a máquina administrativa dos processos de renovação, passou para o poder público a responsabilidade de, por seus próprios meios, identificar os produtos problemáticos do ponto de vista de impactos adversos à saúde humana e ao meio ambiente.

Entretanto, o que houve foi um erro estratégico da legislação ao propor, logo no inicio da implementação de um sistema complexo, um processo rotineiro de renovação obrigatória de registro, priorizando o grande número de produtos antigos, e exigindo do País uma infraestrutura institucional que não existia naquele momento.

Entretanto, se a estratégia de avaliação fosse orientada para um maior controle sobre os novos produtos que solicitam registro, e a reavaliação produtos antigos fosse realizada de forma gradual, as chances de sucesso teriam sido maiores.

A Comunidade Européia tem um exemplo semelhante, mantendo as devidas proporções, uma vez que o mecanismo de gerenciamento está baseado em um sistema de diferenciação entre produtos novos e antigos (existentes), com priorização 
dos últimos. A inoperância deste sistema é uma das justificativas para a implementação da nova política relacionada à substâncias químicas, que tem seu foco na avaliação mais restritiva dos produtos novos, enquanto os produtos antigos serão avaliados de forma gradual.

A identificação de um produto que está em uso regular no comércio, mas que necessita de reavaliação, demanda o aprimoramento das instituições para que possam identificar estes produtos e gerar dossiês que subsidiem a ação do Estado.

Até hoje, no Brasil, conforme será discutido adiante, o processo de avaliação ainda está muito centrado na restrição e na proibição de produtos antigos.

A partir do arquivamento dos processos de renovação, que estavam sobrecarregando a máquina administrativa, os três órgãos federais passaram a dedicar-se publicação de normas relacionadas às exigências do processo de registro.

Em 1994, o Ministério da Agricultura publicou critérios para avaliação de inclusão e exclusão, de indicações de uso e orientações sobre rótulo e bula, e o IBAMA publicou a Portaria $n^{\circ} 139$, alterando os procedimentos para a avaliação do potencial de periculosidade ambiental (IBAMA, 1994).

De forma geral, as principais inovações da Portaria $n^{\circ}$ 139/94 do IBAMA, foram a definição das características dos produtos que podem vir a receber a classificação de "produto de periculosidade impeditiva à obtenção de registro" e a definição da classificação quanto ao potencial de periculosidade ambiental (Art. $2^{\circ}$ ).

Esta classificação, que tem como parâmetros a bioacumulação, a persistência, o transporte, a toxicidade a diversos organismos, o potencial mutagênico, carcinogênico e teratogênico do produto, obedece à seguinte graduação: Classe I Produto Altamente Perigoso; Classe II - Produto Muito Perigoso; Classe III - Produto Perigoso e; Classe IV - Produto Pouco Perigoso.

A portaria listou os documentos necessários para a avaliação ambiental e os testes que deverão ser realizados em laboratórios credenciados ou reconhecidos pelo INMETRO e cadastrados no IBAMA, recomendando a metodologia apresentada no "Manual de Testes para avaliação de Ecotoxicidade de Agentes Químicos”, editado pelo IBAMA (IBAMA, 1990). 
Em 1995, o Ministério da Agricultura publicou a Portaria $\mathrm{n}^{\circ} 67$ regulamentando a mistura de tanque ${ }^{6}$, ressaltando as vantagens desta prática e instruindo as empresas a colocarem esta indicação nos rótulos e bulas de seus agrotóxicos (MAPA, 1995). Esta determinação do setor agrícola, realizada de forma unilateral, não incluiu a possibilidade dos órgãos de saúde e meio ambiente realizarem uma prévia avaliação destas misturas e negligenciou a capacidade de antagonismo ou sinergismo entre os ingredientes ativos e seus possíveis efeitos adversos.

Apenas em 2002, por meio da Instrução Normativa $\mathrm{n}^{0} 46$, o Ministério da Agricultura determinou às empresas titulares de registros de agrotóxicos a retirada das indicações de misturas em tanque dos rótulos e bulas, reconhecendo a necessidade de avaliação prévia dos aspectos de agricultura, saúde e meio ambiente. (MAPA, 2002)

O ano de 1996 foi marcado pela publicação de instrumentos legais para regular ações paralelas ao registro. O Ministério da Saúde, por meio da Lei ${ }^{\circ}$ 9.294, determinou restrições à propaganda de vários produtos, dentre elas os agrotóxicos (BRASIL, 1996). O Ministério da Agricultura instituiu o cadastro dos estabelecimentos formuladores, fabricantes, importadores e exportadores de agrotóxicos, e definiu os critérios para o credenciamento de entidades privadas de ensino e pesquisa para desenvolvimento e realização de ensaios experimentais com estas substâncias. Com a Portaria $n^{\circ}$ 160/96 o MAPA fez complementações aos procedimentos definidos nas Portarias 45/90 (MAPA, 1990) e 84/94 (MAPA, 1994), solicitando informações sobre o método analítico para a determinação dos resíduos do ingrediente ativo (i.a.) e seus derivados nas culturas indicadas na solicitação de registro, bem como para a determinação do teor de ingrediente ativo (i.a.), na formulação (MAPA, 1996).

O IBAMA alterou pela terceira vez a portaria sobre procedimentos para a avaliação do potencial de periculosidade ambiental, revogando a Portaria $n^{\circ}$ 139/94 e publicando a Portaria $n^{\circ} 84 / 96$, que vigora até o momento, merecendo uma análise detalhada (IBAMA, 1996). A nova Portaria institui o "Sistema Permanente da Avaliação dos Agrotóxicos seus componentes e afins", compreendido por cinco

6 Portaria 67/1995, Art. 1º §único - "Entende-se por mistura em tanque a prática de associar, imediatamente antes da aplicação, agrotóxicos ou afins necessários ao controle de alvos biológicos que ocorrem simultaneamente, para os quais não se obtenha eficácia desejada com um único produto" (BRASIL, 1995). 
subsistemas: (1) classificação do potencial de periculosidade ambiental, (2) estudo de conformidade, (3) avaliação do risco ambiental, (4) divulgação de informações, (5) monitoramento ambiental e fiscalização.

Foi mantida a mesma classificação do "Potencial de Periculosidade Ambiental", prevista na Portaria 139/94 (IBAMA, 1994), além da possibilidade de classificação como "produto de periculosidade impeditiva à obtenção de registro". O estudo de conformidade é um mecanismo que o Instituto pode utilizar para aferir as informações apresentadas.

A Portaria 84/96 consta de dez anexos: os anexos I, II e III tratam do formato do Relatório Técnico III; os anexos IV, $\mathrm{V}$ e $\mathrm{X}$ trazem as informações a serem apresentadas; o anexo VIII trata da apresentação semestral pelas empresas do relatório de produção; o anexo IX trata da cobrança para a manutenção do processo de avaliação; e o Anexo VII apresenta o formato da ficha que deve ser elaborada pela empresa após a obtenção do registro.

O anexo VI apresenta a grande inovação desta portaria, a inclusão do procedimento de avaliação de risco ambiental, que poderá ser solicitada quando o IBAMA julgar necessário, ou quando o cruzamento da classificação do potencial de periculosidade e a finalidade de uso do produto justificar a necessidade da geração de dados de campo.

Segundo a portaria, a avaliação de risco poderá ser realizada para produtos formulados registrados ou em processo de registro, e pode implicar em alteração, suspensão ou cancelamento do registro. Para realizar este estudo a empresa terá que apresentar o "Termo de Compromisso para elaboração do estudo de risco ambiental" conforme o anexo VI, onde também constam as informações necessárias para o estudo.

O "Estudo do Risco Ambiental", também apresentado no anexo VI, exige as informações cadastrais da empresa e do laboratório executor do estudo; dados do produto - nome químico, número CAS, marca comercial e classe do produto, indicação de uso, dose, método, intervalo e número de aplicações; identificação e descrição do agroecossistema utilizado no estudo; informações sobre os corpos d'água existentes (nome, temperatura, profundidade e vazão média, $\mathrm{pH}$ e dureza da 
água); descrição da vegetação da área de influência direta e da ocorrência de fauna silvestre; classificação, $\mathrm{pH}$, temperatura e umidade do solo; e dados sobre o escoamento Superficial (run off) e deriva.

GARCIA (2001), considera que o estabelecimento da avaliação de risco ambiental é o passo mais importante para o aprimoramento das exigências e coloca o Brasil em uma situação equiparada aos dos países desenvolvidos no que se refere ao arcabouço legal. Entretanto, mesmo sendo um mecanismo legal restritivo e inovador, se não for adequadamente implementado não repercute em resultados positivos para a sociedade em geral.

Como já discutido no Capítulo sobre políticas públicas, a citação de um procedimento em uma norma legal retrata a intenção dos políticos (legisladores) com relação àquela questão, mas não garante a sua implementação. Neste sentido, os mecanismos de avaliação de riscos previstos na Portaria 84/96, guardam um enorme potencial de ação para os técnicos responsáveis pelo gerenciamento dos agrotóxicos.

Mas o avanço mais concreto, no sentido de utilizar o procedimento de avaliação de riscos como ferramenta para tomada de decisão, foi a assinatura do Termo de Cooperação $n^{\circ}$ 002449/3, publicado no DOU de 31/01/1996, entre o IBAMA e a Empresa Brasileira de Pesquisa Agropecuária - EMBRAPA (IBAMA, 2004). Este Termo prevê a execução de atividades que viabilizem o estabelecimento e a implementação de diretrizes sobre legislação, regulamentação e metodologias de avaliação de risco, e de impacto ambiental de agrotóxicos e afins. Apesar de ser uma iniciativa com alto potencial de geração de resultados, não foram identificados até o momento, trabalhos neste sentido.

Em 1997, o Ministério da Saúde publicou o "Manual de Vigilância da Saúde de Populações Expostas a Agrotóxicos”, resultado do trabalho realizado em áreas piloto de cinco estados - Bahia, Minas Gerais, Paraná, Rio de Janeiro e São Paulo, entre abril de 1995 a abril de 1996, com o objetivo de prestar orientação aos estados e municípios na implantação do Sistema de Vigilância da Saúde de Populações Expostas a Agrotóxicos (OPAS, 1996).

O Sistema de Vigilância visa conhecer o perfil de morbimortalidade relativo à exposição a esses produtos e ser um instrumento para o planejamento, organização, 
desenvolvimento a avaliação das ações pelos serviços de saúde, bem como normatização de atividades técnicas correlatas. O trabalho levou à definição de uma metodologia implantada em todo o território nacional, adotado pelo Sistema de Informações de Agravos de Notificações (SIAN), estabelecido pelo Centro Nacional de Epidemiologia (CENEPI) e pelo Departamento de Informática do Sistema Único de Saúde (DATASUS) (OPAS, 2004).

Também em 1997, o Ministério da Agricultura regulamentou o registro de agrotóxicos destinados às culturas hortículas, frutíferas e de jardinagem e o uso de produtos semioquímicos (feromônio, alomônio e cairomônio). O IBAMA publicou, no mesmo ano, na portaria sobre os procedimentos para registro de agentes biológicos, ressaltando que as informações e os testes solicitados deveriam subsidiar a avaliação de risco destes agentes.

Em 1998, o Ministério da Saúde cancelou a autorização para uso como domissanitário de vários produtos organoclorados - Aldrin, B.H.C., Clorobenzilato, DDT, Endrin, Heptacloro, Lindano, Paration e pentaclorofennol, utilizados em campanhas de saúde pública.

Em 1998, foi aprovada a Lei 9.605 - Lei de Crimes Ambientais, regulamentada pelo Decreto 3179/99. Este Decreto determina multas relativas ao gerenciamento dos agrotóxicos, nos artigos 57 e 58, como se apresenta:

Art. 57. “....deixar de apresentar aos órgãos competentes, as inovações concernentes aos dados fornecidos para o registro de agrotóxicos, seus componentes e afins",

Art. 58. “....deixar de constar de propaganda comercial de agrotóxicos, seus componentes e afins em qualquer meio de comunicação, clara advertência sobre os riscos do produto à saúde humana, aos animais e ao meio ambiente...." (BRASIL, 1999).

Em janeiro de 1999, foi criada a Agência Nacional de Vigilância Sanitária ANVISA, por meio da Lei $n^{\circ}$ 9.782/99, como uma autarquia sob regime especial, vinculada ao Ministério da Saúde e com uma Gerência-Geral de Toxicologia (GGTOX) responsável, dentre outras atividades, pela avaliação toxicológica dos agrotóxicos (BRASIL, 1999). 
Como conseqüência imediata da reestruturação no setor saúde, em 1999, foram publicadas três resoluções da ANVISA relacionadas aos agrotóxicos. A Resolução RDC $n^{0} 5$ suspendeu a aprovação e a avaliação toxicológica para registro de novas formulações de produtos agrotóxicos com mistura de ingredientes ativos considerados potencialmente carcinogênicos (ANVISA, 1999a); e as outras duas resoluções, RDC nº 6 e 7 (ANVISA, 1999b, 1999c), suspenderam a aprovação e a avaliação toxicológica para registro de novas formulações e misturas de produtos técnicos com os princípios ativos ALACHLOR, PARATION METÍLICO e METAMIDOFÓS, e colocou os produtos técnicos em processo de reavaliação toxicológica.

No ano 2000, a ANVISA publicou sete resoluções, quatro delas alterando o posicionamento técnico da Agência sobre substâncias químicas, ou seja, publicando novas monografias de substâncias da "Relação de Substâncias com Ação Tóxica sobre Animais ou Plantas, cujo registro pode ser Autorizado no Brasil, em Atividades Agropecuárias e Produtos Domissanitários". A alteração teve como finalidade incluir a autorização para o emprego como agropecuários de LAMBDACYHALOTHRIN, INDOXACARB, TRIADIMENOL e TEPRALOXIDIM. A Resolução n $n^{\circ}$ 98/2000 incluiu o LINDANO na lista das substâncias de uso proscrito no Brasil, ressaltando que permanecia autorizado o seu uso como preservativo de madeira e que o controle é do IBAMA (ANVISA, 2000c).

A Resolução $n^{\circ}$ 44/2000, da ANVISA, alterou itens da Portaria MS n 3/1992, relacionada às "Diretrizes e orientações referentes à autorização de registros, renovação de registro e extensão de uso de produtos agrotóxicos e afins", incluindo alterações de cunho burocrático relacionadas ao controle do registro dos produtos, e a atualização dos modelos de relatórios de estudos de resíduos de agrotóxicos, para harmonizar com as normas Codex/FAO (ANVISA, 2000a).

Por meio da Resolução $n^{0}$ 104/2000, a ANVISA passa a aceitar informações científicas reconhecidas de estudos de toxicidade em médio prazo; estudos de toxicidade de longo prazo/carcinogenicidade; estudos sobre o efeito sobre a reprodução e a prole em duas gerações sucessivas; estudos de teratogênese; estudos de neurotoxicidade tardia e; estudos de metabolização e excreção. Estes estudos 
subsidiam a avaliação toxicológica de produtos que contenham princípios ativos de uso corrente no País, mas não é excluída a possibilidade de exigência da realização de estudos técnicos adicionais (ANVISA, 2000b).

O Ministério da Saúde publicou, também no ano 2000, a Portaria $\mathrm{n}^{\mathrm{o}} 1.469$ determinando padrões de potabilidade de água para consumo humano, incluindo vários agrotóxicos (MS, 2000). TOMITA (2004) destaca que, o fato de um maior número compostos agrotóxicos terem sido incluídos nesta Portaria, em relação à Portaria anterior, de 1990, é uma evidência de que o número de casos de intoxicação não intencional de agrotóxicos é alto e se configura em um sério problema para a qualidade da água. Em 2004, o MS publicou a Portaria 518, revogando a Portaria 1.469, mas não incluiu modificações significativas relacionadas aos agrotóxicos (MS, 2004).

Em 2000 foi publicada a Lei 10.167, alterando dispositivos da Lei $n^{\circ}$ 9.294/96 sobre restrições ao uso e à propaganda de vários produtos, entre eles os "defensivos agrícolas". Apesar da Lei dos Agrotóxicos já ter onze anos, o uso do termo defensivo ainda aparece nesta lei, o que denota a falta de entendimento entre os legisladores (BRASIL, 2000d).

Durante o ano 2000, os três ministérios responsáveis pelo registro de agrotóxicos publicaram a Lei no 9.974/00, conhecida como "Lei das embalagens de agrotóxicos", e alterando o artigo $6^{\circ}$ da Lei 7.802/89, e outros relacionados à embalagem (BRASIL, 2000b).

A lei das embalagens definiu que estas deveriam ser projetadas para que fossem mais seguras quanto à vazamentos, evaporação, perda ou alteração do conteúdo. A partir deste momento ficou autorizado o fracionamento e a reembalagem, desde que realizados por estabelecimentos credenciados ou pelas empresas produtoras e foi determinada a obrigatoriedade da devolução das embalagens vazias aos estabelecimentos comerciais em que foram adquiridos, podendo ocorrer esta devolução em postos ou centros de recolhimento autorizados. A tríplice lavagem ${ }^{7}$ das embalagens rígidas passou a ser obrigatória.

7 Após o uso, as embalagens das formulações líquidas consideradas vazias ainda retêm no seu interior uma certa quantidade do produto. A tríplice lavagem, ou seja, enxaguar três vezes a embalagem vazia 
Esta Lei define também as responsabilidades das empresas produtoras e comercializadoras pela destinação adequada das embalagens vazias após a devolução pelo usuário, e as responsabilidades administrativas, civis e criminais do usuário ou prestador de serviço, do comerciante e do produtor.

A Lei das embalagens foi regulamentada pelo Decreto $n^{\circ} 3.550 / 2000$ (BRASIL, 2000c) e é considerada como um avanço na proteção ambiental, uma vez que propõe diretrizes concretas e claras para a redução dos riscos de intoxicação humana e contaminação ambiental decorrentes das embalagens de agrotóxicos, abandonadas no campo ou em locais impróprios.

Em decorrência da Lei das embalagens, no ano 2000, foram feitas duas alterações no Decreto 98.816/90, ambas relacionadas às instruções sobre embalagens, rótulos e bulas.

Em 2001, ocorreu a publicação da Portaria Conjunta $n^{\circ}$ 1, da ANVISA e IBAMA, uma ação administrativa inédita, determinando a reavaliação toxicológica e ambiental dos produtos técnicos e formulados à base de BENOMIL e CARBENDAZIN (ANVISA, 2001). Esta reavaliação ocorreu por meio de uma Comissão Técnica integrada por representantes da ANVISA, IBAMA, Ministério da Agricultura e do Sindicato Nacional da Indústria de Produtos para Defesa Agrícola SINDAG.

Quanto ao carbendazim, foi suspenso o uso em determinadas culturas, estabelecido limites de impurezas e cancelada a autorização para a aplicação com equipamento pulverizador costal e manual. O registro do benomil foi cancelado por solicitação voluntária da empresa.

Ressalta-se que o fungicida Benomil, cujos testes em animais comprovaram ser potencialmente causador de malformações em bebês humanos (IPCS/INTOX, 1999), quando aplicado em ambientes aquosos, ou no solo, é rapidamente hidrolizado, se transformando no isocianoato de ter-butila e no fungicida Carbendazin (IPCS/INTOX, 1994). Desta forma, o cancelamento do registro do Benomil, com a seja menor que $0,01 \%$ (100ppm). [http://www.andef.com.br, acesso em Dez. 2004]. 
manutenção do registro do Carbendazim, é apenas uma questão comercial e não uma preocupação real com a proteção da saúde humana e do meio ambiente.

O Decreto 98.816/90 sofreu várias modificações ao longo de sua implementação, com vistas a adaptá-lo as novas demandas. Foram feitas alterações relacionadas, entre outras, à operações de recebimento, recolhimento e destinação de embalagens vazias, importação e comercialização de matérias-primas, ingredientes inertes e aditivos, rótulos e bulas.

Estas freqüentes modificações levaram a um processo de discussão sobre a sua total reformulação que culminou na publicação do Decreto $n^{\circ} 4.074$, em 4 de janeiro de 2002, sendo este o regulamento federal mais recente que regulamenta a Lei 7.802/89 e, por conseguinte, o que norteia todo o gerenciamento de agrotóxicos no Brasil, na atualidade (BRASIL, 2002a).

\section{O Decreto 4.074 de 4.1.2002.}

O novo Decreto alterou algumas definições, principalmente relacionadas à natureza da pessoa que lida com o produto (fabricante, formulador, manipulador, prestador de serviço, registrante do produto e titular do registro), à origem do produto (país de origem e país de procedência), e ao tipo de produto (impureza, novo produto, produto de degradação, produto técnico equivalente e produto formulado equivalente); e foram incluídas novas definições, como: equipamento de proteção individual (EPI), intervalo de reentrada, intervalo de segurança, limite máximo de resíduos (LMR), mistura de tanque, pré-mistura, venda aplicada, posto de recebimento e receita ou receituário.

Com relação aos procedimentos de registro, os três ministérios tiveram suas responsabilidades ligeiramente alteradas com a inclusão de novas atividades.

Coube ao Ministério da Agricultura:

- Avaliar a eficiência agronômica e conceder o registro, inclusive o Registro Especial Temporário - $\mathrm{RET}^{8}$, de agrotóxicos, produtos técnicos, pré-misturas e

8 RET - "ato privativo de órgão federal competente, destinado a atribuir o direito de utilizar um agrotóxico, componente ou afim para finalidades específicas em pesquisa e experimentação, por tempo determinado, podendo conferir o direito de importar ou produzir a quantidade necessária à pesquisa e experimentação" (Dec, 4.074, art 1º, Item XLIII) 
afins, atendidas as diretrizes e exigências dos Ministérios da Saúde e do Meio Ambiente, e;

- Registrar dos produtos destinados às florestas plantadas.

Coube ao Ministério da Saúde:

- Avaliar quanto à eficiência e conceder o registro, inclusive o RET, aos agrotóxicos e afins destinados ao uso em ambientes urbanos, industriais, domiciliares, públicos ou coletivos, ao tratamento de água e ao uso em campanhas de saúde pública, atendidas as diretrizes e exigências dos Ministérios da Agricultura e do Meio Ambiente;

- Estabelecer o intervalo de reentrada em ambiente tratado com agrotóxicos e afins, e;

- Monitorar os resíduos de agrotóxicos e afins em produtos de origem animal.

Os Ministérios da Agricultura e Saúde compartilham a responsabilidade pelo monitoramento de resíduos de agrotóxicos e afins em produtos vegetais.

Coube ao Ministério do Meio Ambiente:

- Avaliação quanto à eficiência e conceder o registro, inclusive o RET, dos agrotóxicos e afins destinados ao uso em ambientes hídricos, na proteção de florestas nativas e de outros ecossistemas, atendidas as diretrizes e exigências dos Ministérios da Agricultura e da Saúde.

Os Ministérios da Agricultura e Meio Ambiente compartilham a responsabilidade pelo registro de componentes, definidos como "princípios ativos, produtos técnicos, suas matérias-primas, ingredientes inertes e aditivos usados na fabricação de agrotóxicos e afins" (art. $1^{\circ}$ item VII), de acordo com diretrizes dos três órgãos federais.

O Decreto 4.074/02 realizou várias modificações nos procedimentos para gerenciamento de agrotóxicos, dentre elas podem ser destacadas:

- Foi incluída a referência à produto técnico e formulado "equivalente", cujo processo de registro deve ocorrer de acordo com os critérios publicados pela FAO e as normas complementares dos três órgãos. Em 2002 os três órgãos 
federais publicaram a Portaria Normativa $n^{0} 49 / 02$ com os critérios para determinação de equilavência e para a avaliação de produtos técnicos equivalentes (BRASIL, 2002b).

A questão da equilavência entre produtos, uma das mais fortes exigências presente nas negociações para harmonização da legislação com os países do MERCOSUL, implica na utilização de dados de uma empresa para analisar produtos de outra, por ser equivalente. Este fato gerou a discussão sobre a propriedade dos dados e o uso das informações submetidas aos órgãos federais para o registro, levando à publicação da Medida Provisória $n^{0}$ 69/2002, convertida na Lei $\mathrm{n}^{\mathrm{o}} 10.603$, de 17 de dezembro de 2002, que regulou a proteção contra o uso comercial desleal de informações relativas aos resultados dos testes ou outros dados não divulgados, mas apresentados às autoridades para o registro (BRASIL, 2002c).

- Criação do SIA - Sistema de Informações sobre Agrotóxicos, com a finalidade de interagir os órgãos envolvidos no registro; disponibilizar informações; permitir o acolhimento de dados sobre importação, exportação, produção, formulação e comercialização de agrotóxicos e afins e disponibilizar estas informações; manter cadastro de áreas autorizadas para pesquisa e experimentação com agrotóxicos; disponibilizar informações sobre tecnologias de aplicação e segurança no uso de agrotóxicos. Coube à ANVISA desenvolver o Sistema e colocar à disposição no seu site na internet ${ }^{9}$.

- Definição da possibilidade de priorizar o trâmite de produtos de baixa toxicidade e periculosidade, desde que solicitado e justificado pelo requerente, e aprovado pelos órgãos federais competentes (Art. 12).

- Concessão de registro apenas para produtos com ação tóxica menor ou igual à produtos já registrados, com os critérios de comparação estabelecidos em instruções normativas complementares dos três órgãos.

- Determinação de prazo para a elaboração de rotinas e procedimentos para a implantação da avaliação de riscos.

9 SIA: http://www.anvisa.gov.br/toxicologia/sia.htm 
- Proibição do registro de agrotóxicos para os quais não exista antídoto, sem a observação existente no Decreto 98.816/90 (....usados em concentrações comprovadamente não letais para os homens e animais.).

- Definição de que a desativação dos componentes deve ocorrer por meio de um processo que leve à minimização dos riscos à saúde humana e ao meio ambiente.

- Simplificação dos trâmites burocráticos para requerimento de cancelamento e impugnação de registro.

- Determinação de que as empresas importadoras, exportadoras, produtoras ou formuladoras devem adotar, para cada partida, codificação definida em anexo do Decreto, que deverá constar de todas as embalagens. As empresas devem fornecer aos órgãos federais e estaduais competentes, até 31 de janeiro e 31 de julho de cada ano, dados sobre a importação, exportação, produção, formulação e comercialização, de acordo com o modelo de relatório semestral apresentado.

- Definição de que o Ministério dos Transportes é o responsável pelas regras e procedimentos relacionados à atividade de transporte.

- Simplificação do procedimento de emissão do receituário, com a diminuição do numero de vias, e com a possibilidade de dispensa da exigência do receituário para os produtos de baixa periculosidade.

- Criação do CTA - Comitê Técnico de Assessoramento para Agrotóxicos (Art. 95), constituído por dois representantes de cada um dos três órgãos federais, designados pelo respectivo Ministro. O CTA é coordenado por um de seus membros, que prestará apoio técnico e logístico, com mandato de um ano, em sistema de rodízio.

O CTA é responsável por atividades de importância no controle dos agrotóxicos, tendo o poder de definir os rumos do gerenciamento destas substâncias no país.

Além de discutir a racionalização e harmonização dos procedimentos técnicocientíficos e administrativos nos processos de registro e adaptação de registro, o CTA deve propor sistemática para incorporação de tecnologia de ponta nos processos de análise, controle e fiscalização; analisar propostas de edição e alteração de atos 
normativos sobre as matérias tratadas no Decreto e sugerir ajustes e adequações; propor critérios de diferenciação de agrotóxicos, seus componentes e afins em classes, em função de sua utilização, de seu modo de ação e de suas características toxicológicas, ecotoxicológicas ou ambientais; assessorar os Ministérios responsáveis na concessão do registro para uso emergencial e no estabelecimento de diretrizes e medidas que possam reduzir os efeitos danosos desses produtos sobre a saúde humana e o meio ambiente; estabelecer as diretrizes a serem observadas no SIA, acompanhar e supervisionar as suas atividades; e manifestar-se sobre os pedidos de cancelamento ou de impugnação de agrotóxicos seus componentes e afins, conforme previsto no Decreto.

A CTA vem, de acordo com algumas atas tornadas publicadas na homepage da ANVISA $^{10}$, ocupando-se essencialmente da aprovação de produtos para uso emergencial.

As questões que não alcançam consenso no âmbito do CTA devem ser submetidas aos Ministros de Estado responsáveis pelas três áreas, para deliberação conjunta.

Além destas importantes atividades, o CTA é responsável pela elaboração de rotinas e procedimentos visando a implementação da avaliação de risco de agrotóxicos e afins no país. Mas, estes ainda não foram publicados, apesar do Decreto haver criado uma comissão, com prazo até dezembro de 2002, para elaboração e apresentação de propostas.

Após o Decreto 4.074/02, o Ministério da Agricultura publicou duas Instruções Normativas atualizando os nomes vulgares e científicos das pragas, para efeito de atualização de bulas, e determinou a retirada das indicações de mistura em tanque dos rótulos e bulas.

Em 2003, a ANVISA criou, por meio da Resolução RDC nº 119, o PROGRAMA de ANALISE de RESÍDUOS de AGROTÓXICOS em ALIMENTOS - PARA, com a finalidade de avaliar de forma contínua os níveis de resíduos de agrotóxicos em alimentos in natura, identificando os que excedem os limites máximos de resíduos (LMR) autorizados pela legislação (ANVISA, 2003). O programa, dentre outros objetivos, deve nortear ações especificas do sistema de vigilância sanitária.

$10 \mathrm{http}: / /$ www.anvisa.gov.br/toxicologia/comite/index.htm 
Neste ano de 2004, a ANVISA vem publicando Resoluções a respeito dos resultados das reavaliações iniciadas em 2002, como a Resolução RE nº 87, de 26/04/2004, que dá o prazo de 120 dias para as empresas adequarem os rótulos e bulas dos produtos reavaliados (ANVISA, 2004).

Do panorama apresentado é possível concluir que as políticas públicas voltadas para o gerenciamento dos agrotóxicos, apesar de serem passíveis de críticas, não podem ser consideradas um insucesso. Observa-se que, apesar de haver falha na implementação, a política causou o que SILVA e MELO (2000) chamaram de "efeito retroalimentador da implementação", ou seja, novas políticas foram orientadas, e continuam sendo de forma bastante rápida. A falha na implementação parece decorrer da clara falta de coordenação e cooperação interinstitucionais inerentes ao contexto organizacional brasileiro.

Cada País deve procurar seus próprios caminhos para o gerenciamento dos agrotóxicos. No caso do Brasil, um país cuja utilização de agrotóxicos é parte integrante do modelo de modernização da agricultura, este gerenciamento vem se aprimorando de forma bastante acentuada nos últimos 15 anos, após a promulgação da Lei 7.802/89. Entretanto, as estatísticas de intoxicações continuam indicando que é necessário investir em mecanismos mais efetivos de gerenciamento. Vários autores sugerem restrições de ordem técnica, administrativa, econômica e legal, incluindo restrições na comercialização e uso com taxações e controle de preços, em detrimento dos tradicionais mecanismos de comando e controle, praticamente os únicos utilizados até o momento no gerenciamento destas substâncias (GARCIA, 2001; ALVES FILHO, 2002; SOBREIRA e ADISSI, 2003).

Alguns estudos destacam a necessidade de aprofundar a discussão da política de gerenciamento de agrotóxicos, e não apenas estudos de laboratório, metodologias de análise ou de resíduos.

Observando o número de produtos altamente tóxicos retirados do mercado, via proibição, podemos dizer que o trâmite interministerial proposto na legislação até o momento redundou em poucos benefícios para a sociedade, tendo em vista o potencial que a legislação em vigor dá ao poder público para atuar, apesar da 
legislação também já ter propiciado a restrição de vários produtos agrotóxicos, conforme se observa na Tabela 3.

Além do benomil e carbendazim, reavaliados em 2001, entre 2002 e 2003 vários produtos agrotóxicos, suspeitos de provocarem efeitos adversos à saúde humana e que tinham suas avaliações toxicológicas emitidas há alguns anos, foram reavaliados e sofreram restrição em vários aspectos (ANVISA, 2002a).

Como resultado deste trabalho, a importação do HEPTACLORO foi suspensa e foi imposto um rígido controle sobre o estoque do produto mantido pela empresa fabricante; foram solicitados estudos de degradação em solos brasileiros para o herbicida organoarsênico MSMA, e foi proposta a realização de estudo de avaliação de risco carcinogênico para humanos. Quanto ao TIOFANATO METÍLICO, foram solicitados novos estudos para aprofundar a reavaliação.

Para o DICOFOL, foi solicitado à empresa que apresentasse um programa de distribuição e controle do produto, para evitar desvios de uso, e estudos sobre resíduos e processo de síntese do produto, visto sua importância na avaliação da toxicidade. Um dos motivos da reavaliação foi a possibilidade das formulações de Dicofol conter DDT como impureza, em níveis acima do permitido.

Desta forma, encontram-se totalmente proibidos o Aldrin, Benomil, Clorobenzilato e o Dodecacloro. Os agrotóxicos carbendazin, clopirifós, heptacloro, lindano e procloraz estão autorizados apenas para uso como preservativos de madeira. Os preservativos de madeira organoclorados só podem ser comercializados por meio da "venda direta", ou seja, não podem ser vendidos em estabelecimentos comerciais. 
TABELA 3. Agrotóxicos com restrições, ou proibidos, no país

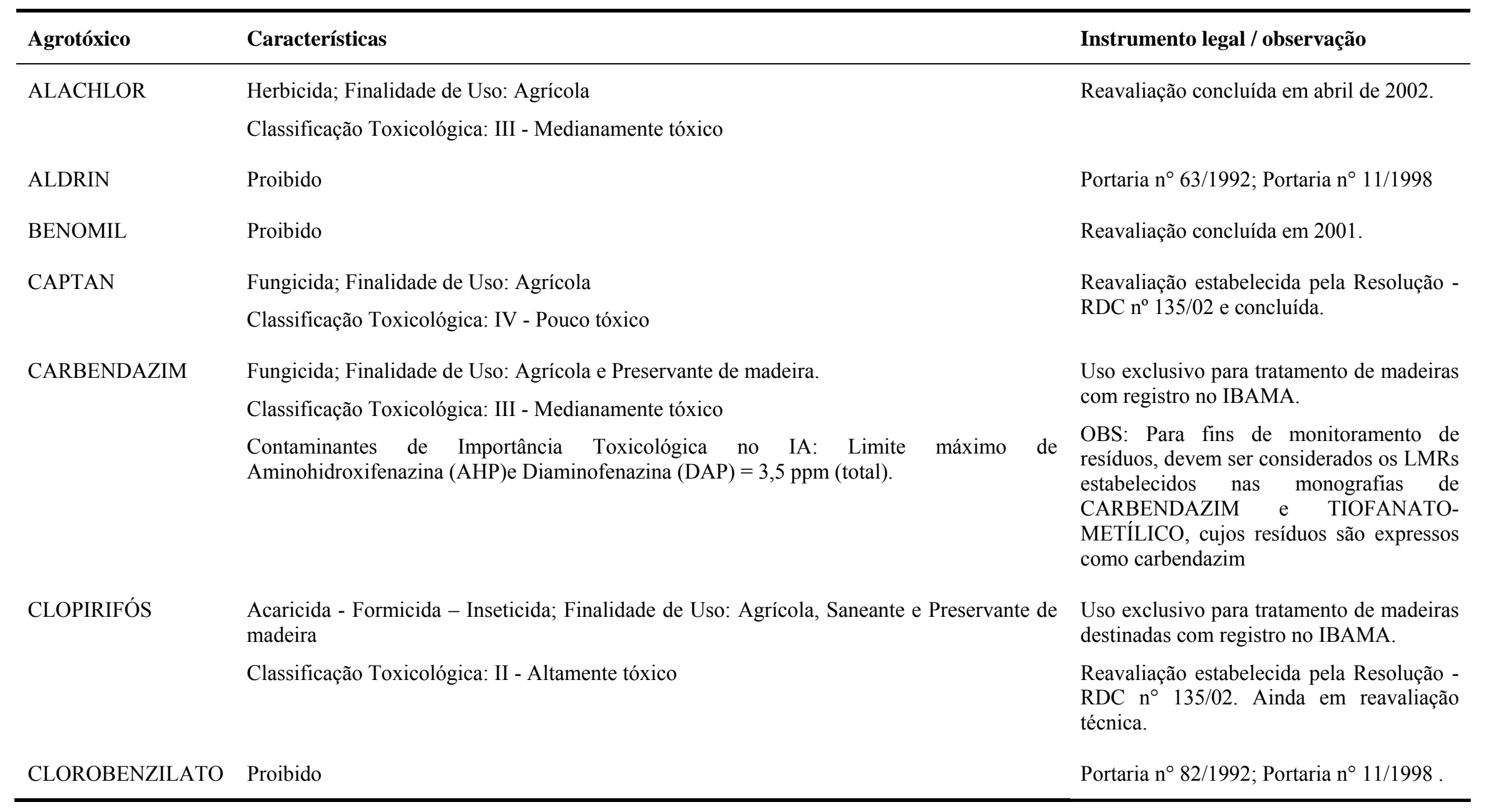




\begin{tabular}{|c|c|c|}
\hline Agrotóxico & Características & Instrumento legal / observação \\
\hline CLOROTALONIL & $\begin{array}{l}\text { Fungicida; Finalidade de Uso: Agrícola } \\
\text { Classificação Toxicológica: III - Medianamente tóxico } \\
\text { Contaminantes de Importância Toxicológica no IA: Limite máximo de Hexaclorobenzeno } \\
(\mathrm{HCB})=100 \mathrm{ppm} \text {. }\end{array}$ & $\begin{array}{l}\text { Reavaliação estabelecida pela Resolução - } \\
\text { RDC no } 135 / 02 \text {. Ainda em reavaliação } \\
\text { técnica. }\end{array}$ \\
\hline DICOFOL & $\begin{array}{l}\text { Acaricida; Finalidade de Uso: Agrícola } \\
\text { Classificação Toxicológica: II - Altamente tóxico } \\
\text { Contaminantes de Importância Toxicológica no IA: Limite máximo de DDT-r (DDT, DDE, } \\
\text { DDD) }=1.000 \text { ppm. }\end{array}$ & $\begin{array}{l}\text { Reavaliação estabelecida pela Resolução - } \\
\text { RDC n } 135 / 02 \text { e concluída. }\end{array}$ \\
\hline DODECACLORO & Proibido & Portaria $\mathrm{n}^{\circ}$ 91, de 30 de novembro de 1992 \\
\hline EPOXICONAZOLE & $\begin{array}{l}\text { Fungicida; Finalidade de Uso: Agrícola } \\
\text { Classificação Toxicológica: III - Medianamente tóxico }\end{array}$ & $\begin{array}{l}\text { Reavaliação estabelecida pela Resolução - } \\
\text { RDC n }{ }^{\circ} 135 / 02 \text { e concluída }\end{array}$ \\
\hline FOLPET & $\begin{array}{l}\text { Fungicida; Finalidade de Uso: Agrícola } \\
\text { Classificação Toxicológica: IV - Pouco tóxico }\end{array}$ & $\begin{array}{l}\text { Reavaliação estabelecida pela Resolução - } \\
\text { RDC n } 135 / 02 \text { e concluída. }\end{array}$ \\
\hline HEPTACLORO & Finalidade de Uso: Preservativo de madeira & $\begin{array}{l}\text { Importação suspensa e a imposição de } \\
\text { controle do estoque pela empresa } \\
\text { fabricante. Autorizado apenas "Venda } \\
\text { Direta". }\end{array}$ \\
\hline LINDANO & $\begin{array}{l}\text { Inseticida; Finalidade de Uso: Preservante de madeira } \\
\text { Classificação Toxicológica: II - Altamente tóxico }\end{array}$ & $\begin{array}{l}\text { Uso exclusivo para tratamento de madeiras } \\
\text { com registro IBAMA. Autorizado apenas } \\
\text { "Venda Direta". }\end{array}$ \\
\hline
\end{tabular}




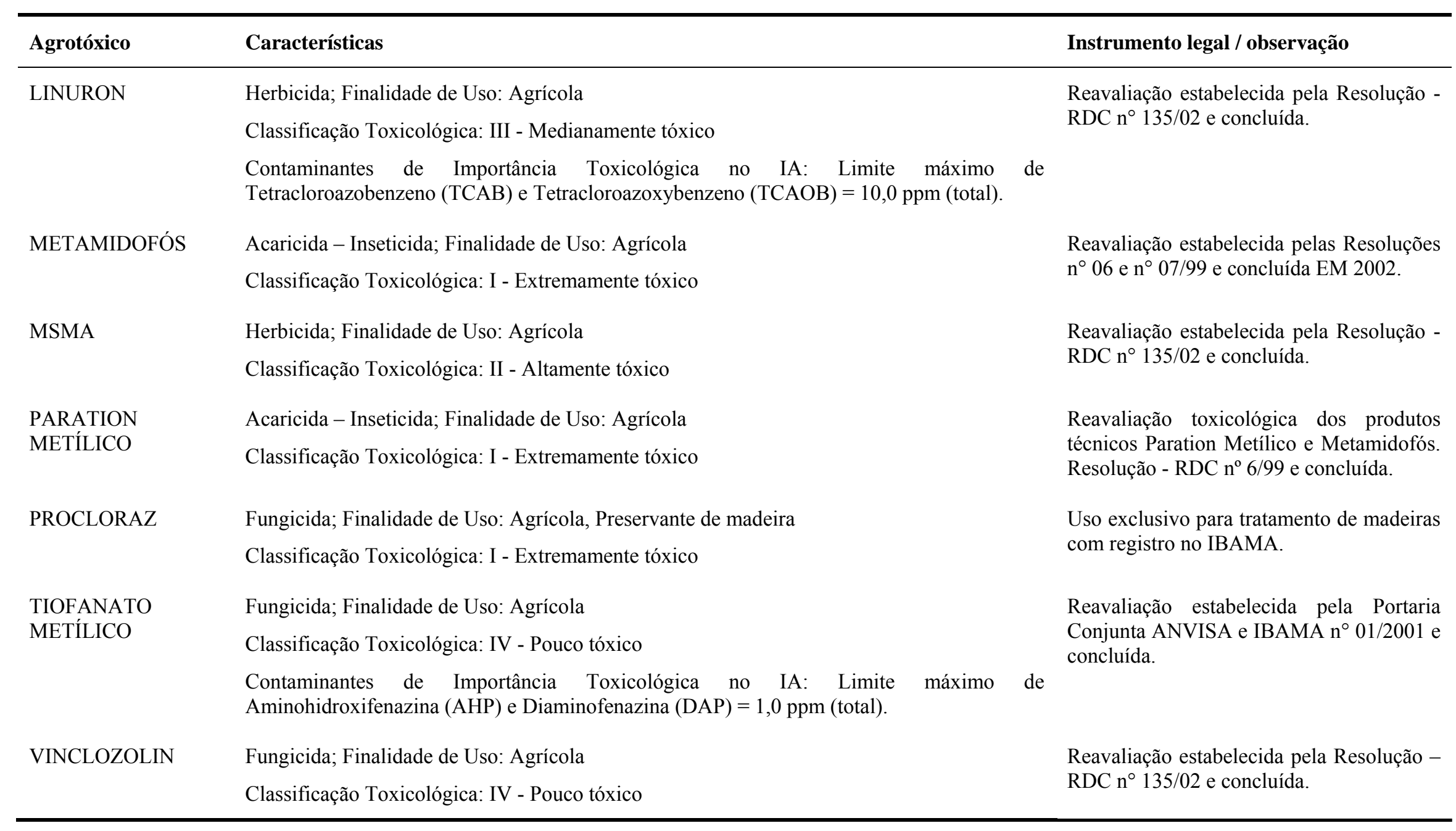

Fonte: SIA - Sistema de Informações sobre Agrotóxicos (ANVISA, 2002b). Ref: Portaria $n^{\circ}$ 63/1992 (D'AMATO et al. 2002) ; Portaria $n^{\circ} 11 / 1998$ (MS, 1998); Portaria $n^{\circ}$ 91/1992 (MAPA, 1002); Resolução - RDC n 135/02 (ANVISA, 2002c); Resoluções Nº 6 e 7/ 1999 (ANVISA, $\left.1999 b, c\right)$; Portaria nº 82/1992 (MAPA, 1992a); Portaria Conjunta ANVISA e IBAMA nº 01/2001 (ANVISA, 2001). 


\section{AVALIAÇÃo DE RISCO}

Neste capítulo é discutido o uso da avaliação de riscos no gerenciamento de substâncias químicas, começando com os conceitos de risco e de avaliação de risco, e os princípios que regem a avaliação de riscos de substâncias químicas e de agrotóxicos.

\subsection{O Conceito de Risco}

Com relação à origem do termo risco, SPINK (2001) a palavra risco surgiu na língua catalã, no século XIV, nas línguas latinas, no século XVI, e, no século XVII, nas anglo-saxônicas.

Para BERNSTEIN (1997), o conceito científico de risco tem origem no século XVII, quando foi desenvolvida a base de cálculo matemático de chances no contexto das apostas, com risco significando a probabilidade de um evento ocorrer combinada com a magnitude de perdas e ganhos (NARDOCCI, 1999).

AYRES (1997) cita que, na epidemiologia, o termo surgiu no século passado, nos Estados Unidos, mais especificamente nos anos 20, como indicativo de ameaça ou perigo. O termo foi consolidado quantitativamente após a Segunda Guerra Mundial com a necessidade de conhecer e avaliar perdas acidentais, para redução de gastos com prêmios de seguros (PEREIRA, 1998).

No campo da saúde pública o risco foi a base para a privatização dos serviços de saúde, nos Estados Unidos e, na área de segurança industrial, foi a base para o cálculo de perdas com acidentes industriais e a redução dos custos dos seguros industriais.

Segundo SPINK (2001) a conceituação de risco decorre do uso da estatística como ciência do estado (do latim status, que quer dizer estado ou condição), pelos alemães, nos séculos XVIII e XIX, para a coleta e a classificação de fatos relevantes para a administração. No século XIX a estatística passou a ser utilizada em ciência sanitária. Em meados do século XX, o conceito de risco foi formalizado e as técnicas de cálculo dos riscos foram aprimoradas. 
O avanço do cálculo de probabilidade permitiu que a coleta de dados se tornasse um instrumento fundamental de governo e, na década de 50, a análise de riscos passou a ser utilizada no contexto dos riscos associados à energia nuclear e bélica.

A complexidade em conceituar risco pode ser observada pela vasta bibliografia identificada abordando a questão (NRC, 1983; RODRICKS, 1992; BERNSTEIN, 1997; MACHADO e MINAYO, 1997; PEREIRA, 1998; NARDOCCI, 1999; GARCIA, 2000; BRUSON, 2001; SPINK, 2001; LIEBER e ROMANO-LIEBER, 2002; MINAYO e MIRANDA, 2002; HACON 2003, CHRISTENSEN et al. 2003; LIEBER e ROMANO-LIEBER, 2003; dentre outros autores) em diferentes áreas da ciência.

Conforme cita LIEBER e ROMANO-LIEBER (2002) a tentativa de conceituar risco, que pressupõe um conceito inerentemente dúbio, é arriscada, pois implica em um embate contra a onipotência da racionalidade científica.

CHRISTENSEN et al. (2003) fizeram um levantamento dos conceitos associados a risco, utilizados em ciências, explicando e discutindo diferentes visões e aplicações dos termos, e concluíram que a terminologia associada à identificação, estimativa, regulação e comunicação de riscos é fonte de ambigüidade e, às vezes, controvérsias. Segundo os autores, os termos fundamentais da ciência de risco, utilizados para descrever e caracterizar processos físicos, químicos ou biológicos, nas relações de causa-efeito devido a uma fonte de risco, são mais bem estabelecidos do que a terminologia relacionada a risco em outras áreas da ciência, como sociologia e política.

PEREIRA (1998), citou em seu trabalho diversos autores e entidades que conceituam riscos e concluiu que as conceituações são divergentes. NARDOCCI (1999) também destacou esta problemática, e ressaltou que diferentes áreas da ciência, como psicologia, economia, ciências atuariais (relacionada à estatística), ciências médicas e biológicas e engenharia, são usuárias do termo, o que contribui para esta divergência. A Sociedade de Análise de Riscos - SRA (sigla em inglês), conceitua risco como o potencial de ocorrência de um efeito não desejável para a vida humana, saúde, propriedade ou meio ambiente (SRA, 2003). 
A CETESB, no contexto da análise de acidentes industriais, define risco como uma função de probabilidade de ocorrência de um evento indesejado e suas conseqüências, em termos de dano ao patrimônio, ao homem e ao meio ambiente (SERPA, 2000).

Em epidemiologia, risco pode ser definido como a probabilidade dos membros de uma determinada população desenvolver uma dada doença, ou evento relacionado à saúde, em um período de tempo (Almeida Filho, 1992, apud, BRUSON, 2001).

Em toxicologia, risco é conceituado como a probabilidade de uma substância química atingir uma população, sob condições reais de exposição, e produzir efeitos adversos em sua saúde (RODRICKS, 1992).

Por ser uma probabilidade, o risco é expresso como uma razão adimensional e seu valor varia de 0 (zero), que denota certeza absoluta de que não existe risco, o que nunca pode ser demonstrado, até 1,0 (um), que é a certeza absoluta da ocorrência do dano.

SPINK (2001) relata que o uso do termo na epidemiologia levou a formação de um campo denominado gestão de riscos, "resultado do casamento entre o cálculo de probabilidades e a herança da função política da estatística", gerando sofisticados modelos de análise de riscos.

Segundo NARDOCCI (1999), apesar das diferenças, todas as definições sempre associam risco a uma probabilidade de ocorrência de um evento e a magnitude de suas conseqüências, variando apenas a metodologia de avaliação e a interpretação dessas grandezas, a depender do tipo de risco estudado, por exemplo, se epidemiológico, tecnológico, ambiental ou outro.

Deve ser destacado que existe uma diferença fundamental entre os conceitos de risco e de perigo, apesar de ser comum encontrar citações onde os termos são utilizados indistintamente, tanto em trabalhos de cunho acadêmico como em documentos oficiais de governo.

No levantamento de termos utilizados para descrever e caracterizar riscos de processos físicos, químicos e biológicos, realizado por CHRISTENSEN et al. (2003), foi encontrado unanimidade, entre as fontes pesquisadas, quanto ao fato de que a 
diferença fundamental entre os termos perigo e risco, é que o primeiro lida com a possibilidade, ou potencial, de efeitos adversos sem incluir a probabilidade de uma conseqüência. Os autores definem perigo como a propriedade inerente de uma fonte de risco potencialmente causadora de conseqüências ou efeitos adversos.

No contexto específico das substâncias químicas, naturais e sintéticas, RODRICKS (1992) afirma que todas são tóxicas e produzem efeitos adversos sob alguma condição de exposição, ou seja, a toxicidade é uma propriedade intrínseca das substâncias químicas e o que varia é o risco associado à probabilidade da substância vir a atingir um alvo (órgão), em uma concentração determinada (efetiva).

Segundo o IPCS (1998), o risco de uma substância química é determinado não apenas pela toxicidade da substância, mas também pela concentração e a quantidade a qual as pessoas e o meio ambiente estão expostos, por qual rota e por qual via (oral, inalatória ou dérmica), por quanto tempo e com que freqüência.

De acordo com a UNEP/IPCS (1999), perigo significa uma descrição mais qualitativa dos efeitos adversos, uma característica ou propriedade inerente a uma substância química, que pode levar a danos; enquanto risco refere-se a uma medida quantitativa da probabilidade de certo efeito adverso ocorrer em um grupo de pessoas, ou em um determinado ecossistema, como resultado da exposição.

No Brasil, a legislação sobre substâncias químicas apresenta vários exemplos da confusão entre os termos risco e perigo (NARDOCCI, 1999), mas observa-se que, o esforço da comunidade científica em desenvolver teorias e aplicar metodologias para estimar e avaliar os riscos de maneira quantitativa e probabilística tem sido fundamental para esta distinção e tem contribuído para a redução destas ocorrências.

Para fins deste trabalho, perigo (físico, químico ou biológico) é a propriedade intrínseca de uma atividade, instalação ou substância, enquanto risco está sempre associado à probabilidade de acontecer o evento indesejado, relacionado à esta atividade, instalação ou substância.

A partir deste conceito nos defrontamos com uma questão rotineira na sociedade atual, globalizada e caracterizada por mudanças aceleradas, o que facilita a disseminação de qualquer fator de risco. A probabilidade de acontecer um evento indesejado pressupõe conhecimento dos padrões de regularidades - freqüência - que 
permitam estabelecer conexões entre os acontecimentos. $\mathrm{Na}$ sociedade contemporânea estes padrões de regularidade estão fragmentados e não permitem a sua utilização como vetor de previsibilidade.

Segundo SPINK (2001) a transição para a sociedade de risco, a crença na possibilidade de controlar o futuro a partir da agregação e análise de séries de informações, passou a ser questionada frente à natureza sistêmica e globalizada dos riscos.

Esta falta de referencial de regularidade faz com que qualquer diagnóstico que se produz baseado em riscos, seja no âmbito político ou em um processo técnico de decisão, pode vir a colocar os envolvidos em uma situação de insegurança. Um dos fatores que contribui para isto é que, avaliar um risco envolve um grande número de julgamentos profissionais, tanto técnicos como de valores, além de suposições plausíveis e muitas considerações devido à falta de informação (KOLLURU e BROOKS, 1996).

CALDAS (1999) afirma que avaliar riscos implica em lidar com elevada incerteza, que varia de acordo com o grau de importância que o público em geral, e os grupos formadores de opinião dão, ao fenômeno ou evento.

Além disso, o uso da probabilidade como base para tomada de decisão altera o padrão tradicionalmente utilizado pelo Estado, cujo enfoque é essencialmente determinístico (FERRIER, et al. 2002).

A elevada incerteza advém da falta do referencial de regularidade devido tanto da variabilidade científica, ou seja, da qualidade, validade e disponibilidade da informação técnica utilizada para o diagnóstico, quanto do grau de influência dos interesses políticos e sociais na questão, além do grau de percepção quanto ao risco, do grupo tomador de decisão.

A percepção de risco pela sociedade é variável, dependente das suas características sociais, políticas e culturais e interfere na decisão sobre o valor do risco a ser aceito. Segundo a UNEP/IPCS (1999), a discussão sobre o que é um risco aceitável é complexa e a decisão sobre a aceitabilidade geralmente é deixada para a sociedade ou para o indivíduo, de acordo com a situação em questão. 
NARDOCCI (1999) afirma que uma forma de assegurar a aceitabilidade do risco é trabalhar a aceitabilidade do processo, uma vez que aceitar o processo é parte da aceitação dos resultados, viabilizando a participação dos diferentes atores sociais no processo, especialmente dos atores diretamente afetados.

Apesar da incerteza nos processos quantitativos, esta é a mais importante ferramenta utilizada nos processo de tomada de decisão, de maneira geral, e no gerenciamento de substâncias químicas em particular e, portanto, o resultado da avaliação de riscos apesar de possuir substancial incerteza, deve ao mesmo tempo inspirar confiança tanto dos políticos quanto do público.

\subsection{O Processo de Avaliação de Risco (AR)}

Para COWELL et al. (2002) a avaliação de risco tem raízes nas abordagens da teoria da probabilidade e nos métodos utilizados, há centenas de anos, para identificar ligações casuais entre efeitos adversos à saúde e atividades consideradas perigosas.

A Sociedade de Análise de Riscos, no seu glossário, define "avaliação de risco" como um processo de resgate de informações relacionadas aos níveis aceitáveis de risco, e/ou níveis de risco, para um indivíduo, grupo, sociedade ou o meio ambiente (SRA, 2003).

A avaliação de riscos consiste na identificação dos efeitos adversos potenciais do fenômeno em análise, da estimativa da sua probabilidade e da magnitude dos efeitos, é o processo de definição dos componentes do risco em termos precisos e, geralmente, quantitativos (SPINK, 2001).

Com relação à sua finalidade, COWELL et al. (2002) afirmam que o objetivo principal da avaliação de riscos é estimar a probabilidade e a severidade do dano associado com um produto, processo, atividade, agente (poluente) ou evento, e comparar com critérios de aceitabilidade, que dependem de análise custo-benefício, de negociação social, de preferências individuais, de precedentes legais ou de estudos de risco já realizados.

A utilização da avaliação de risco no gerenciamento das substâncias químicas tornou-se mais freqüente após graves acidentes industriais, ocorridos na década de 
70. Nesta época, o conceito foi utilizado para abordagens que visavam a prevenção de acidentes no processo industrial, no interior da planta da fábrica.

Um exemplo clássico é o acidente de Seveso, ocorrido em 1976, na Itália, quando a explosão de uma planta industrial contaminou uma extensa área com a dioxina TCDD (2,3,7,8-tetraclorodibenzo-p-dioxina ou, tetra cloro dibenzo p-dioxina ou, 2,3,7,8-TCDD). Este acidente gerou uma intensa discussão na Comunidade Econômica Européia, culminando com a aprovação da Diretiva 82/501 - Diretiva de Seveso, que define e regulamenta os riscos de uma unidade industrial e propõe a análise e a comunicação, às autoridades e à comunidade, dos riscos inerentes ao processo industrial.

Em 1983, uma publicação do Conselho da Academia Nacional de Ciências dos Estados Unidos - NRC (sigla em inglês), discutiu a aplicação da avaliação de riscos em nível governamental e concluiu que esta ferramenta é uma base efetiva para definir os efeitos da exposição de indivíduos ou populações a materiais ou situações perigosas (NRC, 1983). Segundo o NRC, a finalidade da avaliação de riscos é descrever as conseqüências à saúde decorrentes da exposição às substâncias perigosas.

Em 1988, as Nações Unidas lançou o Programa APELL - Awareness and Preparedness Emergencies at the Local Level, visando a redução das taxas de acidentes e a preparação de planos de respostas para emergências. Em 1993, a Organização Internacional do Trabalho - OIT, publicou Diretiva dirigida à identificação do risco, a planos de emergência e a disseminação de informações (BATTERMAN e KOVACS, 2003).

Como o emprego da avaliação de riscos tem origem na prevenção de grandes acidentes industriais, a maioria dos estudos de avaliação de riscos disponibilizados, relacionados às substâncias químicas trata da avaliação dos riscos em empreendimentos industriais, cujo foco é a prevenção e gerenciamento de grandes acidentes. Esta análise é realizada em cinco etapas (CETESB, 2000):

- Caracterização do empreendimento e da região;

- Identificação dos perigos; 
- Análise de conseqüências e de vulnerabilidade;

- Cálculo e avaliação de riscos e;

- Programa de gerenciamento de riscos.

No Brasil, a análise de risco de empreendimentos industriais, realizada em instalações que apresentam riscos de acidentes maiores, tem sido empregada no licenciamento ambiental de empreendimentos há vários anos. O Estado de São Paulo foi pioneiro na utilização da análise de riscos para esta finalidade (SERPA, 2000). Atualmente é uma prática adotada por muitos outros Estados e pelo IBAMA.

O desenvolvimento da avaliação de risco como uma abordagem interdisciplinar [hybrid discipline] é relativamente nova, segundo COWELL et al. (2002), ocorreu por volta de 1950, e desde então vem sendo cada vez mais utilizada como suporte para a tomada de decisão tanto em organizações comerciais como governamentais.

Atualmente, a avaliação de riscos é fundamental para o adequado gerenciamento das substâncias químicas, pois tem como objetivo identificar, caracterizar e quantificar os potenciais efeitos adversos para o ser humano e o meio ambiente, exposto a uma substância ou a uma mistura (IPCS, 1998).

O emprego da ferramenta para fins regulatórios relacionados à substâncias perigosas, incrementou a avaliação de riscos de substâncias químicas individuais, principalmente nos países desenvolvidos.

GARCIA (2000) cita que, desde 1980, esta ferramenta vem sendo empregada em diferentes países visando à regulação do uso de produtos químicos. Historicamente, a USEPA é pioneira no desenvolvimento e aplicação de metodologias de avaliação de riscos de substâncias químicas para fins de tomada de decisão governamental. A União Européia também utiliza esta ferramenta e, segundo COWELL et al. (2002), ela se tornou fundamental na regulação de produtos químicos e radioativos.

Não existe uma metodologia padrão para a avaliação de riscos de substâncias químicas, existem referenciais metodológicos essencialmente baseados na metodologia adotada para análise de risco de materiais radioativos.

Por isso, a necessidade de desenvolver, aprimorar e implementar, metodologias de avaliação de riscos de substâncias químicas é ressaltada em artigos científicos 
nacionais e internacionais, bem como em foro de discussões relacionadas à segurança química, seja em nível nacional, regional ou internacional, e colocada como sendo uma atividade fundamental (IPCS/UNITAR, 1998; UNITAR, 1999; CNUMAD, 2001 e outros).

A harmonização das metodologias de avaliação de riscos, em nível regional e internacional, também tem sido tópico de debate em vários foro, e as principais dificuldades encontradas são as diferenças nos requisitos solicitados para a avaliação, a diferença na disponibilidade de dados nos países, a variabilidade nas características que influenciam o grau de exposição e os critérios de tomada de decisão. PITTINGER et al. (2003), citam que a diversidade de ferramentas para identificar o risco de uma substância pode dificultar o entendimento da questão em nível internacional.

A avaliação de riscos dá suporte à tomada de decisão do governo quanto à aprovação, ou não, de requerimento de registro, ou similar, antes da entrada no comércio, ou após a entrada no comércio, durante a reavaliação, de agrotóxicos, ou outros produtos.

\subsection{Avaliação de Riscos de Substâncias Químicas}

Segundo a SRA a avaliação de risco é um processo de resgate de informações relacionadas aos níveis aceitáveis de risco (SRA, 2003), demandando a identificação de efeitos adversos de determinado fenômeno e a estimativa da probabilidade e magnitude destes efeitos. Por isso, a avaliação dos riscos de substâncias químicas envolve um esforço multidisciplinar, que visa a organização e análise de informações científicas disponíveis, relacionadas aos efeitos adversos de uma substância química qualquer, com a finalidade de estabelecer suas probabilidades e magnitudes, e permitir ao gestor, principalmente, promover a redução da freqüência dos eventos adversos identificados.

Todas as classes de substâncias químicas têm os riscos avaliados tendo como referência metodológica a proposta do Conselho da Academia Nacional de Ciências dos Estados Unidos - NRC, publicada no livro conhecido como "livro vermelho" [red book] (NRC, 1983). Ela propõe um processo de avaliação composto por cinco etapas, culminando em uma proposta de gerenciamento dos riscos, visando a redução 
ou, se possível, eliminação dos efeitos adversos identificados. A Figura 4 reproduz, de forma esquemática, a proposta do Conselho.

As cinco etapas da proposta do NRC, que é utilizada como referência por praticamente todos os países, são: (1) Identificação do Perigo, (2) Avaliação da Dose-Resposta e, (3) Avaliação da Exposição Humana. Na seqüência as informações destas etapas são consolidadas em uma etapa denominada (4) caracterização de risco, que leva à elaboração do (5) Programa de Gerenciamento/Redução dos riscos, onde são discutidas as alternativas políticas e técnicas para prevenir, reduzir e controlar os riscos.

FIGURA 4 Etapas da avaliação de risco, baseada na proposta do NRC (1983)

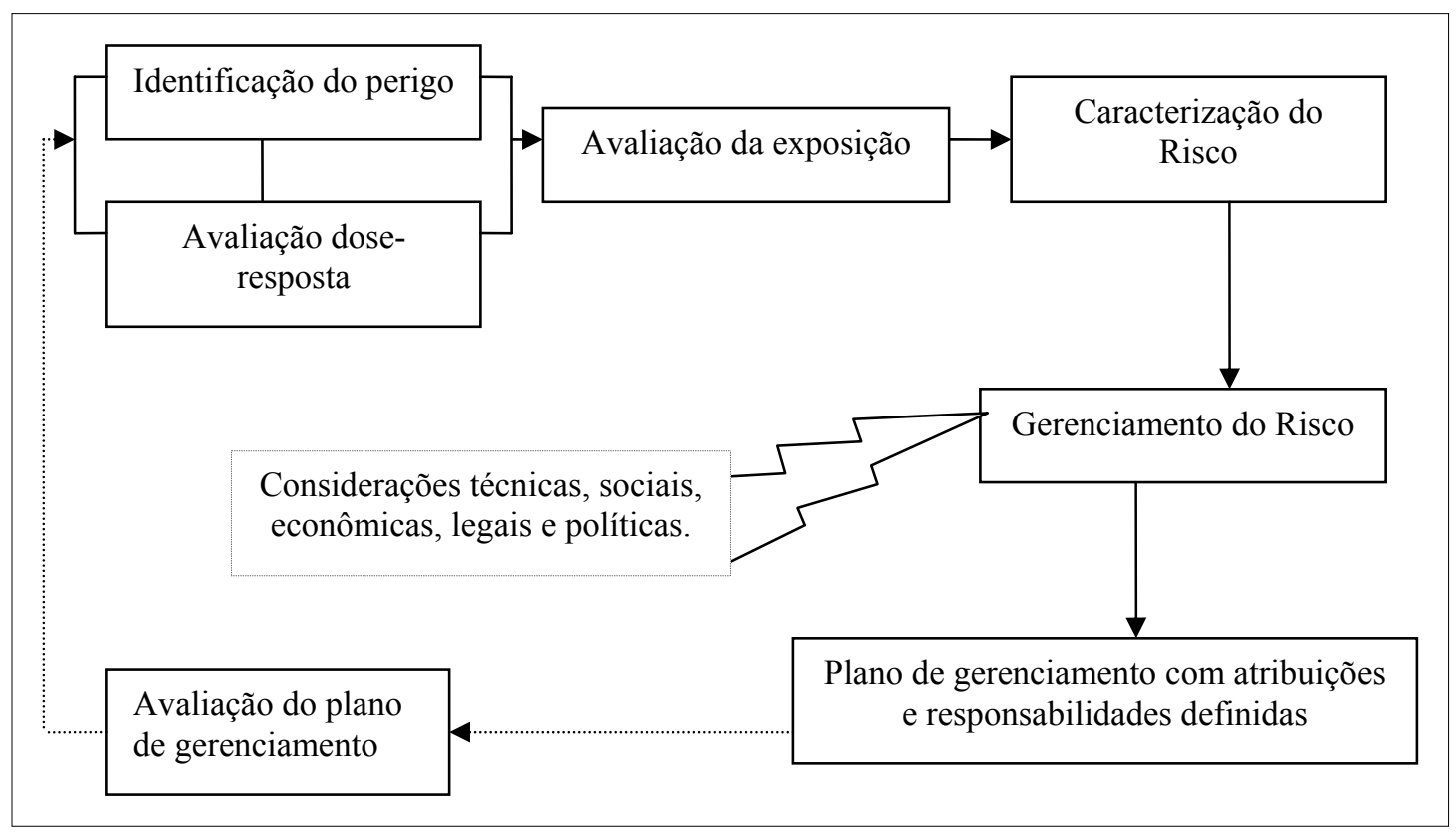

Fonte: Baseada em NRC (1983).

No que se relaciona ao conteúdo destas etapas, de modo resumido são:

(1) Identificação do perigo: consiste em determinar se um produto químico particular está ligado ou não a um determinado efeito adverso à saúde (NRC, 1983), e envolve a caracterização da natureza e da força da evidência causal. 
Segundo RODRICKS (1992), a identificação do perigo de uma substância química demanda o conhecimento sobre sua inflamabilidade, explosividade, radioatividade e toxicidade. Para a avaliação do perigo, como etapa da avaliação de riscos, todos os estudos epidemiológicos, dados experimentais de toxicidade e ecotoxicidade devem ser avaliados criticamente visando identificar a ação tóxica que a substância de interesse pode causar, e como os seres humanos e o meio ambiente estariam vulneráveis a estes efeitos, e sob quais condições.

(2) Avaliação da dose-resposta: Nesta etapa determina-se a relação entre a magnitude da exposição e a probabilidade de ocorrência do efeito adverso em análise (NRC, 1983).

A avaliação da dose-resposta baseia-se na elaboração de curvas dose-resposta, que descrevem a relação que existe entre o nível de exposição a uma substância (dose) e o seu efeito no organismo exposto (GARCIA, 2000). Dependendo da substância, a curva pode apresentar ou não um nível de exposição (limiar) abaixo do qual não são observadas respostas ou efeitos adversos, denominado NOAEL [No observed adverse effect level]. Estas substâncias são classificadas como não carcinogênicas. Por outro lado, as substâncias carcinogênicas podem apresentar os dois tipos de efeitos, os sistêmicos e os carcinogênicos. Os efeitos carcinogênicos não possuem limiar, ou seja, qualquer exposição está associada a um risco, mas os efeitos sistêmicos têm limiar.

Para as substâncias não carcinogênicas, o NOAEL ou, caso este não esteja disponível, o LOAEL [lowest observed adverse effect level], que é a menor dose ou concentração de uma substância onde é observado um aumento significativo na freqüência ou severidade dos efeitos adversos na população exposta em relação ao controle, são utilizados por várias agências governamentais para propor os valores que correspondem aos níveis de exposição (NE) para substâncias não carcinogênicas. Onde: $\mathrm{NE}=$ nível de exposição $=$ NOAEL $($ ou LOAEL $) \div$ Fator de incerteza e/ou de segurança (GARCIA, 2000).

No caso das substâncias carcinogênicas, o dado toxicológico empregado pela USEPA para estimar o risco de câncer, é o fator de carcinogenicidade - SF (slope factor), que pode ser definido como o limite superior da probabilidade de um 
indivíduo desenvolver câncer por unidade de exposição, durante o tempo de vida, para uma determinada substância. A USEPA utiliza uma classificação decrescente quanto à evidência da substância causar câncer, que varia de substâncias do Grupo A até Grupo E. O fator de carcinogenicidade só é calculado para as substâncias do Grupo A e B (divididas em subgrupos B1 e B2). As substâncias do grupo E são classificadas como as que possuem evidências de efeitos não carcinogênicos ao homem.

A Agência Internacional de Pesquisa sobre o Câncer [International Agency for Research on Cancer], IARC (sigla em inglês), classifica as substâncias, de acordo com o risco carcinogênico para humanos, em 4 grupos. Grupo 1 inclui os agentes que são carcinogênicos; Grupo 2 (dividido em 2 classificações), inclui agentes com probabilidade de serem carcinogênicos e o Grupo 3 inclui os agentes não carcinogênicos (IARC, 2004)

(3) Avaliação da exposição: é a etapa determinação da exposição humana (NRC, 1983), ou seja, é a análise da magnitude e da duração da exposição ao agente, bem como das diferentes formas de exposição dos organismos.

A condição da exposição (dose e duração) interfere na natureza e na severidade dos efeitos tóxicos produzidos. Além disso, a exposição depende de fatores como forma de contato, vias de introdução do agente no organismo e a sua toxicocinética.

A União Européia define avaliação da exposição como a quantificação de um agente ambiental que atinge um indivíduo (dose exterior), ou é absorvido por ele (dose interior, absorvida).

A toxicidade de um agente químico pode ser definida, de acordo com a duração da exposição, como: exposição aguda, exposição crônica, ou exposição sub-crônica. A exposição aguda envolve uma única dose; a exposição crônica geralmente faz referência a uma exposição ocorrida durante toda a vida, ou quase toda a vida; e a exposição sub-crônica, apesar de não ser bem definida, refere-se às exposições que ocorrem repetidamente ao longo da vida (RODRICKS, 1992).

A análise da exposição de populações expostas a "xenobióticos" envolve o conhecimento das fontes de emissão dos contaminantes, das transformações, transporte e acúmulo no ambiente, das vias de ingresso no organismo, da 
biodisponibilidade da dose biologicamente efetiva, entre outros (SILVA e FAY, 2003).

(4) Caracterização do risco: é a etapa de descrição da natureza e magnitude dos danos à saúde humana, incluindo considerações sobre as incertezas (NRC, 1983).

A caracterização do risco envolve a combinação das etapas anteriores, e é o último passo na avaliação de risco e a base para a decisão do regulador, uma vez que é o ponto de partida para as considerações a serem feitas sobre o gerenciamento do risco (NRC, 1994).

Um dos principais problemas desta etapa está relacionado à qualidade dos dados utilizados e a deficiência de informações completas ou confiáveis, fundamentais para caracterizar a natureza e extensão dos riscos. Estas fontes de incertezas envolvem a variabilidade nos valores dos parâmetros ambientais e sociais, erros de medida e a falta de informação adequada (HACON, 2003).

Diferentes considerações podem ser feitas no processo de avaliação de risco, devido às incertezas científicas nele embutidas. $O$ processo de avaliação, além de depender do contexto social e econômico, deve ser realizado de acordo com o contexto das políticas especificas do país executor (ANDERSON e HILAIRE, 2004).

(5) Gerenciamento do risco: segundo a proposta do NRC (1983), este é o último passo da avaliação de riscos. É a etapa da discussão das alternativas técnicas e políticas e da seleção das ações regulatórias mais apropriadas. Trata-se do processo de formulação e implantação de medidas e procedimentos com a finalidade prevenir, reduzir e controlar os riscos presentes em uma atividade, integrando o resultado da etapa de caracterização de risco com considerações técnicas, sociais, econômicas e políticas, para chegar a uma decisão (NRC, 1983).

Nos Estados Unidos da América, o gerenciamento de risco é conceituado como o processo de identificação, seleção e implementação de ações para reduzir o risco para a saúde humana e o meio ambiente (PRESIDENTIAL ..., 1997).

O programa de gerenciamento de riscos deve ter como prerrogativa especificar de maneira clara e objetiva as atribuições e responsabilidades dos envolvidos, e deve ser 
continuamente reavaliado com vistas ao aprimoramento das medidas propostas para a redução do risco.

Estas têm sido as etapas de uma avaliação de riscos, que foram originalmente aplicadas apenas para a avaliação de riscos à saúde humana. Posteriormente esta proposta foi adotada como referência para a avaliação ambiental, valendo-se das similaridades existentes entre os dois enfoques (BODAR et al. 2002), e vem sendo amplamente utilizada no processo de gerenciamento ambiental.

Na essência não existe distinção entre avaliação de risco à saúde humana e avaliação de risco ambiental, mas a abordagem tradicional distingue estas duas etapas.

A avaliação de riscos à saúde humana considera os efeitos tóxicos potenciais, para todas as vias de exposição (oral, dérmica e inalatória) dos diversos grupos populacionais, por exemplo, trabalhadores, consumidores e população em geral. Os diversos grupos expostos devem ser examinados quanto aos vários efeitos possíveis toxicidade aguda, irritação, corrosão, sensibilização, mutagenicidade, carcinogenicidade e toxicidade reprodutiva (HACON, 2003).

Além da exposição a que o homem está submetido, a avaliação de riscos à saúde humana, inclui a avaliação da toxicidade de uma substância química no organismo humano, cuja complexidade pode ser percebida na Figura 5, elaborada a partir do esquema proposto por RODRICKS (1992).

Por sua vez, a avaliação de risco ambiental é realizada por meio da comparação entre as estimativas de valores de concentração ambiental nos compartimentos ambientais (ar, solo, sedimento, água e na biota), denominado na União Européia como "Predicted Environmental Concentration - PEC", calculado com base no pior cenário, e as estimativas de valores de concentração que não causam efeito, denominados "Predicted No Effect Concentration - PNEC". Quando o valor do PEC excede o PNEC, deve ser considerada a existência de risco ambiental, diretamente proporcional à razão PEC/PNEC (UNEP/IPCS, 1999).

A avaliação ambiental demanda o levantamento de todas as informações possíveis sobre o contaminante, no que se refere à suas propriedades físico-químicas e toxicológicas, e a avaliação em todos os compartimentos ambientais (ar, água, solo, sedimento) e de elementos da biota representativa, pertencentes aos diferentes níveis 
tróficos da cadeia alimentar - como microcrustáceos, peixes, plantas, organismos do solo. Neste sentido são importantes tanto os dados oriundos de programas de monitoramento ambiental, como os dados obtidos de modelos matemáticos, que prevêem processos ambientais diversos, como adsorção, degradação, bioacumulação, entre outros.

FIGURA 5 Etapas da exposição, absorção, distribuição, depósito e excreção de uma substância química no organismo humano.

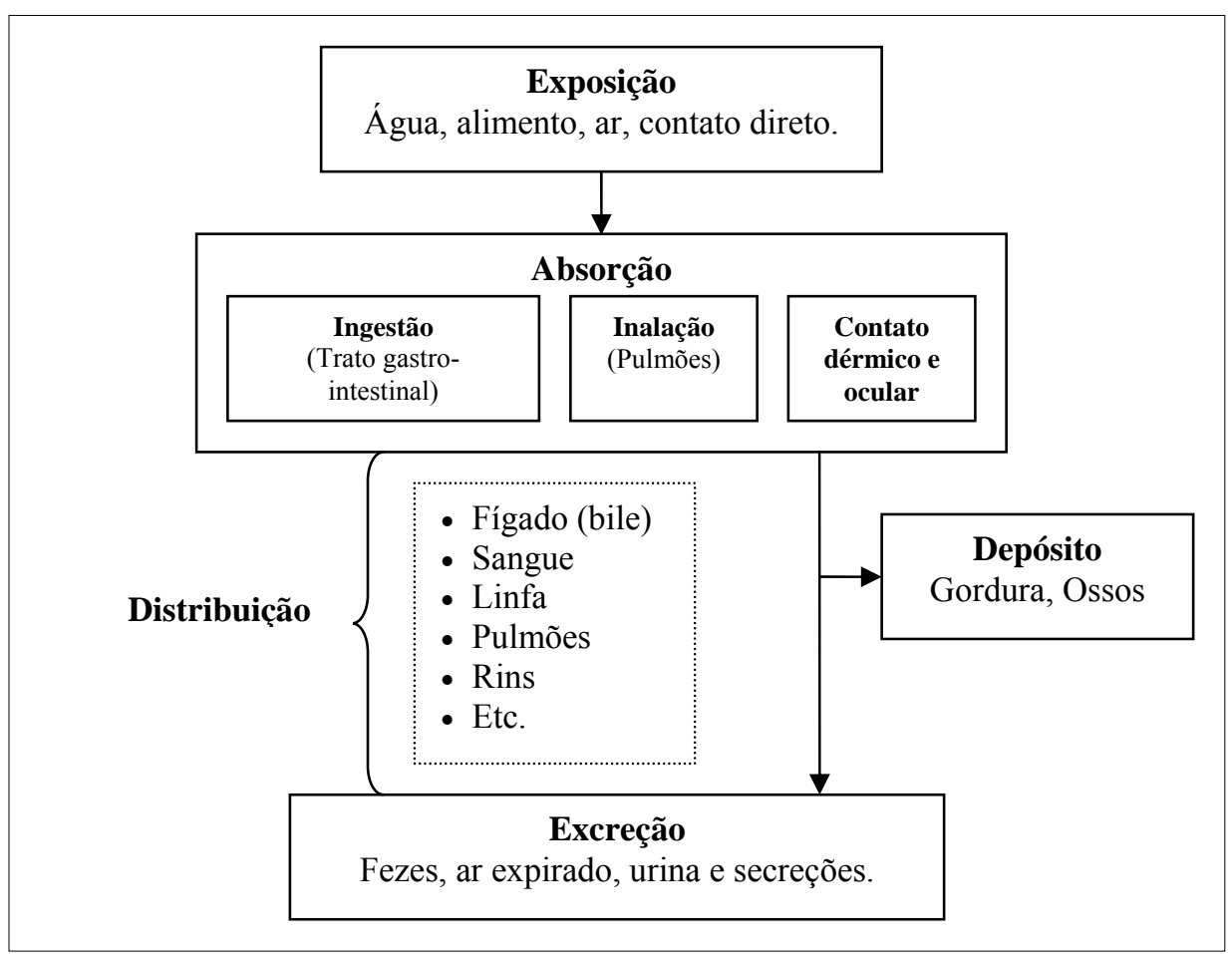

Fonte: Adaptado de RODRICKS (1992).

De forma geral, a avaliação de riscos à saúde humana tem sido tratada separadamente da avaliação de riscos ambiental. A causa deste tratamento demanda uma longa discussão, tanto de cunho político quanto técnico, principalmente com relação à imprecisão no emprego dos termos "risco à saúde" e "risco ambiental".

O desenvolvimento tecnológico e a globalização trouxeram novas e complexas situações de risco fazendo com que, nos últimos dez anos, o enfoque da avaliação de riscos tenha se tornado cada vez mais amplo. A consciência de que o homem está sob impacto direto das mudanças ambientais, e que a degradação ambiental influi 
diretamente sobre a saúde humana e o bem estar social, reforçou o enfoque de saúde pública que combina conceitos de saúde com fatores ambientais (WHO, 1990, apud BRILHANTE, 1999).

Sempre que se fala em risco, deve ser considerado pra quem este risco vai existir. $\mathrm{Na}$ essência, a avaliação de riscos à saúde humana e a avaliação de riscos ambiental tem como meta final a proteção do homem, o qual é tomado como o mais sensível.

A similaridade das avaliações ambientais e de saúde humana reside no fato da definição dos valores de concentrações ambientais aceitáveis, como PEC/PNEC, por exemplo, ocorrerem em função dos possíveis efeitos à saúde humana. Estes valores são, portanto, em última análise, referenciais ambientais para facilitar o processo de avaliação.

As avaliações ambiental e à saúde humana abordam pontos em comum, no que se refere à fontes e emissões, rotas/caminhos de distribuição e cenários de exposição (VERMEIRE et al., 2003). Desta forma, a separação ocorre devido às dificuldades técnicas e políticas para o tratamento do assunto de forma harmônica, incluindo a tentativa de delimitar áreas de atuação nas esferas administrativas.

Tecnicamente, a visão holística do problema só foi alcançada com a experiência adquirida na aplicação das metodologias e na observação de correlações entre os eventos.

No âmbito político, as questões ambientais e de saúde sempre foram tratadas em instituições independentes, cujas competências foram definidas a partir de critérios essencialmente burocráticos.

Hoje se sabe que a avaliação dos riscos é uma atividade que deve ser realizada de forma coordenada, com a integração da banco de dados de informações, o que leva à obtenção de resultados mais coerentes e reais.

Nos últimos anos também tem sido desenvolvida uma metodologia para avaliação dos efeitos adversos para outros elementos de um ecossistema (AMARAL e SILVA, 2003), denominada avaliação de risco ecológico.

A avaliação de risco ecológico pode ser definida como o processo que avalia a probabilidade dos efeitos adversos ocorrerem ou estarem ocorrendo em um 
ecossistema, como resultado da exposição a um ou mais estressores ${ }^{11}$ (USEPA, 1998), considerando as complexas condições da exposição e seus efeitos sobre o ecossistema.

Segundo a UNEP/IPCS (1999), a avaliação de risco ecológico deve ser iniciada com a formulação do problema, seguida pelas etapas de (1) discussão entre o avaliador e o gerenciador de risco; (2) definição das características do estressor (biológico, físico ou químico); (3) identificação do(s) ecossistema(s) sob risco; (4) identificação dos efeitos ecológicos; (5) seleção dos "endpoints" (pontos de referência, pontos de corte); (6) modelagem do ecossistema sob risco para obtenção de informações; (7) aplicação de dados ao modelo e verificação da exatidão do modelo; (8) obtenção de dados adicionais; (9) estabelecimento e manutenção do programa de monitoramento.

Tendo em vista estas etapas, percebe-se que esta avaliação demanda o conhecimento dos componentes ecológicos do sistema, e suas inter-relações com os agentes estressores, devendo ser selecionados tanto os organismos que representem os alvos dos mecanismos de toxicidade, como os caminhos de exposição referentes aos potenciais agentes estressores. Além disso, devem ser mensuradas as respostas biológicas qualitativas e quantitativas em relação aos agentes estressores (HACON, 2003);

Conhecer um sistema ecológico e suas inter-relações é uma tarefa complexa e, escolher qual componente, ou quais componentes são os mais importantes é uma questão que envolve prioridades e julgamentos de valor que, obviamente, influenciarão diretamente no resultado da avaliação (NARDOCCI, 1999).

As principais considerações sobre o procedimento de avaliação de risco ecológico dizem respeito ao excesso de incertezas do processo de avaliação, principalmente àquelas decorrentes da necessidade do profundo conhecimento sobre a dinâmica do ecossistema em análise.

A complexidade desta avaliação também deriva do fato de que são tarefas do avaliador e do gerenciador de riscos ecológico conciliar as metas da sociedade com a realidade científica. Entretanto, se por um lado a ciência impõe limitações, por outro, as metas da sociedade podem variar desde a proteção de espécies em extinção, até a

11 Substância química, circunstância ou campo energético que causa impactos positivos ou negativos. 
proteção de um pescado, ou mesmo, preservação da estrutura e função de um ecossistema.

Uma das formas de melhorar a credibilidade desta avaliação seria a limitação de suas fronteiras, mas isto reduziria a amplitude da abordagem e poderia levar a um resultado não significativo para a tomada de decisão (NARDOCCI, 1999).

Deve-se destacar que os resultados da avaliação de riscos à saúde humana e da avaliação de risco ecológico não podem ser comparados de forma direta nem combinados, pois são realizadas separadamente, e se baseiam em diferentes suposições e procedimentos. A integração das avaliações levaria a considerações múltiplas sobre rotas de exposição, misturas de substâncias, endpoints, receptores, dentre outras, podendo inviabilizar a análise devido ao excesso de considerações (SUTER et al. 2003).

Estes são alguns dos motivos que fazem com que a metodologia de avaliação de risco ecológico ainda esteja em processo de discussão e pesquisa, e o enfoque normalmente utilizado para fins regulatórios restrinja-se à avaliação dos riscos à saúde humana.

A despeito da complexidade e dos desafios para o desenvolvimento e uso da avaliação de riscos, ANDERSON e HILAIRE (2004) ressaltam que esta ferramenta é indispensável para garantir que o processo de tomada de decisão, relacionado à saúde humana seja realizado a partir de referenciais definidos.

Julgar os resultados de uma avaliação de riscos é um processo complexo, uma vez que os "pré-conceitos" dos gestores influenciam o resultado final. Por isso, o NRC (1983) recomenda que o melhor meio de garantir a integridade do processo de avaliação de risco é a elaboração de orientações claras sobre os princípios que os avaliadores devem seguir para interpretar e julgar os dados científicos.

Neste contexto, a discussão sobre o uso de critérios determinísticos para avaliar os riscos, que resultam em valores pontuais e objetivos; ou critérios probabilísticos, que resultam em valores baseados na freqüência de eventos ocorridos, bem como sobre a interpretação dos resultados, tem sido foco de vários estudos. 
As técnicas determinísticas de avaliação são aquelas que geram um quociente entre a concentração de exposição e o respectivo efeito, resultando em um índice bruto de magnitude e efeito, que pode ser utilizado para comparações, o que tem sido aceito tanto pelo governo (reguladores) quanto pela indústria, para avaliar substâncias químicas. Como se opta por considerar o "pior caso" realiza-se, conseqüentemente, estimativas conservativas, que se configuram no caminho as mais "seguro", tendo em vista a grande incerteza associada a todos os aspectos da avaliação de riscos.

Em um estudo de avaliação da exposição do consumidor, utilizando-se critérios determinísticos FERRIER et al. (2002) afirmaram que o modelo determinístico produz estimativas apenas para os maiores consumidores, o que faz com que os gestores sintam-se tranqüilos para tomar decisões, já que estariam utilizando altas doses de referência. Este conservacionismo, entretanto, pode levar a restrições desnecessárias decorrentes da super estimativa da ingestão.

Por outro lado, a avaliação probabilística de riscos é aquela que utiliza distribuições de probabilidade para caracterizar variabilidade e/ou incertezas nas estimativas de risco, onde uma ou mais variáveis são definidas matematicamente por meio da distribuição de probabilidades (FERRIER et al. 2002). Nesta metodologia é necessária uma seleção repetida de valores, de complexos modelos matemáticos e de sofisticados programas de computador.

Enquanto a metodologia determinística produz estimativas úteis e aceitáveis, apesar de serem conservativas e geralmente superarem o valor real (FERRIER et al. 2002), os métodos probabilísticos expressam a variabilidade e a incerteza. Entendendo-se por variabilidade a heterogeneidade ou diversidade, e por incerteza o que decorre da falta de conhecimento, ou da imprecisão dos parâmetros.

A utilidade das técnicas probabilísticas na avaliação de riscos de agrotóxicos é objeto de discussão, principalmente com relação à interpretação dos resultados e à falta de dados e referenciais para tomada de decisão (FERRIER et al. 2002).

A decisão sobre o uso do método probabilístico depende de vários fatores dentre eles, do tipo de agrotóxico, do modo de uso, da complexidade dos problemas devido ao seu comportamento e da qualidade dos dados existentes. 
Estes autores afirmam que a utilização de métodos probabilísticos na avaliação da exposição de consumidores a agrotóxicos é mais bem aceita nos Estados Unidos, do que na União Européia. Isto, provavelmente, pelo fato do enfoque norte americano ser voltado para a responsabilidade compartilhada entre o governo e o produtor, fazendo com que este último seja responsabilizado pelo produto em qualquer etapa do ciclo de vida, ao passo que, na CEE, a abordagem é mais preventiva, sendo utilizados mecanismos mais restritivos no inicio do processo, ou seja, na aprovação do produto.

Desta forma a avaliação probabilística é vista com certo cuidado pelas autoridades públicas responsáveis pela regulação que visa proteger a saúde e ao meio ambiente.

Os avaliadores e gerenciadores de riscos reconhecem que, apesar dos métodos determinísticos darem certa segurança, eles contêm um grau de conservacionismo desconhecido e tendem a obscurecer as incertezas e a variabilidade.

Entretanto a crescente discussão e geração de documentos de comparação entre estimativas determinísticas e previsões probabilísticas, tanto no âmbito acadêmico como nos comitês de especialistas, além do desenvolvimento e utilização de ferramentas e métodos probabilísticos, dentre outros, devem contribuir para que a avaliação de riscos de substâncias químicas se torne cada vez mais transparente e seus resultados mais aceitáveis e úteis.

\subsection{Gerenciamento de Substâncias Químicas}

Segundo o NRC (1983), existe uma diferença conceitual entre a avaliação e o gerenciamento dos riscos. A finalidade da avaliação de riscos é descrever, na medida do possível, as conseqüências à saúde decorrentes da exposição a substâncias perigosas utilizando a melhor técnica científica disponível, associada à suposições consistentes com a ciência. O gerenciamento, por sua vez, tem como finalidade avaliar a relação entre os efeitos à saúde e as ações reguladoras específicas.

Conforme apresentado na Figura 4, o programa de gerenciamento é a etapa de finalização da avaliação de riscos. Segundo ANDERSON e HILAIRE (2004), o NRC recomenda que a avaliação de riscos tenha sua integridade preservada da influência dos reguladores por ser a base científica para o gerenciamento. 
Desta forma, durante a elaboração do programa de gerenciamento são considerados os aspectos legais, políticos, econômicos e sociais, mas as informações utilizadas na caracterização do risco, por serem fruto de um trabalho técnico-científico complexo, tornam-se a base principal para a decisão sobre o gerenciamento.

Deve ser considerado, entretanto, que, via de regra, os dados científicos que subsidiam a caracterização do risco são obtidos por meio de testes de laboratórios, que consideram uma única substância e uma única fonte de exposição por vez. Estes dados geralmente sofrem uma série de aproximações que podem culminar em considerações muito generalizadas ou muito específicas.

Tradicionalmente, na avaliação de riscos, os produtos, os meios e os riscos são abordados de forma individualizada. A atenção é voltada para o refinamento de estimativas e suposições matemáticas de riscos devidos às exposições às substâncias individuais, baseadas em estudos realizados separadamente nos compartimentos ambientais (ar, água, solo), e em estudos de toxicidade realizados em altas doses, em animais de laboratório (PRESIDENTIAL ..., 1997).

Esta abordagem individualizada leva a estratégias de gerenciamento centradas nos mecanismos regulatórios do tipo "comando e controle", ou seja, na fixação de normas e padrões e no controle do atendimento destes parâmetros, por meio de procedimentos como o licenciamento, registro e a fiscalização.

O uso de mecanismos de comando e controle, apesar de ter o seu valor, tem sido criticado pelo fato de não estimular a introdução de inovações tecnológicas de prevenção e de representar um peso significativo para o Estado, uma vez que a sua eficiência depende de um aparato institucional de alto custo (BARBIERI, 1997).

O gerenciamento individual de substâncias químicas, baseado no mecanismo de “comando e controle" é extremamente importante para a redução dos riscos à saúde humana e ao meio ambiente, mas, quando é considerada a complexidade da sociedade contemporânea, onde novas e variadas fontes de risco são continuamente introduzidas, este mecanismo deve ser questionado.

Em 1990, o Congresso dos Estados Unidos instituiu a "Comissão sobre Avaliação e Gerenciamento de Riscos" com a finalidade de avaliar as implicações políticas e o uso da avaliação e gerenciamento de riscos nos programas de regulamentação de leis 
para prevenção de câncer e de outros efeitos crônicos à saúde humana, oriundos da exposição às substâncias perigosas.

Esta Comissão publicou, em 1997, um relatório sobre o gerenciamento de riscos em saúde ambiental, propondo uma modificação na visão tradicional do gerenciamento de riscos (PRESIDENTIAL...., 1997). O ponto chave da proposta é a ampliação da noção de gerenciamento que, ao invés de ser uma etapa da avaliação de riscos, passa ser a denominação de todo o processo de tomada de decisão. Neste contexto, a análise de risco passa a ser uma etapa do sistema de gerenciamento, o qual dá a base científica para a tomada de decisão.

De forma sucinta, a proposta da Comissão consiste em um sistema cíclico integrado de seis estágios: (1) definição e contextualização do problema; (2) análise dos riscos associados com o problema contextualizado; (3) exame das opções relacionadas ao risco; (4) tomada de decisão sobre quais opções implementar; (5) implementação, e; (6) avaliação das ações implementadas. Neste ciclo, a participação de todos os atores é o elemento central.

Este sistema integrado de gerenciamento baseia-se em três pontos chave: (1) contexto mais amplo, o que significa avaliar os problemas de saúde e meio ambiente a partir de um ponto de vista mais amplo e mais real, visando tornar claro o impacto que uma ação específica de gerenciamento pode ter sobre a saúde pública ou o meio ambiente e, assim, melhor direcionar as ações e os recursos; 2) participação dos atores, ponto fundamental para o sucesso das ações de gerenciamento; e, (3) Interação entre os estágios, permitindo a reavaliação durante o gerenciamento, uma vez que novas informações podem implicar, por exemplo, na proposição de ações mais efetivas e de menor custo.

O relatório ressalta que esta visão ampla do gerenciamento é adequada para as decisões envolvendo riscos relacionados ao controle de poluição, proteção à saúde e recuperação ambiental, em nível local (por exemplo, instalação de um incinerador), ou nacional (por exemplo, o desenvolvimento de programas de controle de emissão veicular), mas não é adequada para situações de risco que exigem ações emergenciais. Outra vantagem do processo proposto é a não restrição da tomada de decisão a um processo simplista de análise de resultados, do tipo comando e controle. 
A definição do contexto do problema é considerada a principal etapa do processo de gerenciamento, quando são identificadas as características do problema e a dimensão do contexto em que ocorre (fontes causadoras, meios afetados). Após esta etapa as metas do gerenciamento e os gerenciadores (parceiros, atores) envolvidos são identificados e, finalmente, é estabelecido o processo de integração entre os envolvidos para realizar a avaliação dos riscos.

Nesta etapa o gerenciador do risco, procurando visualizar o problema no contexto real, deve considerar os possíveis múltiplos contaminantes, as suas múltiplas fontes e as múltiplas possibilidades de exposição.

As metas do gerenciamento, propostas nesta etapa, podem variar entre opções como a redução ou eliminação do risco de exposição a uma substância perigosa, ou a proteção de populações.

A avaliação de riscos é realizada após a contextualização do problema, por meio de considerações sobre os perigos, a exposição e a relação exposição-resposta, resultando na caracterização do risco, sendo a base científica para a decisão sobre o gerenciamento.

Apesar de ter as mesmas etapas da avaliação de riscos proposta pelo NRC (Figura 4), a natureza da avaliação de riscos nesta proposta tem a sua extensão e foco balizado pelas metas de gerenciamento, definidas na etapa de contextualização.

Para compreender um sistema de gerenciamento baseado em múltiplos meios e múltiplas fontes, o gerenciador deve valer-se da avaliação de risco que utiliza este referencial múltiplo, sendo necessário que o paradigma da avaliação de risco seja expandido. Segundo a Comissão (PRESIDENTIAL.... 1997), a USEPA utiliza esta visão quando considera outras fontes de exposição e a outros agrotóxicos similares, durante o processo de "reregistro" de um agrotóxico.

A não consideração de múltiplas e acumulativas exposições é uma deficiência da metodologia de avaliação e gerenciamento de riscos, atualmente executada.

O relatório relata que a falta de dados continua a ser a maior barreira para o correto gerenciamento dos riscos, além disso, dificulta a implementação desta nova proposta o fato dos regulamentos ambientais os programas das agências ambientais e as 
discussões que ocorrem nos comitês do Congresso Norte Americano, focalizarem o gerenciamento de um poluente individual em um único meio.

Apesar das dificuldades, a proposta da Comissão representa a abordagem correta para o gerenciamento das substâncias químicas, uma vez que a relação saúde/ambiente envolve uma infinidade de abordagens interdisciplinares, e só compreendendo este cenário, com a correta contextualização do problema, será possível intervir eficazmente para a redução do risco.

Segundo NARDOCCI (1999), o gerenciamento deve ser considerado não apenas como um conjunto de regras e procedimentos que devem ser seguidos após a avaliação, mas sim como um conjunto de todas as atividades técnicas e legais, decisões e escolhas sociais, políticas e culturais, que se relacionam direta ou indiretamente com as questões de risco.

Neste sentido, um sistema de gerenciamento de riscos para substâncias químicas deve ser composto pelas etapas apresentadas na Figura 6.

FIGURA 6 Etapa de um sistema de gerenciamento de riscos para substâncias químicas.

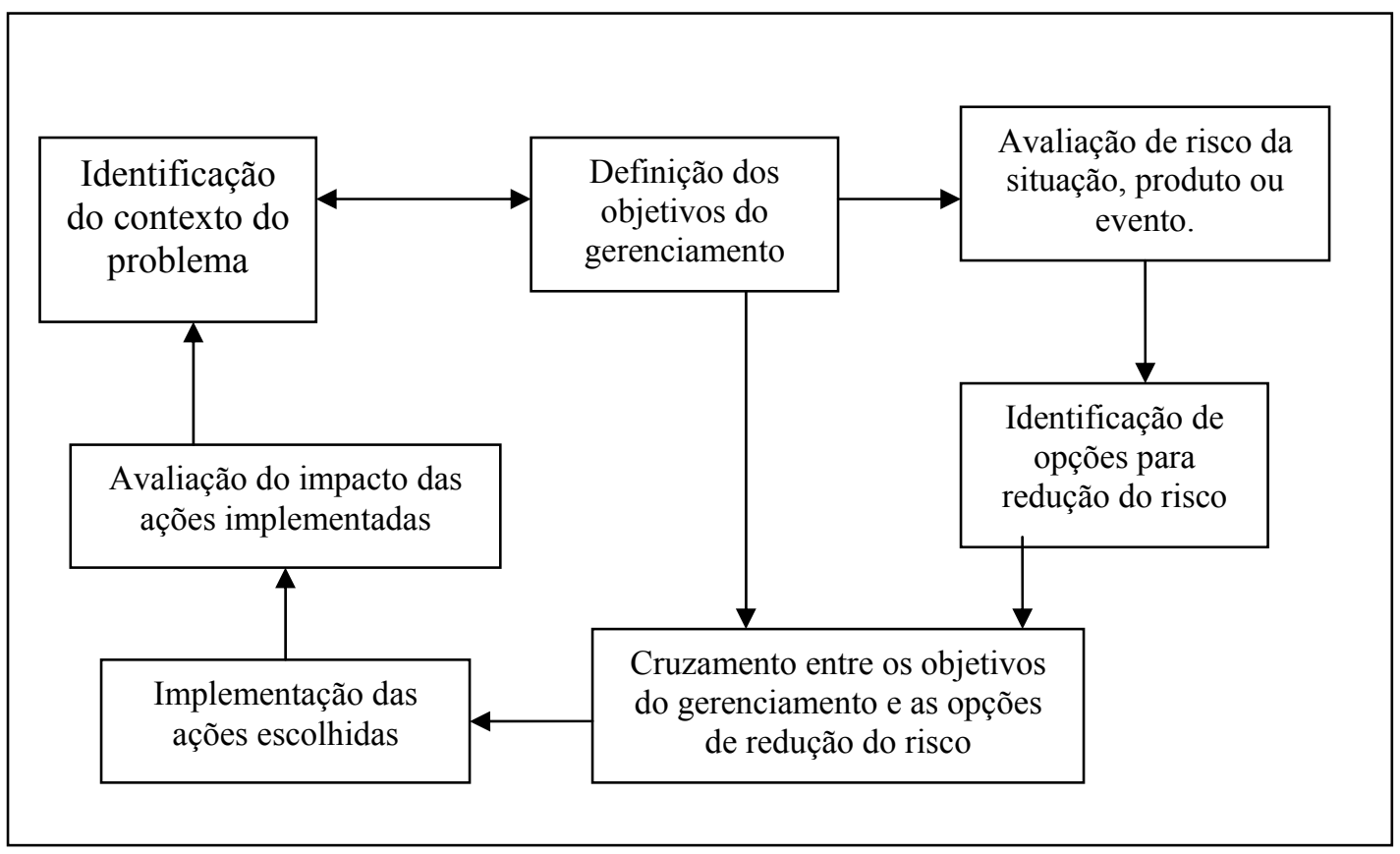

Fonte: Adaptado de PRESIDENTIAL ..., 1997 
Reconhecer o contexto em que o problema se encontra, envolve identificar as forças orientadoras que o levaram a ser considerado em um programa de gerenciamento, ou seja, os pontos chave que o tornaram prioritário. Tanto pode ser a ratificação de uma convenção internacional pelo país, como um programa nacional de controle de emissão veicular, ou mesmo um acidente de grandes repercussões. Desenvolver esta visão permite um fundamento crítico do processo de gerenciamento e cria uma base concreta para o processo, auxiliando na identificação de possíveis parceiros para a ação.

Os objetivos (metas) do gerenciamento serão naturalmente encontrados no processo de identificação do contexto e devem ser confrontados com as opções necessárias para a redução do risco, identificadas após o processo de avaliação do risco. Deste confronto resultam as alternativas mais factíveis para o correto gerenciamento da situação, substâncias ou evento.

O impacto das ações deve estar sob constante avaliação, com vistas não apenas ao atendimento dos objetivos previamente estabelecidos, como também, de novas demandas identificadas no processo de implementação. Por exemplo, no caso das substâncias químicas, ao se definir como meta a eliminação das substâncias carcinogênicas é possível criar mecanismos prévios para que a introdução de novas substâncias atenda a critérios rigorosos para isso, o que é mais efetivo do ponto de vista de gerenciamento.

A disponibilidade da informação, entretanto, também nesta abordagem, é a questão prioritária para o gerenciamento das substâncias químicas. Isto ocorre porque, em última análise, é o acesso à informação gera a necessidade de ações para redução de risco.

\subsection{Gerenciamento de Agrotóxicos}

A existência de um processo de análise das características de um agrotóxico, para fins de aprovação ou registro pelo governo federal, é uma regra em praticamente todos os países, diferindo apenas quanto ao grau de profundidade com que esta análise é realizada. 
Alguns países, geralmente os mais desenvolvidos, optam por desenvolver seu próprio sistema de análise, ou por adaptar sistemas de outros países. A maioria dos países menos desenvolvidos utiliza modelos de análise propostos por organizações intergovernamentais, como o Programa Internacional de Segurança Química - IPCS, da OMS.

Entretanto, independentemente do tipo de análise realizada, ela repercute diretamente no modelo de gerenciamento adotado pelo país. ZADOCKS e WAIBEL (2000), afirmam que, ao reconhecer os efeitos adversos dos agrotóxicos os governos passaram a agir com o reforço dos mecanismos regulatórios, principalmente no processo de registro de novos produtos. CALDAS e SOUZA (2000) ressaltam que os estudos conduzidos pelos governos, durante o processo de registro de agrotóxicos, influenciam diretamente no estabelecimento de limites máximos de resíduos permitidos em alimento, e nas restrições para uso em algumas culturas.

De forma geral, a introdução de um agrotóxico no mercado passa por um processo tradicional de análise de documentos, que inclui testes de eficácia agronômica e estudos científicos relacionados aos impactos à saúde humana e ao meio ambiente.

Os dados sobre a toxicidade do produto são obtidos mediante estudos com animais experimentais e procedimentos laboratoriais, geralmente padronizados pelos governos por meio de documentos orientadores (guidelines), que visam garantir a qualidade do resultado.

Em nível internacional, os principais guias (guidelines) utilizados nos testes com agrotóxicos são os publicados pela Organização Mundial de Saúde (OMS); pelo Programa Internacional de Segurança Química (IPCS/OMS), pela Agência Internacional de Pesquisa sobre Câncer - IARC/OMS (sigla em inglês); pelo Centro Pan Americano de Ecologia Humana e Saúde (ECO/OPS); pela Organização das Nações Unidas para Agricultura e Alimentação - FAO (sigla em inglês); pela Organização para Cooperação Econômica e Desenvolvimento da Comunidade Econômica Européia (OECD/CEE) e Agência de Proteção Ambiental dos Estados Unidos (USEPA) e pelo Registro Internacional de Substâncias Potencialmente Tóxicas do Programa das Nações Unidas para o Meio Ambiente - IRPTC/UNEP (sigla em inglês). No Brasil, além do reconhecimento destas metodologias 
internacionais, o IBAMA possui um manual com a metodologia para alguns testes com agrotóxicos (IBAMA, 1990).

A constatação dos efeitos adversos dos agrotóxicos para a saúde humana e o meio ambiente pode ser obtida utilizando-se várias metodologias que estão sujeitas à constantes modificações devido a complexidade do comportamento dos produtos. Entretanto, a maior dificuldade reside na obtenção ou geração de dados, estudos e informações sobre agrotóxicos.

Especificamente, com relação ao meio ambiente, MARGNI et al. (2002) ressaltam que muitos métodos têm sido propostos para estimar os impactos do uso de agrotóxicos, mas a maioria possui limitações devido à falta de uma definição clara sobre qual o impacto causado, além da negligência de importantes processos ambientais que podem ocorrer e da falta de informações toxicológicas.

Os protocolos de avaliação de riscos de agrotóxicos para fins de registro, têm como referencial a proposta do NRC (1983), utilizado para as substâncias químicas. A consideração particular que deve ser feita para os agrotóxicos, em relação às outras substâncias químicas de uso industrial, por exemplo, é a característica do uso, que os transformam em uma fonte difusa de contaminação.

De forma geral, a avaliação de risco de agrotóxicos é realizada em quatro etapas identificação do perigo, avaliação da dose-resposta, avaliação da exposição e caracterização do risco.

Como os aspectos relacionados à saúde humana e o meio ambiente são considerados separadamente, geralmente ocorre a diferenciação institucional para a realização da avaliação do risco à saúde humana e da avaliação dos riscos ambientais. Entretanto, dependendo da estrutura institucional do país para o gerenciamento dos agrotóxicos, ocorre a integração das avaliações na etapa de tomada de decisão.

Os caminhos, ou rotas, de exposição do homem aos agrotóxicos são mais complexos do que os da maioria das substâncias químicas.

O comportamento do agrotóxico no ambiente é bastante complexo. VERMIERE et al. (2003) apresentam um esquema de distribuição dos agrotóxicos nos compartimentos ambientais (ar, água e solo), a partir do seu uso. A Figura 7 
apresenta uma simplificação do esquema proposto pelos autores, modificado para incluir os potenciais organismos receptores, colocados entre parênteses, e os possíveis processos de transformação que ocorrem nos compartimentos.

FIGURA 7 Introdução dos agrotóxicos nos compartimentos ambientais, a partir do uso e possíveis processos de transformação que podem sofrer e possíveis receptores.

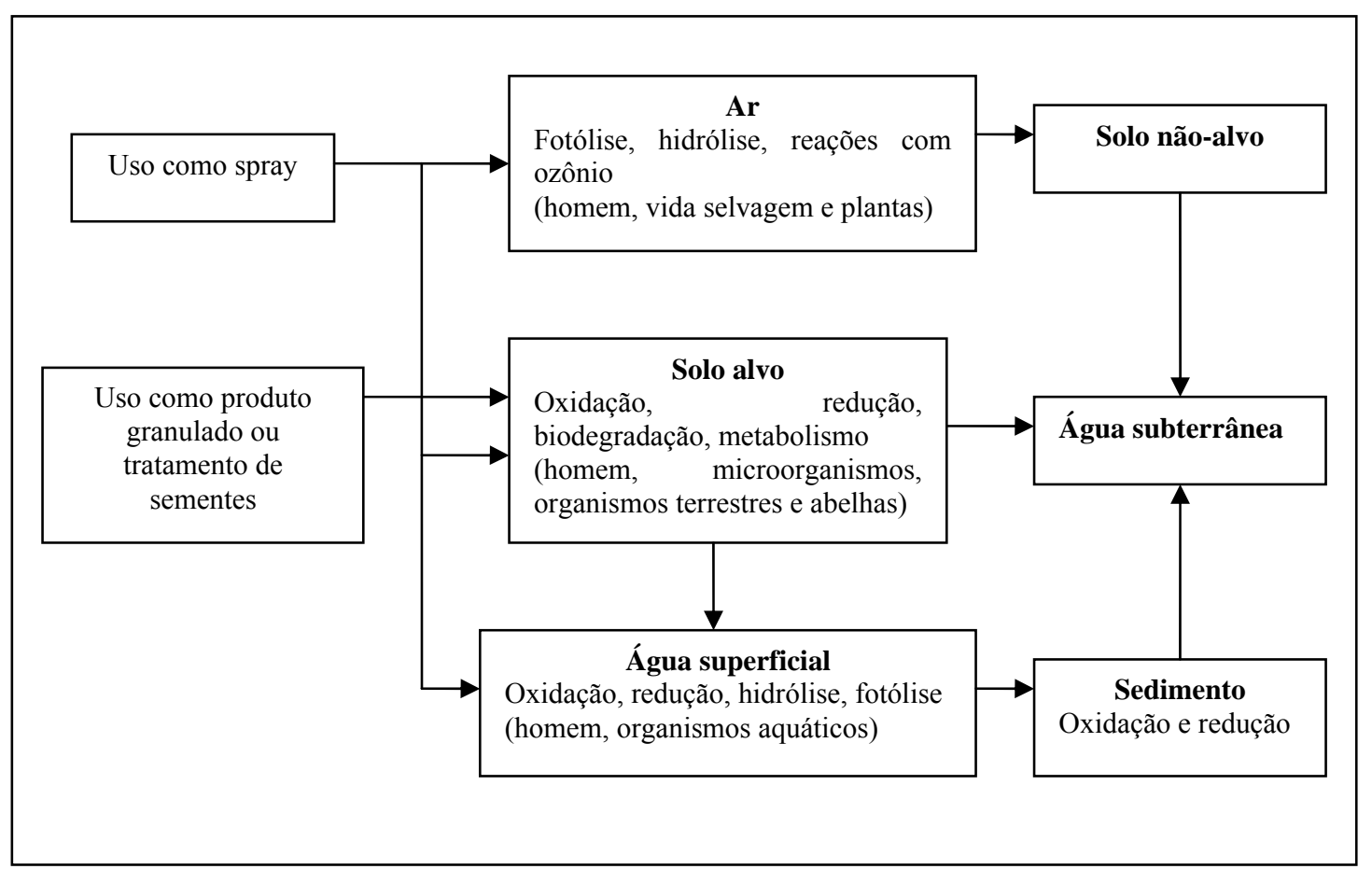

Fonte: Adaptado de VERMEIRE et al. (2003); UNEP/IPCS (1999).

A maior parte dos agrotóxicos utilizado, independente do modo de aplicação, acaba atingindo o solo e as águas, principalmente devido aos ventos e à água das chuvas, que promovem a deriva, a lavagem das folhas tratadas, a lixiviação e a erosão. Desta forma, qualquer que seja o caminho do agrotóxico no meio ambiente, invariavelmente o homem é seu potencial receptor.

A Figura 8 mostra uma representação esquemática dos possíveis caminhos de exposição, a partir de diferentes compartimentos ambientais. 
FIGURA 8 Representação esquemática das possíveis rotas de exposição humana aos agrotóxicos.

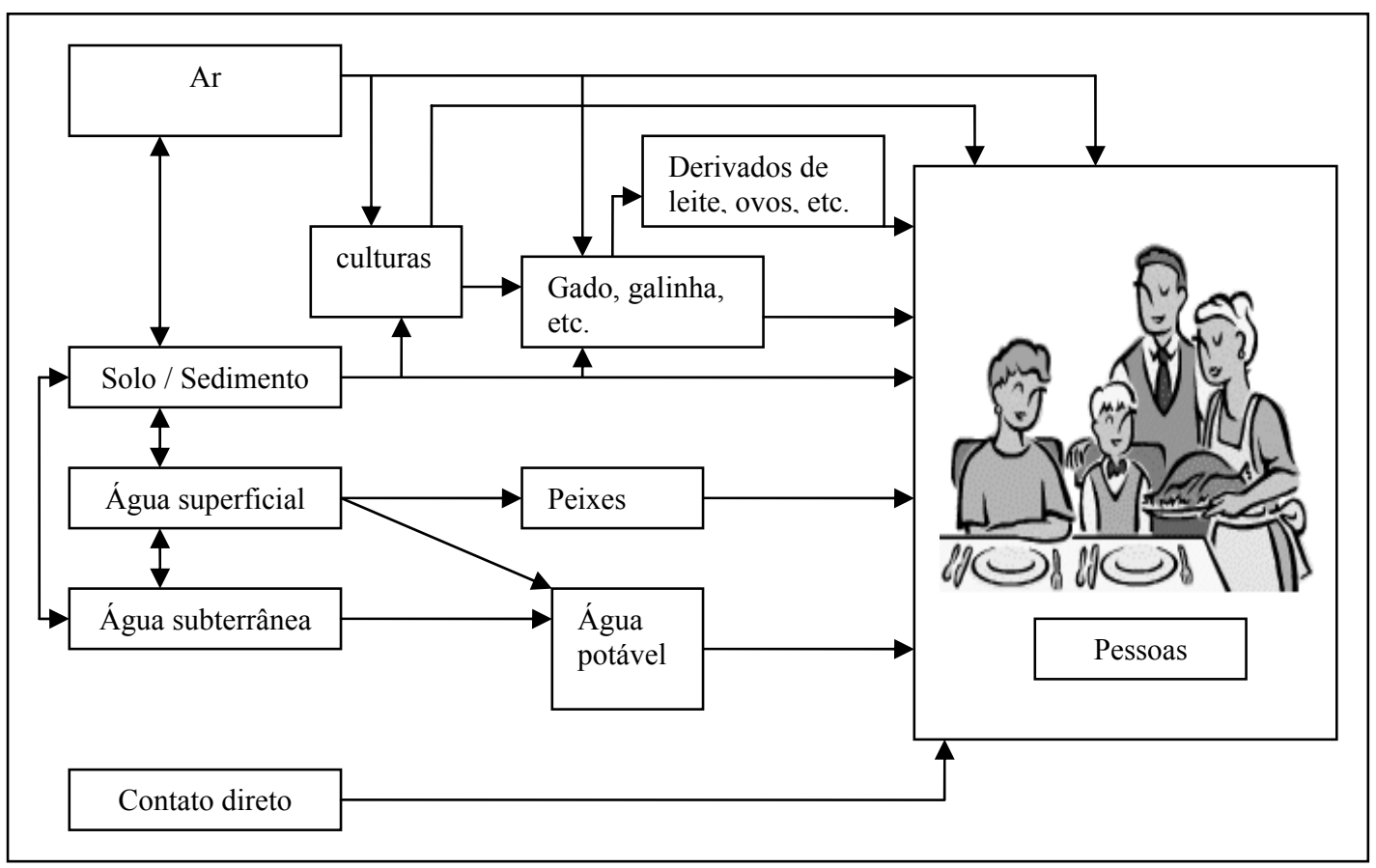

Fonte: VERMEIRE et al. (2003); UNEP/IPCS (1999), modificados.

Estima-se que, em 1985, ocorreram aproximadamente 1 milhão de casos intoxicações agudas não intencionais, sendo que 70\% ocorreram de forma direta, relacionada às atividades de trabalho (ocupacional) (ALVES FILHO, 2002).

A exposição indireta decorre do uso dos agrotóxicos, o que ZADOCK e WARBEL (2000) classificaram como fatores off site [longe do local de aplicação], e seriam, por exemplo, a poluição das águas e os efeitos de natureza intertemporal ou intergeracional. Tanto a exposição direta como a indireta tem repercussão sobre a expectativa de vida, o crescimento, a fisiologia, o comportamento e a reprodução (ALVES FILHO, 2002), e trazem graves conseqüências à saúde humana.

A complexidade da avaliação ambiental deve-se à necessidade de se considerar tanto o comportamento do agrotóxico como o dos agentes que atuam provocando seu deslocamento físico e sua transformação química e biológica.

Os caminhos (rotas) ambientais são específicos de cada substância e de cada local no qual a substância foi utilizada. A avaliação de todos os caminhos ambientais, em 
geral, é de difícil estimativa, principalmente porquê, para a maioria das substâncias químicas não é conhecido, com detalhes, o seu comportamento no meio ambiente.

Muitas substâncias sofrem processos físicos, ou químicos ou biológicos, os quais podem modificar as suas propriedades e influenciar no seu comportamento, inclusive com a formação de subprodutos com propriedades absolutamente distintas do produto inicial e cujos danos à saúde ou ao meio ambiente também são diferenciados. Estes subprodutos também devem ser considerados na avaliação de riscos.

Outro ponto de preocupação em relação aos agrotóxicos, diz respeito às embalagens que, quando abandonadas no campo, transformam-se em importantes fontes de contaminação.

Desta forma, é necessário o entendimento de todo o comportamento ambiental de um agrotóxico, incluindo a sua a especiação e transporte, para que o seu risco à saúde humana seja avaliado, bem como de todos os processos e mecanismos envolvidos.

A dificuldade de gerar informações que servirão de base para a avaliação de riscos dos agrotóxicos é comum a todos os países. Os governos sempre se deparam com desafios que podem variar desde a necessidade de gerar informações no campo toxicológico, ecotoxicológico, ocupacional e agronômico, até tomar decisões em situações que envolvem demasiada incerteza.

Podem ocorrer situações como, por exemplo, a identificação de um risco moderado para algumas populações, mas benefícios agrícolas importantes para a produção de alimentos no país. Se a conclusão for fruto de um processo baseado em risco o país pode optar pela permanência do produto no mercado e a imposição de restrições visando reduzir uma possível exposição (NRC, 1994), tendo que arcar com o impacto que esta decisão pode vir a causar na sociedade.

Ao elaborar o programa de gerenciamento de riscos de agrotóxicos na etapa de registro (pré-comercialização) os gestores atuam de forma preventiva, ou seja, lidam com a incerteza da ocorrência de problemas. Desta forma, a ação é de cunho preventivo e tem como referencial a probabilidade de ocorrência e magnitude dos efeitos obtidas do processo de avaliação de riscos. 
Assim, o gerenciamento não pode ser considerado apenas a etapa de elaboração das alternativas, mas em um sentido mais amplo, representa a "filosofia" do país para lidar com a questão, sendo a avaliação de riscos a base científica para as ações.

O gerenciamento de riscos de agrotóxicos envolve desde a simples rotulagem dos produtos, alertando para o perigo da manipulação e do transporte, até mecanismos complexos, como a comparação entre as propriedades de uma substância existente e uma nova, para fins de aprovação ou não da última.

A escolha sobre o modelo de gerenciamento de uma substância química deve ser cuidadosa, sob pena de comprometer o processo de gerenciamento com perda de credibilidade. PITTINGER et al. (2003), discutem vários mecanismos de avaliação de risco e afirmam que o modelo de gerenciamento deve ser baseado no grau de conhecimento que se tem da substância.

A avaliação comparativa das características dos produtos novos solicitantes de registro com produtos antigos já no comércio, e com igual finalidade de uso, deve ser cada vez mais utilizada como ferramenta preventiva de gerenciamento. Uma vez que esta estratégia permite, além da atuação preventiva, a eliminação de produtos já registrados e preocupantes do ponto de vista dos efeitos adversos à saúde humana e o meio ambiente.

Entretanto, como no Brasil, muitos países se detêm na avaliação de produtos antigos, escolhidos à revelia, sem critérios objetivos, que, por serem numerosos, acabam por abarrotar a máquina administrativa.

Como o processo de avaliação de riscos não é simples, exigindo uma logística sofisticada por parte das instituições, a "escolha" de uma substância para ter seus riscos avaliados deve ter como referencial critérios técnicos claros (toxicológicos e ecotoxicológicos), e deve envolver diversos atores, como as indústrias produtoras de agrotóxicos, as organizações não governamentais e os sindicatos de trabalhadores rurais, que trarão os aspectos políticos e sociais para a decisão. Desta forma, estará sendo construída uma base que pode garantir um resultado representativo, especialmente quanto à sua aceitabilidade social.

Vários países têm modificado a visão do registro, priorizando a avaliação de produtos novos e utilizando referenciais de custo-benefício para a tomada de decisão. 
Este aprimoramento dos mecanismos de gerenciamento dos agrotóxicos vem sendo estimulado pelas restrições, proibições e alertas sobre os riscos em nível internacional, além das iniciativas das Organizações das Nações Unidas.

\subsection{Gerenciamento de Riscos de Agrotóxicos nos Estados Unidos}

A referência legal norte americana para regular os agrotóxicos é a Lei Federal denominada Federal Insecticide, Fungicide, and Rodenticide Act - FIFRA (sigla em inglês), datada de 1947. A Agência de Proteção Ambiental dos Estados Unidos USEPA (sigla em inglês) e os estados, geralmente por meio do Departamento de Agricultura Estadual, registram ou licenciam agrotóxicos para uso no país.

O Centro de Programa de Agrotóxicos (Office of Pesticide Programs), da USEPA, junto com o Centro de Prevenção, Agrotóxicos e Substâncias Tóxicas (Office of Prevention, Pesticides, and Toxic Substances - OPPTS), trabalha com 10 centros regionais e outros centros do Programa da Agência, em vários assuntos relacionados aos agrotóxicos.

O Centro de Substâncias Tóxicas - OTS (sigla em inglês), também da USEPA, é responsável pela implementação das determinações contidas na Lei de Controle de Substâncias Tóxicas (Toxic Substances Control Act - TSCA), de 1976, e tem a finalidade de proteger a saúde humana e o meio ambiente de riscos "não razoáveis" causados por substâncias químicas de $\underline{\text { uso }}$ industrial e misturas (MAKI e SLIMAK, 1990).

A FIFRA é a referência legislativa para a regulação, venda, distribuição e uso de agrotóxicos e define que o produto deve obter um registro antes de ser manufaturado, transportado e vendido. Esta lei autoriza a USEPA a revisar e registrar agrotóxicos para usos específicos, e também dá a ela a competência para suspender ou cancelar o registro de agrotóxicos, se informações comprovarem que o seu uso acarreta riscos não razoáveis (unreasonable risks).

A tomada de decisão da USEPA baseia-se na avaliação risco-benefício, ou seja, avalia os riscos à saúde e ao meio ambiente pela exposição ao produto e os benefícios do seu uso para a sociedade e a economia (LAYNE, 1998; LEMES, 2003). 
No processo de registro de agrotóxicos a USEPA examina o(s) ingrediente(s) ativo(s) de um agrotóxico; o local ou a cultura em que será utilizado; a quantidade, freqüência e período de uso e, as práticas de estocagem e disposição. Visa assegurar que eles não causem efeitos não razoáveis (unreasonable) para o homem, o meio ambiente e as espécies não-alvo. Segundo MAKI e SLIMAK (1990) riscos não razoáveis, à luz da legislação dos Estados Unidos, significa qualquer risco para o ser humano ou o meio ambiente, considerando os custos e benefícios econômicos, sociais e ambientais do uso do agrotóxico.

Segundo ROGERS (2003), assim como na União Européia, o sistema federal americano avalia a substância em relação aos diferentes meios e compara com padrões o que, segundo o autor, também torna o sistema caro, discutível do ponto de vista de critérios de seleção de testes e lento.

O processo de registro nos EUA é iniciado com a entrada na USEPA, de uma série de documentos que são analisados pela Agência. O produto é avaliado quanto ao seu perigo para à saúde humana e o meio ambiente.

Dependendo da classe do agrotóxico, e da prioridade definida para ele, o processo de revisão pode demorar alguns anos. Biopesticidas e agrotóxicos não convencionais de risco reduzido (safer products) freqüentemente recebem tratamento diferenciado, com o tempo de avaliação mais reduzido em relação aos outros. Segundo GARCIA (2001), em 1997, dos 28 novos ingredientes ativos registrados, 19 foram considerados de risco reduzido (safer products).

Como parte do registro, os produtos agrotóxicos são classificados como "para uso geral”, "para uso restrito", ou "ambos”. A classificação baseia-se na avaliação das características do produto versus sua indicação de uso.

Com relação aos novos agrotóxicos, ou novos usos, a lei federal define que, antes da venda ou distribuição, o requerente deve solicitar o registro ou licença da USEPA. A Agência certifica-se, por meio mais de até 100 diferentes tipos de estudos e testes científicos que, quando utilizado de acordo com as recomendações, existe uma certeza razoável de que o produto não irá causar efeitos adversos ao homem e ao meio ambiente. Dependendo dos resultados dos estudos, poderão ser solicitados testes adicionais (LAYNE, 1998). 
A maioria dos estados americanos revisa a rotulagem, no sentido de averiguar se está de acordo com as normas federais e com as restrições estaduais. De acordo com a FIFRA, os estados têm autonomia para tal e podem incluir usos e restrições para agrotóxicos já registrados, de acordo com necessidades locais, mas não podem autorizar o registro de ingredientes ativos novos.

Para agrotóxicos que podem ser utilizados diretamente em alimentos ou em culturas consumidas in natura, a USEPA fixa um limite máximo de resíduo permitido no alimento, que é periodicamente reavaliado, conforme o disposto na Lei de Proteção a Qualidade Alimentar (Food Quality Protection Act - FQPA), de 1996.

Os limites de resíduos estabelecidos pela Agência consideram a exposição global do público ao agrotóxico (todas as possíveis rotas de exposição) e são monitorados para assegurar que não serão excedidos.

A legislação também estabelece limites de tolerância para os inertes, que são os ingredientes adicionados ao produto agrotóxico para fins agrícolas, sem finalidade de causar efeito em uma praga alvo. Os inertes são classificados segundo quatro categorias toxicológicas. Classe 1, que contém os ingredientes inertes de preocupação toxicológica; a Classe 2 , com outros inertes de potencialidade tóxica e/ou inertes com alta prioridade para serem testados; a Classe 3, com os inertes de toxicidade desconhecida; a Classe $4 \mathrm{~A}$, com os inertes que apresentam risco mínimo e a Classe $4 \mathrm{~B}$, com os ingredientes inertes para os quais USEPA tem informação suficiente para concluir que o uso em produtos agrotóxicos não afetará adversamente a saúde pública ou o meio ambiente.

A lei prevê o processo de re-registro de agrotóxicos (espécie de reavaliação) para assegurar que agrotóxicos antigos, cujo registro data de antes de novembro de 1984, satisfaçam aos padrões de segurança atuais. Este processo pode resultar na solicitação de, por exemplo, mudanças nas características do produto, como a alteração de solventes, ou restrições no uso, no sentido de proteger os consumidores, os trabalhadores e o meio ambiente. O cronograma de reavaliação de cada agrotóxico é publicado pela USEPA, estando atualmente disponibilizado o cronograma 2004 2008 (USEPA, 2004a). Os processos de re-registro e de reavaliação dos limites de 
tolerância são caracterizados como uma ação de gerenciamento de riscos de agrotóxicos antigos.

A avaliação de riscos da USEPA caracteriza-se por ser dinâmica e estar sempre em constante aprimoramento com a aplicação de novas metodologias científicas. ANDERSON e HILAIRE (2004) fizeram um levantamento da experiência dos Estados Unidos na aplicação da avaliação de riscos em nível regulatório e concluem que, com relação à avaliação de risco à saúde, antes dos anos 70 as agências regulatórias eram independentes para avaliar o risco que subsidiava a tomada de decisão, mas uma série de eventos levou à coordenação e padronização dos procedimentos, incluindo a revisão por comitês científicos independentes.

O método padrão utilizado pela OPP [Office of Pesticide Program] da USEPA para caracterizar o risco, é o método do quociente, expresso pela concentração da exposição dividida pela concentração que causa efeito, gerando o Quociente de Risco - RQ (sigla em inglês), ou seja, a razão entre a concentração ambiental estimada (estimativa de exposição) de um produto químico e o nível de efeito de toxicidade, para uma dada espécie (por exemplo, $\mathrm{CL}_{50}$ ).

O RQ é um índice/indicador ou medida da condição dos efeitos adversos potenciais. Os referenciais para comparação do índice RQ são os níveis estabelecidos pela USEPA, denominados Level of Concern - LOC (sigla em inglês).

É reconhecido que RQs e LOCs são úteis na etapa de triagem/seleção, pois permite ao gestor de risco rapidamente identificar os agrotóxicos com maiores riscos.

A USEPA considera que o método do quociente é um método determinístico que serve como uma medida intermediária para o método probabilístico. Deste modo, a Agência mantém, geralmente utilizando-se de comitês científicos assessores, uma produtiva discussão sobre os métodos determinísticos e a migração paulatina para métodos probabilísticos (USEPA, 2004b).

O método do quociente permanece é o componente fundamental no gerenciamento de riscos de agrotóxicos para registro e re-registro, sendo útil para triagem de agrotóxicos, ao passo que, para as substâncias químicas preocupantes a utilização de ferramentas probabilísticas é necessária. 
Desde o final dos anos 90, aproximadamente em 1997, a USEPA vem discutindo os prós e contras do método probabilístico. Com relação à avaliação de riscos ecológico, em 1997 a Agência criou um comitê da FIFRA para discutir métodos para esta avaliação, denominado ECOFRAM (sigla em inglês). Este comitê apresentou propostas para modificações na avaliação de riscos, com a inserção de etapas graduais de aprofundamento da avaliação [tiers] variando de simples avaliações determinísticas até uma avaliação probabilística altamente específica.

A proposta consta de quatro níveis de avaliação: o nível I refere-se a uma simples triagem [screening]; o nível II trata da avaliação preliminar de probabilidade e magnitude dos efeitos, e os níveis III e IV tratam da avaliação mais específica, com foco em cenários de exposição. Esta proposta vem sendo discutida, aprimorada e implementada, no âmbito da FIFRA. Já foram desenvolvidos modelos aquáticos e terrestres para avaliar o agrotóxico Carbofuran, e estão sendo finalizados os modelos que serão utilizados no nível II (USEPA, 2004b).

As discussões realizadas pelos vários comitês assessores da FIFRA vêm servindo de apoio para que o Escritório de Avaliação de Agrotóxicos (OPP) incorpore paulatinamente ferramentas e métodos probabilísticos para avaliação de riscos de agrotóxicos.

Apesar do apoio dos reguladores e assessores da USEPA, eles alegam que para a utilização dos métodos probabilísticos são necessários treinamento e diálogo constante e freqüente, para assegurar o entendimento dos modelos, suposições e limitações (USEPA, 2004b).

\subsection{Gerenciamento de Riscos de Agrotóxicos na União Européia}

Na União Européia - UE existem várias categorias de substâncias e para cada delas foi desenvolvida uma legislação específica. As principais categorias são: substâncias novas, substâncias existentes, produtos de proteção de planta, biocidas, cosméticos, aditivos de alimentos e aditivos comestíveis.

Os agrotóxicos são divididos em dois grupos: produtos para proteção de plantas e produtos biocidas, sendo que ambos necessitam de avaliação e autorização antes da entrada no mercado. Os agrotóxicos estão sujeitos à proibição ou restrições, 
regulamentos relacionados ao comércio internacional, bem como à legislação relativa às águas (EUROPEAN COMMISSION, 2001).

O atual sistema distingue entre "substâncias existentes", que são aquelas substâncias em utilização na União Européia antes de setembro de 1981, e enumeradas no Inventário Europeu das Substâncias Químicas Existentes no Mercado ${ }^{12}$, e "substâncias novas", aquelas que foram colocadas no mercado após esta data. Existem atualmente cerca de 2.700 substâncias classificadas como "novas" (BROWN, 2003; ROGERS, 2003).

A Diretiva 67/548 relativa à classificação, embalagem e rotulagem de substâncias perigosas, que entrou em vigor na UE em 1981, introduziu o procedimento de notificação, i.e., todas as substâncias novas a serem fabricadas ou comercializadas devem ser notificadas. A notificação deve ser acompanhada de um conjunto de dados sobre identidade, produção, uso e propriedades da substância. São obrigatórios ensaios e a avaliação dos danos à saúde humana e o meio ambiente antes da colocação no mercado de quantidades superiores a $10 \mathrm{~kg}$ (CCE, 2004). Para substâncias colocadas em quantidades mais elevadas, é necessário proceder a um ensaio mais exaustivo sobre os efeitos crônicos e de longo prazo.

A avaliação de riscos das substâncias é realizada de acordo com uma metodologia harmonizada, contida em documentos técnicos (TGD, Technical Guidance Documents). Modificações recentes nos TGD incorporaram a avaliação de risco para o ambiente marinho e a solicitação de dados relativos à toxicidade reprodutiva, relacionados à questão ambiental e de saúde humana, respectivamente (BODAR et. al. 2002).

Calcula-se que atualmente existam mais de 30.000 substâncias comercializadas em quantidades superiores a uma tonelada. Cerca de 140 destas substâncias foram identificadas como substâncias prioritárias, ou seja, que requerem atenção imediata devido aos efeitos potenciais à saúde humana ou meio ambiente, e estão sujeitas a uma avaliação exaustiva dos riscos, efetuada pelas autoridades dos Estados-Membros (CCE, 2004).

12 Inventário que contém as substâncias presentes se no mercado da UE entre 1 de Janeiro de 1971 e 18 de Setembro de 1981. Trata-se de uma lista fechada de 100106 substâncias químicas "existentes" regidas pelo Regulamento 793/93 (CCE, 2004). 
ROGERS (2003) cita que a distinção entre substâncias novas e existentes, no âmbito da União Européia, gerou uma complexa rede de instrumentos legais diferenciados para cada uma das classes de substâncias tais como, regras de importação e exportação, e procedimentos de avaliação de riscos.

Com relação às substâncias existentes, que representam mais de $99 \%$ da quantidade total de todas as substâncias no mercado, elas estão sujeitas aos requisitos diferenciados de ensaios, dependendo do volume de produção ou importação.

Em 1993, foi definida que a avaliação e controle das substâncias existentes devem ser realizados em quatro etapas: (1) coleta de dados, (2) fixação de prioridades, (3) avaliação de risco, e (4) redução de risco.

$\mathrm{Na}$ fase de coleta de dados, para as substâncias químicas existentes de Alto Volume de Produção - HPVCs ${ }^{13}$, são solicitados dados sobre volume, uso, destino, e (eco)toxicologia da substância. As empresas que produzem ou importam substâncias existentes em quantidades entre 10 e 1000t por ano (substâncias existentes com Baixo Volume de Produção ou LPVCs) devem submeter um conjunto de dados mais resumido. A fixação de prioridade, etapa (2), é definida a partir das informações apresentadas na etapa (1).

A avaliação de risco para substâncias químicas novas e prioritárias segue a seguinte seqüência: (1) identificação de perigo, (2) avaliação dose (concentração)-resposta (efeito), (3) avaliação de exposição, e (4) caracterização de risco.

A caracterização de risco baseia-se em uma comparação quantitativa da identificação do perigo, e avaliação da dose-resposta e da exposição, com referenciais de proteção pré-estabelecidos. Os princípios de avaliação de risco para substâncias químicas novas e existentes estão apresentados na Diretiva 93/67/EEC e no Regulamento da Comissão 1488/94, respectivamente.

A avaliação de risco ecológico tem como meta a proteção do ecossistema aquático (inclusive sedimento), ecossistema terrestre, predadores superiores, microorganismos nos sistemas de tratamento de esgoto e a atmosfera. A estrutura baseia-se no cálculo das taxas de emissão de substâncias para as diferentes etapas do ciclo de vida, e a

13 Aquelas que foram importadas ou produzidas em quantidades superiores a 1000t/ano e produzidas/importadas entre 1990 e 1994. 
utilização destes resultados para calcular as Concentrações Ambientais Previstas PEC (sigla em inglês), tanto em escala regional quanto local. O nível de risco é a relação entre a PEC e a Concentração Prevista Para Não Efeito - PNEC (sigla em inglês).

A avaliação de riscos à saúde humana objetiva proteger trabalhadores, consumidores, e o público em geral da exposição indireta e, como muitos outros sistemas existentes, está baseado no denominado "Livro Vermelho" publicado em 1983, pelo NRC (BODAR, et al. 2002).

O nível de risco à saúde humana é a relação do NOAEL e as medidas de exposição estimadas ou medidas. Estas medidas geram um índice de risco, uma estimativa pontual. Este índice é denominado no TGD como Índice/Coeficiente de Caracterização do Risco [Risk Characterization Ratios] - RCR.

Todos os dados que são submetidos para análise devem ser apresentados em um formato eletrônico específico, denominado "Dados Eletrônicos Harmonizados HEDSET" (sigla em inglês), que é gerenciado pelo "Banco de Dados Internacional de Informações Químicas - IUCLID” (sigla em inglês). Os dados devem ser atualizados pela empresa pelo menos uma vez a cada três anos. Para auxiliar a avaliação de risco, foi desenvolvido um software para a tomada de decisão, denominado "Sistema da União Européia para a Avaliação de Substâncias" - EUSES (sigla em inglês). A avaliação de risco executada para substâncias químicas novas e existentes é, em princípio, válida para todos os países na União Européia.

Devido às diferenças existentes dentre os países, principalmente com relação aos cenários de exposição, na fase de avaliação da exposição são aplicados cenários de exposição denominados de "genéricos". Nestes cenários é assumido que as substâncias são emitidas em um ambiente modelo não real, predefinido de acordo com características ambientais, que podem ser valores médios ou valores do pior caso juntamente com situações européias médias.

Dados disponíveis, isto é, emissões locais específicas ou dados de monitoramento, podem ser subseqüentemente utilizados para revisar as concentrações calculadas. Geralmente esta metodologia é pertinente para substâncias químicas existentes. 
A avaliação de risco considera o "pior caso razoável", definido como "razoavelmente desfavorável, mas não irreal", porém, como já discutido, o grau de conservacionismo nas avaliações determinísticas atuais é desconhecido.

BODAR, et al. (2002) citam trabalhos onde os resultados de avaliações determinísticas de riscos ambientais para o Bibutil ftalato (phthalate de dibutyl DBP), encontrado em produtos cosméticos como o esmalte e os sprays de cabelo, realizada no Reino Unido, foram comparados com avaliações probabilísticas e a análise feita para exposição ambiental de humanos não confirmou o pior caso da avaliação determinística.

O resultado de cada avaliação de risco é apresentado na forma de conclusões padrões, que indicam se há necessidade de ações adicionais ou de mais informações e/ou testes, e indicam as medidas para redução de risco.

Para a redução do risco são considerados aspectos como a análise custo-benefício, a avaliação de alternativas e a percepção do risco.

Atualmente, a responsabilidade pela avaliação é do governo e não das empresas que produzem, importam e utilizam as substâncias. A legislação exige que os fabricantes e importadores de substâncias forneçam informações, mas não exige informações dos utilizadores a jusante (utilizadores industriais e formuladores), o que torna impossível a obtenção de informação sobre a utilização das substâncias e, conseqüentemente, da exposição decorrente desta.

Quanto aos testes, a decisão sobre a realização de ensaios depende da apreciação de um comitê. Entretanto, testes mais complexos só podem ser exigidos das empresas após as autoridades terem comprovado que uma substância pode representar um risco grave. Como esta comprovação é praticamente impossível de obter, até o momento, apenas um pequeno número de substâncias foi avaliado quanto ao seu risco.

Com relação aos agrotóxicos, a regulamentação atual da UE para os denominados Produtos para Proteção de Plantas (PPP), visa à harmonização dos programas nacionais dos Países Membros, com relação aos banimentos e/ou restrições de certos ingredientes ativos de alto risco, resíduos em alimentos, classificação e rotulagem. 
Para harmonizar exigências e procedimentos sobre o registro, bem como atender às crescentes pressões políticas e da opinião pública, a Comunidade Européia tem discutido diretrizes sobre a questão. A base do sistema de registro é uma lista onde constam os ingredientes ativos permitidos para registro pelos países membros, construída a partir da revisão de cerca de 850 i.a. comercializados na UE (FRAGOMENI, 1997).

O registro de agrotóxicos é regido pela Diretiva 91/414/EEC relativa aos Produtos para Proteção de Plantas e pela Diretiva 98/8/EEC, para produtos biocidas. Os agrotóxicos existentes são revisados por meio do Regulamento 3600/93.

A Diretiva 91/414/EEC trata da avaliação de agrotóxicos sob os aspectos de proteção do consumidor e do trabalhador, da disseminação/especiação e comportamento no meio ambiente e de ecotoxicologia (EUROPEAN COMMISSION, 1997), além de estabelecer regras comuns para serem aplicadas na aprovação ou rejeição de um ingrediente ativo (i.a.) ou de um produto formulado.

As exigências para obter a autorização e os critérios para a avaliação e tomada de decisão, que devem ser aplicados por todos os Estados Membros, são apresentados no Anexo VI da Diretiva; os dados que devem ser apresentados pela empresa para solicitação da autorização estão no Anexo II, para o ingrediente ativo (i.a.), e no Anexo III para o produto formulado.

GARCIA (2001) cita que o desenvolvimento científico das técnicas de avaliação de riscos vem promovendo o aprimoramento da avaliação da segurança e eficácia dos agrotóxicos na UE, e que o grau de exigência para avaliação e registro varia entre os países, no que se refere às questões ambientais, mas que existe uniformidade quanto aos aspectos toxicológicos.

A priori, a implementação da Diretiva 91/414 deveria eliminar do mercado europeu os agrotóxicos de maior risco e, conseqüentemente, reduzir os níveis de risco do seu uso, mas a discussão sobre a eficácia da Diretiva indica que isto não ocorreu e que várias áreas ainda não foram suficientemente implementadas (EUROPEAN COMMISSION, 1997 e 1999).

Como já citado, uma das dificuldades encontradas na UE para avaliar as substâncias químicas de forma harmonizada decorre de diferenças ambientais entre os países. 
Com relação aos agrotóxicos, isto ocorre também por causa dos diferentes hábitos de dieta. Segundo VISENTIN et al. (2003) o controle de resíduos de agrotóxicos em alimentos na UE é realizado em duas operações paralelas, mas em estreita coordenação com a avaliação do ingrediente ativo (i.a). As duas operações são (1) a definição do limite máximo de resíduos, LMRs [Maximum Residue Limits] - MRLs (sigla em inglês) e, (2) gerenciamento dos programas de monitoramento de resíduos de agrotóxicos em alimentos.

Em março de 2003, foi apresentada e aprovada a proposta de harmonização dos LMRs dos agrotóxicos permitidos para produtos de origem vegetal e animal, no âmbito da Comunidade, eliminado as inconsistências comerciais resultantes do fato de cada Estado Membro definir seus próprios LMRs (VISENTIN et al. 2003). Esta determinação deve entrar em vigor em janeiro de 2005 (EUROPEAN COMMISSION, 2003).

Quanto ao uso de modelos para avaliação de agrotóxicos, a UE carece de uma coordenação central, e de orientações para avaliar os dados de monitoramento e dados experimentais, conseqüentemente resultados de diferentes modelos de cálculo podem ser considerados no processo de registro.

A Diretiva 91/414 faz referência geral ao uso de modelos adequados, "validados" no âmbito da Comunidade. Entretanto, apesar de não recomendar um modelo específico, uma vez que não existem modelos validados, já existem modelos sendo utilizados para avaliar o comportamento ambiental de substâncias químicas (EUROPEAN COMMISSION, 1997).

De forma geral, a política relacionada às substâncias químicas na UE é criticada por ser ineficiente na geração de conhecimentos sobre as propriedades e utilização das substâncias existentes, lentidão do processo e alto consumo de recursos. Também é criticada por dividir as substâncias em muitas categorias de uso.

Em 2002, foi estabelecido, no âmbito da UE, o $6^{\circ}$ Programa de Ação Ambiental [6th Environmental Action Program] - 6EAP (sigla em inglês), com o lema "Environment 2010: Our Future, Our Choice". Este programa apresenta metas a serem atingidas na próxima década e orientações estratégicas para a política ambiental, levando em 
consideração a expansão da UE e inclui a revisão do quadro regulamentar, em especial da Diretiva 91/414/CEE.

No 6EAP são identificadas quatro grandes áreas relacionadas ao meio ambiente, que necessitam de aprimoramento, uma delas é "meio ambiente, saúde e a qualidade de vida"; e sete estratégias temáticas: proteção do solo; proteção e conservação do meio ambiente marinho; uso sustentável de agrotóxicos; poluição do ar; meio ambiente urbano; uso e gerenciamento sustentável dos recursos e; reciclagem de resíduos.

Dentre os problemas relacionados ao uso sustentável de agrotóxicos está a necessidade de minimização dos perigos e riscos para o meio ambiente e saúde humana, sugerindo-se para isto, dentre outras ações: (1) estabelecimento de planos nacionais de redução dos riscos e redução da dependência de produtos químicos para o controle de pragas; (2) melhor conhecimento dos riscos por meio, por exemplo, de vigilância da saúde dos trabalhadores agrícolas e consumidores mais sensíveis (estudos epidemiológicos), e coleta de dados sobre os incidentes com conseqüências para a saúde e o meio ambiente (registro e análise centralizados dos incidentes); (3) substituição das substâncias mais perigosas por outras mais seguras, incluindo alternativas não químicas.

Com relação ao aspecto internacional, o 6EAP sugere controlar e avaliar melhor as exportações ou doações de produtos químicos e a gestão dos estoques obsoletos desses produtos. Ressalta a importância da aplicação dos procedimentos previstos nas Convenções de Roterdã (PIC) e de Estocolmo (POPs).

Além da rotina existente, de avaliação e atualização da Diretiva 91/414 e elaboração de novos regulamentos, a sistemática de avaliação de substâncias químicas na União Européia está em um processo radical de modificação. Em 2001, foi proposto o sistema denominado REACH - Registration, Evaluation and Authorization of Chemicals, que é o elemento chave da atual estratégia política para substâncias químicas na UE.

Uma das justificativas para a nova proposição é justamente a preocupação com a falta de conhecimentos sobre o impacto de muitas substâncias químicas na saúde humana e no ambiente. Segundo o chamado Livro Branco [White Paper] (EUROPEAN COMMISSION, 2001), onde foi apresentada a estratégia, o novo 
procedimento deve garantir a necessária proteção da saúde humana e do meio ambiente, assegurando simultaneamente o funcionamento do mercado interno e a competitividade da indústria química.

O REACH é um sistema de controle de substâncias que propõe que as substâncias existentes e novas, iniciando pelas novas e gradualmente incluindo as existentes até 2012, estejam submetidas a um mesmo procedimento de avaliação. Os ensaios a serem solicitados, dependerão da periculosidade, utilização, exposição e quantidades produzidas ou importadas.

Primeiramente, todas as substâncias químicas produzidas em quantidades superiores a uma tonelada anual devem ser registradas em uma base de dados central, para as quais será dada atenção especial aos efeitos crônicos de longo prazo.

Esta política vem gerando calorosas discussões, não tanto quanto às questões técnicas, mas devido aos aspectos comerciais.

Os Estados Unidos faz ressalvas quanto às implicações econômicas que ela pode gerar e a classifica como um sistema regulatório complexo e de alto custo para ser implementado. O principal obstáculo diz respeito aos entraves comerciais que serão gerados, além do fato de que esta política representa o distanciamento da UE da meta de maior harmonização entre os países da OECD.

O Brasil vem discutindo, no âmbito do Ministério do Desenvolvimento, Indústria e Comércio Exterior e associações de empresas do setor químico, o impacto da estratégia do chamado Livro Branco. As discussões giram principalmente em torno das questões comerciais relacionadas à reserva de mercado e as barreiras não tarifárias.

\subsection{Gerenciamento de Riscos de Agrotóxicos no Brasil}

Conforme apresentado, o gerenciamento de agrotóxicos, em nível governamental federal, tem seus principais aspectos definidos pelos Ministérios da Saúde, do Meio Ambiente e da Agricultura. A Lei 7.802/89 impôs ao setor executivo um mecanismo altamente complexo e rigoroso que envolve os três órgãos federais no processo de aprovação, para obtenção do registro de um agrotóxico no Brasil. 
Os requerentes devem realizar numerosos testes, cujos resultados são avaliados tendo como referência critérios bastante restritivos, além de serem exigidas informações sobre o teor dos produtos, os rótulos e bulas a serem utilizadas, bem como sobre os procedimentos de uso e de segurança, dentre outras informações.

Atualmente, são exigidas informações sobre a composição quali-quantitativa do produto, incluindo concentração total de ingredientes ativos, inertes e outros; identidade dos componentes da formulação; concentração e toxicidade das impurezas ou subprodutos do produto técnico; informações sobre as propriedades físicoquímicas, tais como, grau de pureza, estado físico, aspecto, cor, odor, $\mathrm{pH}$, volatilidade, pressão de vapor, corrosividade, entre outros.

O órgão federal competente do Setor Saúde, ANVISA, solicita testes toxicológicos toxicidade aguda oral (DL50), dérmica (DL50), inalatória (CL50) e ocular; teste de irritação e sensibilização cutânea; toxicidade dérmica 21/28 dias, toxicidade de curto prazo (duas espécies de animais, uma das quais não roedora); toxicidade de longo prazo; potencial carcinogênico; efeitos sobre a reprodução e prole (em 3 gerações sucessivas); efeitos teratogênicos, mutagênicos e neurotoxicidade retardada. Solicita também testes de metabolismo e vias de excreção, bem como a meia vida biológica em animais de laboratório e a toxicidade dos metabólitos, caso estes sejam diferentes nas plantas e animais. Também solicita ensaios sobre resíduos.

A ANVISA disponibiliza no seu endereço eletrônico na Internet, o "Manual de Procedimentos para Análise Toxicológica de Produtos Agrotóxicos, seus componentes e afins". Este manual apresenta informações sobre a classificação toxicológica, precauções de uso, indicação de risco, advertências que devem constar no rótulo e bula, além dos documentos e estudos que devem ser apresentados pelo interessado em adquirir o registro de produtos (ANVISA, 2004).

O órgão federal competente do Setor Ambiental, IBAMA, de acordo com a Portaria 84/96, solicita testes sobre as características físico-químicas - estado físico, aspecto, cor e odor; identificação molecular; grau de pureza; impurezas metálicas; ponto/faixa de fusão e ebulição; pressão de vapor; solubilidade; $\mathrm{pH}$; hidrólise; fotólise; coeficiente de partição (n-octanol/água); densidade e outros. Com relação à toxicidade para organismos não-alvo, são solicitados testes para microorganismos; 
algas; organismos do solo; abelhas; microcrustáceos; peixes; aves; plantas (fitotoxicidade para plantas não-alvo). São requisitados também testes sobre o comportamento no solo - biodegradabilidade, mobilidade e absorção/dessorção (IBAMA, 1996).

Com relação à toxicidade para animais superiores são solicitados testes de toxicidade aguda oral, inalatória, cutânea, para ratos e ocular para coelhos; toxicidade de curto prazo para cães e metabolismos e via de excreção bem como a meia vida biológica em animais de laboratório. Como no Setor Saúde, o Setor Ambiental também solicita testes sobre o potencial genotóxico, embriofetotóxico e carcinogênico.

O referencial para aprovação do registro é o potencial de perigo dos agrotóxicos. O IBAMA define a classificação quanto ao potencial de periculosidade ambiental e a ANVISA, a classe toxicológica.

Entretanto, apesar da legislação federal de agrotóxicos possuir várias citações sobre riscos, apenas a Portaria $n^{\circ}$ 84/1996 do IBAMA e o Decreto Federal no 4.074/2002 utilizam o conceito científico do termo, enquanto nos outros regulamentos o termo é utilizado como sinônimo de perigo.

Na Lei 7.802/89 - Lei dos agrotóxicos, apesar do termo "risco" ter sido utilizado sem preocupação quanto ao seu significado científico, mas com o significado de perigo, é mencionado em três oportunidades: Art. $3^{\circ}, \S 4^{\circ}$, no qual cita que devem ser tomadas providências a partir de alertas sobre riscos de agrotóxicos, emitidos por agências internacionais; no Art. $3^{\circ}, \S 6^{\circ}(a)$, em que exige a existência de métodos de desativação que impeçam que resíduos remanescentes provoquem riscos à saúde pública e ao meio ambiente e; no art $8^{\circ}$, em que define que as propagandas devem veicular informação sobre os riscos (BRASIL, 1989).

Com relação à Portaria 84/96, do IBAMA, no Artigo $2^{\circ}$, que instituiu o sistema avaliação de controle dos agrotóxicos, o termo risco também é mencionado.

“Art. $2^{\circ}$ - Instituir o Sistema Permanente da Avaliação e Controle dos Agrotóxicos, seus componentes e afins, que compreende os seguintes subsistemas: 
c) avaliação do risco ambiental” (IBAMA, 1996).

Os procedimentos previstos na Portaria 84/1996 são exclusivos para o IBAMA, ou seja, a Portaria cria o Sistema Permanente de Avaliação e controle de Agrotóxicos, apenas para o que se refere aos aspectos ambientais. Apesar disso, ou seja, os aspectos ambientais serem avaliados de forma unilateral pelo setor ambiental, os parâmetros utilizados pelo IBAMA incluem testes relacionados à saúde humana, como o potencial mutagênico, teratogênico e carcinogênico.

O Artigo $3^{\circ}$ mantém a avaliação de perigo para fins de classificação.

"Art. $3^{\circ}$ - A classificação quanto ao potencial de periculosidade ambiental [ppa] baseia-se nos parâmetros bioacumulação, persistência, transporte, toxicidade a diversos organismos, potencial mutagênico, teratogênico, carcinogênico, obedecendo à seguinte graduação:

Classe I - Produto Altamente Perigoso

Classe II - Produto Muito Perigoso

Classe III - Produto Perigoso

Classe IV - Produto Pouco Perigoso

Parágrafo Único. Aos agrotóxicos, seus componentes e afins, que se enquadrem em pelo menos um dos seguintes casos, será conferida a classificação de "Produto de Periculosidade Impeditiva à Obtenção de Registro",

a) não houver disponibilidade no País de métodos para sua desativação e de seus componentes, como preceitua a alínea a, do $\S 6^{\circ}$, do artigo $3^{\circ}$, da Lei 7.802 e inciso I, do artigo 22, do Decreto 98.816;

b) apresentar características mutagênicas, teratogênicas ou carcinogênicas referidas na alínea c, do $\S 6^{\circ}$, do artigo $3^{\circ}$, da Lei 7.802 e incisos III, IV e V, do artigo 22, do Decreto 98.816;

c) a classificação de ppa e/ou avaliação do risco ambiental indicarem índices não aceitáveis de periculosidade e/ou risco, considerando os usos propostos."(IBAMA, 1996) 
O sistema de avaliação do potencial de perigo ainda é um mecanismo oficial de classificação dos agrotóxicos. De certa forma este é o procedimento correto para uma primeira triagem dos produtos, que se baseia nas características intrínsecas dos produtos.

O Artigo $6^{\circ}$, da Portaria 84/96, define quando deve ser realizada a avaliação de riscos.

“Art. $6^{\circ}$ - A avaliação do risco ambiental, será realizada quando a classificação de periculosidade ambiental considerando os usos propostos caracterizar a necessidade da geração de informação de campo, ou quando, a critério do IBAMA, for verificada a sua necessidade.

$\S 1^{\circ}$ - A avaliação do risco ambiental será exigida das formulações já registradas ou a registrar, podendo implicar na alteração, suspensão ou cancelamento dos registros, quando a avaliação indicar a maximização ou minimização dos riscos ambientais previstos na classificação de potencial de periculosidade ambiental.

$\S 3^{\circ}$ - A necessidade da avaliação do risco ambiental das formulações, quando identificada, obrigará o registrante a apresentar termo de compromisso, conforme inciso I do anexo VI, dentro do prazo de 90 (noventa) dias previsto para a classificação de potencial de periculosidade ambiental, sendo que o não atendimento implicará no arquivamento do processo por despacho fundamentado.

$\S 6^{\circ}$ - As informações necessárias à elaboração do projeto para avaliação do risco ambiental são aquelas constantes no inciso II do Anexo VI, podendo ser acrescidas e/ou suprimidas, dependendo de cada situação a ser estudada." (IBAMA, 1996).

Este Artigo é o referencial para a utilização da avaliação de riscos no processo de gerenciamento de agrotóxicos. Entretanto, até o momento, não foram publicados resultados que tenham sido gerados a partir deste referencial. 
Quanto ao Decreto 4.074/2002, o mais recente instrumento legal para o gerenciamento de agrotóxicos, várias citações relativas à avaliação de riscos foram identificadas:

“Art. 2. Cabe aos Ministérios da Agricultura, Pecuária e Abastecimento, Saúde e do Meio Ambiente, no âmbito de suas respectivas áreas de competências.

II - estabelecer diretrizes e exigências objetivando minimizar os riscos apresentados por agrotóxicos, seus componentes e afins;" (BRASIL, 2002a)

As diretrizes e exigências deveriam estar representadas nas portarias, normas e regulamentos específicos que os órgãos publicam. Quanto à minimização dos riscos, os mecanismos de gerenciamento mais utilizados, na fase pós-registro, são as orientações constantes nos rótulos e bulas e as restrições quanto ao uso em algumas culturas, impostas a alguns produtos.

O Item VI do Artigo 2 e o Artigo 13, abordam a reavaliação para o seguinte contexto:

“Art $2^{\circ} \ldots$.

VI - promover a reavaliação de registro de agrotóxicos, seus componentes e afins quando surgirem indícios da ocorrência de riscos (destaque nosso) que desaconselhem o uso de produtos registrados ou quando o País for alertado nesse sentido, por organizações internacionais responsáveis pela saúde, alimentação ou meio ambiente, das quais o Brasil seja membro integrante ou signatário de acordos;

Art. 13. Os agrotóxicos, seus componentes e afins que apresentarem indícios de redução de sua eficiência agronômica, alteração dos riscos à saúde humana ou ao meio ambiente poderão ser reavaliados a qualquer tempo e ter seus registros mantidos, alterados, suspensos ou cancelados." (BRASIL, 2002a).

Os três órgãos deveriam estruturar-se para identificar os "indícios de ocorrência de riscos", fazendo com que a aplicação da reavaliação não seja apenas uma 
possibilidade remota. Até o momento, a ANVISA e o IBAMA promoveram reavaliação de vários produtos que são, na sua maioria, produtos antigos e já reconhecidamente problemáticos.

As determinações destes dois artigos do Decreto, além de estarem relacionadas ao Artigo $6^{\circ}$ da Portaria IBAMA 84/96, estão relacionadas, também, ao artigo 19 do próprio Decreto.

“Art. 19. Quando organizações internacionais responsáveis pela saúde, alimentação ou meio ambiente, das quais o Brasil seja membro integrante ou signatário de acordos e convênios, alertarem para riscos ou desaconselharem o uso de agrotóxicos, seus componentes e afins, caberá aos órgãos federais de agricultura, saúde e meio ambiente, avaliar imediatamente os problemas e as informações apresentadas.” (BRASIL 2002).

Até o momento, a maioria dos produtos reavaliados já foi alvo de ações internacionais. O heptacloro e o brometo de metila são citados em Convenções internacionais e já foram objetos de restrição. Alguns produtos agrotóxicos citados na Convenção PIC (PIC, 2004) já sofrem restrição ou são objetos de reavaliação. Todos os produtos listados como POPs na Convenção de Estocolmo (POPs, 2004), até o momento, já foram praticamente proibidos no país e apenas o heptacloro está em fase de eliminação.

A restrição ao registro, ou seja, um procedimento que seria aplicado diretamente aos novos produtos é citado no Artigo 31 do Decreto 4.074/02.

“Art. 31. É proibido o registro de agrotóxicos, seus componentes e afins:

I - para os quais no Brasil não disponha de métodos para desativação de seus componentes, de modo a impedir que os seus resíduos remanescentes provoquem riscos ao meio ambiente e à saúde pública;

II - para os quais não haja antídoto ou tratamento eficaz no Brasil;

III - considerados teratogênicos, que apresentem evidências suficientes nesse sentido, a partir de observações na espécie humana ou de estudos em animais de experimentação; 
IV - considerados carcinogênicos, que apresentem evidências suficientes nesse sentido, a partir de observações na espécie humana ou de estudos em animais de experimentação;

V - considerados mutagênicos, capazes de induzir mutações observadas em, no mínimo, dois testes, um deles para detectar mutações gênicas, realizado, inclusive, com uso de ativação metabólica, e o outro para detectar mutações cromossômicas;

VI - que provoquem distúrbios hormonais, danos ao aparelho reprodutor, de acordo com procedimentos e experiências atualizadas na comunidade científica;

VII - que se revelem mais perigosos para o homem do que os testes de laboratório, com animais, tenham podido demonstrar, segundo critérios técnicos e científicos atualizados; e

VIII - cujas características causem danos ao meio ambiente.

$\S 1^{\circ}$ Devem ser considerados como "desativação de seus componentes" os processos de inativação dos ingredientes ativos que minimizem os riscos ao meio ambiente e à saúde humana.

$\S 20$ Os testes, as provas e os estudos sobre mutagênese, carcinogênese e teratogênese, realizados no mínimo em duas espécies animais, devem ser efetuados com a aplicação de critérios aceitos por instituições técnicocientíficas nacionais ou internacionais reconhecidas." (BRASIL, 2002a).

O procedimento de restrição no registro de produtos novos é uma abordagem de cunho precaucionista, considerada uma abordagem adequada para o gerenciamento. Entretanto, até o momento não houve divulgação de negativa de registro pelos motivos listados no Artigo 31.

O conflito entre os termos risco e perigo aparece neste texto. O Item I destaca que os resíduos remanescentes dos agrotóxicos não devem provocar riscos, enquanto o Item VII destaca que os produtos não podem ser mais perigosos para o homem do que os testes de laboratório tenham podido demonstrar. 
A determinação de que a avaliação de risco deve ser implementada é claramente definida no Artigo 95:

“Art. 95. Fica instituído o Comitê Técnico de Assessoramento para Agrotóxicos, com as seguintes competências:

III - elaborar, até 31 de dezembro de 2002, rotinas e procedimentos visando à implementação da avaliação de risco de agrotóxicos e afins; (BRASIL, 2002a).”

Apesar desta determinação, até o momento não existe documento legal, dos três órgãos envolvidos, sobre o tema.

Após a obtenção do registro, as atividades relacionadas ao gerenciamento dos agrotóxicos no País estão divididas entre diversas áreas do Poder Público. Além dos três Ministérios já citados, alguns órgãos se destacam por terem responsabilidades em determinadas etapas do ciclo de vida dos produtos.

A Figura 9 apresenta as etapas do ciclo de vida de um agrotóxico, destacando àquelas que devem ser consideradas no gerenciamento, após a emissão do registro.

O Ministério dos Transportes atua no gerenciamento dos riscos associados ao transporte de substâncias perigosas e o Ministério do Trabalho atua no controle e regulamentação dos riscos relacionados às atividades de trabalho.

Na planta da fábrica, o processo industrial geralmente está sujeito aos regulamentos voltados para a prevenção de acidentes, tanto com relação ao trabalhador quanto ao meio ambiente do entorno.

Após o registro, ao sair da fábrica, o produto deve ser transportado até formuladores, revendedores e o usuário, sendo neste momento, regulamentado por normas relativas ao transporte de produtos perigosos. Para a comercialização existem regras sobre rotulagem e mecanismos de controle, como o receituário agronômico.

Os mecanismos de gerenciamento na comercialização, no transporte e na distribuição são geralmente baseados em regulamentos normativos de comando e controle, cujo atendimento depende da fiscalização do Estado, ou seja, do aparato institucional. 
Este tipo de controle tende a tirar do produtor original (o que solicitou o registro) parcela da responsabilidade pelos possíveis impactos dos produtos, uma vez que ele só será acionado caso o País possua capacidade institucional para identificar o problema.

FIGURA 9 Etapas do gerenciamento pós-registro de agrotóxicos, no Brasil.

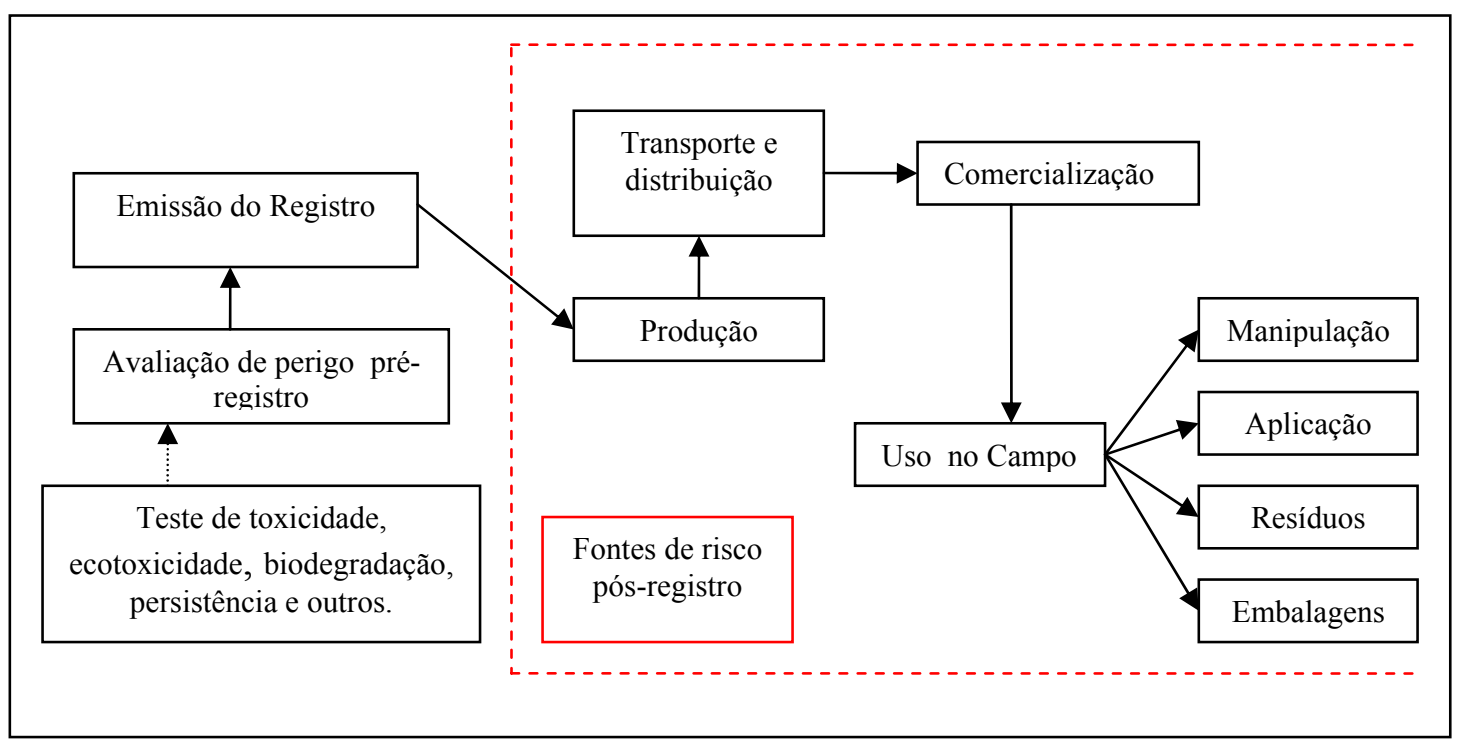

Além das etapas pós-registro já mencionadas, temos o gerenciamento no campo, ou seja, onde são aplicados os produtos. Este gerenciamento exige considerações complexas, por ser dependente de peculiaridades ambientais do local, das condições de uso, da população envolvida na sua aplicação, no tipo de cultura, no manejo empregado, dentre outros fatores.

A vulnerabilidade social, o que significa baixa escolaridade, trabalho precoce e falta de informação, contribui para o agravamento do problema. MOREIRA et al. (2002), citam que, no campo, os determinantes sócio-econômicos, a percepção do risco e a comunicação são fatores de amplificação ou redução dos impactos. Neste caso as ações para a redução do risco são dependentes de iniciativas compartilhadas entre o governo, o setor privado, o comerciante, o usuário e, também, a população afetada de forma indireta (consumidores). 
Como mostrado na Figura 9, o processo de gerenciamento de agrotóxicos tem uma única "entrada" (registro), que coloca o produto no mercado. A partir deste ponto, os mecanismos de feed back sobre o produto aprovado dependem exclusivamente do Estado ter capacidade para identificar a necessidade de uma reavaliação, ou seja, do retorno à etapa inicial do processo.

Esta forma de gerenciamento, observado também na maioria dos países em desenvolvimento, propicia a permanência de produtos de alta toxicidade no mercado. Conforme afirma MORAES (1994), o Brasil não tem tradição em planejar ou elaborar políticas integradas. Deste modo, a distribuição excessiva de competências, apesar de propiciar a participação dos setores que realmente necessitam atuar, desintegra o processo de gerenciamento de agrotóxicos, tornando-o frágil para tratar uma questão tão complexa e tão necessária ao nosso País (NARDOCCI, 1999).

Esta situação perpetua o cenário, já citado, de aumento do número de produtos registrados e de vendas, as acompanhado pelo aumento das intoxicações. 


\section{CONVENÇÕES POPS E PIC}

Ultimamente a proliferação de convenções internacionais em diferentes áreas, vem afetando a agenda política dos governos nacionais, principalmente porque, uma vez ratificadas, elas se tornam instrumentos legais nacionais e impõem aos Países-Parte modificações na legislação e obrigações tanto de ordem técnica como econômica e social.

A proliferação de tratados, declarações e convenções internacionais são um indicativo da forte influência política das prioridades definidas em nível internacional (COSTA, 1998).

Com relação à saúde e meio ambiente, os riscos da sociedade atual, de natureza sistêmica e globalizada, justificam de forma geral a existência de convenções intergovernamentais, principalmente pela complexidade em torno da proteção ambiental e da saúde humana, advinda destes riscos. LEITE e AYALA (2002, p. 23) afirmam que a proteção ao meio ambiente envolve exigências de dimensões interplanetárias, demandando instrumentos em nível internacional ou intercomunitário, e não isoladamente no interior do Estado de direito.

Esta exigência é reconhecida na Portaria 84/96 do IBAMA, um dos principais instrumentos da legislação federal relacionada aos agrotóxicos, que determina no artigo 16 que:

“Art. 16 - Os procedimentos fixados em Resoluções decorrentes de Acordos ou Tratados Internacionais, dos quais o Brasil é signatário, seguirão as especificidades ali elencadas”. (IBAMA, 1996).

Durante a Reunião da Cúpula Mundial para o Desenvolvimento Sustentável, em 2002, foi afirmado que, a despeito de haver vários acordos multilaterais em vigor, a implementação e a obtenção de resultados concretos, que caracterizem a vontade política de transformar em realidade compromissos já assumidos, ainda está muito aquém do desejado.

Este também é o ponto de vista do Ministério do Meio Ambiente do Brasil, quando, na pessoa da Ministra, Senhora Marina da Silva, citou que a Convenção de 
Biodiversidade já produziu em nosso País políticas, decisões e programas importantes, mas acumula enorme déficit de implementação (MMA, 2003).

No Plano de Implementação adotado em Joanesburgo ${ }^{14} / 2003$ estão apresentadas as atividades que os países devem executar relativas à Agenda 21, incluindo ações relacionadas ao gerenciamento de substâncias químicas (UN, 2002 - pg. 19). Dentre as propostas para este setor estão a ratificação e implementação das convenções internacionais sobre substâncias químicas, especificamente a "Convenção sobre o Procedimento de Consentimento Fundamentado Prévio Aplicável a certos Agrotóxicos e Produtos Químicos Perigosos Objeto de Comércio Internacional” Convenção de Roterdã ou PIC (PIC, 2004), e a "Convenção de Estocolmo sobre Poluentes Orgânicos Persistentes" - Convenção de Estocolmo ou POPs (POPS, 2004.

Estas duas convenções definem procedimentos para o controle do comércio internacional (Convenção PIC), e para o controle / total eliminação (Convenção POPs) de substâncias listadas em seus textos, e possuem mecanismos para inclusão de novas substâncias utilizando-se critérios definidos.

A Convenção PIC entrou em vigor em 24 de fevereiro de 2004, e a Convenção POPs em 17 de maio de 2004, com seus procedimentos passando a ter valor legal nos Países-Parte.

O Brasil publicou a ratificação das Convenções PIC e POPs, em 7 de maio de 2004, por meio dos Decretos Legislativos nº 197 e 204 (BRASIL, 2004a; 2004b), respectivamente, publicados no Diário Oficial da União, de 10 de maio de 2004. A ratificação junto as Organizações das Nações Unidas ocorreu em 16 de junho de 2004, para ambas as Convenções.

A discussão sobre estas duas convenções foi incorporada a este trabalho por elas possuírem as seguintes características:

- Tratarem especificamente de substâncias químicas, em sua maioria agrotóxicos;

- Fazerem referência à necessidade de elaboração de avaliação de riscos das substâncias presentes no seu escopo;

14 Ver detalhes na Introdução deste trabalho (página 7). 
- O Brasil ser um País-Parte das convenções desde Junho de 2004.

\section{Convenção de Estocolmo sobre Poluentes Orgânicos Persistentes ${ }^{15}$}

Poluentes Orgânicos Persistentes (POPs) são compostos orgânicos representados por compostos aromáticos, poliaromáticos e alicíclicos clorados. No conjunto destas substâncias estão inseridos os agrotóxicos, os produtos industriais e os produtos secundários de origem industrial, também chamado de não-intencional por serem sub-produtos formados como conseqüência de um processo químico de síntese.

Devido às suas características fisico-químicas, os POPs são reconhecidos como substâncias persistentes, ou seja, que permanecem no ambiente por longos períodos de tempo sem sofrer processos de degradação que levem à redução do seu potencial de dano ao ser humano e ao meio ambiente. São, de forma geral, caracterizado por baixa solubilidade em água e alta lipossolubilidade, o que resulta na bioacumulação nos tecidos gordurosos e, conseqüente, biomagnificação.

A resistência natural à degradação biológica e química faz com que os POPs possam ser transportados para lugares distantes de sua fonte emissora, pelo ar e pelas águas, fazendo com que configurem-se em um grupo de substâncias químicas amplamente disseminadas e de particular interesse, em nível global, para a agricultura, a indústria, a saúde pública e o meio ambiente.

Historicamente, a questão dos poluentes orgânicos persistentes, denominados genericamente de organoclorados, mobilizou vários grupos regionais e internacionais. Em nível regional, em 1989, a Conferência Circumpolar Inuit ${ }^{16}$ fez um apelo internacional para o controle da contaminação tóxica do Ártico, colocando em evidência os impactos causados pelos produtos organoclorados e gerando uma série de ações internacionais e regionais. Em 1992, foi formada a "Comissão Mista dos Grandes Lagos", com cientistas dos EUA e Canadá, para tratar da contaminação dos lagos fronteiriços aos dois países, que recomendou a eliminação de todos os usos do cloro como matéria-prima industrial. No mesmo ano, foi formada a "Comissão de Paris”, composta por 13 países da região do Atlântico Nordeste e da União Européia,

15 Texto completo: http://www.pops.int, ou, http://www.senado.gov.br/web/cegraf/diario/

16 Inuit é um grupo de esquimós, população nativa das regiões Árticas do Canadá, Groelândia, Alasca e Sibéria. 
que concordaram em eliminar as descargas de substâncias tóxicas, persistentes e bioacumulativas, particularmente as organocloradas. Em 1993, na Convenção de Barcelona, 21 nações do Mar Mediterrâneo concordaram em eliminar a descarga de substâncias tóxicas, persistentes e bioacumulativas, particularmente os organoclorados.

Devido à capacidade de circulação global dos poluentes persistentes os acordos regionais não se mostraram eficientes para solucionar o problema da contaminação, levando à necessidade de se definir uma ação internacional.

A negociação da Convenção POPs ocorreu durante cinco anos. Em 1995, o Conselho de Administração do PNUMA - Programa das Nações Unidas para o Meio Ambiente aprovou a Decisão 18/32 relacionada aos Poluentes Orgânicos Persistentes e o Programa Interorganizacional para a Gestão Segura das Substâncias Químicas (IOMC), da Organização Mundial da Saúde (OMS), iniciou estudos a respeito dos POPs (POPS, 2004). Em 1997, foi realizada a primeira reunião do Comitê Intergovernamental Negociador para discussão do texto da Convenção, concluído em 2000.

O texto final foi apresentado em maio de 2001, em Estocolmo, Suécia, durante a Conferência Diplomática. Nesta ocasião, mais de 120 países entre eles, o Brasil, assinaram o texto da Convenção comprometendo-se em envidar esforços para sua ratificação, ou seja, transformá-la em instrumento legal em seus respectivos países.

O texto da Convenção compõe-se de um preâmbulo, 30 artigos e seis anexos. Fazem parte do escopo da Convenção doze substâncias químicas: os agrotóxicos Aldrin, Clordano, Mirex, DDT, Dieldrin, Endrin, Heptacloro, Toxafeno; os produtos industriais Hexaclorobenzeno e PCBs; e os produtos de produção "não intencional" Dioxinas e Furanos. Estas substâncias estão distribuídas em três anexos. (A, B e C).

O Anexo A possui duas partes e trata das substâncias que devem ser eliminadas: a Parte I, contém a lista geral das substâncias que devem ser eliminadas - Aldrin, Clordano, Dieldrin, Endrin, Heptacloro, Hexaclorobenzeno (HCB), Mirex, Toxafeno e Bifenilas Policloradas (PCB); a Parte II apresenta as considerações específicas para as bifenilas policloradas. 
O Anexo B apresenta as substâncias que estão sujeitas as restrições, por enquanto só o DDT está nesta lista.

$\mathrm{O} \underline{\text { Anexo } \mathrm{C}}$ é dividido em cinco partes e faz referência às substâncias de produção não intencional, ou seja, formados e liberados não intencionalmente por fontes antropogênicas - Dioxinas (PCDD), Furanos (PCDF), Hexaclorobenzeno (HCB) e Bifenilas Policloradas (PCB).

A Convenção inclui medidas de controle relacionadas a produção, a importação, a exportação, a disposição e o uso das substâncias e determina que os governos promovam as melhores tecnologias e práticas para a sua substituição, bem como previnam o desenvolvimento de novos POPs. Determina, ainda, que os países trabalhem com o objetivo de eliminar (ou restringir, nos casos em que tal meta seja inatingível, pelo menos em curto prazo) o total dos POPs. A Convenção criou, igualmente, um mecanismo para inclusão de outras substâncias que podem vir a ser futuramente classificadas como POPs.

\section{Convenção de Roterdã sobre Procedimento Prévio de Informação de Conformidade $^{17}$}

A Convenção PIC é uma convenção relacionada ao comércio de substâncias químicas que possuem restrições. Ela visa estabelecer mecanismos de controle de movimentos transfronteriços de produtos químicos perigosos à saúde humana e ao meio ambiente, baseado no princípio do consentimento prévio do país importador e na responsabilidade compartilhada no comércio internacional desses produtos (PIC, 2004).

A demanda por esta Convenção deve-se, principalmente, ao rápido aumento da produção e do comércio internacional de substâncias químicas durante os últimos trinta anos, o que contribuiu para o aumento dos riscos decorrentes tanto dos resíduos quanto do uso de substâncias perigosas, dentre elas os agrotóxicos. Isto ocorreu principalmente nos países com infra-estrutura deficiente para o gerenciamento, tornando-os mais vulneráveis aos efeitos adversos dessas substâncias.

17 Texto completo: http://www.pic.int, ou http://www.mma.gov.br/port/sqa/prorisc/doc/textconv.pdf 
A elaboração do texto da convenção teve como referencial o Código de Conduta da FAO, de 1985, relacionado à distribuição e uso de agrotóxicos (FAO, 2002), e as Diretrizes de Londres, de 1987, sobre o Intercâmbio de Informações no Comércio Internacional de Substâncias Químicas (UNEP, 1987).

A Convenção PIC foi assinada na Reunião Diplomática ocorrida em Roterdã, Holanda, em 11 de Setembro de 1998.

No âmbito da Convenção, as substâncias são classificadas em agrotóxicos, formulações severamente restritas e produtos industriais. Atualmente, fazem parte da lista PIC, $38^{18}$ substâncias químicas sendo que 27 foram incluídas durante o processo de negociação e 11 foram definidas no período entre a assinatura da Convenção e a sua entrada em vigor, chamado de período interino. O mecanismo da Convenção denominado Comitê Interino de Revisão Química (CIRQ) foi o responsável pelo trabalho interino, mas agora, com a entrada em vigor da Convenção, estas substâncias serão submetidas aos Países-Parte para apreciação e aprovação.

São 17 os agrotóxicos já oficialmente incluídos: 2,4,5-T; aldrin; captafol; clordano; clodimefor; clorobenzilato; DDT; dieldrin; dinoseb e seus sais; 1,2 dobromoetano; fluoroacetamida; $\mathrm{HCH}$ (mistura de isômeros); heptacloro; hexaclorobenzeno; lindano (gama-HCH); compostos mercuriais e; pentaclorofenol. Além destes, seis agrotóxicos estão listados para inclusão após aprovação: Binapacril; DNOC e seus sais (sais de amônio, potássio e sódio); dicloroetileno; óxido de etileno; monocrotofós e toxafeno.

As formulações severamente restritas já oficialmente incluídas são: metamidofós (formulações com mais que $600 \mathrm{~g}$ do i.a.); metil paration (concentrado emulsionável com $19,5 \%, 40 \%, 50 \%$ do i.a. e poeiras contando $1,5 \%, 2 \%$ e $3 \%$ do i.a.); monocrotofós (formulações líquidas com mais que $600 \mathrm{~g}$ do i.a.); paration (todas as formulações, exceto suspensões encapsuladas) e Fosfamidon (soluções líquidas solúveis com mais que $1000 \mathrm{~g}$ do i.a.). A única formulação severamente restrita, que ainda depende de aprovação, são as formulações que contém a combinação de $7 \%$ ou mais de benomil, $10 \%$ ou mais de Carbofuram e $15 \%$ ou mais de thiram.

18 Informação na URL oficial da Convenção (http://www.pic.int/), julho de 2004. 
As substâncias de uso industrial já incluídas são: bifenilas polibromadas (PBBs); bifenilas policloradas (PCBs); Terfenilas policloradas (PCTs) e o tri (2,3 dibromopropil)fosfato. As substâncias de uso industrial que ainda dependem de aprovação são as relacionadas ao asbesto: actinolita; antofilita; amosita e tremolita.

\subsection{Avaliação de Risco no Contexto das Convenções}

Ambas as convenções fazem referência à necessidade da avaliação dos riscos das substâncias presentes, ou a serem incluídas, no seu escopo. As citações mais diretas desta atividade estão na Convenção de Estocolmo, o que é compreensível, considerando que esta Convenção tem como finalidade restringir substâncias e até eliminar totalmente o seu uso, enquanto a Convenção PIC é focada na criação de um mecanismo de troca de informações sobre restrições existentes nos países, para fins de autorização prévia, ou não, entre parceiros comerciais.

A Convenção POPs, como tem por objetivo final a retirada ou eliminação definitiva de substâncias químicas, procura cercar-se de ferramentas atuais para tomada de decisão.

Para tornar mais clara as abordagens presentes nas Convenções, com relação à avaliação de riscos, foi feito um estudo detalhado sobre as citações relativas à este tema no texto das Convenções.

\section{Convenção POPs}

O Artigo $8^{\circ}$, que detalha todo o procedimento para inclusão de substâncias químicas nos Anexos A, B e C, faz referência clara à avaliação de riscos. Este artigo está diretamente ligado aos Anexos D, E e F, onde estão listadas as informações exigidas para o procedimento.

Segundo o Artigo $8^{\circ}$, a inclusão de uma substância no escopo da Convenção segue um procedimento por etapas [tiers], ou seja, as solicitações vão sendo feitas gradualmente. Primeiramente, o país que solicita a inclusão de uma substância deve enviar ao secretariado as informações solicitadas no Anexo D (identificação, persistência, bioacumulação, potencial de transporte a longa distância, efeitos 
adversos). Caso o "Comitê de Revisão POPs ${ }^{19}$ " considere que as informações sejam suficientes, então são solicitadas as informações do Anexo E (informações exigidas para a elaboração do perfil de risco).

Se o Comitê considerar que as informações são suficientes então é elaborado um "Perfil Preliminar de Risco" e dado um parecer preliminar sobre se a substância deve ou não ser considerada um POPs. Parecer este que será levado para apreciação em uma Conferência das Partes.

Caso o parecer seja afirmativo, ou seja, a substância seja considerada um POPs, todos os Países-Parte devem enviar informações solicitadas no Anexo F (informações sobre considerações sócio-econômicas). Caso seja negativo, o país solicitante possui instâncias para recorrer da decisão e solicitar reavaliação, no âmbito da Conferência das Partes.

Durante esta etapa inicial todos os Países-Parte podem enviar informações relativas aos anexos D, E e F, que também serão consideradas na elaboração do "Perfil Preliminar de Risco".

Após analisar as informações relativas ao Anexo F, o Comitê prepara uma avaliação sobre as medidas de gerenciamento dos riscos, incluindo as medidas de controle da substância e a recomendação quanto ao anexo (A, B ou C) que ela deve ser incluída. A Conferência das Partes dá a palavra final sobre se a substância passa a fazer parte do escopo da Convenção ou não.

Uma vez que o Artigo $8^{\circ}$ é apenas a descrição do procedimento de inclusão de substâncias, só avaliando os Anexos D, E e F de forma mais detalhada é possível identificar as solicitações específicas para a avaliação de risco.

$\mathrm{O}$ Anexo C trata das substâncias não intencionais, tais como as dioxinas e os furanos e a Parte V deste anexo apresenta a "Orientação Geral sobre as Melhores Técnicas Disponíveis e Melhores Práticas Ambientais”, e o $\underline{\text { Item B }}$, desta Parte, diz que:

“B. Melhores técnicas disponíveis

19 O Comitê de Revisão dos Poluentes Orgânicos Persistentes será composto por especialistas em gerenciamento ou avaliação das substâncias químicas designadas por seus respectivos governos, e nomeados com base no critério da distribuição geográfica eqüitativa. 
O conceito de melhores técnicas disponíveis não está dirigido a uma técnica ou tecnologia especifica, mas deve levar em conta as características técnicas da instalação em questão, sua localização geográfica e as condições ambientais locais. As técnicas apropriadas de controle para reduzir liberações das substâncias químicas relacionadas na Parte I são em geral as mesmas. Na determinação das melhores técnicas disponíveis, consideração especial deve ser dada, em geral ou em casos específicos, aos seguintes fatores, tendo em mente os prováveis custos e benefícios de uma medida e as considerações de precaução e prevenção:....

(v) necessidade de evitar ou reduzir a um mínimo o impacto total das liberações para o meio ambiente e os riscos para o mesmo (destaque nosso)"(POPS, 2004).

O referido anexo aplica-se aos poluentes orgânicos persistentes formados e liberados não intencionalmente por fontes antropogênicas, fazendo referência à avaliação de riscos de instalações industriais que apresentem a possibilidade de gerar este tipo de substância, como a incineração (incineradores de resíduos em geral, coincineradores, fornos de cimento), processos industriais de celulose que utilizem cloro e alguns processos térmicos da indústria metalúrgica. As técnicas a serem utilizadas devem ser as melhores disponíveis e para isso devem reduzir ao mínimo o impacto e o risco das liberações.

Para atendimento a este quesito o país deve conhecer as fontes existentes e promover substituição de processos industriais e de técnicas utilizadas, avaliando os riscos das possíveis liberações. O controle das fontes difusas, como queima de lixo a céu aberto e fontes residenciais de combustão, depende da estrutura técnica, social e legal do país.

Com relação ao Anexo D, ele é o primeiro dos três anexos (C, D e F) que listam as informações necessárias para inclusão de substâncias no escopo da Convenção. Neste Anexo são solicitadas, de forma compulsória, informações relacionadas à identificação e, optativamente, informações sobre persistência, bioacumulação, 
potencial de transporte a longa distância e efeitos adversos. Estas informações são pertinentes a identificação do perigo, primeira etapa da avaliação de riscos.

A maioria dos países em desenvolvimento utiliza este mecanismo para tomada de decisão relacionada ao registro e controle de substâncias químicas, mesmo assim em diferentes graus de aprofundamento e de implementação. Esta etapa pode ser considerada de relativa facilidade para ser atendida pelos Países-Parte.

O Anexo E apresenta as informações exigidas para a elaboração do perfil de risco. Nesta etapa, além do país que solicitou a inclusão da substância na Convenção, outros Países-Parte devem enviar informações adicionais. O Comitê revisará a proposta de inclusão e elaborará o perfil de risco, considerando todas as informações recebidas. Com relação à avaliação de riscos, o Anexo E apresenta:

“ANEXO E - Informações Requeridas para o Perfil de Risco

O propósito da revisão (revisão da proposta de inclusão da substância no escopo da Convenção) é avaliar a probabilidade da substância química, como resultado de seu transporte a longa distância no ambiente, provocar efeitos adversos significativos à saúde humana e/ou ao meio ambiente, que venha a justificar uma ação global.

Para este propósito, deve ser desenvolvido um perfil de risco (destaque nosso) mais detalhado, que avalie as informações referidas no Anexo D e inclua, na medida do possível, os seguintes tipos de informações:

a) fontes, incluir conforme o caso:

(i) dados de produção, incluindo quantidade e localização;

(ii) utilização; e

(iii) liberações, tais como descargas, perdas e emissões;

b) avaliação de perigo para o ponto ou pontos terminais de interesse, incluindo o exame de interações toxicológicas envolvendo várias substâncias químicas;

c) destino no ambiente, incluindo dados e informações sobre as propriedades físicas da substância química bem como a sua persistência e 
o modo como estão relacionadas ao transporte da substância no meio ambiente, transferência dentro e entre compartimentos ambientais, degradação e transformação em outras substâncias. Uma determinação do fator de bioconcentração ou fator de bioacumulação, baseado em valores medidos deverá estar disponível, salvo quando os dados de monitoramento sejam julgados satisfatórios;

d) dados de monitoramento;

e) exposição em áreas locais e, em particular, como um resultado de transporte de longa distância no meio ambiente, incluindo informações concernentes a biodisponibilidade;

f) avaliações ou perfis de risco (destaque nosso), informações de rotulagem e classificações de perigo, nacionais e internacionais, quando disponível; e,

g) situação da substância química relativa a outras convenções internacionais." (POPS, 2004).

Seguindo o procedimento gradual de conhecimento da substância, a etapa tratada no Anexo E é mais complexa que a do Anexo D. Para que um país envie as informações solicitadas neste anexo deve possuir um mecanismo de avaliação de riscos de substâncias químicas implementado. Algumas informações são relativamente simples, como dados de produção, utilização e, até, avaliação do perigo. Mas, para atender às solicitações quanto às emissões, as perdas, os dados de monitoramento, as informações sobre exposição e o perfil de risco, o país já deve ter realizado previamente avaliações detalhadas das substâncias.

Como já citado, as primeiras etapas da avaliação de riscos é a identificação do perigo e a avaliação da dose-resposta, o que permite avaliar os efeitos e, juntamente com a avaliação da exposição, caracterizar os riscos. As informações do Anexo E devem permitir ao Comitê caracterizar o risco da substância, por isso as informações são mais sofisticadas e específicas. 
O Anexo $F$ trata das informações sobre considerações socioeconômicas, consideradas complementares para a decisão final sobre inclusão no escopo da Convenção. Os Itens $\underline{a}, \underline{b}$ e g são os que fazem referências a avaliação de riscos.

“ANEXO F - Informações Sobre Considerações Sócio-econômicas

Deve ser realizada uma avaliação relativa às medidas de controle possíveis para substâncias químicas em exame para inclusão na presente Convenção, para toda a faixa de opções, incluindo o manejo e a eliminação. Para este propósito, devem ser fornecidas informações relevantes relacionadas às considerações socioeconômicas associadas às possíveis medidas de controle de modo a permitir que a Conferência das Partes possa tomar decisões. Tais informações devem refletir devidamente as diferentes capacidades e condições entre as Partes e devem incluir consideração sobre os itens da lista indicativa a seguir:

a) eficácia e eficiência de possíveis medidas de controle em atender as metas de redução de risco (destaque nosso):

(i) viabilidade técnica, e

(ii) custos, incluindo custos ambientais e de saúde;

b) alternativas (produtos e processos):

(i) viabilidade técnica;

(ii) custos, incluindo custos ambientais e de saúde;

(iii) eficácia,

(iv) risco (destaque nosso);

(v) disponibilidade; e

(vi) acessibilidade;

g) quaisquer ações de controle nacionais ou regionais tomadas, incluindo informações sobre as alternativas, e outras informações relevantes de gestão de risco". (POPS, 2004). 
Vale destacar que, em qualquer processo de inclusão de substâncias no escopo da Convenção, todos os Países-Parte serão solicitados a enviar informações relativas ao Anexo F.

\section{Convenção PIC}

A Convenção PIC, por tratar do comércio internacional, não exige o envio de informações tão detalhadas como na Convenção POPs. Na maioria das vezes é solicitado apenas o envio de resultados de decisões já tomadas em nível nacional, decorrentes de regulamentos legais nacionais.

Os itens 2 e 3, do Artigo 13 da Convenção, que trata das informações que devem acompanhar as substâncias exportadas, dizem que:

"2. Sem prejuízo de quaisquer exigências da Parte importadora, cada Parte exigirá que tanto as substâncias químicas relacionadas no Anexo III $^{20}$, quanto as substâncias químicas proibidas ou seriamente restritas em seu território, sejam, quando exportados, sujeitos a critérios de rotulagem que garantam uma disponibilidade adequada de informações sobre riscos e/ou perigos para a saúde humana ou ao meio ambiente (destaque nosso), levando em consideração normas internacionais relevantes.

3. Sem prejuízo de quaisquer exigências da Parte importadora, cada Parte poderá exigir que as substâncias químicas sujeitos às exigências de rotulagem de saúde ou ambiental em seu território sejam, quando exportados, sujeitos a exigências de rotulagem que assegurem uma disponibilidade adequada de informações sobre riscos e/ou perigos para a saúde humana ou o meio ambiente (destaque nosso), levando em consideração normas internacionais relevantes (PIC, 2004).”

Neste sentido, os países que pleitearem exportar produtos da Lista PIC, ou substâncias que estejam restritas em seu território, deverão desenvolver rótulos explicativos sobre os riscos e/ou perigos da substância. Esta atividade é relativamente simples, uma vez que já existem muitos exemplos que os países podem 
reproduzir. Sugerem a utilização de pictogramas (figuras) que possam ser reconhecidos em qualquer país.

Outro ponto que faz referência ao risco é o Anexo I, que apresenta as informações necessárias para as notificações solicitadas no Artigo 5 (que trata dos procedimentos que os países devem atender para notificar à Convenção, substâncias químicas proibidas ou severamente restritas em seu território). Este anexo cita que os países devem enviar a ação reguladora final (norma legal de restrição ou proibição), incluindo:

“a) Informações específicas sobre a ação reguladora final:

(vi) Resumo dos perigos e riscos apresentados pela substância química à saúde humana, inclusive à saúde de consumidores e trabalhadores, ou ao meio ambiente (destaque nosso) e o efeito esperado da ação reguladora final (PIC, 2004)".

A maioria dos produtos proibidos ou sob restrição nos países em desenvolvimento foram assim considerados a partir de alertas internacionais sobre produtos antigos, e portanto, não possuem uma justificativa técnica baseada no risco da substância. Por isso, os regulamentos legais são redigidos a partir de estudos sobre o perigo da substância.

A solicitação de um estudo sobre o efeito esperado do regulamento legal, faz parte da etapa de avaliação do gerenciamento, e não é um procedimento muito comum na maioria dos países em desenvolvimento.

Quanto ao Anexo II, ele apresenta os critérios para a inclusão de substâncias químicas proibidas ou severamente restritas no Anexo III (Lista PIC). Neste sentido, define que o Comitê responsável pela avaliação da documentação encaminhada pelo país que está solicitando a inclusão de uma substância na Lista PIC deverá:

“b) Estabelecer que a ação reguladora final foi adotada como resultado de uma avaliação de riscos (destaque nosso). Essa avaliação deverá basear-se num exame de dados científicos no contexto das condições que 
prevalecem na Parte em questão. Para esse fim, a documentação fornecida deverá demonstrar que:

(i) Os dados foram gerados em conformidade com métodos cientificamente reconhecidos;

(ii) Os exames dos dados foram realizados e documentados em conformidade com princípios e procedimentos científicos amplamente reconhecidos;

(iii) A ação reguladora final baseou-se numa avaliação de risco que envolveu as condições que prevalecem na Parte que adotou a ação;

c) Considerar se a ação reguladora final fornece uma base suficientemente ampla para justificar a inclusão da substância química no Anexo III, levando em consideração:

(i) Se a ação reguladora final efetivamente reduziu os riscos ou tinha a finalidade de reduzir significativamente os riscos para a saúde humana ou para o meio ambiente (destaque nosso) da Parte que apresentou a notificação (PIC, 2004)”.

Novamente, um país só poderá solicitar a inclusão de uma substância na Lista PIC caso ele tenha proibido ou restringido a partir da avaliação de risco, prejudicando a efetiva participação dos países que não tem este procedimento implementado.

A Parte 2 do Anexo IV, apresenta as informações e critérios que devem ser coletadas pelo Secretariado, para fins de tomada de decisão com relação à inclusão de formulações de agrotóxicos severamente perigosas no Anexo III (Lista PIC). Dentre outras, cita:

"Parte 2. Informações a serem coletadas pelo Secretariado.

a) As propriedades físico-químicas, toxicológicas e ecotoxicológicas da formulação; 
e) Avaliações de riscos (destaque nosso) e/ou periculosidade, se disponíveis (PIC, 2004)".

Deste modo, para que um país possa participar de forma ativa das decisões sobre a inclusão de substâncias no escopo da Convenção PIC, deve procurar estruturar-se para que as decisões a respeito das restrições ou proibições de substâncias químicas sejam feitas a partir de estudos mais aprimorados, inclusive com estudos sobre o impacto esperado do regulamento legal. 


\section{CONCLUSÕES}

A indústria química brasileira possui um papel significativo no desenvolvimento nacional, representando em torno de 3\% do PIB total do País. Apresentou, em 2003, um faturamento líquido da ordem de US\$ 45,3 bilhões, colocando o Brasil dentre os nove maiores produtores do mundo.

O setor industrial químico define com uma das vulnerabilidades desta indústria as alterações de cunho ecológico-ambiental promovidas pelo governo. Neste contexto a preocupação com a poluição industrial e a conservação do meio ambiente, que podem repercutir em restrições ou banimentos de determinados produtos químicos, tende a ser vista como um empecilho ao desenvolvimento, o que repercute diretamente sobre o gerenciamento das substâncias químicas identificado no País.

No contexto atual, de acelerado desenvolvimento e globalização de todos os aspectos das atividades produtivas, os países utilizam várias estratégias para promover o desenvolvimento e assegurar o bem estar da sociedade presente e futura.

A discussão sobre as políticas que um país adota para gerenciar substâncias químicas deve ser encarada como um fato que propicia tanto o aperfeiçoamento destas estratégias como a identificação de novos objetivos, capacitando o país a enfrentar os desafios da sociedade contemporânea, entre eles, os riscos à saúde de sua população.

Caso os países não promovam este tipo de discussão, estarão fadados a ter que enfrentar os novos desafios utilizando mecanismos anacrônicos ou estratégias que não serão capazes de promover o crescimento do país tendo como referência a promoção de uma sociedade ambientalmente e ecologicamente equilibrada e saudável.

\section{Agenda}

A inclusão de um tema na agenda governamental é o primeiro passo para se formular uma política publica, uma vez que gera discussão e propicia a participação ampla para a formulação da política. 
No Brasil, a formulação das políticas publicas sobre substâncias químicas não faz parte da agenda governamental. A prioridade dada a questão, depende de fatos pontuais, como acidentes, ou pressão decorrente de demandas internacionais ou dos raros grupos nacionais mobilizados. Conseqüentemente os instrumentos legais elaborados são altamente específicos.

Em decorrência deste cenário, os regulamentos existentes para o gerenciamento das substâncias químicas caracterizam-se por serem baseados na "regulação por processo", ou seja, um sistema descentralizado de instrumentos e práticas, sem uma pauta de ação definida. Por causa disso, os processos de gerenciamento existentes são paralelos, desde a fase de planejamento até a de execução.

\section{Formulação das políticas}

Como, no Brasil, o Estado é o principal responsável pela definição dos parâmetros de proteção, as instituições federais, no intuito de atender a esta demanda, atuam de forma independente, de acordo com suas competências, por meio da elaboração de normas legais para os assuntos sob sua responsabilidade.

No caso de setores que envolvem assuntos diversos como economia, meio ambiente e saúde pública, como é o setor das substâncias químicas, é natural que surjam conflitos de interesse e falta de clareza quanto às competências institucionais. Neste contexto, apesar da descentralização da atuação ser benéfica, por propiciar a atuação dos diferentes atores, ela enfraquece a atuação governamental e permite que os interesses da indústria química, um ator não-governamental mobilizado, de forte poder econômico e diretamente afetado pelas políticas formuladas, sejam determinantes na etapa de formulação das políticas públicas.

No Brasil, são vários os exemplos que caracterizam a importância da política econômica de desenvolvimento do país na definição das prioridades nacionais. Estes exemplos vão desde oferecimento de incentivos econômicos para a implantação de industrias químicas, principalmente na época das duas Grandes Guerras, até estímulo ao uso de agrotóxicos na agricultura, como ocorreu na década de 1970 por ocasião do PNDA. 
Resulta que, a atuação unilateral, da maioria das instituições envolvidas no gerenciamento de substâncias químicas, tem gerado uma legislação fragmentada e implementada sob baixo grau de coordenação. As estruturas de gerenciamento são caracterizadas pela atuação sobre substâncias químicas individualizadas, gerenciadas de forma tradicional, ou seja, individualizando os riscos e atuando por meio da fiscalização de padrões de emissão ou, simplesmente, da proibição.

Apesar de, como citado, o sistema de regulação ser descentralizado, o mecanismo de gerenciamento utilizado é do tipo "comando e controle", característico de políticas públicas centralizadas.

Muitos estudos apontam que os riscos na atual sociedade são sistêmicos e globalizados, e para gerenciá-los são necessárias modelos de regulação que extrapolem o mecanismo de "comando e controle" de fontes pontuais e individuais de riscos.

É necessário que os problemas relacionados a substâncias químicas sejam contextualizados na forma mais real possível, bem como os atores envolvidos neste contexto sejam identificados, para que, assim, seja possível discutir de forma ampla o gerenciamento das múltiplas fontes e múltiplos meios. A estrutura de gerenciamento baseada em mecanismos de comando e controle, resulta em um farto arcabouço legal, mas não garante que a sociedade esteja sendo beneficiada, pois depende fundamentalmente da eficiência do Estado em exercer seu papel de fiscalizador.

Para que seja possível otimizar políticas existentes, e realizar inferências mais reais sobre o grau de impacto das substâncias químicas perigosas no país, é necessário um processo de organização nas etapas de formulação das políticas e de resgate dos resultados oriundos do controle realizado. Além disso, a integração institucional, em nível governamental, permitirá identificar e atender diferentes interesses da sociedade e formular políticas com maior possibilidade de sucesso na sua implementação.

O Brasil possui experiências positivas de atuação integrada no gerenciamento de substâncias químicas. Dentre elas destaca-se o CONAMA, que já elaborou diversas 
resoluções intersetoriais abordando diferentes substâncias químicas e, a atuação do Grupo tripartite decorrente do "Acordo do Benzeno", que já obteve importantes vitórias para a redução dos riscos decorrentes do manuseio desta substância.

Além destas, a CONASQ, comissão multi-setorial presidida pelo Ministério do Meio Ambiente, por englobar diferentes atores para discussão de temas atuais e prioritários, definidos pelos próprios participantes, possui alto potencial para gerar políticas de gerenciamento integradas. $O$ fato desta Comissão não ter como finalidade gerar mecanismos legais imediatos, mas sim discutir sobre temas que podem levar à elaboração de políticas públicas, é um exercício promissor para o gerenciamento adequado das substâncias químicas.

\section{Implementação das políticas}

Como a formulação das políticas sobre substâncias químicas é impulsionada por eventos momentaneamente mobilizadores de alguns atores, não existe preocupação com relação à existência ou não de estrutura para sua implementação.

A não discussão sobre a necessidade real da política, sobre os recursos necessários, a análise do custo-benefício da implementação e do custo social envolvido, são fatores que interferem negativamente na implementação integral do arcabouço legal existente, e cria uma lacuna fatal entre a formulação e a implementação.

O arcabouço legal brasileiro é rico em normas, na maioria das vezes consideradas bastante atuais. Entretanto, o grau de transformação destas normas em eventos concretos, ou seja, de implementação das boas intenções do Estado para a geração de benefícios reais para a sociedade, ainda é desconhecido.

\section{Avaliação das políticas}

Tradicionalmente esta etapa não é valorizada no Brasil. A falta de dados oficiais e o reduzido número de resultados de investigações científicas relacionadas às substâncias químicas, dificultam as tentativas de análise da qualidade do meio ambiente e, conseqüentemente, da eficiência das políticas existentes. 
Existem lacunas significativas no sistema de acesso à literatura e bases de dados sobre a gestão de substâncias químicas em nível nacional. Na maioria das vezes, a disseminação dessas informações é viabilizada apenas com base na boa vontade e interesse voluntário de profissionais que atuam nas instituições públicas e, principalmente, instituições privadas envolvidas com o tema, restringindo sobremaneira o acesso.

Para o gerenciamento adequado de substâncias químicas é crucial a existência de informações. A não sistematização dos dados existentes e a falta de programas de monitoramento permanentes, que seriam mecanismo de feed-back das políticas, praticamente inexistem nas instituições responsáveis pelo gerenciamento das substâncias químicas, o que inviabiliza a avaliação das políticas propostas.

\section{Avaliação de Riscos}

A avaliação de riscos é uma das etapas do gerenciamento de riscos e é viabilizada por meio da utilização integrada dos princípios básicos de toxicologia e ecotoxicologia, necessários para o entendimento, quantificação e qualificação da ação de compostos químicos potencialmente perigosos.

Considerando que a avaliação de riscos dá a base para o desenvolvimento dos princípios e recomendações para estabelecer prioridades na regulamentação e controle do uso seguro de uma vasta classe de produtos químicos, ela é o referencial mais adequados para o gerenciamento das substâncias químicas.

Neste contexto, a avaliação de riscos é a base científica que auxilia na tomada de decisão sobre os procedimentos de gerenciamento das substâncias químicas, ou seja, de todas as atividades relacionadas ao controle de substâncias químicas desenvolvidas pelo governo, propiciando a formulação de políticas de redução de riscos mais eficientes e consistentes.

Não existe uma metodologia única para avaliar os riscos das substâncias químicas, mas existem tentativas para harmonizar procedimentos em nível internacional. A escolha sobre a melhor metodologia para avaliar os riscos depende essencialmente do 
grau de implementação dos sistemas de controle de substâncias químicas no país, incluindo a disponibilidade de dados.

Avaliar riscos é uma atividade complexa que envolve esforço multidisciplinar para organizar e analisar informações, demandando a participação de diferentes atores. Mas, a despeito da complexidade para o desenvolvimento e aplicação de metodologias de avaliação de riscos, esta ferramenta é indispensável para o processo de tomada de decisão relacionada à saúde humana.

No Brasil, apesar da descentralização das atividades de gerenciamento e controle das substâncias químicas gerarem problemas de coordenação, por estarem divididas entre as mais diversas áreas do Poder Público, ela é fundamental para a implementação da avaliação de riscos por propiciar a participação de diferentes atores.

O que se observa é que as políticas e instrumentos legais existentes ainda não incorporaram efetivamente o conceito de risco, e não existe preocupação com a consolidação e atualização das informações necessárias para a fundamentação de decisões baseadas em risco. Estas informações estão disseminadas, e não sistematizadas, nas várias instituições do setor público brasileiro voltado para o gerenciamento de substâncias químicas.

Além disso, de forma geral não existe preocupação com a distinção entre os conceitos de risco e perigo nas normas legais. O conceito científico de risco, e a complexidade das questões relacionadas à este conceito, é ignorada na grande maioria nos documentos legais voltados para o gerenciamento de substâncias químicas no Brasil.

$\mathrm{Na}$ maioria das vezes, o termo risco está se referindo ao "crime de perigo", para o qual não é necessária a ocorrência do dano, mas apenas a comprovação da possibilidade de dano para a saúde das pessoas (MACHADO, 1998; NARDOCCI, 1999).

Recentemente o conceito científico de risco passou a ser considerada no arcabouço legal brasileiro, haja vista as citações na Lei de Crimes Ambientais (Lei 9.605/98) e no Decreto sobre agrotóxicos (Decreto 4.074/02). Mas, não existem orientações sobre os princípios que os avaliadores de risco devem seguir para interpretar e julgar 
os dados, os quais são a única maneira de garantir a integridade do processo de avaliação de risco.

As orientações existentes se restringem a padrões, decorrentes do gerenciamento baseado em mecanismos de comando e controle, com a atenção voltada para o refinamento de estimativas de exposição a uma única fonte, o que não é condizente com os riscos que se corre na sociedade atual.

\subsection{Agrotóxicos}

Os principais atores envolvidos no gerenciamento dos agrotóxicos, em nível governamental federal, são os Ministérios da Saúde, do Meio Ambiente e da Agricultura.

De 1924, quando está registrado o primeiro documento legal identificado, até 1989, vários textos legais abordaram a questão dos agrotóxicos, mas nunca de forma específica como foi feito na Lei 7.802/89, um divisor de águas no processo de gerenciamento destas substâncias.

A Lei 7.802/89 foi uma inovação e impôs ao setor executivo do Poder Público um mecanismo altamente complexo, onde o consenso entre os três órgãos federais é o pré-requisito para a aprovação do registro de um produto. Este é o trâmite adequado para tratar o tema, que está na interface entre a produção, meio ambiente e saúde humana, envolvendo o setor público e o privado.

Entretanto, é percebido que a implementação do mecanismo integrado de gerenciamento ainda não foi totalmente internalizado pelas instituições federais, acostumadas a decisões unilaterais.

A legislação para o gerenciamento dos agrotóxicos, proposta em 1989, apresenta um exemplo importante do descompasso existente no País entre a formulação de uma política e a sua efetiva implementação. Como exemplo cita-se o fato de que, apesar da legislação prever a reavaliação e renovação dos registros dos produtos que estavam no mercado antes da Lei 7.802/89, a capacidade estrutural do Estado não pôde suportar tal tarefa e, após tentativas de ajustes, teve que ser suspensa, permitindo que produtos antigos permanecessem no mercado sem a devida avaliação pelo trâmite interministerial. 
A não previsão de que o Estado necessitaria de uma estrutura forte o suficiente para arcar com tal tarefa permitiu este fato, considerado um retrocesso do ponto de vista da segurança no trabalho, saúde pública e meio ambiente, uma vez que retira do Estado a chance de identificar no mercado produtos altamente tóxicos que necessitam de ser restringidos ou proibidos.

Foi identificado que vários ministérios atuam isoladamente no gerenciamento dos agrotóxicos, o que faz com que o controle realizado nas diferentes etapas do ciclo de vida do produto não seja integrado, o dificultando o feed back sobre as políticas implementadas pelos órgãos executores.

Apesar de ser reconhecida a necessidade dos órgãos federais de publicarem regulamentos técnicos específicos de sua área, destaca-se o fato de que praticamente inexistem instrumentos legais publicados de forma conjunta pelos três órgãos, ou seja, de cunho integrado, o que é um indicador da falta de integração entre os setores. No período de 1934 a 2003 foram identificados mais de 55 textos legais sobre o tema, mas apenas uma lei, oito decretos, uma portaria e uma instrução normativa possuem a característica de ter sido redigida por grupos que envolviam mais de um setor interessado. Destacando que os oito decretos foram alterações do Decreto Regulamentador $n^{\circ}$ 98.816, após 1990 .

A legislação atualmente em vigor possui como mecanismo de integração, o Comitê Técnico de Assessoramento de Agrotóxicos - CTA. Apesar desta ser a principal instância de definição dos rumos do gerenciamento dos agrotóxicos no país, ela vem atuando essencialmente para aprovação de usos emergenciais de agrotóxicos.

Além da descentralização do gerenciamento, os gestores não possuem o hábito de convocar cientistas e pesquisadores do País para auxiliar na execução de atividades que exigem alta especialização como, por exemplo, a elaboração de uma proposta de implementação da avaliação de risco.

Uma ação neste sentido democratiza a discussão e dá credibilidade científica às ações governamentais. Muitos países desenvolvidos utilizam os comitês científicos, coordenados por associações cientificas de reconhecida competência, com a participação de políticos, setor privado e sociedade civil, como foro de discussão. 
De forma geral, a legislação brasileira de agrotóxicos é extremamente rigorosa e tem como finalidade reduzir os riscos e evitar os efeitos adversos, muitas vezes irreversíveis, à saúde humana e ao meio ambiente. Para o registro são exigidos numerosos testes, que são submetidos a um processo de avaliação com critérios restritivos. Mas são raros os estudos científicos sobre os impactos advindos da implementação da legislação de agrotóxicos.

Apesar da estrutura reguladora sofisticada destinada aos agrotóxicos, os efeitos externos negativos provenientes da produção agropecuária continuam a existir. A aplicação da Lei 7.802/89 não reduziu o número de casos de intoxicações agudas e o mercado de agrotóxicos expandiu-se, o que leva à conclusão de que houve aumento das vendas de produtos de maior toxicidade.

A falta de informação a respeito dos efeitos dos agrotóxicos sobre a saúde humana e o meio ambiente, aliada à desatualização e desorganização destas informações, é um fator que leva à não inclusão do tema na agenda política do País, acarretando aumento do número de intoxicações humanas e contaminações ambientais.

Apesar da legislação atual definir procedimentos para a divulgação de informações, o acesso à estas informações, no formato adequado aos padrões de conhecimento dos diferentes atores envolvidos, ainda é muito restrito. As informações a serem construídas e disseminadas publicamente, para que sejam úteis devem, pelo menos, gerar credibilidade, serem adequadas, de fácil acesso e serem inteligíveis ao público alvo.

A Portaria IBAMA $n^{\circ} 84 / 96$, criou a ficha que deve ser preenchida pelo registrante para fins de divulgação do registro, mas não define de que forma deve ser divulgada. O Decreto 4.074/02 criou o SIA - Sistema de Informações sobre Agrotóxicos, que ainda não redundou em benefícios reais para a sociedade e está se tornando desatualizado devido à falta de estrutura das instituições.

O processo de gerenciamento de agrotóxicos é altamente dependente da estrutura institucional do Estado, para o controle dos produtos na fase pós-registro.

Atualmente existem mais de 1000 produtos formulados registrados com autorização para uso no campo e a comercialização destes agrotóxicos movimenta em torno de 2,5 bilhões de dólares no país. Além do Estado não arrecadar com o comércio dos 
agrotóxicos, uma vez que eles são isentos de Imposto sobre Circulação de Mercadorias (ICMS) desde 1992 (SOBREIRA e ADISSI, 2003), o Estado é responsável pelo gerenciamento dos agrotóxicos após a emissão do registro, o que inclui gastos como controle e reparação de danos decorrentes do uso dos agrotóxicos, tais como assistência médica, laboratórios clínicos e análise para controle dos resíduos.

Um exemplo claro deste fato é a determinação constante da Portaria 84/96, do IBAMA, que define que o Instituto deve manter ações permanentes de fiscalização e realizar o monitoramento ambiental para acompanhar os impactos ambientais regionais e nacionais. Neste caso, cabe à empresa detentora do registro, apenas "cooperar" na atividade de monitoramento, por meio do fornecimento de informações técnicas.

É competência do Poder Público realizar o controle de todas as formas de poluição, entretanto assumir para si a atividade de monitoramento ambiental, deixando para as detentoras dos produtos apenas a atividade de "cooperação", não é uma divisão eqüitativa dos custos e benefícios. É reconhecida a complexidade envolvida na atividade de monitoramento que, além de ser de alto custo, exige, no mínimo, equipe multidisciplinar em permanente aprimoramento e laboratórios equipados, o que infelizmente ainda não é a realidade das nossas instituições públicas.

Outro exemplo, também na legislação do órgão ambiental, é a citação de que a avaliação de riscos ambiental deve ser realizada quando o IBAMA "identificar a necessidade". Esta consideração coloca sobre o Instituto a responsabilidade de identificar riscos em produtos antigos que já receberam o registro há alguns anos, estão sendo comercializados normalmente e já possuem um mercado definido e dependente. Devido à falta de estrutura para tal atividade, a não ser que ocorra algum evento negativo adverso, que gere mobilização de atores, a possibilidade de identificação, neste sentido, é bastante remota.

Num sistema onde o gerenciamento é baseado em mecanismos de comando e controle, em que a capacidade institucional do país define o grau de implementação das atividades, os gestores devem voltar-se para um posicionamento focado na maior restrição na entrada do processo, ou seja, no momento de registro. Nesta ocasião é 
possível, com a contextualização do problema e em um ambiente de integração interinstitucional, prever e avaliar as fontes de riscos da etapa pós-registro e gerenciar de forma preventiva.

Uma das maiores falhas do gerenciamento de agrotóxicos, atualmente em execução, é a existência de um sistema de avaliação ambiental e de saúde humana institucionalmente desintegrados, mas que, entretanto, utilizam parâmetros comuns para tomada de decisão. Este fato tem sua origem na necessidade de se definir setores de atuação institucional.

Todos os procedimentos previstos para avaliação de agrotóxicos deixam clara que a visão dos gestores é a de que a avaliação à saúde humana é uma atividade isolada da avaliação ambiental. Entretanto, conforme apresentado neste trabalho, esta posição é equivocada, pois se trata de um mesmo processo. O gerenciamento adequado dos agrotóxicos, independentemente se o referencial é risco ou perigo, deve abordar uma visão coordenada de, pelo menos, estes dois aspectos.

O gerenciamento dos agrotóxicos demanda ações descentralizadas, mas é fundamental que exista uma instância de integração que permita a discussão e revisão das políticas de gerenciamento empregadas. Desta forma, ele deve ser executado por equipe multiprofissional, intra e interinstitucional, para que os riscos sejam adequadamente identificados e o gerenciamento tenha como base o contexto real do problema, sendo implementado de forma fundamentada e coerente.

Apesar de existirem normas legais possibilitando o uso da avaliação de riscos, não existem relatos sobre ações neste sentido, sendo o potencial de perigo o procedimento oficial para tomada de decisão no processo de análise. As considerações sobre risco, quando existem, são pontuais e sem orientação clara sobre a metodologia de avaliação utilizada.

A implementação da avaliação de risco é claramente definida no Artigo 95 do Decreto 4.074/2002. Entretanto, como a atividade não é executada, este ponto pode ser caracterizado como um "fato político", ou seja, um fato que causa impacto, mas não garante a concretização da ação. A simples menção da avaliação de riscos em um instrumento legal transmite a intenção política de implementar o procedimento, dando poder para negociação em diversas instâncias, principalmente a internacional. 
Ou seja, o sistema federal de registro de agrotóxicos, que sempre utilizou o "potencial de perigo" como referencial para tomada de decisão, publicou uma legislação (Decreto $\mathrm{n}^{\circ}$ 4.074/2002) reconhecendo a necessidade de inserção da avaliação de riscos de agrotóxicos, mas ainda não inseriu parâmetros sobre riscos nas suas decisões.

Como já citado, a proliferação de tratados, declarações e convenções internacionais exercem forte influência sobre a definição das prioridades em nível nacional. Neste contexto, devido ao estado latente de implementação da avaliação de riscos de agrotóxicos no país, aliado ao fato de que não existe preocupação do Estado em manifestar-se sobre a pendência relacionada ao Artigo 95 do Decreto $n^{\circ}$ 4.074/02, somos levados a concluir que a implantação deste procedimento, para fins de tomada de decisão, é essencialmente uma demanda oriunda dos agentes do executivo, provavelmente pressionados pelos regulamentos e instrumentos internacionais ou por exigências de mercado.

O Decreto 4.074/2002 é considerado inovador e atual, mas ele não foi acompanhado por uma estruturação institucional condizente com as necessidades para sua completa implementação e, decorridos mais de dois anos da publicação ele ainda está em processo de implementação da maioria dos procedimentos previstos no seu escopo. A avaliação de riscos é um exemplo claro desta falha, uma vez que, apesar do País possuir infra-estrutura legal para implementar esta ferramenta de análise, mais uma vez a estrutura administrativa não acompanhou a evolução proposta na lei.

\subsection{Implementação das Convenções no Brasil}

A capacidade para implementar procedimentos operacionais, previstos nas Convenções Internacionais, tem sido uma preocupação de praticamente todos os países do globo que ratificam um instrumento legal desta natureza.

O cenário ideal para que a implementação de uma convenção seja bem sucedida deve ser formatado ainda no período de negociação, quando o tema em foco deve ser discutido quanto à sua relevância para o país. 
A discussão sobre a prioridade que o tema ocupa no cenário político, técnico e social contribui para a mobilização em torno do problema facilitando, assim, o processo de implementação.

Entretanto, o que se observa é que os países, por não terem experiências na definição de prioridades, participam da redação de instrumentos internacionais sem ter noção do impacto que as decisões ali tomadas trarão para o seu país, colocando em xeque a futura implementação. Com relação ao Brasil esta questão não é diferente.

As duas Convenções aqui abordadas, POPs e PIC, possuem mecanismos definidos que exigem a implementação de procedimentos de avaliação de riscos de substâncias químicas incluídas, ou a serem incluídas, no seu escopo.

A Convenção POPs exige atividades técnicas mais sofisticadas de avaliação de riscos, do que a Convenção PIC.

Para atender às demandas da Convenção POPs, o Brasil deve definir estratégias individuais de ação para os diferentes POPs - agrotóxicos, produtos químicos industriais e produtos gerados não intencionalmente, o que deve ser precedido por estudos que visem conhecer o estado da arte da questão, partindo da elaboração de inventários e culminando com a definição das estratégias mais adequadas.

Na maioria dos países em desenvolvimento, incluindo o Brasil, a etapa mais bem estabelecida é a de identificação do perigo e, em alguns casos específicos, a avaliação da exposição. Entretanto, as informações utilizadas para realizar a etapa de avaliação de perigo não são suficientemente convincentes para subsidiar uma proposta de inclusão de uma substância no escopo da Convenção POPs. Além disso, o fato do país não ter estudos aprimorados sobre as substâncias, impedirá o questionamento quanto à inclusão de uma substância proposta por outro país.

Além deste ponto, o país deve incrementar o desenvolvimento de estudos de laboratório, para gerar informações sobre o comportamento de substâncias POPs e, implementar programas de monitoramento, para gerar dados e informações que possam subsidiar futuras decisões do país.

Para atendimento às demandas da Convenção POPs é necessário, dentre outros fatores, o desenvolvimento de estudos epidemiológicos, métodos experimentais de 
laboratório, programas de monitoramento e treinamento para aplicação de métodos de avaliação de risco que possam produzir resultados passíveis de comparação em nível internacional.

A aplicação das determinações do Anexo $C$, que trata das substâncias não intencionais, como as dioxinas e furanos, exige do país, no mínimo, a utilização da avaliação de risco para aprovação de empreendimentos industriais, e o inventário das fontes já existentes relacionadas às substâncias do Anexo $\mathrm{C}$, seguido da implementação de medidas de redução de risco.

No Brasil, para processos a serem instalados, os procedimentos seriam relativamente simples, pois na etapa de licenciamento de atividades industriais, que fica a cargo do setor ambiental, já é feita a análise de risco dos empreendimentos, o que permite conhecer antecipadamente a liberação devida à tecnologia utilizada, possibilitando a atuação preventiva.

No caso de fontes existentes, a situação já é mais complexa, pois é necessário, além de identificar estas fontes, conhecer suas características e o local onde estão instaladas, com a finalidade de serem inventariadas, terem seu risco avaliado e as alterações necessárias propostas e realizadas.

Para o Brasil atender às determinações do Anexo E, que trata do perfil de risco, é necessário que sejam implementados procedimentos de avaliação de riscos de substâncias em nível nacional, e que sejam fomentados a geração de dados, principalmente por meio de programas de monitoramento bem estabelecidos.

Atender ao Anexo F, que aborda as informações sócio-econômicas necessárias, requer do país estudos sofisticados sobre o impacto da utilização ou não de determinada substância. Os países que utilizam a análise "custo-beneficio" para a aprovação de substâncias antes da entrada no mercado, provavelmente estão estruturados para elaborar estes estudos, principalmente por meio de treinamento técnico e desenvolvimento e implementação de novas metodologias, por exemplo. Mas, a maioria dos países em desenvolvimento, cujo referencial para aprovação é o potencial de perigo, terão dificuldades para gerar este tipo de informação. Desta forma a apresentação deste tipo de informação ficará restrita a poucos países. 
De forma geral, tanto as solicitações relativas às substâncias já aprovadas pela Convenção (Anexo A, B e C) quanto as solicitações necessárias para inclusão de uma substância no escopo da Convenção POPs (Anexo D, E e F), tem como objetivo compilar as informações existentes com relação aos aspectos toxicológicos, ecotoxicológicos, econômicos e sociais.

Neste sentido, para o Brasil participar ativamente das decisões da Convenção POPs deverá, no mínimo, investir no treinamento de recursos humanos no campo da segurança química e no aprimoramento da integração entre as instituições detentoras de informações sobre substâncias POPs.

Com relação à Convenção PIC, ela não solicita diretamente a execução de estudos sofisticados de avaliação de riscos, mas, na maioria das vezes, solicita informações sobre os critérios que foram utilizados para fundamentar a decisão sobre restrições de substâncias no país. As solicitações não são tão diretas quanto à Convenção de Estocolmo, e referem-se, em sua maioria, à solicitação de informações que subsidiaram decisões legais.

As solicitações relacionadas a risco, citadas na Convenção PIC, tratam da necessidade de rotulagem com informações sobre os riscos e/ou perigos da substância (Artigo 13); solicitação de envio do resumo dos perigos e riscos apresentados pela substância química à saúde humana e ao meio ambiente, que subsidiam uma ação reguladora utilizada no país (Anexo I); solicitação de que ação reguladora que justifique a inclusão de uma substância química na Convenção tenha como base uma avaliação de riscos. Com relação aos agrotóxicos, é solicitado o envio da avaliação de riscos, caso disponível.

O texto da Convenção deixa transparecer que as decisões baseadas em avaliação de riscos serão consideradas mais relevantes que os estudos baseados apenas no potencial de perigo, que serão aceitos como uma segunda opção.

Conhecer as dificuldades para implementar uma convenção deve preceder a decisão sobre sua ratificação, mas muitas vezes por questões políticas, isto não ocorre.

De forma geral, para a implementação da Convenção PIC, o Brasil necessita, de forma urgente, alterar seu referencial de tomada de decisão migrando paulatinamente 
para a avaliação de risco das substâncias químicas consideradas preocupantes e que poderão vir a sofrer restrição.

Para ambas as Convenções, a coordenação intersetorial e o fortalecimento interinstitucional, deverão ser incrementados.

Especificamente, com relação à avaliação de riscos, o fortalecimento institucional deve ocorrer com a capacitação e treinamento de técnicos do setor público para aplicação de metodologias de avaliação de riscos de substâncias químicas.

\subsection{Recomendações Finais}

- A coordenação intersetorial e o fortalecimento interinstitucional, pontos fracos do gerenciamento de substâncias químicas no Brasil, devem ser incrementados.

- A maioria das pesquisas relacionadas a agrotóxicos está voltada para a geração de dados e informações, em nível laboratorial, o que é fundamental para a fase de identificação dos problemas. Entretanto, as pesquisas científicas sobre os agrotóxicos não devem ficar limitadas a estes ensaios, devendo ser expandidas para as possibilidades políticas, qual sejam, o estudo da eficácia das políticas e a identificação e proposição do aperfeiçoamento dos seus instrumentos, a fim de alcançar de maneira efetiva o gerenciamento ecologicamente equilibrado.

- Como o país possui legislação que permite a implementação da avaliação de riscos de agrotóxicos, previsto no Art. 95 do Decreto Federal 4.074/2002, esta ferramenta deve ser discutida de forma ampla com especialistas, com vista a proposição de alternativas metodológicas passíveis de implementação no País.

- Para a implementação das Convenções PIC e POPs, o enfoque do processo de tomada de decisão deve se ampliar para além da avaliação do perigo. 


\section{REFERÊNCIAS}

[ABIQUIM] Associação Brasileira da Indústria Química. A Indústria química. Disponível em: <URL:http://www.abiquim.org.br>. [2002 Set.18].

[ABIQUIM] Associação Brasileira da Indústria Química. Anuário da Indústria Química Brasileira. São Paulo: ABIQUIM. 2004.

[ABNT] ASSOCIAÇÃO BRASILEIRA DE NORMAS TÉCNICAS. Gerenciador Eletrônico de Normas. Disponível em: <URL: http://www.abntdigital.com.br/>. [2004 Abr.18].

Alves Filho, J.L Uso de agrotóxicos no Brasil: controle social e interesses corporativos. São Paulo: Annablume; FAPESP; 2002.

Amaral e Silva, C.C. Gerenciamento social de risco. São Paulo; 2003 [anotações de aula].

Anderson, E. L.; Hilaire, C.St. The contrast between risk assessment and rules of evidence in the context of international trade disputes: Can the U.S. experience inform the process? Risk Analysis. 2004. 24(2): 449 - 459.

[ANVISA] AGÊNCIA NACIONAL DE VIGILÂNCIA SANITÁRIA. Manual de Procedimentos para Análise Toxicológica de Produtos Agrotóxicos, seus componentes e afins. Disponível em: <URL: http://www.anvisa.gov.br/toxicologia/publica.htm />. [2004 Fev.18].

[ANVISA] AGÊNCIA NACIONAL DE VIGILÂNCIA SANITÁRIA. Seis produtos agrotóxicos suspeitos de provocar reações adversas foram reavaliados. 2002a. Disponível em: <URL: http://www.anvisa.gov.br/divulga/noticias/2002/260702.htm />. [2004 Abr.18].

[ANVISA] AGÊNCIA NACIONAL DE VIGILÂNCIA SANITÁRIA. SIA Sistema de Informações sobre Agrotóxicos. 2002b. Disponível em: <URL: http://www4.anvisa.gov.br/agrosia/asp/default.asp >. [2004 Mai. 13]. 
ANVISA. Agência Nacional de Vigilância Sanitária. Portaria $n^{0}$ 3, de 16 de janeiro de 1992. Ratifica os termos das "diretrizes e orientações referentes à autorização de registros, renovação de registro e extensão de uso de produtos agrotóxicos e afins - $\mathrm{n}^{\circ}$ 1, de 09/12/1991", publicadas no D.O.U. em 13/12/91. Diário Oficial da União. Brasília, 04 de fevereiro de 1992. Disponível em: <URL: http:/elegis.bvs.br/leisref/public/showAct.php?id=560\&word=/>. [2003 Out. 30].

ANVISA. Agência Nacional de Vigilância Sanitária. Resolução $\mathrm{n}^{\mathrm{o}} 5$ de 14 de outubro de 1999a. Suspende a aprovação e a avaliação toxicológica para registro de novas formulações de produtos agrotóxicos com a mistura de princípios ativos considerados potencialmente carcinogênicos. Diário Oficial da União. Brasília, de 18 de outubro de 1999. Disponível em: <URL: http://elegis.bvs.br/leisref/public/showAct.php?id=7876\&word=>>. [2003 Out. 5].

ANVISA. Agência Nacional de Vigilância Sanitária. Resolução $\mathrm{n}^{\circ}$ 6, de 14 de outubro de 1999b. Suspende a aprovação e a avaliação toxicológica para registro de novos produtos técnicose/ou formulações de agrotóxicos à base de Paration Metílico e Metamidofós. Reavalia toxicologicamente os produtos técnicos Paration Metílico e Metamidofós e suasformulações já autorizadas pelo Ministério da Saúde, bem como rever suas monografias. Diário Oficial da União. Brasília, de 18 de outubro de 1999. Disponível em: <URL: http:/elegis.bvs.br/leisref/public/showAct.php?id=7876\&word=>>. [2003 Out. 5].

ANVISA. Agência Nacional de Vigilância Sanitária. Resolução $\mathrm{n}^{\mathrm{o}} 7$, de 14 de outubro de 1999c. Suspende a aprovação e avaliação toxicológica para registro de novas formulações e misturas de produtos técnicos com o princípio ativo Alachlor.

Diário Oficial da União. Brasília, 15 de outubro de 1999 Disponível em: <URL: http://elegis.bvs.br/leisref/public/showAct.php?id=7876\&word=>. [2003 Out. 5].

ANVISA. Agência Nacional de Vigilância Sanitária. Resolução - RDC nº 44, de 10 de maio de 2000a. Altera as Diretrizes e Exigências Referentes a Autorização de Registro de Produtos Agrotóxicos e Afins, $\mathrm{n}^{\circ}$ 1, de 09 de dezembro de 1991, ratificada pela Portaria $n^{\circ} 3$ de 16 de Janeiro de 1992.. Diário Oficial da União. 
Brasília, 11 de maio de 2000. Disponível em: <URL http://elegis.bvs.br/leisref/public/showAct.php?id=1210\&word=>. [2003 Out. 30].

ANVISA. Agência Nacional de Vigilância Sanitária. Resolução RE nº 104 de 17 de agosto de 2000b. Faz avaliação toxicológica de produtos que contenham princípios ativos de uso corrente no País com base em informações científicas reconhecidas. Diário Oficial da União. Brasília, 19 de setembro de 2000. Disponível em: $<U R L$ http://e-legis.bvs.br/leisref/public/search.php>. [2003 Out. 30].

ANVISA. Agência Nacional de Vigilância Sanitária. Resolução - RDC nº 98, de 20 de novembro de 2000c. Publica a atualização das listas de substâncias sujeitas a controle especial (Anexo I) de acordo com o artigo 101 do Regulamento Técnico aprovado pela Portaria SVS/MS n. ${ }^{\circ}$ 344, de 12 de maio de 1998. Diário Oficial da União. Brasília, 22 de novembro de 2000. Disponível em: <URL: http:/elegis.bvs.br/leisref/public/showAct.php?id=13808\&word=>. [2003 Out. 5].

ANVISA. Agência Nacional de Vigilância Sanitária. Portaria Conjunta n. ${ }^{\circ}$ 1, de 25 de outubro de 2001. Procede à reavaliação toxicológica e ambiental dos produtos técnicos e formulados a base de benomil e carbendazim. Diário Oficial da União. Brasília, 26 de outubro de 2001. Disponível em: <URL: http://elegis.bvs.br/leisref/public/showAct.php?id=5946\&word=/>. [2003 Out. 5].

ANVISA. Agência Nacional de Vigilância Sanitária. Resolução RDC nº 135, de 17 de maio de 2002c. Procede à reavaliação toxicológica dos produtos técnicos e formulados à base dos ingredientes ativos Dicofol, Heptacloro, MSMA, Linuron, Captan, Folpet, Clorotalonil, Vinclozolin, Epoxiconazole, Procloraz, Clorpirifós. E institui comissão técnica para proceder à reavaliação procedida. Diário Oficial da União. Brasília, 22 de maio de 2002. Disponível em: http:/elegis.bvs.br/leisref/public/search.php. [2003 out.].

ANVISA. Agência Nacional de Vigilância Sanitária. Resolução RDC no 119 de 19 de maio de 2003. Criar o Programa de Analise de Resíduos de Agrotóxicos em Alimentos - PARA. Diário Oficial da União. Brasília, 22 de maio de 2003. 
Disponível

em:

$<\mathrm{URL}$ :

http://e-

legis.bvs.br/leisref/public/showAct.php?id=7876\&word=>. [2003 Out. 5].

ANVISA. Agência Nacional de Vigilância Sanitária. Resolução RE nº 87, de 26 de abril de 2004. Estabelece o prazo de 120 dias, após a aprovação da ANVISA, para os registrantes de produtos agrotóxicos adequarem as informações nos rótulos e bulas. Diário Oficial da União. Brasília, 27 de abril de 2004. Disponível em: <URL: http://e-legis.bvs.br/leisref/public/search.php/>. [2003 Out. 5].

Augusto, L.G.S.; Branco, A. Política de informação em saúde ambiental. Revista Brasileira de Epidemiologia. 2003. 6(2): 150-157.

Ayres, J.R.C.M. Sobre o risco: para compreender a epidemiologia. São Paulo: Hucitec; 1997.

Barbieri, J.C. Políticas públicas indutoras de inovações tecnológicas ambientalmente saudáveis nas empresas. Revista de Administração Pública. Rio de Janeiro 1997; 31(2):135-152.

Batterman, S.; Kovacs, E. Threshold quantity criteria for risk management programs: recomendations for toxics releases. Journal of Hazardous Materials. 2003; A105:39 - 60 .

Benson. K.J. The interorganizational network as a political economy. In: Karpik, Lucien (ed.) Organization and Environment: theory, issues and reality: Guilford, 1978.

Bernstein, P.L. Desafio aos Deuses: a fascinante história do risco. Rio de Janeiro: Campus; 1997.

Bodar, C.; Bruijn, J.; Vermeire, T.; Van der Zandt, P. Trends in risk assessment of chemicals in the European Union. Human and Ecological Risk Assessment. 2002; 8(7):1825-1843. 
Brasil. Constituição da República Federativa do Brasil. 1988. Disponível em:

<URL: http:// http://www.senado.gov.br/bdtextual/const88/const88.htm/>. [2003 Out. 30].

Brasil. Decreto Executivo $\mathrm{n}^{\mathrm{o}} 16.300$, de 31 de dezembro de 1923. Aprova o regulamento do Departamento Nacional de Saude Pública. Citação em em: <URL: https://legislacao.planalto.gov.br/legislacao.nsf/fraWeb?OpenFrameSet\&Frame=frm Web2\&Src=\%2Flegislacao.nsf\%2FpagInicio\%3FOpenPage\%26AutoFramed/ $\quad>$. [2003 Out. 30].

Brasil. Decreto Federal n 23.629 de 23 de dezembro de 1933. Aprova o regulamento para o embarque e desembarque de inflamáveis, explosivos, corrosivos e produtos agressivos em geral no porto do Rio de Janeiro. Disponível em: <URL: http://www.lei.adv.br/>. [2004 Abr. 30].

Brasil. Decreto Federal $\mathrm{n}^{\mathrm{o}}$ 23.777, de 23 de janeiro de 1934a. Regulariza o lançamento do resíduo industrial das usinas açucareiras nas águas fluviais. Disponível em: <URL: http://www.lei.adv.br/>. [2004 Abr. 30].

Brasil. Decreto Federal n 24.114 , de 12 de abril de 1934b. Aprova o regulamento de defesa sanitária vegetal. Disponível em <URL: https://legislacao.planalto.gov.br/>. [2003 Nov. 25].

Brasil. Decreto Federal no 49.974, de 21 de janeiro de 1961a. Regulamenta, sob a denominação de Código Nacional de Saúde, a Lei $\mathrm{n}^{\mathrm{o}}$ 2.312, de 3 de setembro de 1954, de "Normas Gerais Sobre Defesa e Proteção da Saúde". Disponível em: <URL: http://www.lei.adv.br//>. [2003 Out. 30].

Brasil. Decreto Federal $n^{\circ}$ 50.877, de 29 de junho de 1961b. Dispõe sobre o lançamento de resíduos tóxicos ou oleosos nas águas interiores ou litorâneas do País e dá outras providências. Disponível em: <URL: http://www.lei.adv.br/>. [2003 Out. $30]$. 
Brasil. Decreto Federal no 55.649, de 28 de janeiro de 1965a. Dá Nova Redação ao Regulamento aprovado pelo Decreto $\mathrm{n}^{\mathrm{o}}$ 1.246, de 11 de dezembro de 1936. Disponível em: <URL: http://www.lei.adv.br>. [2003 Out. 30].

Brasil. Decreto Federal no 58.016, de 18 de março de 1966. Regulamenta o disposto na Lei $\mathrm{N}^{\circ} 4.797$, de 20 de outubro de 1965 e dá outras providências. Disponível em: $<$ URL: http://www.lei.adv.br>. [2004 Abr. 4].

Brasil. Decreto Federal $\mathrm{n}^{\circ} 76.389$, de 03 de outubro de 1975b. Dispõe sobre as medidas de prevencão e controle da poluicão industrial, de que trata o Decreto-Lei 1413, de 14 de agosto de 1975, e da outras providencias. Disponível em: <URL: https://legislacao.planalto.gov.br/>. [2003 Nov. 25].

Brasil. Decreto Federal no 83.540, de 04 de junho de 1979. Regulamenta a aplicação da Convenção Internacional sobre Responsabilidade Civil em Danos Causados por Poluição por Óleo, de 1969, e dá outras providências. Diário Oficial da União. Brasília, 05 de junho de 1979. Disponível em: <URL: http://www.lei.adv.br/>. [2003 Out. 30].

Brasil. Decreto Federal n ${ }^{\circ}$ 97.634, de 10 de abril de 1989. Dispõe sobre o controle da producão e da comercializacão de substância que comporta risco para a vida, a qualidade de vida e o meio ambiente, e dá outras providências. Diário Oficial da União. Brasília, 12 de abril de 1989. Disponível em: <URL: https://www.planalto.gov.br/>. [2003 Out. 30].

Brasil. Decreto Federal no 98.816 de 11 de janeiro de 1990a. Regulamenta a Lei $n^{\circ}$ 7.802, de 1989, que dispõe sobre a pesquisa, a experimentação, a produção, a embalagem e rotulagem o transporte, o armazenamento, a comercialização, a propaganda comercial, a utilização, a importação, exportação, o destino final dos resíduos e embalagens, o registro, a classificação, o controle, a inspeção e a físcalização de agrotóxicos, seus componentes e afins, e dá outras providências. Diário Oficial da União. Brasília, 12 de janeiro de 1990. Disponível em: <URL: http://www.presidencia.gov.br/ccivil_03/decreto/Antigos/D98816.htm/>. [2003 Out. 30]. 
Brasil. Decreto Federal n ${ }^{0}$ 99.657, de 26 de outubro de 1990b. Acrescenta artigo e parágrafo único ao Decreto $\mathrm{n}^{\circ}$ 98.816, de 11 de janeiro de 1990, que regulamenta a Lei $\mathrm{n}^{\mathrm{o}}$ 7.802, de 11 de julho de 1989, que dispõe sobre agrotóxicos, seus componentes e afins, e dá outras providências. Diário Oficial da União. Brasília, 29 de outubro de $1990 . \quad$ Disponível em: <URL: http://www.presidencia.gov.br/ccivil_03/decreto/Antigos/D99657.htm />. [2003 Out. 23].

Brasil. Decreto Federal $n^{\circ}$ 991, de 24 de novembro de 1993. Altera o Decreto $n^{\circ}$ 98.816, de 11/01/ 1990, no que dispõe sobre a regulamentação da Lei ${ }^{\circ} 7.802$, de 11/07/ 1989. Diário Oficial da União. Brasília, 25 de novembro de 1993. Disponível em: <URL: http://www.presidencia.gov.br/ccivil_03/decreto/Antigos/D991.htm/ />. [2003 Out. 30].

Brasil. Decreto Federal no 1.253, de 27 de setembro de 1994. Promulga a Convencão número 136, da Organizacão Internacional do Trabalho, sobre a protecão contra os riscos de intoxicacao provocados pelo benzeno, assinada em Genebra, em 30/06/1971. (OIT). DLg 76, de 19/11/1992 - Governo Itamar Franco. Diário Oficial da União. Brasília, 28 de setembro de 1994. Disponível em: <URL: http://www.lei.adv.br/>. [2003 Out. 30].

Brasil. Decreto Federal $\mathrm{n}^{\circ}$ 3.179, de 21 de setembro de 1999. Dispõe sobre a especificação das sanções aplicáveis às condutas e atividades lesivas ao meio ambiente, e dá outras providências. Diário Oficial da União. Brasília, 22 de setembro de $1999 . \quad$ Disponível em: <URL: http://www.presidencia.gov.br/ccivil_03/decreto/D3179.htm//>. [2003 Out. 30].

Brasil. Decreto Federal no 3.550, de 27 de julho de 2000c. Dá nova redação a dispositivos do Decreto no 98.816, de 11/01/1990, que dispõe sobre a pesquisa, a experimentação, a produção, a embalagem e rotulagem, o transporte, $\mathrm{o}$ armazenamento, a comercialização, a propaganda comercial, a utilização, a importação, a exportação, o destino final dos resíduos e embalagens, o registro, a classificação, o controle, a inspeção e a fiscalização de agrotóxicos, seus componentes e afins. Diário Oficial da União. Brasília, 28 de julho de 2000. 
Disponível

em:

$<\mathrm{URL}:$

http://www.presidencia.gov.br/ccivil_03/decreto/D3550.htm/>. [2003 Out. 5].

Brasil. Decreto Federal $n^{\circ} 4.074$, de 4 de Janeiro de 2002a. Regulamenta a Lei no 7.802, de 11/07/1989, que dispõe sobre a pesquisa, a experimentação, a produção, a embalagem e rotulagem, o transporte, o armazenamento, a comercialização, a propaganda comercial, a utilização, a importação, a exportação, o destino final dos resíduos e embalagens, o registro, a classificação, o controle, a inspeção e a fiscalização de agrotóxicos, seus componentes e afins, e dá outras providências. Diário Oficial da União. Brasília, 8 de janeiro de 2002. Disponível em: <URL: http://www.presidencia.gov.br/ccivil_03/decreto/2002/D4074.htm>. [2003 Out. 3].

Brasil. Decreto Legislativo $\mathrm{n}^{\mathrm{o}}$ 197, de 7 de maio de 2004a. Aprova o texto da Convenção sobre Procedimento de Consentimento Prévio Informado para o Comércio Internacional de Certas Substâncias Químicas e Agrotóxicos Perigosos, adotada em 10 de setembro de 1998, na cidade de Roterdã. Diário Oficial da União. Seção I, no 88 pg. 1. Brasília, 07 de maio de 2004. Disponível em: <URL: https://www.senado.gov.br/ />. [2004 jul. 15].

Brasil. Decreto Legislativo $\mathrm{n}^{\mathrm{o}}$ 204, de 7 de maio de 2004b. Aprova o texto da Convenção de Estocolmo sobre Poluentes Orgânicos Persistentes, adotada, naquela cidade, em 22 de maio de 2001. Diário Oficial da União. Seção I, nº 88 pg. 2. Brasília, 10 de maio de 2004. Disponível em: <URL: https://www.senado.gov.br/ />. [2004 jul. 15].

Brasil. Decreto Lei $\mathrm{n}^{\circ} 1.413$, de 14 de agosto de 1975a. Dispõe sobre o controle da poluicão do meio ambiente provocada por atividades industriais. Disponível em: <URL: https://legislacao.planalto.gov.br/legislacao.nsf/>. [2003 Nov. 25].

Brasil. Decreto Lei n ${ }^{\circ} 2.063$, de 06 de outubro de 1983. Dispõe sobre multas a serem aplicadas por infracões a regulamentacão para a execucão do serviço de transporte rodoviário de cargas ou produtos perigosos e dá outras providências. Diário Oficial da União. Brasília, 07 de outubro de 1983. Disponível em: <URL: https://legislacao.planalto.gov.br/legislacao.nsf/>. [2003 Nov. 25]. 
Brasil. Lei Federal n n $^{\text {4.785, de }} 06$ de outubro de 1965b. Dispõe sobre a fiscalizacão do comércio e uso de produtos fitossanitários e dá outras providências. Diário Oficial da União. Brasília, 11 de outubro de 1965. Disponível em: <URL: https://legislacao.planalto.gov.br/legislacao.nsf/>. [2004 abr 26].

Brasil. Lei Federal 4.797 de 20 de outubro de 1965c. Torna obrigatório pelas emprêsas concessionárias de serviços públicos, o emprêgo de madeiras preservadas e dá outras providências. Diário Oficial da União. Brasília, 22 de outubro de 1965. Disponível em: <URL: http://e-legis.bvs.br/leisref/public/showAct.php?id=537/>. [2004 abr 26].

Brasil. Lei Federal no 6.360, de 23 de setembro de 1976. Dispõe sobre a Vigilância Sanitária a que ficam sujeitos os Medicamentos, as Drogas, os Insumos Farmacêuticos e Correlatos, Cosméticos, Saneantes e Outros Produtos, e dá outras Providências. Diário Oficial da União. Brasília, 24 de setembro de 1976. Disponível em: <URL: https://legislacao.planalto.gov.br/legislacao.nsf/>. [2004 abr 26].

Brasil. Lei Federal n 6.514, de 22 de dezembro de 1977. Altera o capítulo V do título II da Consolidação das Leis do Trabalho (CLT - DEC 5.452, de 1943) relativo a segurança e medicina do trabalho, e dá outras providências. Diário Oficial da União. Brasília, 23 de dezembro de 1977. Disponível em: <URL: https://legislacao.planalto.gov.br/>. [2003 Out. 15].

Brasil. Lei Federal $n^{\circ}$ 6.938, de 31 de agosto de 1981. Dispõe sobre a Política Nacional do Meio Ambiente, seus fins e mecanismos de formulação e aplicação, a da outras providências. Diário Oficial da União. Brasília, 02 de setembro de 1981. Disponível em: <URL: https://legislacao.planalto.gov.br/>. [2003 Out. 30].

Brasil. Lei Federal $n^{0} 7.802$, de 11 de Julho de 1989. Dispõe sobre a pesquisa, a experimentação, a produção, a embalagem e rotulagem, o transporte, o armazenamento, a comercialização, a propaganda comercial, a utilização, a importação, a exportação, o destino final dos resíduos e embalagens, o registro, a classificação, o controle, a inspeção e a fiscalização de agrotóxicos, seus componentes e afins, e dá outras providências. Diário Oficial da União. Brasília, 12 
de junho de $1989 . \quad$ Disponível em: <URL: http://www.presidencia.gov.br/ccivil_03/Leis/L7802.htm / />. [2003 Out. 5].

Brasil. Lei Federal $\mathrm{n}^{\circ}$ 9.017, de 30 de março de 1995a. Estabelece normas de controle e fiscalizacão sobre produtos e insumos químicos que possam ser destinados a elaboração da cocaína em suas diversas formas e de outras substâncias entorpecentes ou que determinem dependência física ou psíquica, e altera dispositivos da Lei $n^{0} 7.102$, de 20/06/1983, que dispõe sobre segurança para estabelecimentos financeiros, estabelece normas para constituição e financiamento de empresas particulares que explorem serviços de vigilância e de transporte de valores, e dá outras providências. Diário Oficial da União. Brasília, 31 de março de 1995. Disponível em: <URL: https://www.planalto.gov.br/>. [2003 Out. 30].

Brasil. Lei Federal $n^{\circ}$ 9.055, de $1^{\circ}$ de junho de 1995b. Disciplina a extracão, industrializacão, utilizacão, comercializacão e transporte do Asbesto / Amianto e dos produtos que o contenham, bem como das fibras naturais e artificiais, de qualquer origem, utilizadas para o mesmo fim e da outras providências. Diário Oficial da União. Brasília, 02 de junho de 1995. Disponível em: <URL: https://www.planalto.gov.br/ />. [2003 Out. 5].

Brasil. Lei Federal n 9.294, de 15 de julho de 1996. Dispõe sobre as restrições ao uso e à propaganda de produtos fumígeros, bebidas alcoólicas, medicamentos, terapias e defensivos agrícolas, nos termos do $\S 4^{\circ}$ do art. 220 da Constituição Federal. Diário Oficial da União. Brasília, 17 de julho de 1996. Disponível em: <URL: https://www.planalto.gov.br/ >>. [2003 Out. 23].

Brasil. Lei Federal n 9.605, de 12 de fevereiro de 1998. Dispõe sobre as sanções penais e administrativas derivadas de condutas e atividades lesivas ao meio ambiente, e dá outras providências. Diário Oficial da União. Brasília, 13 de fevereiro de 1998, retificada em 17 de fevereiro de 1998. Disponível em: <URL: http://www.presidencia.gov.br/ccivil_03/Leis/L9605.htm/>. [2003 Out. 5].

Brasil. Lei Federal no 9.782, de 26 de janeiro de 1999. Define o Sistema Nacional de Vigilância Sanitária, cria a Agência Nacional de Vigilância Sanitária, e dá outras 
providências. Diário Oficial da União. Brasília, 27 de janeiro de 1999. Disponível em: <URL: http://e-legis.bvs.br/leisref/public/showAct.php?id=182\&word=/>. [2003 Out. 5].

Brasil. Lei Federal $\mathrm{n}^{\circ}$ 10.167, de 27 de dezembro de 2000d. Altera dispositivos da Lei no 9.294, de 15 de julho de 1996, que dispõe sobre as restrições ao uso e à propaganda de produtos fumígenos, bebidas alcoólicas, medicamentos, terapias e defensivos agrícolas. Mensagem de Veto $\mathrm{n}^{0}$ 2.088. Diário Oficial da União. Brasília, 28 de dezembro de 2000. Disponível em: <URL: https://www.planalto.gov.br/ />. [2003 Out. 5].

Brasil. Lei Federal n ${ }^{\circ}$ 9.974, de 6 de junho de 2000b. Altera a Lei no 7.802, de 11 de julho de 1989, que dispõe sobre a pesquisa, a experimentação, a produção, a embalagem e rotulagem, o transporte, o armazenamento, a comercialização, a propaganda comercial, a utilização, a importação, a exportação, o destino final dos resíduos e embalagens, o registro, a classificação, o controle, a inspeção e a fiscalização de agrotóxicos, seus componentes e afins, e dá outras providências. Diário Oficial da União. Brasília, 7 de junho de 2000. Disponível em: <URL: http://www.presidencia.gov.br/ccivil_03/Leis/L9974.htm>. [2003 Out. 30].

Brasil. Lei Federal $n^{\circ} 10.165$, de 27 de dezembro de 2000a. Altera a Lei $n^{\circ} 6.938$, de 31 de agosto de 1981, que dispõe sobre a Política Nacional do Meio Ambiente, seus fins e mecanismos de formulação e aplicação, e dá outras providências. Diário Oficial da União. Brasília, 28 de dezembro de 2000. Disponível em: <URL: https://www.planalto.gov.br/ />. [2003 Out. 5].

Brasil. Lei Federal $n^{\circ} 10.603$, de 17 de dezembro de 2002c. Dispõe sobre a proteção de informação não divulgada submetida para aprovação da comercialização de produtos e dá outras providências. Diário Oficial da União. Brasília, 18 de dezembro 2002. De Disponível em: <URL: http://www.presidencia.gov.br/ccivil_03/Leis/2002/L10603.htm>. [2003 Out. 3].

Brasil. Ministerio da Agricultura e Reforma Agrária; Ministerio da Saúde; Secretaria do Meio Ambiente. Portaria Conjunta $n^{\circ}$ 86, de 25 de julho de 1991. Constitui a 
Comissão Técnica de Assessoramento para Agrotóxicos. Diário Oficial da União. Brasília, 26 de julho de 1991. Disponível em: <URL: http://www2.ibama.gov.br/>. [2003 Out. 5].

Brasil. Ministério da Agricultura, Pecuária e Abastecimento, Ministério da Saúde, Ministério do Meio Ambiente. Instrução Normativa Interministerial $n^{\circ} 49$ de 20 de agosto de 2002b. a avaliação, para fins de obtenção do registro de produto técnico equivalente, será realizada com observância dos critérios constantes do Anexo.. Diário Oficial da União. Brasília, 21 de agosto de 2002. Disponível em: <URL: http://e-legis.bvs.br/leisref/public/search.php/>. [2003 Nov. 25].

Brilhante, O.M. Gestão e avaliaçao da poluição, impacto e risco na sáude ambiental In: Brilhante, O.M. e Caldas, L.M.A. Coordenadores. Gestão e avaliação de risco em saúde ambiental. Rio de Janeiro: Ed. FIOCRUZ, 1999 - p. 19-73.

Brown, J. V. REACHing for chemical safety - Environews/Spheres of Influence. Environmental Health Perspectives. Nov. 2003; 111(14): A767 - A769.

Bruson, T.L. O fator "higiene ocupacional” dentro da análise do ciclo de vida de um produto: proposta para abordagem. São Paulo; 2001. [Tese de Mestrado Faculdade de Saúde Pública da USP].

Bucci, M.P.D. Políticas públicas e direito administrativo. Revista de Informação Legislativa. Brasília. jan/mar 1997; 34(133):89-98.

Caldas E.D. e Souza, L.C.K. Avaliação de risco crônico da ingestão de resíduos de pesticidas na dieta brasileira. Revista de Saúde Pública. 2000; 34(5): 529-537.

Caldas, L.Q.A. Risco potencial em toxicologia ambiental. In: Brilhante, O.M. e Caldas, L.M.A. Coordenadores. Gestão e avaliação de risco em saúde ambiental. Rio de Janeiro: Ed. FIOCRUZ, 1999 - p. 93-117.

Campos, A. M. M.; Júnior, D.S.S.S.; Ávila, J.P.C. Avaliação de agências reguladoras: uma agenda de desafios para a sociedade brasileira. Revista de Administração Pública. Rio de Janeiro. 2000; 34(5):29-46. 
Carneiro, R. Direito Ambiental: uma abordagem econômica. Rio de Janeiro: Forense; 2001.

[CCE ] Comissão das Comunidades Européias. Livro Branco - Estratégia para a futura política em matéria de substâncias químicas. Disponível em: <URL: http://europa.eu.int/comm/environment/chemicals/0188_pt.pdf >. [2004 mar.18].

[CETESB] Companhia de Tecnologia de Saneamento Ambiental. Emergências Químicas - Tipos de Acidentes - Rodoviários - Legislação Nacional Federal. Disponível em: <URL: http://www.cetesb.sp.gov.br/emergencia/acidentes/rodoviarios/legislacao_federal.asp >. [2004 Abr.23].

Christensen, F.M.; Andersen, O.; Duijm, N.J.; Harremoës, P. Risk terminology - a platform for common understanding and better communication. Journal of Hazardous Materials. 2003; A103: 181- 203.

[CMMAD] Comissão Mundial sobre Meio Ambiente e Desenvolvimento. Nosso futuro comum. Relatório Brundtland. Rio de Janeiro. Fundação Getúlio Vargas. 1988.

[CNUMAD] Conferência das Nações Unidas sobre Meio Ambiente e Desenvolvimento, 1992, Rio de Janeiro. Agenda 21. Brasília. Senado Federal Subsecretaria de Edições Técnicas. 2001. 598 p.

CONAMA. Resolução CONAMA nº 005, de 20 de novembro de 1985. Dispõe sobre o prévio licenciamento por órgão estadual nas atividades de transporte, estocagem e uso do "Pó da China". Diário Oficial da União. Brasília, 22 de novembro de 1985. Disponível em: <URL: http://www.mma.gov.br/port/conama/index.cfm > [2004 jan. $15]$.

CONAMA. Resolução CONAMA nº 005, de 24 de janeiro de 1986. Dispõe sobre a criação de Comissão Especial referente a Amianto/Asbestos. Diário Oficial da União. Brasília, 17 de fevereiro de 1986. Disponível em: <URL: http://www.mma.gov.br/port/conama/index.cfm > [2004 jan. 15]. 
CONAMA. Resolução CONAMA nº 007, de 16 de setembro de 1987. Dispõe sobre a regulamentação do uso do Amianto/Asbestos no Brasil. Diário Oficial da União. Brasília, 22 de outubro 1987, Seção I, Pág. 17.499. Disponível em: <URL: http://www.mma.gov.br/port/conama/index.cfm > [2004 jan. 15].

CONAMA. Resolução CONAMA n 19, de 24 de outubro de 1996. Regulamenta critérios de impressão de legenda em peças que contém amianto (asbestos). Diário Oficial da União. Brasília, 07 de novembro 1996. Disponível em: <URL: http://www.mma.gov.br/port/conama/index.cfm > [2004 jan. 15].

Corrales, M.E. La regulación en periodos de transición: el caso de los servicios de agua potable y saneamiento en America Latina. Buenos Aires, EUDEBA-CLAD, 1998.

Costa Júnior, G.R. Requerimento de informações como instrumento de monitoração legislativa das políticas públicas. Uma pesquisa exploratória 1988/1997. Rio de Janeiro; 1998. [Projeto-tese de Especialização em Políticas Públicas - Escola de Políticas Públicas e Governo da UFRJ].

Costa, N.R. Políticas, justiça distributiva e Inovação - saúde e saneamento na agenda social. São Paulo: HUCITEC, 1998.

Cowell, S.J.; Fairman, R.; Lofstedt, R.E. Use of risk assesment and life cycle assessment in decision making: A common policy research agenda. Risk Analysis. 2002; 22(5):879 - 894.

D'Amato, C.; Torres, J.P.M. e Malm, O. DDT (Dicloro Difenil Tricloroetano): toxicidade e contaminação ambiental - Uma Revisão. Química Nova. 2002; 25(6): 995-1002.

Dahl, R. Democratic theory. Chicago, University of Chicago Press, 1956.

Dye, T.R. Understanding public policy. Englewood Cliffs, NJ. USA: Prentice Hall Inc. 1972. 
Elmore, R. Backward mapping: implementation research and policy decisions. Political Science Quarterly. 1979/80; 94(4).

European Commission. Possibilities for future E.U. environmental policy on plant protection products. Synthesis Reports. 1997. Disponível em: URL: http://europa.eu.int/comm/environment/ppps/synth/complete.pdf. [2004, set.3].

European Commission. Study on a Europe Union wide regulatory framework for levies on pesticides/DG XI. 1999. Disponível em: URL: http://europa.eu.int/comm/environment/enveco/taxation/eimstudy.pdf. [2004, set.1].

European Commission. White Paper on the Strategy for a future Chemicals Policy. 2001 Disponível em: http://europa.eu.int/comm/environment/chemicals/whitepaper.htm. [2004, ago.20].

European Commission. New maximum pesticide limits for food products for human consumption and animal feeding stuffs. 2003 Disponível em: http://europa.eu.int/scadplus/leg/en/lvb/121289.htm. [2004, ago.20].

[FAO] FOOD AND AGRICULTURE ORGANIZATION OF THE UNITED NATIONS. International Code of Conduct on the Distribution and Use of Pesticides. 2002. Disponível em: <URL: http://www.fao.org/WAICENT/FAOINFO/AGRICULT/AGP/AGPP/Pesticid/Code/ PM_Code.htm/> [2004 jan.10].

[FAO] FOOD AND AGRICULTURE ORGANIZATION OF THE UNITED NATIONS. Pesticide Management Unit - Plant Protection Service. 2004. Disponível em: <URL: http://www.fao.org/ag/AGP/AGPP/Pesticid/> [2004 jan.10].

Ferrier, H.; Nieuwenhuijsen, M.; Boobis, A. and Elliott, P. Currente knowledge and recent developments in consumer exposure assessment of pesticides: A UK perspective. Food Additives and Contaminants. 2002; 19(9); 837-852.

Fragomeni, G. Prevention of pesticide-related risk: role of the European Union regulation harmonization. Pesticide Safety News. 1997; 1(jun): 6-7. 
Freitas, C.M.; Porto, M.F.S.; Moreira, J.C.; Pivetta, F.; Machado, J.M.H.; Freitas, N.B.B.;Arcuri, A. S. Segurança química, saúde e ambiente - perspectivas para a governança no contexto brasileiro. Cadernos de Saúde Pública. 2002;18(1):249256.

Freitas, N.B.B.; Arcuri, A.S.A. Regulação e prática internacional em segurança química. Revista Brasileira de Saúde Ocupacional. 1998; 93/94(25): 21-28.

Garcia, A.R.C. Avaliação de risco de uma área contaminada utilizando o modelo C-soil: um estudo de caso. São Paulo; 2000. [Tese de Mestrado - Faculdade de Saúde Pública da USP].

Garcia, EG. Avaliação das conseqüências da "Lei dos Agrotóxicos" nas intoxicações e nas classificações toxicológicas e de potencial de periculosidade ambiental no período de 1990 a 2000. São Paulo; 2001. [Tese de Doutorado Faculdade de Saúde Pública da USP].

Gil, A.C. Como elaborar projetos de pesquisa. São Paulo: ATLAS, 1991.

Gordon L.G. Environmental Health and protection. In: Scutchfield, F.D.; Keck, C.W. organizers. Principles of public health practice. United States: International Thomson Publishing Inc., 1996. p. 300 - 317.

Gustavsson, S. Types of policy and types of politics. Scadinavian Political Studies. 1980, 3 .

Hacon, S. S. Avaliação e gestão de risco ecotoxicológico à saúde humana. In: Azevedo, F.A.A. e Chasin, A.A.M. Coordenadores. As bases ecotoxicológicas da ecotoxicologia. São Carlos: RiMa, 2003 - São Paulo: Intertox, 2003. p. 245-322.

[IARC] INTERNATIONAL AGENCY FOR RESEARCH ON CANCER [Agência Internacional de Pesquisa sobre o Câncer]. List of IARC Evaluations. Last updated: 22 july 2004. Disponível em: URL:www-cie.iarc.fr/monoeval/grlist.html. [5 jan 2005]. 
[IBAMA] Instituto Brasileiro do Meio Ambiente e dos Recursos Naturais Renováveis. Manual de testes para avaliação da ecotoxicidade de agentes

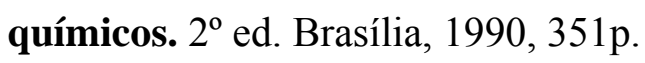

IBAMA. Portaria no 349 de 14 de março de 1990. Estabelece os procedimentos a serem seguidos junto ao IBAMA, para efeito de registros, renovacão de registro e extensão de uso para agrotóxicos seus componentes e afins. Diário Oficial da União. Brasília, 14 de março de 1990. Disponível em: <URL: http://www2.ibama.gov.br/>. [2003 Out. 5].

IBAMA. Portaria $n^{\circ} 139$, de 21 de dezembro de 1994. Estabelece procedimentos a serem adotados junto ao Instituto Brasileiro do Meio Ambiente e dos Recursos Naturais Renováveis - IBAMA, para efeito de avaliação do potencial de periculosidade ambiental de produtos químicos considerados como agrotóxicos, seus componentes e afins, segundo definições estabelecidas nos incisos XX, XXI e XXII, do artigo 2o, do Decreto no 98.816. Disponível em: <URL: http://www.pr.gov.br/agrotoxico/port139.html/>. [2003 Out. 30].

IBAMA. Portaria ${ }^{\circ}$ 84, de 15 de outubro de 1996. Estabelece procedimentos a serem adotados, para efeito de avaliação do potencial de periculosidade ambiental de produtos químicos considerados como agrotóxicos, seus componentes e afins. Diário Oficial da União. Brasília, 18 de outubro de 1996. Disponível em: <URL: http://elegis.bvs.br/leisref/public/showAct.php?id=574\&word= >. [2003 Out. 5].

IBAMA. Portaria Interministerial $n^{\circ} 292$, de 28 de abril de 1989. Obriga o registro junto ao IBAMA das empresas que se dediquem a indústria e comércio de preservativos e preservacão de madeiras. Revoga as Portarias 2748-DN, de 16/03/1972, e a 5-P, de 08/03/1982. Diário Oficial da União. Brasília, 02 de maio de 1989. Disponível em: <URL: http://www2.ibama.gov.br/cgi-bin/wxis/>. [2003 Out. 5].

[IBGE] Instituto Brasileiro de Geografia e Estatística. Indicadores de Desenvolvimento Sustentável - Brasil 2004. Disponível em: <URL: 
http://www.ibge.com.br/home/geociencias/recursosnaturais/ids/terra.pdf $>$ jan.4].

[IFCS] Intergovernmental Forum on Chemical Safety. 2002. Disponível em: <URL:http://www.who.int/ifcs/index.htm>. [2003 Mai 20].

[IPCS/INTOX] International Programme on Chemical Safety. Who/Fao Data Sheet on Pesticides No. 87. 1994. Disponível em <URL: http://www.intox.org/databank/documents/chemical/benomyl/benomyl.htm >. [2005 Jan 10].

[IPCS/INTOX] International Programme on Chemical Safety. IPCS/INTOX Databank. 1999. Disponível em $\quad$ UURL: http:// http://www.intox.org/databank/documents/chemical/benomyl/eics0382.htm>. [2005 Jan 10].

[IPCS/UNITAR] International Programme on Chemical Safety/United Nations Institute for Training and Research. Key elements of a national Programme for chemicals management and safety. Genebra: IOMC. 1998.115 p.

Kingdon, W.J. Agendas, alternatives and public policies. Boston:Little Brown, 1984.

Kiviniemi, M. Public policies and their trajets: a typological elaboration of the concept of implementation. Paris. 1985 (trabalho apresentado na reunião da International Political Science Association - IPSA sobre Policy Implementations and Evaluation)

Kolluru, R.V.; Brooks D.G. Integrated risk assessment and strategic management (Chap. 2). In: Kolluru, R.V.; Bartell S.M.; Pitblado, R.M. e Stricoff, R.S. (Eds.) Risk assessment and management handbook for environmental, health and safety professionals. New York: Mc-Graw-Hill, 1996. p. 2.1-2.23.

Korte, F.; Coulston, F. Some considerations of the impact of energy and chemicals on the environment. Regulatory Toxicology and Pharmacology. 1994.; 19: 219227. 
Layne, C.R. The registration of pesticides in the United States. Pesticidas: Revista de Ecotoxicologia e Meio Ambiente, Curitiba. 1998; 8: 91-100.

Lazarrini, W. Uma vitória dos consumidores. Casa da Agricultura. 1989; 11(jul/ago): 11-12.

Leite, J.R.M. e Ayala, P.A. Direito ambiental na sociedade de risco. Rio de Janeiro: Forense Universitária, 2002. 290 p.

Lemes, V.R.R. Avaliação de resíduos de ditiocarbamatos e etilenotiouréia (ETU) em fruta e sua implicação na saúde pública. São Paulo; 2003. [Tese de MestradoFaculdade de Saúde Pública - USP].

Lieber, R.R.e Romano-Lieber N.S. O Conceito de Risco: Janus Reinventado. In: Minayo, M.C. e Miranda, A.C. Organizadores. Saúde e ambiente sustentável: estreitando nós. Rio de Janeiro: FIOCRUZ, 2002. p. 69- 111.

Lieber, R.R.e Romano-Lieber N.S. Risco, incerteza e as possibilidades de ação em saúde ambiental. Revista Brasileira de Epidemiologia. 2003; 6(2): 121-134.

Luna A.J; Sales, L.T; Silva, R.F. Agrotóxicos: responsabilidade de todos (Uma abordagem da questão dentro do paradigma do desenvolvimento sustentável). Disponível em: URL:http://www.prt6.gov.br/forum/downloads/Artigo1_Adeilson.doc [2004Abr15]

Luna, S.V. Planejamento de Pesquisa: uma introdução. São Paulo:EDUC, 1997.

Machado, C. F. e Minayo, C. G. Análise de riscos tecnológicos na perspectiva das ciências sociais. História, Ciências, Saúde - Manguinhos. Nov. 1996-Fev. 1997; V.III(3):485-504.

Machado, P.A.L. Direito Ambiental Brasileiro. $7^{\mathrm{a}}$ Ed. São Paulo : Malheiros Editora; 1999.

Magalhães, J.P. A evolução do direito ambiental no Brasil. $2^{\mathrm{a}}$ Ed. São Paulo: Editora Juarez de Oliveira, 2002. 88 p. 
Maki, A. W.; Slimak, M.W. The role of ecological risk assessment in environmental decision making. In: Grodzinski. W.; Cowling, E.B.; Breymeuer, A.I. Editors. Ecological Risk: perspectives from Poland and the United States. Washington, D.C.: National Academy Press, 1990. p. 77-87.

[MAPA] MINISTÉRIO DA AGRICULTURA, PECUÁRIA E ABASTECIMENTO.

Insumos Agrícolas. 2004. Disponível em: < URL: http://www.agricultura.gov.br/pls/portal/docs/PAGE/MAPA/ESTATISTICAS/AGRI CULTURA_EM_NUMEROS/43A.XLS>. [2004, Mar, 20].

MAPA. Ministério da Agricultura, Pecuária e Abastecimento / Secretaria de Defesa Sanitária Vegetal. Portaria N. ${ }^{\circ} 22$, de 17 de agosto de 1981b. Estabelece que todo produto defensivo agrícola destinado ao tratamento de sementes para plantio seja obrigatoriamente acrescido de corante. Diário Oficial da União. Brasília, 21 de agosto de 1981, Secção 1, página 15872. Disponível em: < URL:http://oc4j.agricultura.gov.br/agrolegis/do/consultaLei?op=viewTextual\&codig $\mathrm{o}=8934>$. [2004b, Mar, 20].

MAPA. Ministério da Agricultura, Pecuária e Abastecimento. Instrução Normativa $\mathrm{n}^{\mathrm{o}}$ 46, de 24 de julho de 2002. Determinar às empresas titulares de registros de agrotóxicos a retirada das indicações de misturas em tanque dos rótulos e bulas de seus agrotóxicos, no prazo de 30 (trinta) dias. Diário Oficial da União. Brasília, 26 de julho de 2002. Disponível em: $<$ URL: http://oc4j.agricultura.gov.br/agrolegis/do/consultaLei?op=viewTextual\&codigo=13 37>. [2004b, Mar, 20].

MAPA. Ministério da Agricultura, Pecuária e Abastecimento. Portaria n. ${ }^{\circ 25}$, de 21 de setembro de 1981a. Estabelece que todo o defensivo agrícola destinado ao tratamento de sementes seja obrigatoriamente acrescido de corante, a fim de o diferenciar do produto não-tratado. Diário Oficial da União. Brasília, 21 de setembro de 1981, Secção 1, página 17901. Disponível em: < URL: http://oc4j.agricultura.gov.br/agrolegis/do/consultaLei?op=viewTextual\&codigo=14 $50>$. [2004b, Mar, 20]. 
MAPA. Ministério da Agricultura, Pecuária e Abastecimento. Portaria no 329, de 02 de setembro de 1985. Proíbe a comercialização, uso e distribuição de produtos agrotóxicos organoclorados destinados à agropecuária. Diário Oficial da União. Brasília, 03 de setembro de 1985. Disponível em: < URL: http:/elegis.bvs.br/leisref/public/search.php>. [2004b, Mar, 20].

MAPA. Ministério da Agricultura, Pecuária e Abastecimento. Portaria ${ }^{\circ} 45$, de 10 de dezembro de 1990. Estabelece critérios para efeito de obtenção de registro, renovação de registro e extensão de uso de agrotóxicos seus componentes e afins. Disponível em: < URL: http://www.pr.gov.br/agrotoxicos/port45.html>. [2004b, Mar, 20].

MAPA. Ministério da Agricultura, Pecuária e Abastecimento / Secretaria de Defesa Sanitária Vegetal. Portaria $n^{\circ} 82$, de 08 de outubro de 1992. Proibe a producão, exportacão, importacão, comercializacão e utilizacão dos ingredientes ativos Clorobenzilato e Parathion Etilico, destinados a agropecuária. Diário Oficial da União. Brasília, 13 de outubro de 1992. Disponível em: < URL: http://www2.ibama.gov.br/cgi-bin/wxis/>. [2004b, Mar, 20].

MAPA. Ministério da Agricultura, Pecuária e Abastecimento. Portaria ${ }^{\circ}$ 91, de 30 de novembro de 1992b. Proibe a importacao da matéria-prima Hexaclorociclopentadieno usado na fabricacao do Dodedacloro e a producão e comercializacão de iscas formicidas a base de Dodecacloro, no prazo estipulado.

Diário Oficial da União. Brasília, 04 de dezembro de 1992. Disponível em: < URL: http://www2.ibama.gov.br/cgi-bin/wxis/>. [2004 Mar, 20].

MAPA. Ministério da Agricultura, Pecuária e Abastecimento. Portaria $n^{\circ} 84$ de 9 de maio de 1994. Estabelece critérios para avaliar inclusões e exclusões de indicações de usos nos registros dos agrotóxicos. Diário Oficial da União. Brasília, 17 de maio de 1994. Disponível em: <URL: http://www.pr.gov.br/agrotoxicos/port84.html>. [2004 Mai. 2].

MAPA. Ministério da Agricultura, Pecuária e Abastecimento. Portaria ${ }^{0}$ 67, de 30 de maio de 1995. Dispõe sobre a mistura em tanque de agrotóxicos ou afins 
registrados no Ministério da Agricultura, do Abastecimento e da Reforma Agrária. Diário Oficial da União. Brasília, 08 de junho de 1995. Disponível em: <URL: http://e-legis.bvs.br/leisref/public/showAct.php?id=570\&word=>. [2003 Out. 5].

MAPA. Ministério da Agricultura, Pecuária e Abastecimento. Portaria n ${ }^{\circ} 160$ de 31 de dezembro de 1996. Para efeito de obtenção de registro e reavaliação técnica de agrotóxicos, seus componentes e afins, e em complementação às Portarias $n^{\circ} 45$, de 10 de dezembro de 1994 e no 84 de 9 de maio de 1994. Diário Oficial da União. Brasília, 14 de janeiro de 1997. Disponível em: < URL: http://oc4j.agricultura.gov.br/agrolegis/do/consultaLei>. [2004, Mar, 20].

Margni, M.; Rossier, D.; Crettaz, P.; Jolliet, O. Life cycle impact assessment of pesticides on human health and ecosystems. Agriculture, Ecosystems and Environment. 2002; 93: 379 - 392.

Meirelles, H., Carrara Jr, E. A Indú stria Química e o Desenvolvimento do Brasil. São Paulo: Metalivros, 1996.

Meter, D. E Van Horn, C. The policy implementation process. A conceptual framework. Administration and Society, 6(4), 1975.

Minayo, M.C.S. e Miranda, A. C. Saúde e ambiente sustentável: estreitando nós. Rio de Janeiro: FIOCRUZ, 2002. 343 p.

[MMA] Ministério do Meio Ambiente. Perfil Nacional da gestão de Substâncias Químicas. Brasília: MMA, 2003. 280p.

[MMA] Ministério do Meio Ambiente. Notícias: Marina pede menos discursos e mais ações pela biodiversidade. 19/02/2004. 2004a. Brasília. Disponível em: <URL: http://www.mma.gov.br/> . [2004, Fev, 22].

Moraes, A.C.R. Meio ambiente e ciências humanas. São Paulo: Hucitec; 1994.

Moreira, J.C.; Jacob, S.C.; Peres, F.; Lima, J.S.; Meyer, A.; Oliveira-Silva, J.J.; Sarcinelli, P.N.; Batista, D.F.; Egler, M.; Faria, M.V.C.; Araújo, A.J.; Kubota, A.H.; Soares, M.O.; Alves, S.R.; Moura, C.M.; Curi, R. Avaliação integrada do impacto do 
uso de agrotóxicos sobre a saúde humana em uma comunidade agrícola de Nova Friburgo, RJ. Ciência e Saúde Coletiva. 7(2), 299-311.

MS. Ministério da Saúde. Secretaria de Vigilância Sanitária. Portaria $n^{0}$ 14, de 24 de janeiro de 1992. Estabelece os critérios para a avaliação toxicológica preliminar para agrotóxicos e afins destinados á pesquisas e experimentação e dá outras providências. Diário Oficial da União. Brasília, de 28 de janeiro de 1992. Disponível em: $\quad<U R L: \quad h t t p: / / e-$ legis.bvs.br/leisref/public/showAct.php?id=560\&word=/>. [2003 Out. 30].

MS. Ministério da Saúde. Portaria $\mathrm{n}^{0}$ 11, de 08 de janeiro de 1998. Exclui da "Relação de Substâncias com Ação Tóxica sobre Animais ou Plantas, cujo registro pode ser Autorizado no Brasil, em Atividades Agropecuárias e Produtos Domissanitários", constante da Portaria $n^{\circ} 10$, de 8 de março de 1985, D.0.U. de 14.03.85, Anexos I e II, as seguintes monografias: A-09 Aldrin, B-04 B.H.C, C-16 Clorobenzilato, D-07 DDT, E-03 Endrin, H-01 Heptacloro, L-01 Lindano, P-02 Paration e P-24 P.C.P. Diário Oficial da União. Brasília, de 21 de janeiro de 1998. Disponível em: <URL: http://e-legis.bvs.br/leisref/public/search.php>. [2003 Out. 30].

MS. Ministério da Saúde. Portaria n. ${ }^{\circ}$ 1.469, de 29 de Dezembro de 2000. Estabelece os procedimentos e responsabilidades relativos ao controle e vigilância da qualidade da água para consumo humano e seu padrão de potabilidade, e dá outras providências. Diário Oficial da União. Brasília, de 10 de janeiro de 2001. Disponível em: <URL: http://elegis.bvs.br/leisref/public/showAct.php?id=50\&word=>. [2003 Out. 30].

MS. Ministério da Saúde. Portaria $n^{\circ} 518$, de 25 de março de 2004. Estabelece os procedimentos e responsabilidades relativos ao controle e vigilância da qualidade da água para consumo humano e seu padrão de potabilidade, e dá outras providências. Diário Oficial da União. Brasília, de 26 de março de 2004. Disponível em: <URL: http://e-legis.bvs.br/leisref/public/search.php>. [2003 Out. 30]. 
[MTE] MINISTÉRIO DO TRABALHO E EMPREGO. Comissão Nacional Permanente do Benzeno. Disponível em: <URL: http://www.mte.gov.br/empregador/segsau/comissoestri/cnpb/conteudo/oquee.asp / > [2004, Mai, 5].

[MTE] Ministério do Trabalho e Emprego. Norma Regulamentadora Rural - NRR 5 - Produtos Químicos (155.000-4). Disponível em: <URL: http://www.mte.gov.br/empregador/segsau/legislacao/normas/conteudo/nrr5/default. asp $>[2004, \operatorname{dez}, 5]$.

MTE. Ministério do Trabalho e Emprego. Portaria Interministerial n ${ }^{\circ} 775$, de 28 de Abril de 2004. Proíbe a comercialização de produtos acabados que contenham "benzeno" em sua composição, admitindo, porém, alguns percentuais. Disponível em: $<$ URL: http:// http://www.mte.gov.br/empregador/segsau/legislacao/portarias/2004/conteudo/4903. $\operatorname{asp} />[2004, \operatorname{dez}, 5]$.

Nardocci, AC. Risco como Instrumento de Gestão Ambiental. São Paulo; 1999. [Tese de Doutorado - Faculdade de Saúde Pública da USP].

Navarro, A.L. O Direito à saúde do adolescente: uma avaliação das políticas públicas. São Paulo; 2001. [Tese de Mestrado - Faculdade de Saúde Pública da USP].

[NRC] National Research Council. Risk Assessment in the Federal Government: managing the process. Washington D.C.: National Academy Press; 1983.

[NRC] National Research Council. Science and judgment in risk assessment. Washington D.C.: National Academy Press; 1994.

[NRC] National Research Council. The future role of pesticides in US agriculture. Washington D.C.: National Academy Press; 2000. Disponível em: <URL http://www.nap.edu>. [Aug 31 2004]

Nunes, G.S. e Ribeiro, M.L. Pesticidas: uso, legislação e controle. Pesticidas: Revista de Ecotoxicologia e Meio Ambiente. 1999; 3: 31-44. 
[OECD] Organization for Economic Co-operation and Development. Environmental Outlook for the chemicals industry. Paris - França. OECD Environment Directorate - Environment Health and Safety Publications. 2001. 64 p.

[OPAS] Organização Pan-americana da Saúde/Organização Mundial da Saúde Representação do Brasil. Manual de Vigilância da Saúde de Populações Expostas a Agrotóxicos. 1996. Disponível em: < URL http://www.opas.org.br/ambiente/temas_documentos_detalhe.cfm?id=45\&iddoc $=58$. [2, Mai, 2004]

Ordóñez, G. A. Salud ambiental: conceptos y actividades. Revista Panamericana Salud Publica/ PanAm Journal of Public Health. 2000; 7(3): 137-147.

Penteado, J. C. P.; Vaz, J. M. O legado das Bifenilas Policloradas (PCBs). Química Nova. $2001 ; 24$ (3): 390-98.

Pereira, P. Análise de Risco Ambiental de processo siderúrgico. São Paulo; 1998. [Tese de Doutorado - Faculdade de Saúde Pública da USP].

Pessanha, B.M.R. e Menezes, F.A.F. A questão dos agrotóxicos. Agroanalysis. 1985; V9(9): 2-22.

[PIC] Rotterdam Convention on the Prior Informed Consent Procedure for Certain Hazardous Chemicals and Pesticides in International Trade. 2004. Disponível em: < URL: http://www.pic.int/> . [2004 Fev. 16].

Pittinger, C.A.; Brennan, T.H.; Badger, D.A.; Hakkinen. P.J.; Fehrenbacher, M.C. Aligning chemical assessment tools across the hazard-risk continuun. Risk Analysis. $2003 ; 23(3): 529-35$.

[POPs] Stockholm Convention On Persistent Organic Pollutants (POPs). 2004. Disponível em: < URL: http://www.pic.int/> . [2004 Fev.16].

Porto, M.F.S.; Freitas, C.M. Análise de riscos tecnológicos ambientais: perspectivas para o campo da saúde do trabalhador. Cad. Saúde Pública. 1997; 13(2): 59-72. 
Presidential/Congressional Commission on Risk Assessment and Risk Management. Framework for Environmental Health Risk Management. Final Report. Volume 1. Washington, DC; 1997.

Ribeiro, M.A .Ecologizar: pensando o ambiente humano. Belo Horizonte: Rona Editora, 1998. 390p.

Rodricks, J.V Calculated risks: Understanding the toxicity and human health risks of chemicals in our environment. Great Britain: Cambridge University Press, 1992. 256p.

Rodrigues. F.A.M. A gestão ambiental na industria química brasileira: uma comparação entre a visão externa do próprio segmento. Rio de Janeiro, 2001 [Tese de Mestrado - COPPE/UFRJ]. Disponível em: <URL: http://wwwt.interacaoambiental.com.br/altino/ >. [2002 Out. 2].

Rogers, M.D. Risk analysis under certainty, the Precautionary Principle, and the new EU chemicals strategy. Regulatory Toxicology and Pharmacology. 2003; 37: 370 -381 .

Rua, M.G. As políticas públicas e a juventude dos anos 90. In: Jovens acontecendo nas trilhas das políticas públicas. Brasília: CNPD, 1998. 2 v. p. 731 - 749.

Sanchez, M. C. Regulação como instrumento das políticas públicas do Estado contemporâneo: Agência Nacional de Saúde Suplementar - ANS. São Paulo; 2001. [Dissertação de Mestrado - Faculdade de Saúde Pública da USP].

Serpa, R. R. As metodologias de análises de riscos e seu papel no licenciamento de indústrias e atividades perigosas. In: Freitas C.M. (Org.). Acidentes Industriais Ampliados: desafios e perspectivas para o controle e a prevenção. 20 ed. Rio de Janeiro: Editora FIOCRUZ, 2000. p. 253-266.

Silva, C.M.M.S.; FAY, E.F. Impacto ambiental do regulador de crescimento vegetal paclobutrazol. Jaguariúna: EMBRAPA Meio Ambiente, 2003. 
Silva, E.L.; Menezes, E.M. Metodologia da pesquisa e elaboração de dissertação. Florianópolis:Laboratório de Ensino a Distância da UFSC, 2001. 121p.

Silva, J. J. O.; Alves, S.; Meyer, A .; Perez, F.; Sarcinelli, P. N.; Mattos, R. C. O. C.; Moreira, J.C. Influência de fatores socioeconômicos na contaminação por agrotóxicos, Brasil. Revista Saúde Pública. 2001; 35(2):130-135.

Silva, P.L.B; Melo, M.A.B. O processo de implementação de políticas públicas no Brasil: características e determinantes da avaliação de programas e projetos. Campinas: UNICAMP; Núcleo de Estudos de Políticas Públicas (NEPP). Caderno $n^{\circ} 48,2000$.

[SINDAG] Sindicato Nacional da Indústria de Produtos para Defesa Agrícola. Disponível em: <URL: http://www.sindag.com.br> [2002 Out.16].

[SINITOX] Sistema Nacional de Informações Tóxico-farmacológicas. Disponível em: <URL:http://www.fiocruz.br/sinitox/> [2003 Mai. 20].

Sobreira. A. E.G.; Adissi, P.J. Agrotóxicos: falsas premissas e debates. Ciência e Saúde Coletiva. 2003; 8(4): 985 - 990.

Spink, M.J.P. Tópicos do discurso sobre risco: risco-aventura como metáfora na modernidade tardia. Cad. Saúde Pública. 2001; 17(6): 1277-1311.

[SRA] Society for Risk Analysis. Glossary of Risk Analysis terms. 2003. Disponível em: <URL:http://www.sra.org.gloss3.html >. [2003 Mai. 20].

Suter II, G.W.; Munns, Jr. W.R.; Sekizawa, J. Types os integration in risk assessment and management, and why they are needed. Human and Ecological Risk Assessment. 2003;9(1):273-279.

Tomita, R.Y. Toxicidade de mistura de agrotóxicos em ambiente aquático reflexos na saúde pública da exposição simultânea aos herbicidas atrazina e diuron. São Paulo; 2004. [Tese de Doutorado - Faculdade de Saúde Pública da USP]. 
[UN] UNITED NATIONS. Report of the United Nations Conference on Environment and Development. Annex I - Rio Declaration on Environment and Development. $1992 . \quad$ Disponível em: URL http://www.un.org/documents/ga/conf151/aconf15126-1annex1.htm>. [2003 Dez. 7]. [UN] UNITED NATIONS. Report of the World Summit on Sustainable Development. 2002. Disponível em: <URL: http://www.johannesburgsummit.org/html/documents/documents.html>.[2003 Dez.7].

[UNEP] UNITED NATIONS ENVIRONMENTAL PROGRAMME. Declaration of the United Nations Conference on the Human Environment. 1972. Disponível em: <URL:http://wwwwww.unep.org/ > [2003 Mai. 7].

[UNEP] UNITED NATIONS ENVIRONMENTAL PROGRAMME. The London Guidelines, Including Prior Informed Consent. 1987. Disponível em: <URL: http://www.chem.unep.ch/irptc/irptc/lguide.html/ > [2003 Mai. 7].

[UNEP] UNITED NATIONS ENVIRONMENTAL PROGRAMME. UNEP Activities in Chemicals. 2004. Disponível em: <URL: http://www.unep.org/themes/chemicals/>. [2004 Jan. 10].

[UNEP/IPCS] UNITED NATIONS ENVIRONMENTAL PROGRAMME / INTERNATIONAL PROGRAMME ON CHEMICAL SAFETY. Chemical Risk Assessment. 1999 [Training Model No. 3].

[UNITAR] UNITED NATIONS INSTITUTE FOR TRAINNING AND RESEARCH. Developing e Strengthening National Legislation and Policies for the Management of Chemicals. 1999. [Observações e conclusões do encontro internacional de especialistas - Relatório Final].

[USEPA] UNITED STATES ENVIRONMENTAL PROTECTION AGENCY. Framework for ecological risk assessment. Washington, DC: Risk Assessment Forum. 1992. [EPA/630/R-92/001]. 
[USEPA] UNITED STATES ENVIRONMENTAL PROTECTION AGENCY. Guidelines for Ecological Risk Assessment. Washington, DC: Risk Assessment Forum. 1998. [EPA/630/R-95/002F].

[USEPA] UNITED STATES ENVIRONMENTAL PROTECTION AGENCY. About EPA's Pesticides Program. 2004a. Disponível em: <URL: http://www.epa.gov/pesticides/about/aboutus.htm >. [2003 Dez 10].

[USEPA] UNITED STATES ENVIRONMENTAL PROTECTION AGENCY.U.S. Perspective: Probabilistic Risk Assessments and Their Use in Risk Management Decisions. 2004b. Disponível em: http://www.epa.gov/oppefed1/ecorisk/rmd.htm>. [2004 Set. 2].

Vermeire T.; MacPhail R.; Waters, M. Integrated Human and Ecological Risk Assessment: A Case Study of Organophosphorous Pesticides in the Environment Human and Ecological Risk Assessment: 2003; V 9 (1): 343-357.

Viana, A.L. Abordagens metodológicas em políticas públicas. Revista de Administração Pública. Rio de Janeiro 1996; 30(2): 29-46.

Visentin, S.; Mariani, F.; Ronchin, M. The monitoring of pesticide residues en food in Europe: the results and future prospects. Pesticide Safety News. 2003; Issue 7(3). Disponível em: <URL: http://www.icps.it/ >. [2004 Set. 3].

[WHO] World Health Organization. Public health impact of pesticides used in agriculture. Geneva: WHO; 1985.

[WHO] World Health Organization. Environmental and health, the european charter and commentary. In: First European Conference on Environment and Health. Frankfurt: Regional Publication (European Series, 35); 1990.

[WHO Europe] - World Health Organization Regional Office for Europe. Environmental health policy. 2003. Disponível em: <URL: http://www.euro.who.int/envhealthpolicy>. [2003 Dez. 10]. 
Wongtschowski, P. Indústria química - Risco e oportunidades.São Paulo - SP. Ed. Edgard Blücher Ltda. 1999. 215 p.

Zadocks, J.C.; Waibel, H. From pesticide to genetically modified plants: history, economics and politics. Netherlands Journal of Agricultural Science: 2000; V 48: 125-149. 
11 ANEXOS 


\subsection{Anexo I}

TABELA 4. Sumário das responsabilidades das instituições federais brasileiras, envolvidas no gerenciamento de substâncias químicas.

Instituição $\quad$ Responsabilidade

Ministério do Meio Ambiente

Formulação de políticas nacionais relacionadas a resíduos perigosos e urbanos, produção mais limpa, consumo sustentável, educação ambiental, mudanças climáticas, camada de Ozônio e outros. Proposição de estratégias, mecanismos e instrumentos econômicos e sociais. Execução da política nacional de meio ambiente po rmeio do IBAMA - Instituto Brasileiro do Meio Ambiente e dos Recursos Naturais Renováveis.

Comissão intersetorial: preside o CONAMA - Conselho Nacional de Meio Ambiente, de cunho intersetorial, com participação de representantes federais, estaduais e municipais, entidades de trabalhadores e da sociedade civil e entidades empresariais, na regulação de diferentes temas afetos ao meio ambiente, incluindo substâncias e resíduos perigosos.

Preside a CONASQ - Comissão Nacional de Segurança Química, de cunho intersetorial, que tem como principal objetivo a articulação institucional e fomento de discussões sobre segurança química. Trabalha para implementar o PRONASQ Programa Nacional de Segurança Química. Participam desta comissão 22 instituições do setor público, privado e de organizações não-governamentais.

Grupos de Trabalho: GT-PIC e GT-POPs - Grupos de trabalho interministerial para ratificação das Convenções de Roterdã (PIC) e de Estocolmo (POPs), respectivamente.

Atuação: Importação de produtos inorgânicos, orgânicos, agrotóxicos, metais e seus compostos e asbestos (amianto); produção de agrotóxicos e asbestos (amianto); armazenamento de agrotóxicos e metais e seus compostos; distribuição e comercialização asbestos (amianto); uso e manuseio de agrotóxicos, seus resíduos e afins e asbestos (amianto).

Ministério da Saúde

Formulação e implementação da política nacional de saúde e saúde ambiental. A regulamentação, o controle e a fiscalização, de produtos e substâncias químicas da ANVISA - Agência Nacional de Vigilância Sanitária. A FIOCRUZ - Fundação Oswaldo Cruz promove atividades de ensino, pesquisa e publicações. A FUNASA - Fundação Nacional de Saúde, executa ações voltadas para o saneamento ambiental e de atenção integral à sáude dos povos indígenas, e possui na sua estrutura a Coordenação Geral de Vigilância Ambiental em Saúde (CGVAM)

O Ministério da Saúde é o órgão responsável pela rotulagem e controle de produtos dietéticos, de higiene, perfumarias, cosméticos, corantes, além de participar do processo de registro de agrotóxicos e afins.

Comissão Interinstitucional: Comissão Interinstitucional da Saúde do Trabalhador (CIST) - debater e propor políticas públicas 


\begin{tabular}{ll}
\hline Instituição & Responsabilidade \\
\hline na área de saúde do trabalhador. Composta por vários ministérios, representantes dos empregadores e trabalhadores.
\end{tabular}

na área de saúde do trabalhador. Composta por vários ministérios, representantes dos empregadores e trabalhadores.

Atuação: Importação de farmoquímicos e agrotóxicos e afins; produção de inorgânicos, orgânicos e farmoquímicos; armazenamento e transporte de farmoquímicos e agrotóxicos e afins; distribuição e comercialização, uso e manuseio de inorgânicos, orgânicos, farmoquímicos e agrotóxicos e afins; Disposição final de farmoquímicos e agrotóxicos e afins.

Ministério do Trabalho e Formula e propõe as diretrizes de inspeção do trabalho e normas de atuação da área de segurança e saúde do trabalhador. A Emprego FUNDACENTRO - Fundação Jorge Duprat Figueiredo de Segurança e Medicina do Trabalho, planeja, coordena, acompanha e avalia programas, pesquisas e serviços na área de higiene do trabalho.

Comissão Tripartite Paritária Permanente (CTPP): instância de consulta para elaboração de política e diretrizes na área de segurança e saúde do trabalhador. Participam representantes do governo, dos empregadores e dos trabalhadores.

Comissão Intersetorial: Comissão Nacional Permanente do Benzeno (CNPBz) - instância tripartite consultiva para atividades relacionadas ao gerenciamento do benzeno. Participam também os ministérios da Previdência e Assistência Social, da Saúde e da Indústria e Comércio, além dos representantes da indústria e dos trabalhadores.

Grupo de Estudos: grupo tripartite interministerial, para implementação da Convenção OIT 174 - Acidentes Industriais Ampliados.

Atuação: Importação de Agrotóxicos; produção de inorgânicos, orgânicos, farmoquímicos, agrotóxicos, tintas/vernizes/lacas/afins, preparados e asbestos (amianto); armazenamento de agrotóxicos; distribuição e comercialização de agrotóxicos; uso e manuseio de inorgânicos, orgânicos, farmoquímicos e agrotóxicos, tintas/vernizes/lacas/afins, preparados, metais e seus compostos e asbestos (amianto).

Ministério dos Transportes

Política nacional de transportes. As agências ANTAQ - Agência Nacional de Transporte Aquaviários e ANTT - Agência Nacional de Transportes Terrestres estabelecem padrões e normas técnicas complementares relativas às operações de transporte terrestre e aquaviário de cargas especiais perigosas.

Atuação no transporte de todas as substâncias.

Ministério da Agricultura, Política nacional agrícola. Agrotóxicos.

Pecuária e Abastecimento MAPA

Comitê Interministerial: Comitê Técnico de Assessoramento de Agrotóxicos (CTA) - tem como objetivo tratar questões relacionadas aos agrotóxicos (procedimentos técnicos-científicos e administrativos, elaboração de rotinas e procedimentos, incorporação de novas tecnologias, usos emergenciais de agrotóxicos).

Atuação: Importação, produção, armazenamento, transporte, distribuição/comercialização, uso/manuseio, emergências e 


\begin{tabular}{|c|c|}
\hline Instituição & Responsabilidade \\
\hline & disposição final de agrotóxicos. \\
\hline \multirow[t]{2}{*}{$\begin{array}{l}\text { Ministério do Desenvolvimento, } \\
\text { Indústria e Comércio Exterior - } \\
\text { MDIC }\end{array}$} & $\begin{array}{l}\text { Estabelecer a política de desenvolvimento da indústria e a metrologia, a normalização e a qualidade industrial. Atua também por } \\
\text { meio do CONMETRO - Conselho Nacional de Metrologia, Normalização e Qualidade Industrial e do INMETRO - Instituto } \\
\text { Nacional de Metrologia, Normalização e Qualidade. }\end{array}$ \\
\hline & $\begin{array}{l}\text { Atuação: Importação de inorgânicos, orgânicos, farmoquímicos, agrotóxicos, tintas/vernizes/lacas/afins, preparados, metais e } \\
\text { seus compostos e asbestos (amianto); Produção de inorgânicos, orgânicos, farmoquímicos, agrotóxicos, } \\
\text { tintas/vernizes/lacas/afins, preparados, metais e seus compostos e asbestos (amianto); Distribuição e comercialização de } \\
\text { inorgânicos, orgânicos, farmoquímicos, agrotóxicos, tintas/vernizes/lacas/afins, preparados, metais e seus compostos e asbestos } \\
\text { (amianto). }\end{array}$ \\
\hline \multirow{2}{*}{$\begin{array}{l}\text { Ministério das Relações } \\
\text { Exteriores }\end{array}$} & Articulação da posição brasileira em negociações internacionais. \\
\hline & Atuação: Importação de inorgânicos, orgânicos, farmoquímicos, agrotóxicos, metais e seus compostos. \\
\hline \multirow[t]{3}{*}{$\begin{array}{l}\text { Ministério } \\
\text { Tecnologia }\end{array}$} & $\begin{array}{l}\text { Formulação e implementação da política nacional de ciência e tecnologia. Atua por meio do CNPq - Conselho Nacional de } \\
\text { Desenvolvimento Científico e Tecnológico, na promoção e fomento do desenvolvimento científico e tecnológico do país. }\end{array}$ \\
\hline & $\begin{array}{l}\text { Comissão Interministerial: Comissão Interministerial da Convenção de Prevenção de Armas Químicas - CPAQ, composta por } 5 \\
\text { ministérios. }\end{array}$ \\
\hline & Responsabilidades ligadas à produção e disposição final de substâncias químicas. \\
\hline Ministério de Minas e Energia & $\begin{array}{l}\text { Responsabilidades ligadas à importação de inorgânicos, metais e seus compostos e asbestos (amianto); Uso e manuseio de } \\
\text { inorgânicos e asbestos (amianto); Disposição final de metais e seus compostos e asbestos (amianto). }\end{array}$ \\
\hline \multirow[t]{2}{*}{ Ministério da Justiça } & Prevenir e reprimir o tráfico de entorpecentes. \\
\hline & Atuação no controle de substâncias envolvidas no refino da cocaína. \\
\hline \multirow[t]{3}{*}{ Ministério da Defesa } & Marinha: Prevenção da poluição ambiental (óleo e outras substâncias consideradas poluentes). \\
\hline & Aeronáutica: fiscalização e controle do transporte aéreo de mercadorias perigosas. \\
\hline & $\begin{array}{l}\text { Atuação: Importação de inorgânicos e preparados; Uso e manuseio de orgânicos, tintas/vernizes/lacas/afins, preparados; } \\
\text { Disposição final de asbestos (amianto). }\end{array}$ \\
\hline
\end{tabular}




\begin{tabular}{ll}
\hline Instituição & Responsabilidade \\
\hline Ministério da Fazenda & $\begin{array}{l}\text { A Secretaria da Receita Federal - SRF, subordinada ao Ministério, dispõe de duas coordenações para o controle de substâncias } \\
\text { que entram no país: Coordenação Geral de Fiscalização - Cofis e Coordenação Geral de Administração Aduaneira - Coana. } \\
\text { Atuação: Importação de inorgânicos, orgânicos, farmoquímicos, agrotóxicos, metais e seus compostos e asbestos (amianto); } \\
\text { Distribuição e comercialização de inorgânicos, orgânicos, farmoquímicos, agrotóxicos, tintas/vernizes/lacas/afins, preparados, } \\
\text { metais e seus compostos e asbestos (amianto). }\end{array}$ \\
$\begin{array}{l}\text { Ministério } \\
\begin{array}{l}\text { Regional } \\
\text { Ministérios Públicos - Federal e } \\
\text { Estadual }\end{array}\end{array}$ & $\begin{array}{l}\text { Conselho Nacional de Defesa Civil - atuação em emergências, incluindo acidentes químicos. } \\
\text { Comentação ou aperfeiçoamento legal e na fiscalização e cumprimento dos preceitos legais estabelecidos. }\end{array}$ \\
\hline
\end{tabular}

\section{Fonte: MMA. 2003}




\subsection{Anexo II}

TABELA 5. Legislação Federal sobre Substâncias Químicas - exceto Agrotóxicos

\section{DÉCADA DE 1920}

\begin{tabular}{|l|l|l|l|l|}
\hline $\begin{array}{l}\text { Instrumento } \\
\text { Legal }\end{array}$ & $\begin{array}{l}\text { Órgão(s) } \\
\text { Envolvido(s) } \\
\text { na Aplicação }\end{array}$ & $\begin{array}{l}\text { Substâncias } \\
\text { Químicas } \\
\text { Contempladas }\end{array}$ & Objetivo da Legislação & Competência - Referência \\
\hline $\begin{array}{l}\text { Decreto } \mathrm{n}^{\text {o }} \\
16.300,31 \mathrm{de} \\
\text { dezembro de } \\
1923\end{array}$ & MS & Geral & $\begin{array}{l}\text { Regulamento de Saúde Pública. Impedia que fábricas e oficinas prejudicassem } \\
\text { a saúde dos moradores e de sua vizinhança, possibilitando o isolamento e o } \\
\text { afastamento de indústrias nocivas ou incômodas. }\end{array}$ & BRASIL, 1923 \\
\hline
\end{tabular}

\section{DÉCADA DE 1930}

\begin{tabular}{|c|c|c|c|c|}
\hline $\begin{array}{l}\text { Instrumento } \\
\text { Legal }\end{array}$ & $\begin{array}{l}\text { Órgão(s) } \\
\text { Envolvido(s) } \\
\text { na Aplicação }\end{array}$ & $\begin{array}{l}\text { Substâncias } \\
\text { Químicas } \\
\text { Contempladas } \\
\end{array}$ & Objetivo da Legislação & Competência - Referência \\
\hline $\begin{array}{l}\text { Decreto } \mathrm{n}^{\mathrm{o}} \\
23.629 \text { de } 23 / 12 \\
\text { de } 1933\end{array}$ & - & \begin{tabular}{|l|} 
Explosivos, \\
corrosivos e \\
produtos \\
agressivos em \\
geral \\
\end{tabular} & $\begin{array}{l}\text { Regulamentou o embarque e desembarque de inflamáveis, explosivos, } \\
\text { corrosivos e produtos agressivos em geral no porto do Rio de Janeiro }\end{array}$ & BRASIL, 1933. \\
\hline $\begin{array}{l}\text { Decreto } \mathrm{n}^{\mathrm{O}} \\
23.777, \text { de } 23 \text { de } \\
\text { janeiro de } 1934 .\end{array}$ & - & Resíduo orgânico & $\begin{array}{l}\text { Regulamentou o lançamento obrigatório de resíduo industrial das usinas } \\
\text { açucareiras ("vinhoto", "tiborna" ou "caxixi") nas águas fluviais, determinando } \\
\text { que sejam "longe das margens, em lugar fundo e correntoso". }\end{array}$ & BRASIL, 1934a. \\
\hline
\end{tabular}

\section{DÉCADA DE 1960}

\begin{tabular}{|c|c|c|c|c|}
\hline $\begin{array}{l}\text { Instrumento } \\
\text { Legal }\end{array}$ & $\begin{array}{l}\text { Órgão(s) } \\
\text { Envolvido(s) } \\
\text { na Aplicação }\end{array}$ & $\begin{array}{l}\text { Substâncias } \\
\text { Químicas } \\
\text { Contempladas }\end{array}$ & Objetivo da Legislação & Competência - Referência \\
\hline $\begin{array}{l}\text { Decreto } n^{\circ} \\
49.974, \text { de } \\
21 / 01 / 1961\end{array}$ & MS & Várias substâncias & $\begin{array}{l}\text { Código Nacional de Saúde. Definiu que os produtos para agricultura, que } \\
\text { contenham substâncias tóxicas, devem ser registrados e controlados por } \\
\text { repartição federal competente. O rótulo deve mostrar a composição química, }\end{array}$ & BRASIL, 1961a. \\
\hline
\end{tabular}




\begin{tabular}{|c|c|c|c|c|}
\hline & & & destacar que constitui produto "venenoso" e seu antídoto. & \\
\hline $\begin{array}{l}\text { Decreto } n^{0} \\
50.877, \text { de } 29 \text { de } \\
\text { junho de } 1961\end{array}$ & MAPA & $\begin{array}{l}\text { Resíduos tóxicos e } \\
\text { óleo }\end{array}$ & $\begin{array}{l}\text { Dispõe sobre o lançamento de resíduos tóxicos ou oleosos nas águas interiores } \\
\text { ou litorâneas do País. Define "poluição" e define padrões para águas serem } \\
\text { consideradas poluídas. }\end{array}$ & BRASIL, 1961b. \\
\hline $\begin{array}{l}\text { Decreto } \mathrm{n}^{\mathrm{o}} \\
55.649, \text { de } 28 \text { de } \\
\text { janeiro de } 1965\end{array}$ & Min. Guerra & $\begin{array}{l}\text { Armas, munições, } \\
\text { artigos } \\
\text { pirotécnicos, } \\
\text { pólvoras, } \\
\text { explosivo, } \\
\text { produtos químicos } \\
\text { básicos e } \\
\text { agressivos, etc. }\end{array}$ & $\begin{array}{l}\text { Regulamentou as normas para a fiscalização da fabricação, recuperação, } \\
\text { manutenção, utilização industrial, manuseio, exportação, importação, } \\
\text { desembaraço alfandegário, armazenamento, comércio e tráfego de várias } \\
\text { substâncias. }\end{array}$ & BRASIL, 1965a. \\
\hline
\end{tabular}

\section{DÉCADA DE 1970}

\begin{tabular}{|c|c|c|c|c|}
\hline $\begin{array}{l}\text { Instrumento } \\
\text { Legal }\end{array}$ & $\begin{array}{l}\text { Órgão(s) } \\
\text { Envolvido(s) } \\
\text { na Aplicação }\end{array}$ & $\begin{array}{l}\text { Substâncias } \\
\text { Químicas } \\
\text { Contempladas } \\
\end{array}$ & Objetivo da Legislação & Competência - Referência \\
\hline $\begin{array}{l}\text { Decreto-Lei } n^{\circ} \\
1.413 \text {, de } 14 \text { de } \\
\text { agosto de } 1975\end{array}$ & - & Geral & $\begin{array}{l}\text { Controle da poluição do meio ambiente provocada por atividades industriais. } \\
\text { Definiu a adoção do esquema de zoneamento urbano }\end{array}$ & BRASIL, 1975a. \\
\hline $\begin{array}{l}\text { Decreto } \mathrm{n}^{\circ} \\
76.389 \text {, de } 03 \text { de } \\
\text { outubro de } 1975 \text {. }\end{array}$ & $\begin{array}{l}\text { MDIC, } \\
\text { SEMA, IBGE }\end{array}$ & $\begin{array}{l}\text { Atividades } \\
\text { industriais }\end{array}$ & $\begin{array}{l}\text { Dispõe sobre as medidas de prevenção e controle da poluição industrial de que } \\
\text { trata o Decreto-Lei 1.413, de } 14 \text { de agosto de } 1975 \text {. Define poluição industrial, } \\
\text { estabelece áreas críticas de poluição, institui o cadastro de estabelecimentos } \\
\text { industriais na Secretaria de Tecnologia Industrial (Ministério da Indústria e do } \\
\text { Comércio) em articulação com a SEMA (Ministério do Interior) e suporte do } \\
\text { IBGE. Estabelece o Programa Tecnológico de Prevenção da Poluição } \\
\text { Industrial. }\end{array}$ & BRASIL, 1975b. \\
\hline $\begin{array}{l}\text { Lei } \mathrm{n}^{\circ} 6.368, \text { de } \\
21 \text { de outubro de } \\
1976\end{array}$ & $\mathrm{MS}, \mathrm{MJ}$ & Farmoquímicos & $\begin{array}{l}\text { Dispõe sobre medidas de prevenção e repressão ao tráfico ilícito e uso indevido } \\
\text { de substâncias entorpecentes ou que determinem dependência física ou } \\
\text { psíquica. }\end{array}$ & \\
\hline $\begin{array}{l}\text { Decreto } n^{\circ} \\
79.094, \text { de } 5 \text { de } \\
\text { janeiro de } 1977\end{array}$ & MS & Domissanitários & Regulamenta a Lei $\mathrm{n}^{\circ} 6.360$, de 23 de setembro de 1976 & \\
\hline
\end{tabular}




\begin{tabular}{|l|l|l|l|l|}
\hline $\begin{array}{l}79.437, \text { de } 28 \text { de } \\
\text { março de } 1977\end{array}$ & & Causados por Poluição por Óleo, 1969 \\
\hline $\begin{array}{l}\text { Lei n } 6.514, \text { de } \\
\text { de de dezembro } 1977\end{array}$ & MTE & Geral & $\begin{array}{l}\text { Alterou o Capítulo V, do Título II, da CLT - Consolidação das Leis do } \\
\text { Trabalho, relativo à Segurança e Medicina do Trabalho - artigos 154 a 201. } \\
\text { Cabe ao Ministério do Trabalho a classificação de atividades insalubres, } \\
\text { perigosas, definição de limites de tolerância e de medidas de proteção do } \\
\text { trabalhador, etc. Estipula o valor dos adicionais de insalubridade. }\end{array}$ \\
\hline $\begin{array}{l}\text { Decreto n }{ }^{\circ} \\
83.239, \text { de } 6 \text { de } \\
\text { fevereiro de } \\
1979\end{array}$ & MS & Domissanitários & Regulamenta a Lei nº 6.360, de 23 de setembro de 1976. & BRASIL, 1977. \\
\hline $\begin{array}{l}\text { Decreto n } \\
83.540, \text { de } 04 \text { de } \\
\text { junho de } 1979\end{array}$ & $\begin{array}{l}\text { Marinha, } \\
\text { SEMA, } \\
\text { OEMAs }\end{array}$ & óleo & $\begin{array}{l}\text { Regulamenta a aplicação da Convenção Internacional sobre Responsabilidade } \\
\text { Civil em Danos Causados por Poluição por Óleo, de 1969, }\end{array}$ & BRASIL, 1979. \\
\hline
\end{tabular}

\section{DÉCADA DE 1980}

\begin{tabular}{|l|l|l|l|l|}
\hline $\begin{array}{l}\text { Instrumento } \\
\text { Legal }\end{array}$ & $\begin{array}{l}\text { Órgão(s) } \\
\text { Envolvido(s) } \\
\text { na Aplicação }\end{array}$ & $\begin{array}{l}\text { Substâncias } \\
\text { Químicas } \\
\text { Contempladas }\end{array}$ & Objetivo da Legislação \\
\hline $\begin{array}{l}\text { Portaria } \\
\text { Interministerial } \\
n^{\circ} 19, \text { de } 29 \text { de } \\
\text { janeiro de } 1981\end{array}$ & $\begin{array}{l}\text { MME, MMA, } \\
\text { IBAMA }\end{array}$ & $\begin{array}{l}\text { Bifenil } \\
\text { Policlorados }\end{array}$ & $\begin{array}{l}\text { Proíbe, em todo o território nacional, a implantação de processos que } \\
\text { contenham, como finalidade principal, a produção de Bifenil Policlorados - } \\
\text { PCB. }\end{array}$ \\
\hline $\begin{array}{l}\text { Lei } n^{\circ} \text { 6.938, de } \\
\begin{array}{l}31 \text { de agosto de } \\
1981\end{array}\end{array}$ & SISNAMA & Geral & $\begin{array}{l}\text { Dispõe sobre a Política Nacional de Meio Ambiente, seus fins e mecanismos de } \\
\text { formulação e aplicação; e dá outras providências. }\end{array}$ & BRASIL, 1981. \\
\hline $\begin{array}{l}\text { Portaria } \\
\text { Interministerial } \\
n^{\circ} 3, \text { de 28 de } \\
\text { abril de 1982 }\end{array}$ & MS, MTE & Benzeno & $\begin{array}{l}\text { Proíbe em todo o território nacional a fabricação de produtos que contenham } \\
\text { benzeno em sua composição, admitida, porém, a presença dessa substância } \\
\text { como agente contaminante com porcentual não superior a 1 (um por cento), em } \\
\text { volume. }\end{array}$ & $\begin{array}{l}\text { Estabelece normas para o lançamento de efluentes líquidos contendo } \\
\text { substâncias não-degradáveis de alto grau de toxicidade decorrentes de } \\
\text { quaisquer atividades industriais. Define o que são substâncias não-degradáveis } \\
\text { de alto grau de toxicidade e lista substâncias cujo lançamento é proibido por } \\
\text { serem consideradas cancerígenas }\end{array}$ \\
$\begin{array}{l}\text { Portaria SEMA } \\
157, \text { de 26 de } \\
\text { outubro de 1982 }\end{array}$ & $\begin{array}{l}\text { MINTER } \\
\text { MMA) }\end{array}$ & Várias & & \\
\hline
\end{tabular}




\begin{tabular}{|c|c|c|c|c|}
\hline $\begin{array}{l}\text { Decreto Lei } \mathrm{n}^{\circ} \\
2.063 \text {, de } 6 \text { de } \\
\text { outubro de } 1983\end{array}$ & MT & $\begin{array}{l}\text { Cargas ou produtos } \\
\text { perigosos }\end{array}$ & $\begin{array}{l}\text { Dispõe sobre multas a serem aplicadas por infrações à regulamentação, para a } \\
\text { execução do serviço de transporte rodoviário de cargas ou produtos perigosos. }\end{array}$ & BRASIL, 1983. \\
\hline $\begin{array}{l}\text { Lei } \mathrm{n}^{0} 7.347, \text { de } \\
24 \text { de julho de } \\
1985\end{array}$ & MJ & Geral & $\begin{array}{l}\text { Disciplina a ação civil pública de responsabilidade por danos causados ao meio } \\
\text { ambiente, ao consumidor, a bens e direitos de valor artístico, estético, histórico, } \\
\text { turístico e paisagístico. }\end{array}$ & \\
\hline $\begin{array}{l}\text { Resolução } \\
\text { CONAMA n } 5 \\
\text { de } 20 \text { de } \\
\text { novembro de } \\
1985\end{array}$ & $\begin{array}{l}\text { Órgãos } \\
\text { Estaduais de } \\
\text { Meio } \\
\text { Ambiente }\end{array}$ & $\begin{array}{l}\text { Pentaclorofenol e } \\
\text { pentaclorofenato } \\
\text { de sódio }\end{array}$ & $\begin{array}{l}\text { Condiciona as atividades de transporte, estocagem e uso de pentaclorofenol e } \\
\text { pentaclorofenato de sódio a prévio licenciamento por Órgão Estadual de Meio } \\
\text { Ambiente. }\end{array}$ & CONAMA, 1985. \\
\hline $\begin{array}{l}\text { Resolução } \\
\text { CONAMA no } \\
005, \text { de } 24 \text { de } \\
\text { janeiro de } 1986\end{array}$ & IBAMA & Amianto/asbestos & $\begin{array}{l}\text { Criar uma Comissão Especial para estudar os problemas ambientais } \\
\text { relacionados com a utilização de Amianto ou Asbestos }\end{array}$ & CONAMA, 1986. \\
\hline $\begin{array}{l}\text { Resolução } \\
\text { CONAMA n } 1 \text {, } \\
\text { de } 23 \text { de janeiro } \\
\text { de } 1986\end{array}$ & $\begin{array}{l}\text { Órgãos } \\
\text { Estaduais de } \\
\text { Meio } \\
\text { Ambiente } \\
\end{array}$ & $\begin{array}{l}\text { Atividades } \\
\text { modificadoras do } \\
\text { meio ambiente }\end{array}$ & $\begin{array}{l}\text { Dispõe sobre critérios básicos e diretrizes gerais para o Relatório de Impacto } \\
\text { Ambiental - RIMA. Instituiu a obrigatoriedade da realização de estudos de } \\
\text { impacto ambiental para o licenciamento de atividades modificadoras do meio } \\
\text { ambiente. }\end{array}$ & \\
\hline $\begin{array}{l}\text { Resolução } \\
\text { CONAMA n } \\
14, \text { de } 18 \text { de } \\
\text { março de } 1986\end{array}$ & $\begin{array}{l}\text { Órgãos } \\
\text { Estaduais de } \\
\text { Meio } \\
\text { Ambiente } \\
\end{array}$ & $\begin{array}{l}\text { Pentaclorofenol e } \\
\text { pentaclorofenato } \\
\text { de sódio }\end{array}$ & Referendar a Resolução CONAMA nº 5, de 20/11/1985. & \\
\hline $\begin{array}{l}\text { Resolução } \\
\text { CONAMA nº } \\
20, \text { de } 18 \text { de } \\
\text { junho de } 1986\end{array}$ & MMA & $\begin{array}{l}\text { Poluentes } \\
\text { aquáticos }\end{array}$ & $\begin{array}{l}\text { Estabelece limites máximos aceitáveis de substâncias potencialmente } \\
\text { prejudiciais à qualidade das águas. }\end{array}$ & \\
\hline $\begin{array}{l}\text { Decreto }^{\circ} \\
93.413 \text {, de } 15 \text { de } \\
\text { outubro de } 1986\end{array}$ & - & $\begin{array}{l}\text { Atividades } \\
\text { industriais }\end{array}$ & $\begin{array}{l}\text { Promulga a Convenção n }{ }^{\circ} 148 \text { sobre a Proteção dos Trabalhadores Contra os } \\
\text { Riscos Profissionais Devidos à Contaminação do Ar, ao Ruído e às Vibrações } \\
\text { no Local de Trabalho. Determina aos países da necessidade de elaborar } \\
\text { legislação definindo critérios e limites de exposição dos trabalhadores, medidas } \\
\text { para prevenir e limitar riscos profissionais, etc. Cita que, as atividades com }\end{array}$ & \\
\hline
\end{tabular}




\begin{tabular}{|c|c|c|c|c|}
\hline & & & $\begin{array}{l}\text { substâncias, máquinas ou materiais, que impliquem em exposição dos } \\
\text { trabalhadores aos riscos profissionais devidos à contaminação do ar no local de } \\
\text { trabalho, deverá ser comunicada à autoridade competente, que poderá autorizá- } \\
\text { la ou proibi-la. }\end{array}$ & \\
\hline $\begin{array}{l}\text { Resolução } \\
\text { CONAMA n } 7 \\
\text { de } 18 / 09 / 1987\end{array}$ & $\begin{array}{l}\text { Órgãos de } \\
\text { Meio } \\
\text { Ambiente }\end{array}$ & Amianto/asbestos & \begin{tabular}{|l|} 
Regulamenta o uso de amianto no Brasil. \\
\end{tabular} & CONAMA, 1987. \\
\hline $\begin{array}{l}\text { Decreto } n^{\circ} \\
96.044 \text {, de } 18 \text { de } \\
\text { maio de } 1988\end{array}$ & MT & Produtos perigosos & Aprova o regulamento para o Transporte Rodoviário de Produtos Perigosos. & \\
\hline $\begin{array}{l}\text { Resolução } \\
\text { CONAMA n } 06 \\
\text { de I5 de junho } \\
\text { de } 1988\end{array}$ & IBAMA & $\begin{array}{l}\text { PCBs e outros } \\
\text { resíduos }\end{array}$ & $\begin{array}{l}\text { Instituiu o inventário de resíduos industriais, ressaltando a necessidade de } \\
\text { inventariar resíduos de PCBs. }\end{array}$ & \\
\hline $\begin{array}{l}\text { Decreto } \mathrm{n}^{\circ} \\
97.409, \text { de } 23 \text { de } \\
\text { dezembro de } \\
1988\end{array}$ & MDIC & Geral & \begin{tabular}{|lllll} 
Promulga a Convenção Internacional sobre & Sistema & Harmonizado de \\
Designação e Codificação de Mercadorias. & & & & \\
\end{tabular} & \\
\hline $\begin{array}{l}\text { Decreto } \mathrm{n}^{\circ} \\
97.507, \text { de } 13 \text { de } \\
\text { fevereiro de } \\
1989\end{array}$ & $\begin{array}{l}\text { DNPM, } \\
\text { IBAMA }\end{array}$ & Mercúrio e cianeto & $\begin{array}{l}\text { Dispõe sobre licenciamento de atividade mineral, o uso de mercúrio metálico e } \\
\text { do cianeto em áreas de extração de ouro, e dá outras providências. }\end{array}$ & \\
\hline $\begin{array}{l}\text { Decreto } \mathrm{n}^{\circ} \\
97.634 \text {, de } 10 \text { de } \\
\text { abril de } 1989\end{array}$ & IBAMA & Mercúrio metálico & $\begin{array}{l}\text { Dispõe sobre o controle de produção, importação e comercialização de } \\
\text { mercúrio metálico. Atribui ao IBAMA a responsabilidade pelo cadastramento } \\
\text { de importadores, produtores e comerciantes de mercúrio metálico. }\end{array}$ & BRASIL, 1989. \\
\hline $\begin{array}{l}\text { Decreto } n^{\circ} \\
97.626, \text { de } 10 \text { de } \\
\text { abril de } 1989\end{array}$ & $\begin{array}{l}\text { IBAMA, MS, } \\
\text { MDIC, MET, } \\
\text { MCT, MAPA }\end{array}$ & Todas & $\begin{array}{l}\text { Dispõe sobre a realização de estudos sobre o controle, produção, comércio e } \\
\text { uso de técnicas e métodos, de substâncias químicas que comportem risco para a } \\
\text { vida. }\end{array}$ & \\
\hline $\begin{array}{l}\text { Portaria } \\
\text { Normativa } \mathrm{n}^{\circ} \\
434, \text { de } 9 \text { de } \\
\text { agosto de } 1989 \\
\end{array}$ & IBAMA & Mercúrio metálico & $\begin{array}{l}\text { Implanta o Sistema de Cadastramento e Notificação de pessoas físicas e } \\
\text { jurídicas que importem, produzam e comercializem a substância mercúrio } \\
\text { metálico. }\end{array}$ & \\
\hline
\end{tabular}




\begin{tabular}{|l|l|l|l|l|}
\hline $\begin{array}{l}\text { Portaria } \\
\text { Normativa } \mathrm{n}^{\circ} \\
435-\mathrm{P}, \text { de } 9 \mathrm{de} \\
\text { agosto de } 1989\end{array}$ & IBAMA & Mercúrio metálico & $\begin{array}{l}\text { Implanta o registro obrigatório junto ao Ibama de equipamentos destinados ao } \\
\text { controle do Mercúrio metálico. }\end{array}$ & \\
\hline $\begin{array}{l}\text { Decreto } \\
\text { Legislativo n }\end{array}$ & - & $\begin{array}{l}\text { Substâncias do } \\
\text { Protocolo de } \\
\text { Montreal } 15 \text { de } \\
\text { dezembro de } \\
1989\end{array}$ & $\begin{array}{l}\text { Aprova os textos da Convenção de Viena para a Proteção da Camada de } \\
\text { Ozônio, de 1985, e do Protocolo de Montreal sobre Substâncias que destroem a } \\
\text { Camada de Ozônio, de 1987 }\end{array}$ & \\
\hline
\end{tabular}

\section{DÉCADA DE 1990}

\begin{tabular}{|c|c|c|c|c|}
\hline $\begin{array}{l}\text { Instrumento } \\
\text { Legal }\end{array}$ & $\begin{array}{l}\text { Órgão(s) } \\
\text { Envolvido(s) } \\
\text { na Aplicação }\end{array}$ & $\begin{array}{l}\text { Substâncias } \\
\text { Químicas } \\
\text { Contempladas }\end{array}$ & Objetivo da Legislação & Competência - Referência \\
\hline $\begin{array}{l}\text { Decreto } n^{\circ} \\
98.973 \text {, de } 21 \text { de } \\
\text { fevereiro de } \\
1990\end{array}$ & MT & $\begin{array}{l}\text { Produtos perigosos } \\
\text { - transporte }\end{array}$ & $\begin{array}{l}\text { Dispõe sobre o Regulamento do Transporte Ferroviário de Produtos Perigosos, } \\
\text { no qual são definidas as normas para a classificação, a identificação e a } \\
\text { rotulagem para o transporte ferroviário de produtos químicos. }\end{array}$ & \\
\hline $\begin{array}{l}\text { Decreto } \mathrm{n}^{\mathrm{O}} \\
99.274 \text {, de } 6 \text { de } \\
\text { junho de } 1990\end{array}$ & SISNAMA & Todas & $\begin{array}{l}\text { Regulamenta a a Lei n }{ }^{\circ} 6.938 \text {, de } 31 \text { de agosto de 1981, Política Nacional do } \\
\text { Meio Ambiente e a Lei n }{ }^{\circ} 6.902 \text {, de } 27 \text { de abril de 1981, que dispõe sobre a } \\
\text { criação de Estações Ecológicas e Áreas de Proteção Ambiental. }\end{array}$ & \\
\hline $\begin{array}{l}\text { Decreto } \mathrm{n}^{\circ} \\
99.280 \text {, de } 06 \text { de } \\
\text { junho de } 1990\end{array}$ & - & $\begin{array}{l}\text { Substâncias do } \\
\text { Protocolo de } \\
\text { Montreal }\end{array}$ & $\begin{array}{l}\text { Promulgação da Convenção de Viena para a Proteção da Camada de Ozônio e } \\
\text { do Protocolo de Montreal sobre Substâncias que Destroem a Camada de Ozônio }\end{array}$ & \\
\hline $\begin{array}{l}\text { Lei } \mathrm{n}^{\circ} 8.078, \text { de } \\
11 \text { de setembro } \\
\text { de } 1990\end{array}$ & MJ & $\begin{array}{l}\text { Geral - defesa do } \\
\text { consumidor }\end{array}$ & $\begin{array}{l}\text { Código de Defesa do Consumidor. Dispõe sobre a proteção do consumidor e dá } \\
\text { outras providências. Impõe restrições às propagandas referentes à produtos que } \\
\text { podem que possam ser nocivos à saúde e ao meio ambiente, como o tabaco, as } \\
\text { bebidas alcoólicas, os agrotóxicos etc. }\end{array}$ & \\
\hline $\begin{array}{l}\text { Lei } 8.080 \text { de } 20 \\
\text { de setembro de } \\
1990\end{array}$ & MS & Geral & $\begin{array}{l}\text { Lei Orgânica da Saúde. Dispõe sobre as condições para a promoção, proteção e } \\
\text { recuperação da saúde, a organização e o funcionamento dos serviços } \\
\text { correspondentes e dá outras providências. }\end{array}$ & \\
\hline $\begin{array}{l}\text { Resolução } \\
\text { CONAMA n } 6 \\
\text { de } 17 \text { de outubro } \\
\text { de } 1990\end{array}$ & $\begin{array}{l}\text { Órgãos de } \\
\text { Meio } \\
\text { Ambiente }\end{array}$ & $\begin{array}{l}\text { Dispersantes de } \\
\text { petróleo }\end{array}$ & $\begin{array}{l}\text { Regulamenta a aplicação de dispersantes químicos em vazamentos, derrames e } \\
\text { descargas de petróleo e seus derivados. }\end{array}$ & \\
\hline
\end{tabular}




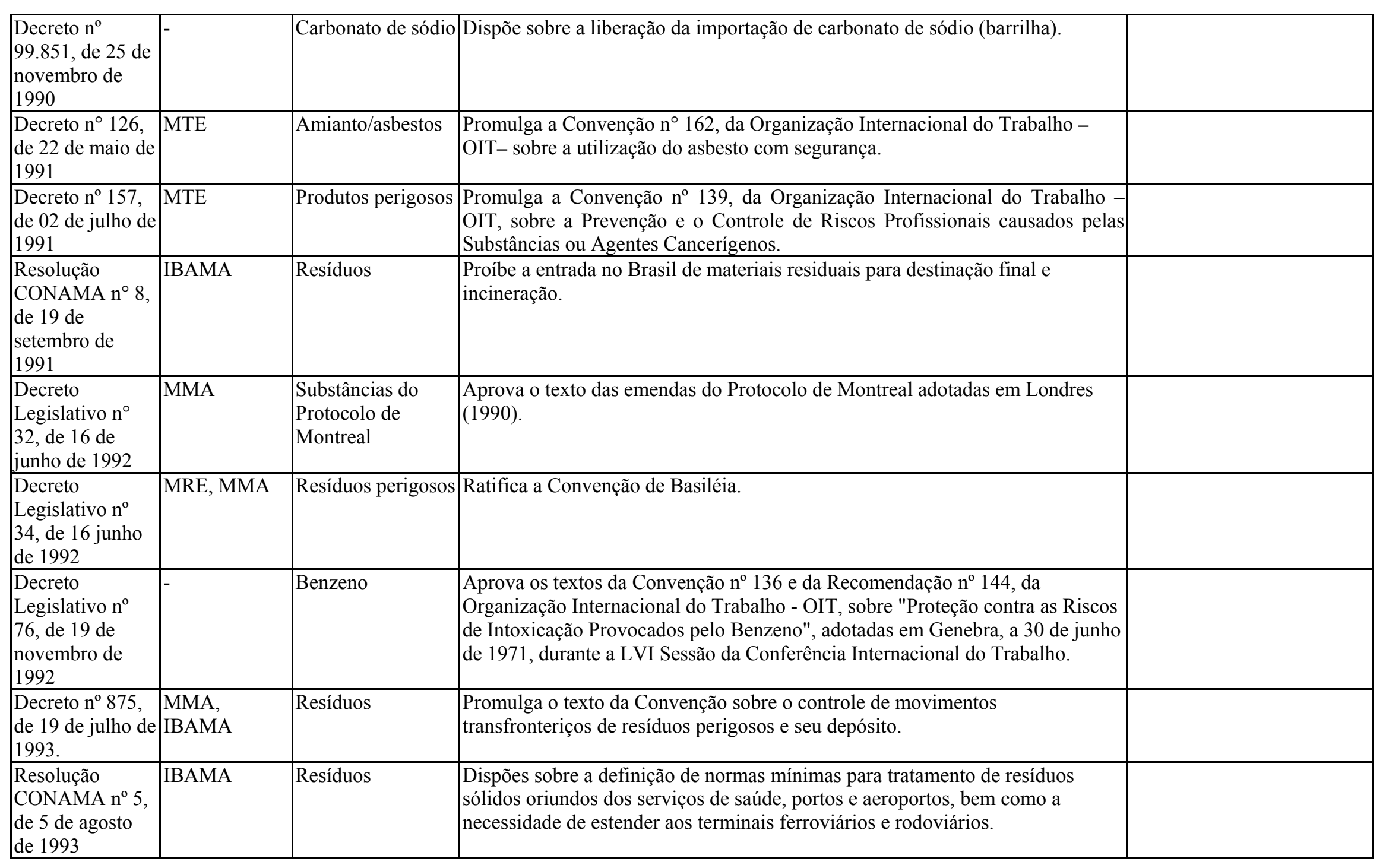




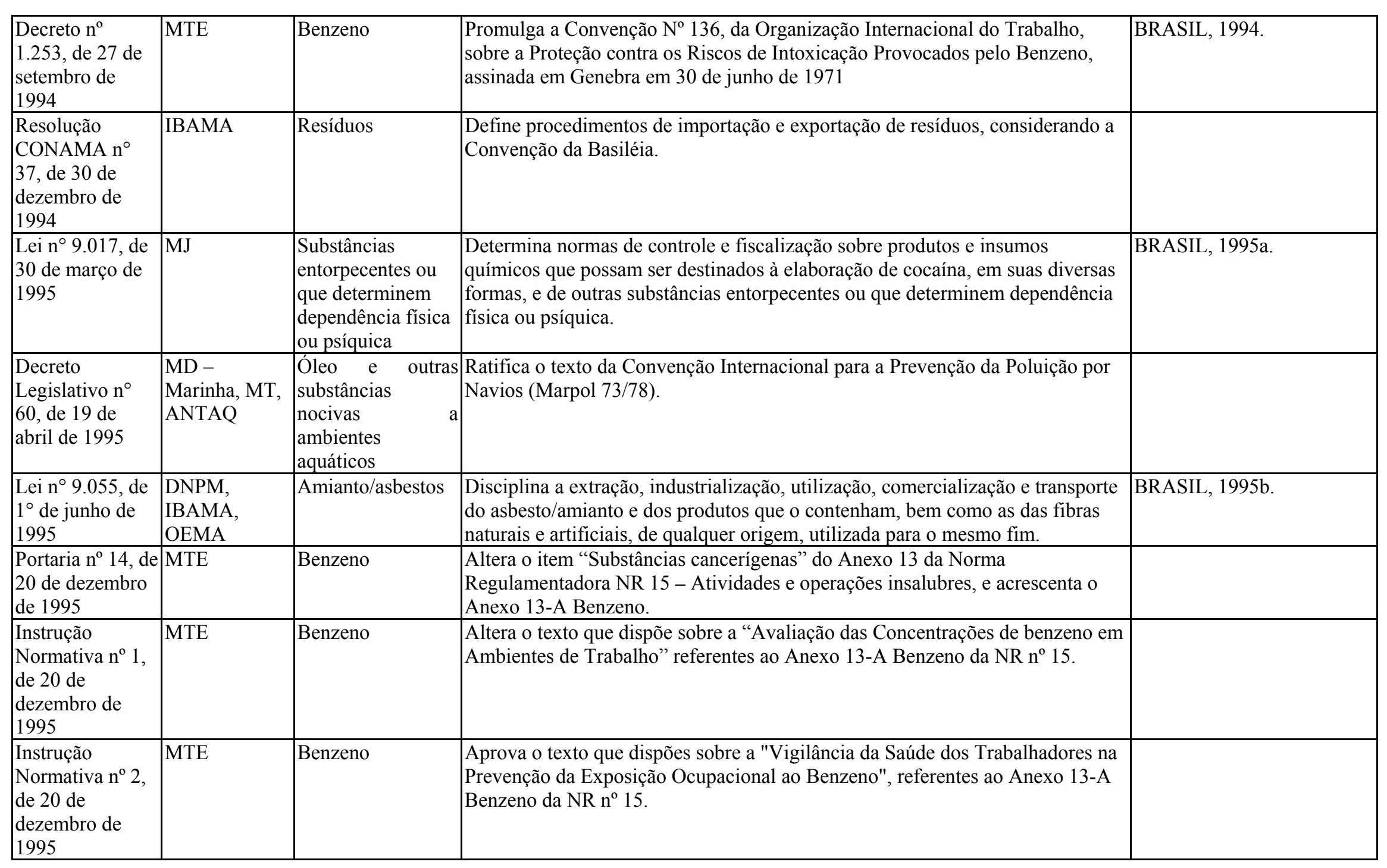




\begin{tabular}{|c|c|c|c|c|}
\hline $\begin{array}{l}\text { Decreto } \mathrm{n}^{\circ} \\
1.797, \text { de } 25 \text { de } \\
\text { janeiro de } 1996\end{array}$ & $\begin{array}{l}\text { MD - } \\
\text { Exército, } \\
\text { MRE, MT }\end{array}$ & Produtos perigosos & $\begin{array}{l}\text { Dispõe sobre a execução do Acordo de Alcance Parcial para a Facilitação do } \\
\text { Transporte de Produtos Perigosos entre Brasil, Argentina, Paraguai e Uruguai, } \\
\text { de } 30 \text { de dezembro de } 1994 \text {. }\end{array}$ & \\
\hline $\begin{array}{l}\text { Resolução } \\
\text { CONAMA n } \\
19, \text { de } 24 \text { de } \\
\text { outubro de } 1996\end{array}$ & $\begin{array}{l}\text { Órgãos de } \\
\text { Meio } \\
\text { Ambiente }\end{array}$ & Amianto/asbestos & $\begin{array}{l}\text { Estabelece critérios de impressão de legenda em peças que contêm amianto } \\
\text { (asbestos). }\end{array}$ & CONAMA, 1996. \\
\hline $\begin{array}{l}\text { Resolução } \\
\text { CONAMA n } \\
23, \text { de } 12 \text { de } \\
\text { dezembro de } \\
1996\end{array}$ & IBAMA & Resíduos perigosos & $\begin{array}{l}\text { Complementada pela Resolução }{ }^{0} \text { 235/97, que dispõe sobre a classificação de } \\
\text { resíduos e proibição da importação daqueles considerados perigosos. }\end{array}$ & \\
\hline $\begin{array}{l}\text { Resolução } \\
\text { CONAMA n } \\
235, \text { de } 7 \text { de } \\
\text { janeiro de } 1997\end{array}$ & IBAMA & Resíduos perigosos & Altera o anexo 10 da Resolução n 23/1996, sobre resíduos perigosos. & \\
\hline $\begin{array}{l}\text { Resolução } \\
\text { CONAMA n } \\
228, \text { de } 20 \text { de } \\
\text { agosto de } 1997\end{array}$ & IBAMA & Metais pesados & $\begin{array}{l}\text { Dispõe sobre a importação de sucatas e resíduos de acumuladores elétricos de } \\
\text { chumbo. }\end{array}$ & \\
\hline $\begin{array}{l}\text { Decreto } \mathrm{n}^{\circ} \\
2.350, \text { de } 15 \text { de } \\
\text { outubro de } 1997 .\end{array}$ & $\begin{array}{l}\text { DNPM, } \\
\text { IBAMA }\end{array}$ & Amianto/asbestos & Regulamenta a Lei ${ }^{\circ} 9.055$, de $1^{\circ}$ de junho de 1995 sobre amianto/asbestos. & \\
\hline $\begin{array}{l}\text { Resolução } \\
\text { CONAMA n } \\
237, \text { de } 19 \text { de } \\
\text { dezembro de } \\
1997\end{array}$ & $\begin{array}{l}\text { Órgãos de } \\
\text { Meio } \\
\text { Ambiente }\end{array}$ & Geral & $\begin{array}{l}\text { Determina a necessidade de prévio licenciamento ambiental no órgão federal } \\
\text { competente para a localização, construção, instalação, ampliação, modificação e } \\
\text { operação de empreendimentos e atividades utilizadoras de recursos ambientais, } \\
\text { incluindo a indústria de produtos minerais não metálicos, a indústria química e } \\
\text { o transporte de produtos perigosos. }\end{array}$ & \\
\hline $\begin{array}{l}\text { Lei }{ }^{\circ} 9.605, \text { de } \\
12 \text { de fevereiro } \\
\text { de } 1998\end{array}$ & $\begin{array}{l}\text { Órgãos de } \\
\text { Meio } \\
\text { Ambiente } \\
\end{array}$ & $\begin{array}{l}\text { Geral - crimes } \\
\text { ambientais }\end{array}$ & $\begin{array}{l}\text { Lei de Crimes Ambientais. Dispõe sobre as sanções penais e administrativas } \\
\text { derivadas de condutas e atividades lesivas ao meio ambiente. }\end{array}$ & BRASIL, 1998. \\
\hline $\begin{array}{l}\text { Decreto } \mathrm{n}^{\circ} \\
2.508, \text { de } 4 \text { de } \\
\text { fevereiro de } \\
1998 .\end{array}$ & $\begin{array}{l}\text { MD-Marinha, } \\
\text { MT/ANTAQ }\end{array}$ & $\begin{array}{l}\text { Poluentes } \\
\text { marinhos }\end{array}$ & $\begin{array}{l}\text { Ratifica a Convenção Internacional para a Prevenção da Poluição Causada por } \\
\text { Navios, Londres, em } 2 \text { de novembro de 1973, seu Protocolo, concluído em } \\
\text { Londres, em } 17 \text { de fevereiro de 1978, suas Emendas de } 1984 \text { e seus Anexos } \\
\text { Opcionais III, IV e V. }\end{array}$ & \\
\hline
\end{tabular}




\begin{tabular}{|c|c|c|c|c|}
\hline $\begin{array}{l}\text { Decreto } n^{\circ} \\
2.657 \text {, de } 3 \text { de } \\
\text { julho de } 1998\end{array}$ & MTE & Todas & $\begin{array}{l}\text { Promulga a Convenção n }{ }^{\circ} 170 \text { da OIT, relativa à Segurança na Utilização de } \\
\text { Produtos Químicos no Trabalho, assinada em Genebra, em } 25 \text { de junho de } \\
1990 .\end{array}$ & \\
\hline $\begin{array}{l}\text { Decreto } \mathrm{n}^{\circ} \\
2.699, \text { de } 30 \text { de } \\
\text { julho de } 1998\end{array}$ & MMA & $\begin{array}{l}\text { Substâncias do } \\
\text { Protocolo de } \\
\text { Montreal }\end{array}$ & $\begin{array}{l}\text { Promulga a Emenda ao Protocolo de Montreal sobre Substâncias que destroem } \\
\text { a Camada de Ozônio, assinada em Londres, em } 29 \text { de junho de } 1990 .\end{array}$ & \\
\hline $\begin{array}{l}\text { Decreto } \mathrm{n}^{\circ} \\
2.866, \text { de } 7 \text { de } \\
\text { dezembro de } \\
1998\end{array}$ & MT, MRE & Produtos perigosos & $\begin{array}{l}\text { Dispõe sobre a execução do Primeiro Protocolo Adicional ao Acordo de } \\
\text { Alcance parcial para a Facilitação do Transporte de Produtos Perigosos, } \\
\text { firmado em } 16 \text { de julho de1998, entre os Governos do Brasil, Argentina, } \\
\text { Paraguai e do Uruguai. }\end{array}$ & \\
\hline $\begin{array}{l}\text { Decreto } \mathrm{n}^{\mathrm{o}} \\
2.870, \text { de } 10 \text { de } \\
\text { dezembro de } \\
1998\end{array}$ & - & óleo & $\begin{array}{l}\text { Promulga a Convenção Internacional sobre Preparo, Resposta e Cooperação em } \\
\text { Caso de Poluição por Óleo, assinada em Londres, em } 30 \text { de novembro de } 1990 .\end{array}$ & \\
\hline $\begin{array}{l}\text { Decreto } \mathrm{n}^{\circ} \\
3.048 \text {, de } 6 \text { de } \\
\text { maio de } 1999 .\end{array}$ & MS & Domissanitários & $\begin{array}{l}\text { Aprova o Regulamento da Previdência Social e, especialmente, Anexo IV, que } \\
\text { determina a classificação e o tempo de exposição aos agentes nocivos, então } \\
\text { inclusos o arsênio e seus compostos, asbestos, benzeno, berílio, bromo, cádmio, } \\
\text { chumbo, cloro, cromo, dissulfeto de carbono, fósforo, iodo, manganês, } \\
\text { mercúrio, níquel, sílica e outras substâncias químicas preocupantes para a saúde } \\
\text { do trabalhador. }\end{array}$ & \\
\hline $\begin{array}{l}\text { Resolução } \\
\text { CONAMA n } \\
\text { 257, de } 30 \text { de } \\
\text { junho de } 1999\end{array}$ & $\begin{array}{l}\text { Órgãos de } \\
\text { Meio } \\
\text { Ambiente }\end{array}$ & Metais pesados & $\begin{array}{l}\text { Estabelece os procedimentos de reutilização, reciclagem, tratamento ou } \\
\text { disposição final de pilhas e baterias, que contenham em suas composições } \\
\text { chumbo, cádmio, mercúrio e seus compostos. }\end{array}$ & \\
\hline $\begin{array}{l}\text { Resolução } \mathrm{n}^{0} \\
364 \text {, de } 29 \text { de } \\
\text { julho de } 1999\end{array}$ & ANVISA & PCBS e Dioxinas & $\begin{array}{l}\text { Revogada pela Resolução RDC } \mathrm{n}^{\circ} 15 \text {, de } 05 \text { de novembro de } 1999 \text {. Exigia o } \\
\text { Certificado Sanitário Oficial e a Declaração, para importação de alimentos } \\
\text { industrializados de origem belga que tenham na sua composição carne bovina, } \\
\text { carne suína, carne de aves, ovos, leite e derivados destes produtos, produzidos a } \\
\text { partir de } 15 \text { de janeiro de 1999. Apresentação de laudo de análise do produto, } \\
\text { que comprove a não contaminação com dioxina, considerando o PCB (bifenilas } \\
\text { policloradas) como indicador para dioxina em produtos de origem animal. }\end{array}$ & \\
\hline $\begin{array}{l}\text { Resolução } \\
\text { CONAMA n } \\
\text { 264, de } 26 \text { de } \\
\text { agosto de } 1999\end{array}$ & $\begin{array}{l}\text { Órgãos de } \\
\text { Meio } \\
\text { Ambiente }\end{array}$ & Resíduos perigosos & $\begin{array}{l}\text { Determina procedimentos para o licenciamento de fornos rotativos de produção } \\
\text { de clínquer para atividades de co-processamento de resíduos. }\end{array}$ & \\
\hline Decreto $\mathrm{n}^{\circ}$ & Órgãos de & Geral & Regulamenta a lei de crimes ambientais n ${ }^{\circ} 9.605$, de 12 de fevereiro de1998. & BRASIL, 1999. \\
\hline
\end{tabular}




\begin{tabular}{|l|l|l|l|l|}
\hline $\begin{array}{l}3.179, \text { de } 21 \text { de } \\
\text { setembro de }\end{array}$ & $\begin{array}{l}\text { Meio } \\
\text { Ambiente }\end{array}$ & & & \\
1999 & & & \\
\hline
\end{tabular}

PERÍODO DE 2000 - 2004

\begin{tabular}{|c|c|c|c|c|}
\hline $\begin{array}{l}\text { Instrumento } \\
\text { Legal }\end{array}$ & $\begin{array}{l}\text { Órgão(s) } \\
\text { Envolvido(s) } \\
\text { na Aplicação }\end{array}$ & $\begin{array}{l}\text { Substâncias } \\
\text { Químicas } \\
\text { Contempladas }\end{array}$ & Objetivo da Legislação & Competência - Referência \\
\hline $\begin{array}{l}\text { Lei } \mathrm{n}^{\circ} 9.966, \text { de } \\
29 \text { de abril de } \\
2000\end{array}$ & $\begin{array}{l}\text { MMA, MT, } \\
\text { MD - Marinha }\end{array}$ & $\begin{array}{l}\text { Óleo e outras } \\
\text { substâncias } \\
\text { (ambientes } \\
\text { aquáticos) }\end{array}$ & $\begin{array}{l}\text { Dispõe sobre a prevenção, o controle e a fiscalização da poluição causada por } \\
\text { lançamento de óleo e outras substâncias (nocivas ou perigosas) em águas sob } \\
\text { jurisdição nacional e dá outras providências. }\end{array}$ & \\
\hline $\begin{array}{l}\text { Resolução RDC } \\
n^{\circ} 19, \text { de } 03 \text { de } \\
\text { março de } 2000\end{array}$ & ANVISA & Brometo de Metila & $\begin{array}{l}\text { (Revogada pela Resolução RDC n }{ }^{0} 252 \text {, de } 11 \text { de setembro de 2002) } \\
\text { Próbe a utilização do Brometo de Metila no tratamento de madeiras em todo } \\
\text { território nacional }\end{array}$ & \\
\hline $\begin{array}{l}\text { Lei } \mathrm{n}^{\circ} 9.976, \text { de } \\
3 \text { de julho de } \\
2000\end{array}$ & MS, MMA & Cloro & $\begin{array}{l}\text { Dispõe sobre a produção de cloro e dá outras providências. Institui o sistema } \\
\text { gerencial de controle do amianto, nas indústrias e a discussão dos riscos para a } \\
\text { saúde e para o meio ambiente em decorrência do uso do mercúrio e do amianto, } \\
\text { no âmbito das CIPAs. }\end{array}$ & \\
\hline $\begin{array}{l}\text { Resolução } \\
\text { CONAMA n } \\
267, \text { de } 14 \text { de } \\
\text { setembro de } \\
2000\end{array}$ & $\begin{array}{l}\text { Órgãos de } \\
\text { Meio } \\
\text { Ambiente }\end{array}$ & $\begin{array}{l}\text { Substâncias do } \\
\text { Protocolo de } \\
\text { Montreal }\end{array}$ & Proíbe o uso de substâncias controladas que destroem a Camada de Ozônio. & \\
\hline $\begin{array}{l}\text { Decreto } \mathrm{n}^{\circ} \\
3.665, \text { de } 20 \text { de } \\
\text { novembro de } \\
2000\end{array}$ & MD - Exército & $\begin{array}{l}\text { Substâncias } \\
\text { explosivas }\end{array}$ & $\begin{array}{l}\text { Dá nova redação ao Regulamento para a Fiscalização de Produtos Controlados } \\
\text { (R-105). }\end{array}$ & \\
\hline $\begin{array}{l}\text { Lei } \mathrm{n}^{\circ} 10.165 \text { de } \\
27 \text { de dezembro }\end{array}$ & MMA & Geral & $\begin{array}{l}\text { Modifica a Lei } \mathrm{n}^{\circ} \text { 6.938, de } 31 \text { de agosto de } 1981 \text { - Política Nacional de Meio } \\
\text { Ambiente. Institui a Taxa de Controle e Fiscalização Ambiental - TCFA, }\end{array}$ & BRASIL, 2000a. \\
\hline
\end{tabular}




\begin{tabular}{|c|c|c|c|c|}
\hline de 2000 & & & $\begin{array}{l}\text { apresenta atividades passíveis de fiscalização e fixa escalas de potencial de } \\
\text { poluição (PP) e o grau de utilização (GU) de recursos naturais. }\end{array}$ & \\
\hline $\begin{array}{l}\text { Resolução RE n } \\
528 \text {, de } 17 \text { de } \\
\text { abril de } 2001\end{array}$ & ANVISA/MS & Mercúrio & Proibi o uso de compostos mercuriais nos medicamentos. & \\
\hline $\begin{array}{l}\text { Resolução } \\
\text { CONAMA n } \\
283, \text { de } 12 \text { de } \\
\text { setembro de } \\
2001\end{array}$ & IBAMA & Resíduos & Dispõe sobre o tratamento e disposição final dos resíduos de serviços de saúde. & \\
\hline $\begin{array}{l}\text { Lei } n^{\circ} 10.357 \text {, de } \\
27 \text { de dezembro } \\
\text { de } 2001 .\end{array}$ & $\mathrm{MJ}, \mathrm{MS}$ & $\begin{array}{l}\text { Substâncias } \\
\text { entorpecentes ou } \\
\text { que determinem } \\
\text { dependência física } \\
\text { ou psíquica }\end{array}$ & $\begin{array}{l}\text { Estabelece normas de controle e fiscalização sobre produtos químicos que } \\
\text { direta ou indiretamente possam ser destinados à elaboração ilícita de } \\
\text { substâncias entorpecentes, psicotrópicas ou que determinem dependência física } \\
\text { ou psíquica, e dá outras providências. }\end{array}$ & \\
\hline $\begin{array}{l}\text { Lei } \mathrm{n}^{\circ} 10.409, \text { de } \\
11 \text { de janeiro de } \\
2002\end{array}$ & $\mathrm{MS}, \mathrm{MJ}$ & $\begin{array}{l}\text { Substâncias } \\
\text { entorpecentes ou } \\
\text { que determinem } \\
\text { dependência física } \\
\text { ou psíquica } \\
\end{array}$ & $\begin{array}{l}\text { Dispõe sobre a prevenção, o tratamento, a físcalização, o controle e a repressão } \\
\text { à produção, ao uso e ao tráfico ilícitos de produtos, substâncias ou drogas } \\
\text { ilícitas que causem dependência física ou psíquica, assim descritos pelo } \\
\text { Ministério da Saúde, e dá outras providências. }\end{array}$ & \\
\hline $\begin{array}{l}\text { Decreto } \mathrm{n}^{\circ} \\
4.085 \text {, de } 15 \text { de } \\
\text { janeiro de } 2002\end{array}$ & MTE & Todas & $\begin{array}{l}\text { Promulga a Convenção n } 174 \text { da OIT e a Recomendação nº } 181 \text { sobre a } \\
\text { Prevenção de Acidentes Industriais Maiores. }\end{array}$ & \\
\hline $\begin{array}{l}\text { Decreto } \mathrm{n}^{\circ} \\
4.097, \text { de } 23 \text { de } \\
\text { janeiro de } 2002\end{array}$ & MT & Produtos perigosos & $\begin{array}{l}\text { Altera a redação dos itens } 7^{\circ} \text { e } 19^{\circ} \text { dos Regulamentos para transporte rodoviário } \\
\text { e ferroviário de produtos perigosos. }\end{array}$ & \\
\hline $\begin{array}{l}\text { Decreto } \mathrm{n}^{\circ} \\
4.136, \text { de } 20 \text { de } \\
\text { fevereiro de } \\
2002\end{array}$ & $\begin{array}{l}\text { MD - } \\
\text { Marinha, MT, } \\
\text { ANTAQ, } \\
\text { órgãos de meio } \\
\text { ambiente } \\
\end{array}$ & $\begin{array}{ll}\text { Óleos } & \text { e } \\
\text { substâncias } & \\
\text { nocivas } & \text { a } \\
\text { ambientes } & \\
\text { aquáticos } & \\
\end{array}$ & $\begin{array}{l}\text { Dispõe sobre a especificação das sanções aplicáveis às infrações às regras de } \\
\text { prevenção, controle e fiscalização da poluição causada por lançamento de óleo } \\
\text { e outras substâncias nocivas ou perigosas em águas sob jurisdição nacional, } \\
\text { prevista na Lei }{ }^{\circ} 9.966 \text {, de } 28 \text { de abril de } 2000 \text {. }\end{array}$ & \\
\hline $\begin{array}{l}\text { Decreto } \mathrm{n}^{\circ} \\
4.262, \text { de } 10 \text { de } \\
\text { junho de } 2002\end{array}$ & MJ, MS & $\begin{array}{l}\text { Substâncias } \\
\text { entorpecentes ou } \\
\text { que determinem } \\
\text { dependência física } \\
\text { ou psíquica }\end{array}$ & Regulamenta a Lei $\mathrm{n}^{\circ} 10.357$, de 27 de dezembro de 2001 . & \\
\hline
\end{tabular}




\begin{tabular}{|c|c|c|c|c|}
\hline $\begin{array}{l}\text { Instrução } \\
\text { Normativa } n^{\circ} 45 \text {, } \\
\text { de } 24 \text { de julho de } \\
2002\end{array}$ & $\begin{array}{l}\text { MAPA, } \\
\text { IBAMA e } \\
\text { ANVISA }\end{array}$ & Brometo de Metila & $\begin{array}{l}\text { Termo Ajustamento de Conduta - SDA - ANVISA - IBAMA. } \\
\text { Manter os usos autorizados do Brometo de Metila para procedimentos } \\
\text { fitossanitários, quarentenários e de pré-embarque. }\end{array}$ & \\
\hline $\begin{array}{l}\text { Resolução } \\
\text { CONAMA n } \\
316, \text { de } 29 \text { de } \\
\text { setembro de } \\
2002\end{array}$ & $\begin{array}{l}\text { Órgãos de } \\
\text { Meio } \\
\text { Ambiente }\end{array}$ & Resíduos & $\begin{array}{l}\text { Estabelece os procedimentos e os critérios para o funcionamento de sistemas de } \\
\text { tratamento térmico de resíduos. }\end{array}$ & \\
\hline $\begin{array}{l}\text { Instrução } \\
\text { Normativa } \\
\text { Conjunta } \mathrm{n}^{\mathrm{o}} 1 \text {, de } \\
10 \text { de setembro } \\
\text { de } 2002\end{array}$ & $\begin{array}{l}\text { MAPA, } \\
\text { IBAMA e } \\
\text { ANVISA } \\
\end{array}$ & Brometo de Metila & $\begin{array}{l}\text { Proibir o uso do Brometo de Metila para expurgos em cereais e grãos } \\
\text { armazenados e no tratamento pós-colheita das culturas }\end{array}$ & \\
\hline $\begin{array}{l}\text { Lei } \mathrm{n}^{\mathrm{o}} 10.650, \text { de } \\
16 \text { de abril de } \\
2003\end{array}$ & SISNAMA & Geral & $\begin{array}{l}\text { Obriga as instituições públicas integrantes do SISNAMA a fornecerem todas as } \\
\text { informações ambientais que estejam sob sua guarda. }\end{array}$ & \\
\hline
\end{tabular}


TABELA 6. Legislação Federal Relacionada a Agrotóxicos

\begin{tabular}{|c|c|c|c|c|}
\hline $\begin{array}{c}\text { Instrumento } \\
\text { Legal }\end{array}$ & $\begin{array}{c}\text { Órgão(s) } \\
\text { Envolvido(s) na } \\
\text { Aplicação } \\
\end{array}$ & $\begin{array}{c}\text { Substâncias } \\
\text { Químicas envolvidas }\end{array}$ & Objetivo da Legislação & Referência \\
\hline $\begin{array}{ll}\text { Decreto } & \mathrm{n}^{\mathrm{o}} \\
15.198, & \mathrm{de} \\
21 / 12 / 1921 & \end{array}$ & MAPA & Agrotóxicos & Regulamento de Defesa Sanitária Vegetal & TOMITA, 2004 \\
\hline $\begin{array}{ll}\text { Decreto } & \mathrm{n}^{\mathrm{o}} \\
24.114, & \mathrm{de} \\
12 / 04 / 1934 & \end{array}$ & MAPA & Agrotóxicos & $\begin{array}{l}\text { Novo Regulamento de Defesa Sanitária Vegetal. Definiu os procedimentos } \\
\text { necessários e obrigatórios para evitar a disseminação de pragas e doenças } \\
\text { decorrentes do trânsito de produtos vegetais no país, incluindo a sua } \\
\text { exportação. Cita a necessidade do uso de produtos agrotóxicos para } \\
\text { combater pragas e doenças, desde que autorizado pelo Ministério da } \\
\text { Agricultura. }\end{array}$ & BRASIL, 1934b. \\
\hline 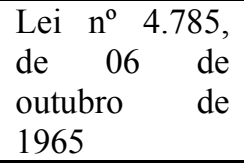 & MAPA & Agrotóxicos & $\begin{array}{l}\text { Dispõe sobre a fiscalização do comércio e uso de produtos Fitossanitários e } \\
\text { da outras providências. Definiu produtos fitossanitários }\end{array}$ & BRASIL, $1965 b$. \\
\hline 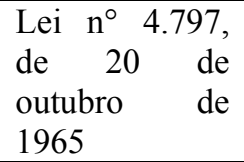 & IBAMA & Madeiras preservadas & $\begin{array}{l}\text { Determina como obrigatório o emprego de madeiras preservadas, } \\
\text { especialmente preparadas e trabalhadas para esse fim em serviços de } \\
\text { utilidade pública. }\end{array}$ & BRASIL, $1965 \mathrm{c}$. \\
\hline $\begin{array}{ll}\text { Decreto } & \mathrm{n}^{\circ} \\
58.016 \text {, de } & 18 \\
\text { de março de } & \text { de } \\
1966 & \end{array}$ & MAPA & Madeiras preservadas & Regulamenta o disposto na Lei No 4.797, de 20 de outubro de 1965. & BRASIL, 1966. \\
\hline $\begin{array}{ll}\text { Decreto } & \mathrm{n}^{\mathrm{o}} \\
67.112, & \mathrm{de} \\
26 / 08 / 1970 & \end{array}$ & MS & Saúde pública & $\begin{array}{l}\text { Aprova normas tecnicas especiais para controle da fabricação e venda de } \\
\text { produtos saneantes e congeneres. }\end{array}$ & TOMITA, 2004. \\
\hline $\begin{array}{ll}\text { Portaria } & n^{\circ} \\
356, & \text { de } \\
15 / 10 / 1971\end{array}$ & MAPA & DDT e BHC & $\begin{array}{l}\text { Proíbe a fabricação e a comercialização dos produtos para combater } \\
\text { ectoparasitas em animais domésticos. }\end{array}$ & $\begin{array}{l}\text { D'AMATO et al., } \\
2002 .\end{array}$ \\
\hline $\begin{array}{ll}\text { Portaria } & n^{\circ} \\
357, & \text { de } \\
15 / 10 / 1971 . & \\
\end{array}$ & MAPA & Organoclorados & Próibe o uso de organoclorados em pastagens & $\begin{array}{l}\text { D'AMATO et al. } \\
2002 \text { e TOMITA, } \\
2004\end{array}$ \\
\hline
\end{tabular}




\begin{tabular}{|c|c|c|c|c|}
\hline $\begin{array}{l}\text { Instrumento } \\
\text { Legal }\end{array}$ & $\begin{array}{c}\text { Órgão(s) } \\
\text { Envolvido(s) na } \\
\text { Aplicação } \\
\end{array}$ & $\begin{array}{c}\text { Substâncias } \\
\text { Químicas envolvidas }\end{array}$ & Objetivo da Legislação & Referência \\
\hline $\begin{array}{ll}\text { Portaria } & \mathrm{n}^{\circ} \\
393, & \mathrm{de} \\
05 / 10 / 1972\end{array}$ & MAPA & Organoclorados & Pró́be o uso de organoclorados na cultura de fumo & TOMITA, 2004 \\
\hline $\begin{array}{ll}\text { Portaria } & \mathrm{n}^{\mathrm{o}} \\
326, & \mathrm{de} \\
16 / 08 / 1974 & \end{array}$ & MAPA & $2,4,5 \mathrm{~T}$ & $\begin{array}{l}\text { Proíbe o uso do 2,4,5 T em florestas e margens de riso, lagos,açudes, poços } \\
\text { e manaciais. }\end{array}$ & TOMITA, 2004 \\
\hline $\begin{array}{l}\text { Portaria } 002 \\
\text { de } 06 / 01 / 1975\end{array}$ & MAPA & Mercuriais & Proíbe o uso de composto mercuriais na agricultura & TOMITA, 2004 \\
\hline 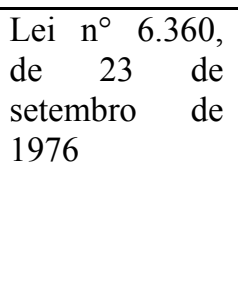 & MS & $\begin{array}{l}\text { Produtos saneantes, } \\
\text { inseticidas, } \\
\text { domissanitários, } \\
\text { raticidas, } \\
\text { desinfetantes } \\
\text { detergentes. }\end{array}$ & $\begin{array}{l}\text { Dispõe sobre a vigilância sanitária a que ficam sujeitos produtos saneantes } \\
\text { domissanitários, inseticidas, raticidas, desinfetantes, detergentes. A } \\
\text { extração, produção, fabricação, transformação, síntese, purificação, } \\
\text { embalagem, reembalagem, importação ou expedição desses produtos pelas } \\
\text { empresas devem ser autorizadas pelo Ministério da Saúde e licenciadas } \\
\text { pelos órgãos sanitários estaduais. São definidos os conteúdos de rótulos, } \\
\text { registros e os respectivos controles. }\end{array}$ & BRASIL, 1976. \\
\hline $\begin{array}{l}\text { Portaria } \mathrm{n}^{\circ} 220 \\
\text { de } 14 \text { março de } \\
1979 .\end{array}$ & MAPA & Agrotóxicos & Disciplina rotulagens de defensivos agrícolas. & GARCIA, 2001. \\
\hline $\begin{array}{l}\text { Portaria } \\
\text { DISAD n } \mathrm{n}^{\circ} \text {, } \\
\text { de } 30 \text { de abril } \\
\text { de } 1980\end{array}$ & MS & Agrotóxicos & $\begin{array}{l}\text { Estabelece normas para a classificação toxicológica de defensivos } \\
\text { agrícolas. }\end{array}$ & GARCIA, 2001. \\
\hline $\begin{array}{l}\text { Portaria } \\
\text { DISAD n } 5 \\
\text { de } 30 \text { de abril } \\
\text { de } 1980\end{array}$ & MS & Agrotóxicos & & \\
\hline $\begin{array}{l}\text { Portaria 25, de } \\
21 / 09 / 1981 .\end{array}$ & MAPA & Sementes & $\begin{array}{l}\text { Estabelece que todo o defensivo agrícola destinado ao tratamento de } \\
\text { sementes seja obrigatoriamente acrescido de corante, a fim de o diferenciar } \\
\text { do produto não-tratado. }\end{array}$ & MAPA, 1981a \\
\hline $\begin{array}{l}\text { Portaria 22, de } \\
17 / 08 / 1981 \text {. }\end{array}$ & MAPA & Sementes & $\begin{array}{l}\text { Estabelece que todo produto defensivo agrícola destinado ao tratamento de } \\
\text { sementes para plantio, seja obrigatoriamente acrescido de corante. }\end{array}$ & MAPA, 1981b \\
\hline $\begin{array}{lrr}\text { Portaria } & \mathrm{n}^{\circ} & 6 \\
\text { de } & 8 & \text { de }\end{array}$ & MAPA & $\begin{array}{l}\text { Fitossanitários } \\
\text { agrotóxicos }\end{array}$ & $\begin{array}{l}\text { Aprova normas sobre registro e renovação de produtos fitossanitários ou } \\
\text { defensivos agrícolas. }\end{array}$ & GARCIA, 2001. \\
\hline
\end{tabular}




\begin{tabular}{|c|c|c|c|c|}
\hline $\begin{array}{c}\text { Instrumento } \\
\text { Legal }\end{array}$ & $\begin{array}{c}\text { Órgão(s) } \\
\text { Envolvido(s) na } \\
\text { Aplicação }\end{array}$ & $\begin{array}{c}\text { Substâncias } \\
\text { Químicas envolvidas }\end{array}$ & Objetivo da Legislação & Referência \\
\hline \multicolumn{5}{|l|}{$\begin{array}{ll}\text { fevereiro de } \\
1985 .\end{array}$} \\
\hline $\begin{array}{l}\text { Portaria } \mathrm{n}^{\circ} 10 \\
\text { de } 08 \text { de março } \\
\text { de } 1985\end{array}$ & MS & Geral & $\begin{array}{l}\text { Relação de } \\
\text { sobre animais/plantas, cujo registro pode ser autorizado, em } \\
\text { atividades agropecuárias e produtos domissanitários e determina outras } \\
\text { providências. Revogada pela Resolução RE } n^{\circ} 165,29 / 8 / 2003 \text {. }\end{array}$ & \\
\hline 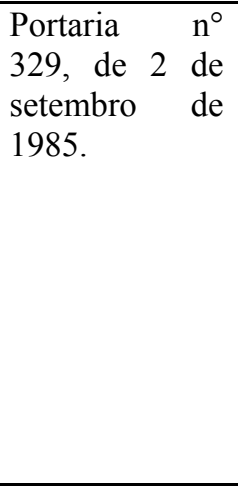 & MAPA & 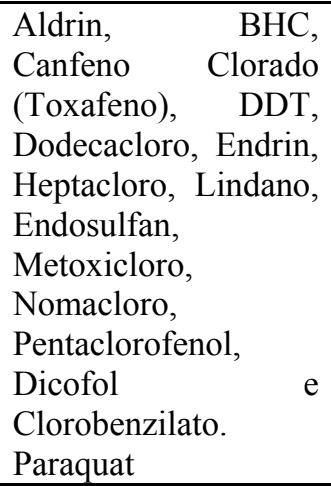 & $\begin{array}{l}\text { Proíbe a comercialização, uso e distribuição de produtos agrotóxicos } \\
\text { organoclorados destinados à agropecuária, com exceção para iscas } \\
\text { formicidas à base de Aldrin e Dodecacloro, uso de cupinicidas à base de } \\
\text { Aldrin para o emprego em florestamento e reflorestamento, uso em } \\
\text { campanhas de saúde pública de combate a vetores de agentes etiológicos de } \\
\text { moléstias, uso emergencial na agricultura. PARAQUAT somente sob a } \\
\text { forma de venda aplicada. }\end{array}$ & MAPA, 1985. \\
\hline $\begin{array}{l}\text { Portaria } \mathrm{n}^{\circ} \\
3.067 \text {, de } 12 \mathrm{de} \\
\text { abril de } 1988\end{array}$ & MTE & $\begin{array}{l}\text { Fertilizantes, } \\
\text { agrotóxicos e afins }\end{array}$ & $\begin{array}{l}\text { Aprova as Normas Regulamentadoras Rurais (NRR), relativas à segurança } \\
\text { e higiene do trabalho rural. Inclui a NRR } 5 \text { que trata de produtos químicos } \\
\text { (especialmente agrotóxicos e afins, fertilizantes e corretivos). Estabelece, } \\
\text { entre outros, a exigência de rotulagem dos produtos químicos segundo a } \\
\text { legislação vigente, conservação nas embalagens originais, transporte em } \\
\text { recipientes rotulados, herméticos e resistentes, cuidados com embalagens } \\
\text { marcadas como frágeis e recomendações especiais quanto a vazamentos. }\end{array}$ & LUNA et al. 2004 \\
\hline $\begin{array}{l}\text { Portaria } \\
\text { Interministerial } \\
n^{\circ} 292 \text {, de } 28 \\
\text { de abril de } \\
1989 .\end{array}$ & $\begin{array}{l}\text { MF, MS, MMA, } \\
\text { IBAMA }\end{array}$ & $\begin{array}{l}\text { Preservativos } \mathrm{de} \\
\text { madeira }\end{array}$ & $\begin{array}{l}\text { Determina que as empresas que se dedicam à indústria e comércio de } \\
\text { preservativos e preservação de madeiras devem ser registradas junto ao } \\
\text { IBAMA. Dentre os dados solicitados para o registro, está a Licença de } \\
\text { Operação expedida pelo órgão ambiental competente. } \\
\text { Regulamentada pela Instrução Normativa } n^{\circ} 5 \text {, de } 20 \text { de outubro de } 1992\end{array}$ & IBAMA, 1989. \\
\hline
\end{tabular}




\begin{tabular}{|c|c|c|c|c|}
\hline $\begin{array}{l}\text { Instrumento } \\
\text { Legal }\end{array}$ & $\begin{array}{l}\text { Órgão(s) } \\
\text { Envolvido(s) na } \\
\text { Aplicação }\end{array}$ & $\begin{array}{c}\text { Substâncias } \\
\text { Químicas envolvidas }\end{array}$ & Objetivo da Legislação & Referência \\
\hline $\begin{array}{l}\text { Lei } \mathrm{n}^{\mathrm{o}} 7.802 \\
\text { de } 11 \text { de julho } \\
\text { de } 1989 .\end{array}$ & $\begin{array}{l}\text { MAPA, MS, } \\
\text { MMA }\end{array}$ & $\begin{array}{l}\text { Agrotóxicos, seus } \\
\text { componentes e afins }\end{array}$ & $\begin{array}{l}\text { Dispõe sobre a pesquisa, a experimentação, a produção, a embalagem e } \\
\text { rotulagem, o transporte, o armazenamento, a comercialização, a } \\
\text { propaganda comercial, a utilização, a importação, a exportação, o destino } \\
\text { final dos resíduos e embalagens, o registro, a classificação, o controle, a } \\
\text { inspeção e a fiscalização de agrotóxicos, seus componentes e afins, e dá } \\
\text { outras providências. }\end{array}$ & BRASIL, 1989. \\
\hline $\begin{array}{l}\text { Decreto } 98.816 \\
\text { de } 11 \\
\text { janeiro } \\
1990\end{array}$ & $\begin{array}{l}\text { MAPA, MS, } \\
\text { MMA }\end{array}$ & $\begin{array}{l}\text { Agrotóxicos, seus } \\
\text { componentes e afins }\end{array}$ & Regulamenta a Lei 7.802 de 11 de julho de 1989. & BRASIL, 1990a. \\
\hline $\begin{array}{l}\text { Portaria } 349 \text { de } \\
14 \text { de março de } \\
1990\end{array}$ & IBAMA & Agrotóxicos & $\begin{array}{l}\text { Estabelece os procedimentos a serem seguidos junto ao IBAMA para efeito } \\
\text { de registro, renovação de registro e extensão de uso para agrotóxicos. }\end{array}$ & IBAMA, 1990. \\
\hline $\begin{array}{l}\text { Resolução } \mathrm{n}^{\circ} \\
344 \text {, de } 27 \text { de } \\
\text { julho de } 1990\end{array}$ & CONFEA & $\begin{array}{l}\text { Agrotóxicos, seus } \\
\text { componentes e afins }\end{array}$ & $\begin{array}{l}\text { Conselho Federal de Engenharia, Arquitetura e Agronomia - define as } \\
\text { categorias profissionais habilitadas a assumir Responsabilidade Técnica na } \\
\text { prescrição de produtos agrotóxicos, sua aplicação e atividades afins. }\end{array}$ & \\
\hline $\begin{array}{l}\text { Decreto no } \\
99.657 \text {, de } 26 \\
\text { de outubro de } \\
1990\end{array}$ & $\begin{array}{l}\text { MAPA, MS, } \\
\text { MMA }\end{array}$ & $\begin{array}{l}\text { Agrotóxicos, seus } \\
\text { componentes e afins }\end{array}$ & $\begin{array}{l}\text { Revogado pelo Decreto } n^{\circ} 4.074 \text { de } 4 \text { de janeiro de } 2002 \text {. Altera o Decreto } \\
n^{\circ} 98.816 \text {, de } 11 \text { de janeiro de } 1990 \text {. Prorroga o prazo de validade dos } \\
\text { registros dos agrotóxicos e afins, com data de expiração fixada até } 11 \text { de } \\
\text { janeiro de } 1991 \text {. }\end{array}$ & BRASIL, $1990 \mathrm{~b}$. \\
\hline $\begin{array}{ll}\begin{array}{l}\text { Portaria } \mathrm{n}^{\circ} \\
\text { de } \quad 30\end{array} & \text { de } \\
\text { novembro } & \text { de } \\
1990 & \end{array}$ & $\begin{array}{l}\text { MAPA - Séc. de } \\
\text { Defesa } \\
\text { Agropecuária }\end{array}$ & $\begin{array}{l}\text { Óleos minerais e } \\
\text { vegetais }\end{array}$ & $\begin{array}{l}\text { Reconhece os óleos minerais e vegetais, registrados no Ministério da } \\
\text { Agricultura e Reforma Agrária, como adjuvante, quando adicionados às } \\
\text { caldas dos agrotóxicos, e autoriza a sua recomendação e utilização de na } \\
\text { agricultura brasileira. }\end{array}$ & \\
\hline 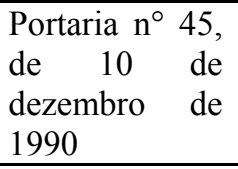 & $\begin{array}{l}\text { MAPA - Séc. de } \\
\text { Defesa } \\
\text { Agropecuária }\end{array}$ & Agrotóxicos & $\begin{array}{l}\text { Estabelece procedimentos para registro de agrotóxicos, seus componentes e } \\
\text { afins. }\end{array}$ & MAPA, 1990. \\
\hline $\begin{array}{l}\text { Portaria } \\
\text { Conjunta } \mathrm{n}^{\mathrm{o}} \\
86, \text { de } 25 \text { de } \\
\text { julho de } 1991 .\end{array}$ & $\begin{array}{l}\text { MAPA; MS; } \\
\text { Secretaria do } \\
\text { Meio Ambiente. }\end{array}$ & Agrotóxicos - CTA & Constitui a Comissão Técnica de Assessoramento para Agrotóxicos. & BRASIL, 1991. \\
\hline
\end{tabular}




\begin{tabular}{|c|c|c|c|c|}
\hline $\begin{array}{c}\text { Instrumento } \\
\text { Legal }\end{array}$ & $\begin{array}{c}\text { Órgão(s) } \\
\text { Envolvido(s) na } \\
\text { Aplicação } \\
\end{array}$ & $\begin{array}{c}\text { Substâncias } \\
\text { Químicas envolvidas }\end{array}$ & Objetivo da Legislação & Referência \\
\hline 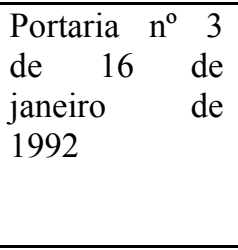 & $\begin{array}{l}\text { MS - Secretaria de } \\
\text { Vigilância } \\
\text { Sanitária }\end{array}$ & Agrotóxicos e afins & $\begin{array}{l}\text { Ratifica os termos das "Diretrizes e orientações referentes à autorização de } \\
\text { registros, renovação de registro e extensão de uso de produtos agrotóxicos e } \\
\text { afins - n }{ }^{0} 1 \text {, de } 9 \text { de dezembro de 1991, publicadas no D.O.U. em 13/12/91 } \\
\text { (apresentada como anexo à Portaria). } \\
\text { Define aspectos a serem considerados na avaliação de riscos toxicológicos. } \\
\text { Apresenta, no Anexo III, critérios para a classificação toxicológica. }\end{array}$ & ANVISA, 1992. \\
\hline $\begin{array}{ll}\text { Portaria } \mathrm{n}^{\circ} & 14 \\
\text { de } 24 & \text { de } \\
\text { janeiro } & \text { de } \\
1992 . & \end{array}$ & $\begin{array}{l}\text { MS - Secretaria de } \\
\text { Vigilância } \\
\text { Sanitária }\end{array}$ & Agrotóxicos e afins & $\begin{array}{l}\text { Estabelece normas para a avaliação toxicológica preliminar dos produtos } \\
\text { agrotóxicos e afins destinados à pesquisa e experimentação, ressaltando a } \\
\text { importância do incentivo à pesquisa e experimentação, bem como a sua } \\
\text { realização dentro de parâmetros que minimizem os riscos à saúde dos } \\
\text { pesquisadores e da população em geral. }\end{array}$ & MS, 1992. \\
\hline $\begin{array}{l}\text { Portaria } n^{\circ} 63 \text {, } \\
\text { de } 15 \text { de junho } \\
\text { de } 1992\end{array}$ & $\begin{array}{l}\text { MAPA - Séc. de } \\
\text { Defesa } \\
\text { Agropecuária }\end{array}$ & Aldrin & $\begin{array}{l}\text { Proíbe, em todo o território nacional, a produção, exportação, importação, } \\
\text { comercialização e a utilização do ingrediente ativo Aldrin, organoclorado, } \\
\text { destinado à agropecuária. }\end{array}$ & $\begin{array}{l}\text { D'AMATO et al. } \\
2002 \text {. }\end{array}$ \\
\hline $\begin{array}{lr}\text { Portaria } \mathrm{n}^{\circ} & 82 \\
\text { de } \quad 08 & \text { de } \\
\text { outubro } & \text { de } \\
1992 & \end{array}$ & $\begin{array}{l}\text { MAPA - Séc. de } \\
\text { Defesa } \\
\text { Agropecuária }\end{array}$ & Clorobenzilato & $\begin{array}{l}\text { Proíbe, em todo o território nacional, a produção, exportação, importação, } \\
\text { comercialização e a utilização do ingrediente ativo clorobenzilato, } \\
\text { organoclorado, destinado à agropecuária; e dá outras providências. }\end{array}$ & MAPA, 1992a. \\
\hline $\begin{array}{ll}\text { Instrução } & \\
\text { Normativa } & \mathrm{n}^{\circ} \\
5, \quad \text { de } & 20 \\
\text { outubro } & \text { de } \\
1992 & \end{array}$ & IBAMA & $\begin{array}{l}\text { Preservativos } \\
\text { madeira }\end{array}$ & $\begin{array}{l}\text { Dispõe sobre o registro de produtos para a preservação da madeira de } \\
\text { unidades industriais e preservadoras de madeira, cadastro de usuários, } \\
\text { rotulagem e embalagem, comercialização, destinação final de resíduos, } \\
\text { embalagens e importação. } \\
\text { Determina que comercialização de produtos preservativos de madeira que } \\
\text { contenham ingrediente(s) ativo(s) organoclorado(s) (pentaclorofenol e seus } \\
\text { sais, heptacloro, aldrin, lindane, clordane e outros), só será permitida na } \\
\text { forma de venda direta entre os produtores e/ou importadores. }\end{array}$ & \\
\hline $\begin{array}{ll}\text { Portaria } \mathrm{n}^{\circ} & 91 \\
\text { de } \quad 30 & \text { de } \\
\text { novembro } & \text { de } \\
1992 & \end{array}$ & $\begin{array}{l}\text { MAPA - Séc. de } \\
\text { Defesa } \\
\text { Agropecuária }\end{array}$ & $\begin{array}{l}\text { Hexaclorociclopentad } \\
\text { ieno, e Dodecacloro }\end{array}$ & $\begin{array}{l}\text { Proíbe a importação da matéria-prima hexaclorociclopentadieno para ser } \\
\text { utilizado na fabricação do ingrediente ativo do dodecacloro; proíbe em todo } \\
\text { o território nacional, a partir de } 1^{\circ} \text { de maio de } 1993 \text {, o registro, a produção, } \\
\text { a importação, a exportação, a comercialização e a utilização de iscas } \\
\text { formicidas à base de dodecacloro; e dá outras providências. }\end{array}$ & MAPA, 1992b. \\
\hline $\begin{array}{lr}\text { Decreto } & 991, \\
\text { de } \quad 24 & \text { de } \\
\end{array}$ & $\begin{array}{l}\text { MAPA, } \\
\text { MMA }\end{array}$ & $\begin{array}{l}\text { Agrotóxicos, seus } \\
\text { componentes e afins }\end{array}$ & $\begin{array}{l}\text { Revogado pelo Decreto } \mathrm{n}^{\circ} 4.074 \text { de } 4 \text { de janeiro de } 2002 \text {. Altera o Decreto } \\
\mathrm{n}^{\circ} 98.816 \text {, de } 11 \text { de janeiro de } 1990 \text {. Modificação em exigências relativas }\end{array}$ & BRASIL, 1993. \\
\hline
\end{tabular}




\begin{tabular}{|c|c|c|c|c|}
\hline $\begin{array}{l}\text { Instrumento } \\
\text { Legal }\end{array}$ & $\begin{array}{l}\text { Órgão(s) } \\
\text { Envolvido(s) na } \\
\text { Aplicação }\end{array}$ & $\begin{array}{c}\text { Substâncias } \\
\text { Químicas envolvidas }\end{array}$ & Objetivo da Legislação & Referência \\
\hline $\begin{array}{l}\text { novembro de } \\
1993\end{array}$ & & & $\begin{array}{l}\text { aos dados e informações a serem apresentados pelo requerente, para efeito } \\
\text { de registro de agrotóxicos, seus componentes e afins }\end{array}$ & \\
\hline $\begin{array}{l}\text { Portaria } \mathrm{n}^{\circ} 84 \\
\text { de } 9 \text { de maio } \\
\text { de } 1994\end{array}$ & $\begin{array}{l}\text { MAPA - Séc. de } \\
\text { Defesa } \\
\text { Agropecuária }\end{array}$ & $\begin{array}{l}\text { Agrotóxicos, seus } \\
\text { componentes e afins }\end{array}$ & $\begin{array}{l}\text { Estabelece critérios para avaliar inclusões e exclusões de indicações de } \\
\text { usos nos registros dos agrotóxicos }\end{array}$ & MAPA, 1994. \\
\hline $\begin{array}{l}\text { Portaria } n^{\circ} 93, \\
\text { de } 30 \text { de maio } \\
\text { de } 1994\end{array}$ & $\begin{array}{l}\text { MAPA - Séc. de } \\
\text { Defesa } \\
\text { Agropecuária }\end{array}$ & $\begin{array}{l}\text { Agrotóxicos, seus } \\
\text { componentes e afins }\end{array}$ & Instruções sobre o rótulo e bula de agrotóxicos. & \\
\hline $\begin{array}{ll}\text { Portaria } & \\
\text { Normativa } & \mathrm{n}^{\mathrm{o}} \\
139, \text { de } 21 & \mathrm{de} \\
\text { dezembro } & \mathrm{de} \\
1994 & \\
\end{array}$ & IBAMA & $\begin{array}{l}\text { Agrotóxicos, seus } \\
\text { componentes e afins }\end{array}$ & $\begin{array}{l}\text { Estabelece procedimentos a serem adotados junto ao IBAMA, para efeito } \\
\text { de avaliação do potencial de periculosidade ambiental de produtos } \\
\text { químicos considerados como agrotóxicos, seus componentes e afins. }\end{array}$ & IBAMA, 1994. \\
\hline $\begin{array}{l}\text { Portaria } \mathrm{n}^{\circ} 67 \\
\text { de } 30 \text { de maio } \\
\text { de } 1995\end{array}$ & $\begin{array}{l}\text { MAPA - Séc. de } \\
\text { Defesa } \\
\text { Agropecuária }\end{array}$ & $\begin{array}{l}\text { Agrotóxicos, seus } \\
\text { componentes e afins }\end{array}$ & $\begin{array}{l}\text { Regulamenta a prática de mistura de tanque, ou seja, associação, } \\
\text { imediatamente antes da aplicação, de agrotóxicos ou afins necessários ao } \\
\text { controle de alvos biológicos que ocorrem simultaneamente. }\end{array}$ & MAPA, 1995. \\
\hline $\begin{array}{l}\text { Lei } n^{\circ} 9.294 \\
\text { de } 15 \text { de julho } \\
\text { de } 1996\end{array}$ & MS & $\begin{array}{l}\text { Agrotóxicos e outras } \\
\text { substâncias químicas } \\
\text { - propaganda }\end{array}$ & $\begin{array}{l}\text { Determina as restrições ao uso e à propaganda de agrotóxicos e outras } \\
\text { substâncias químicas. }\end{array}$ & BRASIL, 1996. \\
\hline $\begin{array}{l}\text { Portaria } \mathrm{n}^{\circ} 95 \\
\text { de } 31 \text { de julho } \\
\text { de } 1996\end{array}$ & $\begin{array}{l}\text { MAPA - Séc. de } \\
\text { Defesa } \\
\text { Agropecuária }\end{array}$ & $\begin{array}{l}\text { Agrotóxicos, seus } \\
\text { componentes e afins }\end{array}$ & $\begin{array}{l}\text { Institui o cadastro de estabelecimentos registrados, formuladores, } \\
\text { fabricantes, exportadores e importadores de agrotóxicos, seus componentes } \\
\text { e afins }\end{array}$ & \\
\hline $\begin{array}{lr}\text { Decreto } & \mathrm{n}^{\circ} \\
2.018, \text { de } & 1^{\circ} \mathrm{de} \\
\text { outubro } & \text { de } \\
1996 & \end{array}$ & $\begin{array}{l}\text { MAPA, } \quad \text { MS, } \\
\text { MMA }\end{array}$ & $\begin{array}{l}\text { Agrotóxicos, seus } \\
\text { componentes e afins } \\
\text { - propaganda }\end{array}$ & $\begin{array}{l}\text { Regulamenta a Lei no } 9294 \text {, de } 15 \text { de julho de 1996, que dispõe sobre as } \\
\text { restrições ao uso e à propaganda de agrotóxicos. }\end{array}$ & \\
\hline $\begin{array}{ll}\text { Portaria } & \\
\text { Normativa } & \mathrm{n}^{\mathrm{o}} \\
84 \text { de } 15 & \mathrm{de} \\
\text { outubro } & \mathrm{de} \\
1996 & \\
\end{array}$ & IBAMA & Agrotóxicos e afins & $\begin{array}{l}\text { Estabelece procedimentos a serem adotados junto ao IBAMA para efeito de } \\
\text { registro e avaliação do potencial de periculosidade ambiental (ppa) de } \\
\text { agrotóxicos. }\end{array}$ & IBAMA, 1996. \\
\hline $\begin{array}{ll}\text { Portaria } & \mathrm{n}^{\circ} \\
138, \text { de } 21 & \text { de }\end{array}$ & $\begin{array}{l}\text { MAPA - Séc. de } \\
\text { Defesa }\end{array}$ & $\begin{array}{l}\text { Agrotóxicos, seus } \\
\text { componentes e afins }\end{array}$ & $\begin{array}{l}\text { Define o credenciamento de entidades privadas de ensino e de pesquisa } \\
\text { para desenvolver pesquisas e ensaios experimentais com agrotóxicos. }\end{array}$ & \\
\hline
\end{tabular}




\begin{tabular}{|c|c|c|c|c|}
\hline $\begin{array}{l}\text { Instrumento } \\
\text { Legal }\end{array}$ & $\begin{array}{l}\text { Órgão(s) } \\
\text { Envolvido(s) na } \\
\text { Aplicação }\end{array}$ & $\begin{array}{c}\text { Substâncias } \\
\text { Químicas envolvidas }\end{array}$ & Objetivo da Legislação & Referência \\
\hline $\begin{array}{l}\text { novembro de } \\
1996\end{array}$ & Agropecuária & & & \\
\hline $\begin{array}{ll}\text { Portaria } & n^{\circ} \\
149, \text { de } 26 & \text { de } \\
\text { dezembro } & \text { de } \\
1996 & \end{array}$ & ANVISA & $\begin{array}{l}\text { Agrotóxicos para } \\
\text { florestas }\end{array}$ & $\begin{array}{l}\text { Estabelece procedimentos para registro de agrotóxicos, seus componentes e } \\
\text { afins, destinados ao uso na proteção de florestas. }\end{array}$ & \\
\hline $\begin{array}{lr}\text { Portaria } \mathrm{n}^{\circ} & 160 \\
\text { de } \quad 31 & \text { de } \\
\text { dezembro } & \text { de } \\
1996 & \end{array}$ & $\begin{array}{l}\text { MAPA - Séc. de } \\
\text { Defesa } \\
\text { Agropecuária }\end{array}$ & $\begin{array}{l}\text { Agrotóxicos, seus } \\
\text { componentes e afins }\end{array}$ & $\begin{array}{l}\text { Complementação das Portarias } \mathrm{n}^{\circ} 45 \text {, de } 10 \text { de dezembro de } 1990 \text { e } \mathrm{n}^{\circ} \\
\text { 84/1994, relativas a obtenção de registro e reavaliação técnica de } \\
\text { agrotóxicos, seus componentes e afins. }\end{array}$ & MAPA, 1996. \\
\hline $\begin{array}{l}\text { Portaria } 168, \\
\text { de } 15 \text { de maio } \\
\text { de } 1997 .\end{array}$ & $\begin{array}{l}\text { MS - Secretaria de } \\
\text { Vigilância } \\
\text { Sanitária }\end{array}$ & $\begin{array}{l}\text { Agrotóxicos, seus } \\
\text { componentes e afins }\end{array}$ & $\begin{array}{l}\text { Institui em nível nacional a Vigilância Epidemiológica no uso dos } \\
\text { agrotóxicos, no âmbito do Sistema Único de Saúde - Programa de } \\
\text { Vigilância Sanitária dos Ambientes e das populações expostas a } \\
\text { Agrotóxicos. }\end{array}$ & Luna et al. 2004. \\
\hline 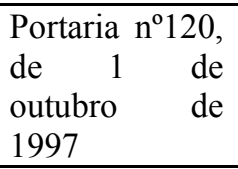 & $\begin{array}{l}\text { MAPA - Séc. de } \\
\text { Defesa } \\
\text { Agropecuária }\end{array}$ & $\begin{array}{l}\text { Agrotóxicos, seus } \\
\text { componentes e afins }\end{array}$ & $\begin{array}{l}\text { Regulamentação de registro de agrotóxicos destinados às culturas } \\
\text { hortícolas, frutíferas e ornamentais. }\end{array}$ & \\
\hline 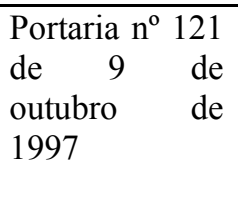 & $\begin{array}{l}\text { MAPA - Séc. de } \\
\text { Defesa } \\
\text { Agropecuária }\end{array}$ & $\begin{array}{l}\text { feromônio, alomônio } \\
\text { e cairomônio }\end{array}$ & $\begin{array}{l}\text { Regulamentação do uso de produtos denominados semioquímicos } \\
\text { (substâncias químicas emitidas por plantas e animais que modificam o } \\
\text { comportamento de organismos receptores) - feromônio, alomônio e } \\
\text { cairomônio, utilizados nas práticas de manejo integrado de pragas na } \\
\text { agricultura. }\end{array}$ & \\
\hline $\begin{array}{ll}\text { Portaria } & \\
\text { normativa } & \mathrm{n}^{\circ} \\
131, \text { de } 3 & \text { de } \\
\text { novembro } & \text { de } \\
1997 & \end{array}$ & IBAMA & Agentes biológicos & $\begin{array}{l}\text { Estabelece procedimentos para efeito de registro e avaliação ambiental de } \\
\text { agentes biológicos empregados no controle de uma população ou de } \\
\text { atividades biológicas de um outro organismo vivo considerado nocivo, } \\
\text { visando a defesa fitossanitária. } \\
\text { Ressalta que os testes e informações constantes foram estabelecidos de } \\
\text { modo a prover dados básicos para a realização da avaliação do risco } \\
\text { ambiental de agentes biológicos de controle }\end{array}$ & \\
\hline
\end{tabular}




\begin{tabular}{|c|c|c|c|c|}
\hline $\begin{array}{c}\text { Instrumento } \\
\text { Legal }\end{array}$ & $\begin{array}{l}\text { Órgão(s) } \\
\text { Envolvido(s) na } \\
\text { Aplicação }\end{array}$ & $\begin{array}{c}\text { Substâncias } \\
\text { Químicas envolvidas }\end{array}$ & Objetivo da Legislação & Referência \\
\hline $\begin{array}{l}\text { Portaria } n^{\circ} 11 \\
\text { de } 8 \text { de janeiro } \\
\text { de } 1998\end{array}$ & $\mathrm{MS}$ & $\begin{array}{l}\text { Aldrin, B.H.C., } \\
\text { Clorobenzilato, DDT, } \\
\text { Endrin, Heptacloro, } \\
\text { Lindano, Paration e } \\
\text { P.C.P. }\end{array}$ & $\begin{array}{l}\text { Exclui da "Relação de Substâncias com Ação Tóxica sobre Animais ou } \\
\text { Plantas cujo Registro pode ser Autorizado no Brasil, em Atividades } \\
\text { Agropecuárias e Produtos Domissanitários", constante da Portaria n } 10 \text {, de } \\
8 \text { de fevereiro de1985, DOU de } 14 \text { de fevereiro de85, Anexos I e II, as } \\
\text { seguintes monografias: A-09 Aldrin, B-04 B.H.C., C-16 Clorobenzilato, D- } \\
07 \text { DDT, E-03 Endrin, H-01 Heptacloro, L-01 Lindano, P-02 Paration E P- } \\
\text { 24 P.C.P. Pentaclorofenol. }\end{array}$ & MS, 1998. \\
\hline $\begin{array}{ll}\text { Resolução } & \mathrm{n}^{\circ} \\
5, \text { de } 14 & \text { de } \\
\text { outubro } & \text { de } \\
1999 & \end{array}$ & ANVISA & Agrotóxicos e afins & $\begin{array}{l}\text { Suspende a aprovação e a avaliação toxicológica para registro de novas } \\
\text { formulações de produtos agrotóxicos com a mistura de ingredientes ativos } \\
\text { considerados potencialmente carcinogênicos. }\end{array}$ & ANVISA, 1999a. \\
\hline $\begin{array}{ll}\text { Resolução } & n^{\circ} \\
6, \text { de } 14 & \text { de } \\
\text { outubro } & \text { de } \\
1999 & \end{array}$ & ANVISA & $\begin{array}{l}\text { Paration Metílico e } \\
\text { Metamidofós }\end{array}$ & $\begin{array}{l}\text { Suspender a aprovação e a avaliação toxicológica para registro de novos } \\
\text { produtos técnicos e/ou formulações de agrotóxicos à base de Paration } \\
\text { Metílico e Metamidofós e Reavaliar toxicologicamente os produtos } \\
\text { técnicos. }\end{array}$ & ANVISA, $1999 b$. \\
\hline $\begin{array}{ll}\text { Resolução } & \mathrm{n}^{\circ} \\
7, \text { de } 14 & \text { de } \\
\text { outubro } & \text { de } \\
1999 & \end{array}$ & $\overline{A N V I S A}$ & Alachlor & $\begin{array}{l}\text { Suspender a aprovação e a avaliação toxicológica para registro de novas } \\
\text { formulações e misturas de produtos técnicos com o princípio ativo } \\
\text { Alachlor. e Reavaliar toxicologicamente todas as formulações e misturas. }\end{array}$ & ANVISA, 1999c. \\
\hline $\begin{array}{l}\text { Portaria } \mathrm{N}^{\circ} \\
1.399, \text { de } 15 \text { de } \\
\text { dezembro de } \\
1999\end{array}$ & MS & $\begin{array}{l}\text { Agrotóxicos, } \\
\text { mercúrio, benzeno e } \\
\text { outras }\end{array}$ & $\begin{array}{l}\text { Determina que várias ações competem aos Estado, na gestão do } \\
\text { componente estadual do Sistema Nacional de Vigilância Epidemiológica } \\
\text { Ambiental em Saúde, dentre elas: coordenação das ações de vigilância } \\
\text { ambiental de fatores BRASIL - de risco à saúde humana, incluindo o } \\
\text { monitoramento da água de consumo humano e contaminantes com } \\
\text { importância em saúde pública, como os agrotóxicos, mercúrio e benzeno; }\end{array}$ & \\
\hline $\begin{array}{l}\text { Resolução - } \\
\text { RDC n } 44, \text { de } \\
10 \text { de maio de } \\
2000\end{array}$ & ANVISA & Agrotóxicos e afins & $\begin{array}{l}\text { Altera as "Diretrizes e orientações referentes à autorização de registros, } \\
\text { renovação de registro e extensão de uso de produtos agrotóxicos e afins - } \text { n }^{\circ} \\
1 \text {, de } 9 \text { de dezembro de 1991, ratificada pela Portaria n } 3 \text { de } 16 \text { de Janeiro } \\
\text { de } 1992 .\end{array}$ & ANVISA, 2000a. \\
\hline $\begin{array}{l}\text { Lei } n^{\circ} 9.974 \\
\text { de } 6 \text { de junho } \\
\text { de } 2000\end{array}$ & $\begin{array}{l}\text { MAPA, } \\
\text { MMA }\end{array}$ & $\begin{array}{l}\text { Agrotóxicos, seus } \\
\text { componentes e afins }\end{array}$ & $\begin{array}{l}\text { Altera a Lei } \mathrm{n}^{\circ} 7.802 \text {, de } 11 \text { de julho de } 1989 \text {, no que se refere à } \\
\text { embalagens de agrotóxicos, fracionamento e a reembalagem de agrotóxicos } \\
\text { e afins, devolução de embalagens vazias dos produtos aos estabelecimentos } \\
\text { comerciais em que foram adquiridos, operação de tríplice lavagem, e }\end{array}$ & BRASIL, $2000 \mathrm{~b}$. \\
\hline
\end{tabular}




\begin{tabular}{|c|c|c|c|c|}
\hline $\begin{array}{c}\text { Instrumento } \\
\text { Legal }\end{array}$ & $\begin{array}{l}\text { Órgão(s) } \\
\text { Envolvido(s) na } \\
\text { Aplicação }\end{array}$ & $\begin{array}{c}\text { Substâncias } \\
\text { Químicas envolvidas }\end{array}$ & Objetivo da Legislação & Referência \\
\hline & & & $\begin{array}{l}\text { destinação pelas empresas produtoras e comercializadoras de agrotóxicos, } \\
\text { adequação dos equipamentos para pulverização, etc. }\end{array}$ & \\
\hline $\begin{array}{l}\text { Decreto no } \\
3.550 \text {, de } 27 \text { de } \\
\text { julho de } 2000\end{array}$ & $\begin{array}{l}\text { MAPA, } \quad \text { MS, } \\
\text { MMA }\end{array}$ & $\begin{array}{l}\text { Agrotóxicos, seus } \\
\text { componentes e afins }\end{array}$ & $\begin{array}{l}\text { Revogado pelo Decreto } \text { n }^{\circ} 4.074 \text { de } 4 \text { de janeiro de } 2002 \text {. Dá nova redação } \\
\text { a dispositivos do Decreto no } 98.816 \text {, de } 11 \text { de janeiro de } 1990 . \text { Instruções } \\
\text { sobre embalagens, rótulos e bulas. }\end{array}$ & BRASIL, 2000c. \\
\hline $\begin{array}{l}\text { Resolução } \text { RE } \\
\mathrm{n}^{\circ} \quad 104 \text { de } 17 \\
\text { de agosto de } \\
2000\end{array}$ & ANVISA & $\begin{array}{l}\text { Agrotóxicos, seus } \\
\text { componentes e afins }\end{array}$ & $\begin{array}{l}\text { Aprova a avaliação toxicológica de produtos, que contenham princípios } \\
\text { ativos de uso corrente no país, com base nas informações científicas } \\
\text { reconhecidas. }\end{array}$ & ANVISA, 2000b. \\
\hline $\begin{array}{l}\text { Resolução } \mathrm{n}^{\circ} \\
62 \text {, de } 30 \text { de } \\
\text { agosto de } 2000\end{array}$ & ANVISA & Lambdacyhalothrin & $\begin{array}{l}\text { Alterar na monografia L-04 LAMBDACYHALOTHRIN, constante da } \\
\text { "Relação de Substâncias com Ação Tóxica sobre Animais ou Plantas, cujo } \\
\text { registro pode ser Autorizado no Brasil, em Atividades Agropecuárias e } \\
\text { Produtos Domissanitários", com relação ao item "emprego agropecuário". }\end{array}$ & \\
\hline $\begin{array}{l}\text { Resolução } \mathrm{n}^{\circ} \\
63, \text { de } 30 \text { de } \\
\text { agosto de } 2000\end{array}$ & ANVISA & Indoxacarb & $\begin{array}{l}\text { Incluir na "Relação de Substâncias com Ação Tóxica sobre Animais ou } \\
\text { plantas, cujo registro pode ser Autorizado no Brasil, em Atividades } \\
\text { Agropecuárias e Produtos Domissanitários", a substância I-21 } \\
\text { INDOXACARB. }\end{array}$ & \\
\hline $\begin{array}{l}\text { Resolução } \mathrm{n}^{\circ} \\
64 \text {, de } 30 \text { de } \\
\text { agosto de } 2000\end{array}$ & ANVISA & Triadimenol & $\begin{array}{l}\text { Alterar na monografia T-31 TRIADIMENOL, constante da "Relação de } \\
\text { Substâncias com Ação Tóxica sobre Animais ou Plantas, cujo registro pode } \\
\text { ser Autorizado no Brasil, em Atividades Agropecuárias e Produtos } \\
\text { Domissanitários", com relação ao item "emprego agropecuário". }\end{array}$ & \\
\hline $\begin{array}{l}\text { Resolução } \mathrm{n}^{\circ} \\
65, \quad \text { de } 30 \\
\text { agosto de } 2000\end{array}$ & ANVISA & Tepraloxidim & $\begin{array}{l}\text { Incluir na "Relação de Substâncias com Ação Tóxica sobre Animais ou } \\
\text { plantas, cujo registro pode ser Autorizado no Brasil, em Atividades } \\
\text { Agropecuárias e Produtos Domissanitários", a substância r T-50 } \\
\text { TEPRALOXIDIM }\end{array}$ & \\
\hline $\begin{array}{l}\text { Resolução RE } \\
n^{\circ} 38 \text {, de } 09 \text { de } \\
\text { novembro de } \\
2000\end{array}$ & ANVISA & Prochloraz & $\begin{array}{l}\text { Altera, na monografia do PROCHLORAZ. Autorizado emprego } \\
\text { agropecuário para aplicação nas partes aéreas das culturas de arroz e } \\
\text { mamão. }\end{array}$ & \\
\hline $\begin{array}{ll}\text { Resolução } & - \\
\text { RDC n } & \\
20 & \text { de } \\
\text { novembro } & \text { de }\end{array}$ & ANVISA & Lindano & $\begin{array}{l}\text { Atualização das listas de substâncias sujeitas a controle especial. Inclui o } \\
\text { LINDANO na lista das substâncias de uso proscrito no Brasil, mas ressalta } \\
\text { que fica autorizado o seu uso de como preservativo de madeira, sob o } \\
\text { controle do IBAMA. }\end{array}$ & ANVISA, 2000c. \\
\hline
\end{tabular}




\begin{tabular}{|c|c|c|c|c|}
\hline $\begin{array}{l}\text { Instrumento } \\
\text { Legal }\end{array}$ & $\begin{array}{l}\text { Órgão(s) } \\
\text { Envolvido(s) na } \\
\text { Aplicação } \\
\end{array}$ & $\begin{array}{c}\text { Substâncias } \\
\text { Químicas envolvidas }\end{array}$ & Objetivo da Legislação & Referência \\
\hline \multicolumn{5}{|l|}{2000} \\
\hline $\begin{array}{l}\text { Decreto } \mathrm{n}^{\circ} \\
3.694 \text {, de } 21 \mathrm{de} \\
\text { dezembro de } \\
2000 .\end{array}$ & $\begin{array}{l}\text { MAPA, } \quad \text { MS, } \\
\text { MMA }\end{array}$ & $\begin{array}{l}\text { Agrotóxicos, seus } \\
\text { componentes e afins }\end{array}$ & $\begin{array}{l}\text { Revogado pelo Decreto } \mathrm{n}^{\circ} 4.074 \text { de } 4 \text { de janeiro de } 2002 \text {. Dá nova redação } \\
\text { a dispositivos do Decreto no } 98.816 \text {, de } 11 \text { de janeiro de } 1990 \text {. Instruções } \\
\text { sobre embalagens, rótulos e bulas }\end{array}$ & \\
\hline $\begin{array}{l}\text { Lei } \mathrm{n}^{\circ} \quad 10.167, \\
\text { de } 27 \quad \text { de } \\
\text { dezembro } \\
2000\end{array}$ & - & $\begin{array}{l}\text { Agrotóxicos, seus } \\
\text { componentes e afins }\end{array}$ & Define as restrições à propaganda. & BRASIL, 2000d. \\
\hline $\begin{array}{l}\text { Portaria } \mathrm{n}^{\circ} \\
1.469, \text { de } 29 \\
\text { de Dezembro } \\
\text { de } 2000 .\end{array}$ & MS & Agrotóxicos & $\begin{array}{l}\text { Estabelece os procedimentos e responsabilidades relativas ao controle e } \\
\text { vigilância da qualidade da água para consumo humano e seu padrão de } \\
\text { potabilidade, e dá outras providências. Padrão de potabilidade para } \\
\text { substâncias químicas que representam risco à saúde. Revogada pela } \\
\text { Portaria } \mathrm{n}^{\circ} 518 \text {, de } 25 \text { de março de } 2004\end{array}$ & MS, 2000. \\
\hline $\begin{array}{l}\text { Decreto } \mathrm{n}^{\circ} \\
3.828 \text {, de } 31 \mathrm{de} \\
\text { maio de } 2001\end{array}$ & $\begin{array}{l}\text { MAPA, } \quad \text { MS, } \\
\text { MMA }\end{array}$ & $\begin{array}{l}\text { Agrotóxicos, seus } \\
\text { componentes e afins. }\end{array}$ & $\begin{array}{l}\text { Altera e inclui dispositivos ao Decreto no } 98.816 \text {, de } 11 \text { de janeiro de } 1990 \text {, } \\
\text { sobre operações de recebimento, recolhimento e destinação de embalagens } \\
\text { vazias, importação e comercialização de matérias-primas, ingredientes } \\
\text { inertes e aditivos, rótulos e bulas. }\end{array}$ & \\
\hline $\begin{array}{l}\text { Resolução RE } \\
n^{\circ} 154 \text {, de } 19 \\
\text { de julho de } \\
2001\end{array}$ & ANVISA & Metamidofós & $\begin{array}{l}\text { Altera a monografia do METAMIDOFÓS. Reavaliação concluída em } \\
\text { dezembro de } 2000\end{array}$ & \\
\hline $\begin{array}{l}\text { Resolução RE } \\
n^{\circ} 155 \text {, de } 19 \\
\text { de julho de } \\
2001\end{array}$ & ANVISA & Alaclor & Altera a monografia do ALACLOR & \\
\hline $\begin{array}{ll}\text { Instrução } & \\
\text { normativa } & \mathrm{n}^{\mathrm{o}} \\
\text { de } \quad 25 & \text { de } \\
\text { setembro } & \text { de } \\
2001 & \end{array}$ & FUNASA & Produtos perigosos & $\begin{array}{l}\text { Define competências da União (FUNASA) na área de vigilância ambiental } \\
\text { em saúde. }\end{array}$ & \\
\hline
\end{tabular}




\begin{tabular}{|c|c|c|c|c|}
\hline $\begin{array}{l}\text { Instrumento } \\
\text { Legal }\end{array}$ & $\begin{array}{c}\text { Órgão(s) } \\
\text { Envolvido(s) na } \\
\text { Aplicação } \\
\end{array}$ & $\begin{array}{c}\text { Substâncias } \\
\text { Químicas envolvidas }\end{array}$ & Objetivo da Legislação & Referência \\
\hline $\begin{array}{ll}\text { Portaria } & \\
\text { Conjunta } & \text { n. } \\
\text { de } \quad 25 & \text { de } \\
\text { outubro } & \text { de } \\
2001 & \end{array}$ & $\begin{array}{l}\text { MAPA, } \quad \text { MS, } \\
\text { MMA }\end{array}$ & $\begin{array}{l}\text { Benomil } \\
\text { carbendazim }\end{array}$ & $\begin{array}{l}\text { Determina a reavaliação toxicológica e ambiental dos produtos técnicos e } \\
\text { formulados a base de benomil e carbendazim, por meio de uma Comissão } \\
\text { Técnica integrada por dois representantes de cada um dos órgãos } \\
\text { (ANVISA, IBAMA, MAPA, SINDAG). }\end{array}$ & ANVISA, 2001. \\
\hline $\begin{array}{lr}\text { Decreto } & \mathrm{n}^{\circ} \\
4.074, \text { de } & 4 \text { de } \\
\text { janeiro } & \text { de } \\
2002 & \\
\end{array}$ & $\begin{array}{l}\text { MAPA, } \quad \text { MS, } \\
\text { MMA }\end{array}$ & $\begin{array}{l}\text { Agrotóxicos, seus } \\
\text { componentes e afins }\end{array}$ & $\begin{array}{l}\text { Regulamenta a Lei } \mathrm{n}^{\circ} 7.802 \text { de } 11 \text { de julho de } 1989 \text { e revoga os Decretos } \mathrm{n}^{\circ} \\
98.816 \text { de } 11 \text { de janeiro de } 1990, \mathrm{n}^{\circ} 99.657 \text { de } 26 \text { de outubro de } 1990, \mathrm{n}^{\circ} \\
991 \text { de } 24 \text { de novembro de } 1993, \mathrm{n}^{\circ} 3,550 \text { de } 27 \text { de julho de } 2000,3.694 \text { de } \\
21 \text { de dezembro de } 2000 \text { e }^{\circ} 3.828 \text { de } 31 \text { de maio de } 2001 \text {. }\end{array}$ & BRASIL, 2002a. \\
\hline $\begin{array}{l}\text { Resolução RE } \\
\mathrm{n}^{\circ} 42, \text { de } 18 \text { de } \\
\text { abril de } 2002\end{array}$ & ANVISA & Clorpirifos & $\begin{array}{l}\text { Altera, na monografia do CLORPIRIFOS. Autoriza emprego Agropecuário } \\
\text { em partes aéreas das culturas de algodão, amendoim, banana, batata, café, } \\
\text { cenoura, cevada, citros, couve, feijão, fumo, milho, repolho, soja, tomate, } \\
\text { trigo e maçã. Alimentos para animais; feno, forragem, grãos, sorgo e } \\
\text { pastagens. Como isca formicida: aplicação para controle de cupim de } \\
\text { montículo. Aplicação no solo: nas culturas de batata e milho, no caso de } \\
\text { aplicação no solo, o intervalo de segurança não será determinado devido a } \\
\text { modalidade de uso. }\end{array}$ & \\
\hline $\begin{array}{l}\text { Resolução } \\
\text { RDC n. }{ }^{\circ} 135 \\
\text { de } 17 \text { de maio } \\
\text { de } 2002\end{array}$ & ANVISA & Agrotóxicos & $\begin{array}{l}\text { reavaliar os ingredientes ativos Dicofol, Heptacloro, MSMA, Linuron, } \\
\text { Captan, Folpet, Clorotalonil, Vinclozolin, Epoxiconazole, Procloraz, } \\
\text { Clorpirifós, com vistas à segurança alimentar e ocupacional, evitando } \\
\text { possíveis danos à saúde da população }\end{array}$ & ANVISA, 2002c. \\
\hline $\begin{array}{l}\text { Instrução } \\
\text { normativa } \mathrm{n}^{\mathrm{o}} \\
42 \text {, de } 05 \text { julho } \\
\text { de } 2002\end{array}$ & $\begin{array}{l}\text { MAPA - Séc. de } \\
\text { Defesa } \\
\text { Agropecuária }\end{array}$ & $\begin{array}{l}\text { Agrotóxicos, seus } \\
\text { componentes e afins }\end{array}$ & $\begin{array}{l}\text { Adotar, para efeito de atualização das bulas de agrotóxicos e afins com } \\
\text { finalidade fitossanitária, os nomes vulgares e científicos atualizados de } \\
\text { pragas, constantes do Anexo desta Instrução Normativa. }\end{array}$ & \\
\hline $\begin{array}{l}\text { Resolução RE } \\
n^{\circ} 74 \text {, de } 21 \text { de } \\
\text { julho de } 2002\end{array}$ & ANVISA & Metamidofós & $\begin{array}{l}\text { Altera a monografia do METAMIDOFÓS. Reavaliação concluída em abril } \\
\text { de } 2002\end{array}$ & \\
\hline Instrução & MAPA - Séc. de & Agrotóxicos, & Determinar às empresas titulares de registros de agrotóxicos a retirada das & MAPA, 2002. \\
\hline
\end{tabular}




\begin{tabular}{|c|c|c|c|c|}
\hline $\begin{array}{l}\text { Instrumento } \\
\text { Legal }\end{array}$ & $\begin{array}{l}\text { Órgão(s) } \\
\text { Envolvido(s) na } \\
\text { Aplicação } \\
\end{array}$ & $\begin{array}{c}\text { Substâncias } \\
\text { Químicas envolvidas }\end{array}$ & Objetivo da Legislação & Referência \\
\hline $\begin{array}{l}\text { Normativa } \mathrm{n}^{\circ} \\
46 \text {, de } 24 \text { de } \\
\text { julho de } 2002\end{array}$ & $\begin{array}{l}\text { Defesa } \\
\text { Agropecuária }\end{array}$ & componentes e afins & $\begin{array}{l}\text { indicações de misturas em tanque dos rótulos e bulas de seus agrotóxicos, } \\
\text { considerando que as recomendações técnicas de misturas em tanque de } \\
\text { agrotóxicos deverão ser avaliadas nos aspectos de agricultura, de saúde } \\
\text { pública e de meio ambiente. }\end{array}$ & \\
\hline $\begin{array}{l}\text { Instrução } \\
\text { Normativa } \\
\text { Interministerial } \\
n^{\circ} 49 \text { de } 20 \text { de } \\
\text { agosto de } 2002 \\
\end{array}$ & $\begin{array}{l}\text { MAPA, MMA, } \\
\text { MS }\end{array}$ & $\begin{array}{l}\text { Agrotóxicos seus } \\
\text { componentes e afins }\end{array}$ & $\begin{array}{l}\text { Dispõe que a avaliação, para fins de obtenção do registro de produto } \\
\text { técnico equivalente, será realizada com observância aos critérios constantes } \\
\text { do Anexo. }\end{array}$ & BRASIL, 2002b. \\
\hline 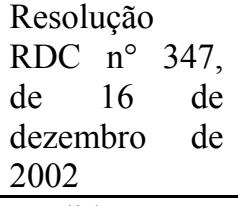 & ANVISA & $\begin{array}{l}\text { Agrotóxicos } \\
\text { preservantes } \\
\text { madeira }\end{array}$ & $\begin{array}{l}\text { Determina a publicação da relação de monografias dos ingredientes ativos } \\
\text { de agrotóxicos e preservantes de madeira, e dá outras providências. }\end{array}$ & \\
\hline $\begin{array}{ll}\text { Medida } & \\
\text { Provisória } & \mathrm{n}^{\mathrm{o}} \\
69, \text { de } 26 & \mathrm{de} \\
\text { setembro } & \mathrm{de} \\
2002 & \end{array}$ & - & $\begin{array}{l}\text { Produtos } \\
\text { farmacêuticos de uso } \\
\text { humano e veterinário, } \\
\text { fertilizantes, } \\
\text { agrotóxicos seus } \\
\text { componentes e afins. }\end{array}$ & $\begin{array}{l}\text { Dispõe sobre a proteção de informação não divulgada submetida para } \\
\text { aprovação da comercialização de produtos e dá outras providências }\end{array}$ & \\
\hline $\begin{array}{l}\text { Lei } \mathrm{n}^{\mathrm{o}} \quad 10.603 \\
\text { de } 17 \quad \text { de } \\
\text { dezembro } \\
2002\end{array}$ & - & $\begin{array}{l}\text { Produtos } \\
\text { farmacêuticos de uso } \\
\text { humano e veterinário, } \\
\text { fertilizantes, } \\
\text { agrotóxicos seus } \\
\text { componentes e afins }\end{array}$ & Conversão da Medida Provisória nº 69, de 26 de setembro de 2002. & BRASIL, 2002c. \\
\hline 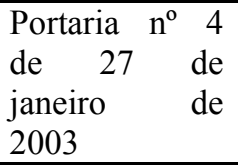 & MAPA & MIP & $\begin{array}{l}\text { Submete à consulta pública o Projeto de Instrução Normativa que disciplina } \\
\text { o Manejo Integrado de Pragas do Tomate, cultivado para uso industrial e } \\
\text { para consumo "in natura". }\end{array}$ & \\
\hline $\begin{array}{l}\text { Resolução } \\
\text { RDC } \mathrm{n}^{\circ} \quad 119 \\
\text { de } 19 \text { de maio }\end{array}$ & ANVISA & Agrotóxicos & $\begin{array}{l}\text { Cria o PROGRAMA de ANALISE de RESÍDUOS de AGROTÓXICOS } \\
\text { em ALIMENTOS - PARA }\end{array}$ & ANVISA, 2003. \\
\hline
\end{tabular}




\begin{tabular}{|c|c|c|c|c|}
\hline $\begin{array}{c}\text { Instrumento } \\
\text { Legal }\end{array}$ & $\begin{array}{l}\text { Órgão(s) } \\
\text { Envolvido(s) na } \\
\text { Aplicação } \\
\end{array}$ & $\begin{array}{c}\text { Substâncias } \\
\text { Químicas envolvidas }\end{array}$ & Objetivo da Legislação & Referência \\
\hline \multicolumn{5}{|l|}{ de 2003} \\
\hline $\begin{array}{l}\text { Resolução RE } \\
n^{\circ} 165 \text {, de } 29 \\
\text { de agosto de } \\
2003\end{array}$ & ANVISA & Agrotóxicos & $\begin{array}{l}\text { Determina a publicação do "Índice das monografias dos ingredientes ativos } \\
\text { de agrotóxicos, domissanitários e preservantes de madeira", cujo emprego } \\
\text { encontra-se autorizado conforme descrito na monografia. Revoga a Portaria } \\
\mathrm{n}^{\circ} 10 \text {, de } 8 \text { de março de } 1985\end{array}$ & \\
\hline $\begin{array}{l}\text { Portaria } \mathrm{n}^{\mathrm{o}} \\
518 \text {, de } 25 \mathrm{de} \\
\text { março de } 2004\end{array}$ & MS & Agrotóxicos & $\begin{array}{l}\text { Revoga a Portaria 1469/2000. Estabelece os procedimentos e as } \\
\text { responsabilidades relativas ao controle e vigilância da qualidade da água } \\
\text { para consumo humano e seu padrão de potabilidade, e dá outras } \\
\text { providências. } \\
\text { Foram mantidos os mesmos padrões de potabilidade para agrotóxicos } \\
\text { (valores em } \mu \mathrm{g} / \mathrm{L} \text { ): Alaclor 20,0; Aldrin e Dieldrin 0,03; Atrazina 2; } \\
\text { Bentazona 300; Clordano (isômeros) } 0,2 ; 2,4 \text { D 30; DDT (isômeros) 2; } \\
\text { Endossulfan 20; Endrin 0,6; Glifosato 500; Heptacloro e Heptacloro } \\
\text { epóxido 0,03; Hexaclorobenzeno 1; Lindano (g-BHC) 2; Metolacloro 10; } \\
\text { Metoxicloro 20; Molinato 6; Pendimetalina 20; Pentaclorofenol 9; } \\
\text { Permetrina 20; Propanil 20; Simazina 2; Trifluralina 20 }\end{array}$ & MS, 2004. \\
\hline $\begin{array}{l}\text { Resolução RE } \\
\mathrm{n}^{\circ} 86, \text { de } 23 \text { de } \\
\text { abril de } 2004\end{array}$ & ANVISA & Carbendazim & $\begin{array}{l}\text { Altera a monografia do ingrediente ativo Carbendazim, publicada na } \\
\text { Resolução RE } \mathrm{n}^{\circ} 165,29 / 8 / 2003 \text {, para os } \mathrm{LMRs} \text { das culturas de citros, } \\
\text { feijão e soja, que passam a ser } 5,0 ; 2,0 \text { e } 0,5 \mathrm{mg} / \mathrm{kg} \text {, respectivamente; inclui } \\
\text { a observação "Para fins de monitoramento de resíduos, devem ser } \\
\text { considerados os LMRs estabelecidos nas monografias de CARBENDAZIM } \\
\text { e TIOFANATO-METÍLICO, cujos resíduos são expressos como } \\
\text { CARBENDAZIM". }\end{array}$ & \\
\hline $\begin{array}{l}\text { Resolução RE } \\
n^{\circ} 85 \text {, de } 23 \text { de } \\
\text { abril de } 2004\end{array}$ & ANVISA & Tiofanato Metílico & $\begin{array}{l}\text { Altera a monografia do ingrediente ativo Tiofanato Metílico, publicada na } \\
\text { Resolução RE } \mathrm{n}^{\circ} 165,29 / 8 / 2003 \text {. Determina que para fins de } \\
\text { monitoramento de resíduos, devem ser considerados os LMRs } \\
\text { estabelecidos nas monografias de CARBENDAZIM e TIOFANATO- } \\
\text { METÍLICO, cujos resíduos são expressos como CARBENDAZIM". }\end{array}$ & \\
\hline $\begin{array}{l}\text { Resolução RE } \\
\mathrm{n}^{\circ} 87 \text {, de } 26 \text { de } \\
\text { abril de } 2004\end{array}$ & ANVISA & Agrotóxicos & $\begin{array}{l}\text { Estabelece o prazo de } 120 \text { dias, após a aprovação da ANVISA, para os } \\
\text { registrantes de produtos agrotóxicos adequarem as informações nos rótulos } \\
\text { e bulas. Revoga o Art. } 3^{\circ} \text {, da Resolução RE } n^{\circ} 165 \text {, de } 29 \text { de agosto de } \\
2003 \text {. }\end{array}$ & \\
\hline
\end{tabular}




\begin{tabular}{|l|l|l|l|l|}
\hline $\begin{array}{l}\text { Instrumento } \\
\text { Legal }\end{array}$ & $\begin{array}{c}\text { Órgão(s) } \\
\text { Envolvido(s) na } \\
\text { Aplicação }\end{array}$ & $\begin{array}{c}\text { Substâncias } \\
\text { Químicas envolvidas }\end{array}$ & \multicolumn{1}{|c|}{ Objetivo da Legislação } & Referência \\
\hline $\begin{array}{l}\text { Brasil. Decreto } \\
\text { Legislativo n } \\
197 \text { de 7 de } \\
\text { maio de 2004. }\end{array}$ & Brasil & Substâncias PIC & $\begin{array}{l}\text { Aprova o texto da Convenção sobre Procedimento de Consentimento } \\
\text { Prévio Informado para o Comércio Internacional de Certas Substâncias } \\
\text { Químicas e Agrotóxicos Perigosos, adotada em 10 de setembro de 1998, na } \\
\text { cidade de Roterdã. }\end{array}$ & BRASIL, 2004 \\
\hline $\begin{array}{l}\text { Brasil. Decreto } \\
\text { Legislativo n } \mathrm{n}^{\circ} \\
\text { 204, de 7 de } \\
\text { maio de 2004. }\end{array}$ & Brasil & Substâncias POPs & $\begin{array}{l}\text { Aprova o texto da Convenção de Estocolmo sobre Poluentes Orgânicos } \\
\text { Persistentes, adotada, naquela cidade, em 22 de maio de 2001. }\end{array}$ & BRASIL, 2004. \\
\hline
\end{tabular}

